INSTITUTO DE PESQUISAS ENERGÉTICAS E NUCLEARES

Autarquia associada à Universidade de São Paulo

IMPLANTES POROSOS À BASE DE TITÂNIO, AVALIAÇÃO IN VITRO E IN VIVO

TAMIYE SIMONE GOIA

Tese apresentada como parte dos requisitos para a obtenção do Grau de Doutor em Ciências na área de Tecnologia Nuclear Materiais.

Orientadora:

Drª . Ana Helena de Almeida Bressiani

SÃO PAULO

2013 
"And in the end, it's not the years in your life that count.

It's the life in your years." 
Agradecimentos

Ao Kalan, pela sua perspicácia como pesquisador, pela sua sabedoria como marido pela sua paciência como companheiro, pelo seu amor como melhor amigo, agradeço durante todo este trabalho e em nossas vidas. 
Agradecimentos

Aos meus Pais, Marcos e Matsumi por apoiarem minhas decisões, acreditando em minha competência profissional.

Aos meus sogros, Marco e Eunice por me acolherem de forma tão carinhosa e generosa. 


\section{AGRADECIMENTOS}

Ao programa de Pós-graduação do Instituto de Pesquisas Energéticas e Nucleares - IPEN, instrumentos de minha formação acadêmica e ao Conselho Nacional de Ensino e Pesquisa (CNPq), pela concessão da bolsa de doutorado.

À Prof ${ }^{\mathrm{a}} \mathrm{Dr}^{\mathrm{a}}$. Ana Helena de Almeida Bressiani minha orientadora, pela sua compreensão em todos os momentos dessa jornada, sendo sempre motivo da minha admiração e, sobretudo respeito. Obrigada pelos inúmeros exemplos de conduta nos quais tenho me espelhado na tentativa de sempre melhorar.

Ao Prof. Dr. José Carlos Bressiani pelo incentivo, colaboração e amizade durante o período de pós-graduação no IPEN.

Ao Dr. Hidetoshi, por ter acompanhado o desenvolvimento deste trabalho e pelas valiosas sugestões para a consolidação deste doutorado.

À Profá. Drª . Olga Higa pelos ensinamentos, discussões dos ensaios in vitro e carinho adquirido por todos esses anos, e ao Centro de Biotecnologia com a cooperação da $\mathrm{Dr}^{\mathrm{a}}$. Nanci, Dr ${ }^{\mathrm{a}}$. Andrea e MSc. Tatiana.

Ao Dr. Marcelo e ao Dr. Sérgio, pelas grandiosas contribuições no exame de qualificação e seminário de área.

Aos pessoal do CCTM Nildemar, Glauson, Celso, Flávia, Renê, Edson, Pedro, Olandir pela extrema dedicação nas análises solicitadas, pelo suporte e amizade.

À amiga Drª̣. Carola pela inestimável amizade, compreensão, carinho e respeito.

Às amigas $\mathrm{Dr}^{\mathrm{a}}$. Karolina e Drª . Vânia, que participaram direta e indiretamente neste trabalho, porém ativamente na minha vida, com apoio e amizade.

Às amigas $\mathrm{Dr}^{\mathrm{a}}$. Christiane e $\mathrm{Dr}^{\mathrm{a}}$. Deiby que me acolheram no grupo de biomateriais e tiveram papeis fundamentais para meu desenvolvimento na pesquisa. $O$ carinho e a amizade consolidaram nossa relação no trabalho e na vida. 
Aos amigos do IPEN, principalmente Dr. Márcio, Rodrigo, Roberta, Nara, Thais, Marcos e Dr ${ }^{\mathrm{a}}$. Heveline, que conviveram neste período impar de minha vida acadêmica.

À todos os meus familiares e aqueles que de alguma forma apoiaram a realização deste trabalho.

Aos membros da banca por aceitarem participar da avaliação deste trabalho.

Às pessoas que de alguma forma me ajudaram e que por um lapso de memória não agradeci nominalmente aqui. 
Resumo

\title{
IMPLANTES POROSOS À BASE DE TITÂNIO, AVALIAÇÃO IN VITRO E IN VIVO
}

\author{
Tamiye Simone Goia
}

\section{RESUMO}

O desenvolvimento de biomateriais com estrutura porosa visa permitir uma boa ancoragem biológica através do crescimento do tecido ósseo no interior dos poros, além de no caso de algumas ligas de titânio, proporcionar valores de módulo elástico semelhantes ao do osso, prevenindo assim o insucesso por reabsorção óssea na interface com o implante. O objetivo deste estudo foi avaliar o processamento de implantes porosos à base de titânio produzidos por metalurgia do pó, utilizando polímeros naturais como aditivos (albumina, amidos de arroz, batata, milho e a gelatina), e analisar a osteointegração desses implantes por ensaio in vivo. Foram obtidas, amostras de titânio comercialmente puro (Ticp) e da Liga Ti-13Nb-13Zr pelos processos de "spaceholder" e suspensão; os polímeros naturais foram removidos termicamente $\left(350^{\circ} \mathrm{C} / 1 \mathrm{~h}\right)$ previamente a sinterização $\left(1300^{\circ} \mathrm{C} / 1 \mathrm{~h}\right.$ e $1300^{\circ} \mathrm{C} / 3 \mathrm{~h}$, respectivamente). As metodologias de processamento utilizando aditivos de baixo custo propiciaram a obtenção de implantes metálicos porosos de maneira simplificada, com porosidades diferenciadas, boa homogeneidade estrutural, grau de porosidade adequado (entre 40\% e 60\%), distribuição e tamanho dos poros conforme o polímero natural formador. Na caracterização biológica, o teste in vitro de citotoxicidade validou a utilização dos implantes para a realização do teste in vivo. A avaliação da osteointegração foi realizada em coelhos da raça "New Zealand" em períodos de 49 dias. $\mathrm{Na}$ análise histológica por microscopia eletrônica de varredura e fluorescência, foram obtidos os resultados quantitativos e qualitativos da osteointegração, com crescimento ósseo em todos os implantes, apresentando osteocondutividade. Os melhores resultados ocorreram em implantes com porosidade homogênea, e com tamanho médio de poros entre 100 e $200 \mu \mathrm{m}$. Assim, os materiais porosos de titânio e da liga Ti-13Nb-13Zr produzidos com os polímeros naturais (amido de arroz, amido de batata, amido de milho, gelatina e albumina), permitiram a nutrição e manutenção necessárias para a sobrevivência das células, comprovando a osteointegração e osteocondução dos implantes desenvolvidos. 


\title{
TITANIUM BASED POROUS IMPLANTS, IN VITRO AND IN VIVO EVALUATION
}

\author{
Tamiye Simone Goia
}

\begin{abstract}
The development of biomaterials with porous structure, seeks to allow a good biological anchorage through bone tissue ingrowth within the pores, besides to propitiate elastic modulus values similar to bone, thus preventing the failure by bone resorption, on implant's interface. The goals of this study was to evaluate the processing of titanium based porous implants by powder metallurgy (PM), using natural polymers as additive (rice, potato and corn starches, albumin and gelatin), and evaluate these implants osseointegration by in vivo assay. Samples were obtained of commercially pure titanium (cpTi) and Ti-13Nb-13Zr alloy by space-holder and suspension techniques; the natural polymers were removed by thermal treatment $\left(350^{\circ} \mathrm{C} / 1 \mathrm{~h}\right)$ prior to sintering $\left(1300^{\circ} \mathrm{C} / 1 \mathrm{~h}\right.$ and $1300^{\circ} \mathrm{C} / 3 \mathrm{~h}$ respectively). The processing methodologies using low cost additives propitiate the production of porous metallic implants in a simplified manner, with differentiated porosities, good structural homogeneity, proper porosity degree (between $40 \%$ and $60 \%$ ), distribution and pore size as the related natural polymer. The biological characterization was first performed in vitro with a cytotoxicity test, which allowed the use of implants in vivo. The osseointegration evaluation was performed in New Zealand White rabbits for 49 days period. Histological analyses with scanning electron microscopy and fluorescence microscopy were obtained quantitative and qualitative results of osseointegration, with bone growth in all implants, presenting osteoconductivity. The best results were in implants with homogenous porosity and with mean pore size between 100 and $200 \mu \mathrm{m}$. Thus, titanium and $\mathrm{Ti}-13 \mathrm{Nb}-13 \mathrm{Zr}$ alloy porous materials produced with natural polymers (rice, potato and corn starches, albumin and gelatin), allowed the nutrition and nourishing needed to bone cells survival, proving the osseointegration and osteoconduction features of developed implants.
\end{abstract}




\section{SUMÁRIO}

Página

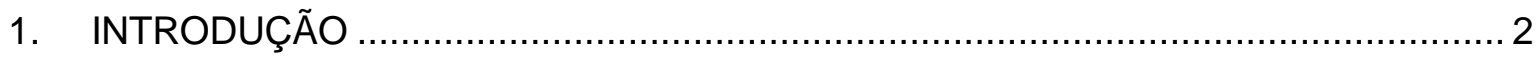

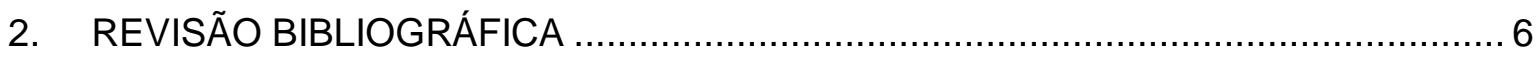

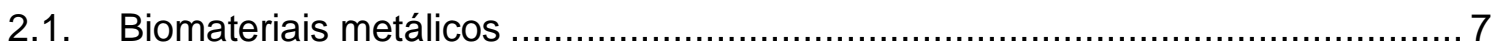

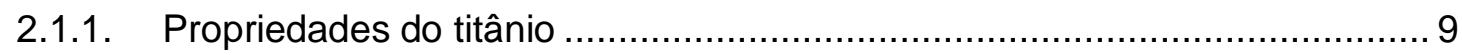

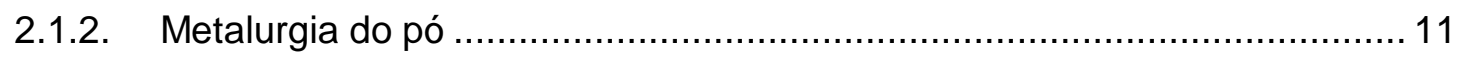

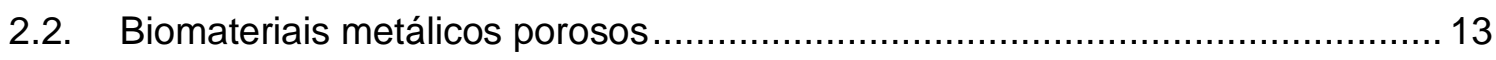

2.3. Interação entre metal e tecido ósseo........................................................... 21

2.4. Características dos poros na osteointegração............................................. 22

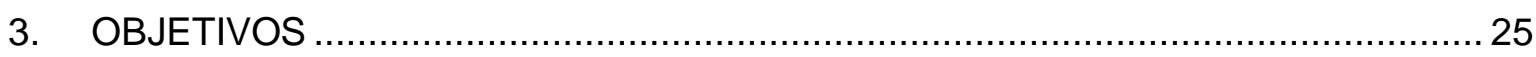

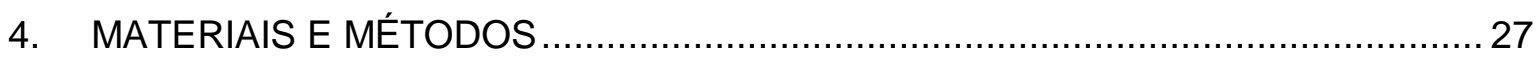

4.1. Caracterização do material particulado …...................................................... 27

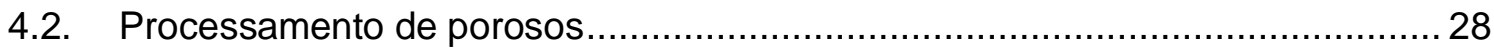

4.3. Caracterização física das amostras sinterizadas ....................................... 29

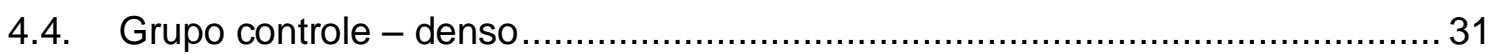

4.5. Caracterização biológica das amostras sinterizadas .................................... 32

4.5.1. Ensaio in vitro - teste de citotoxicidade............................................. 32

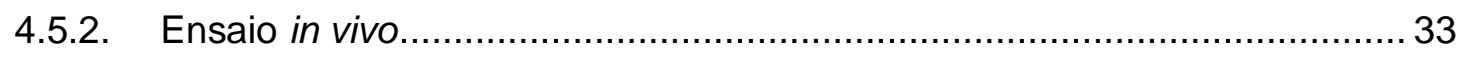

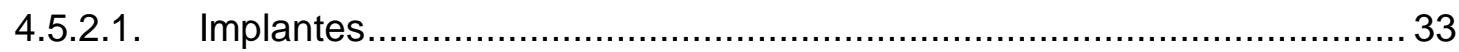

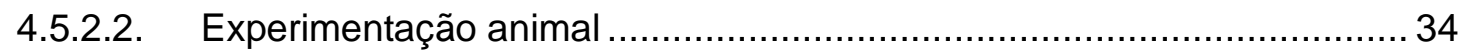

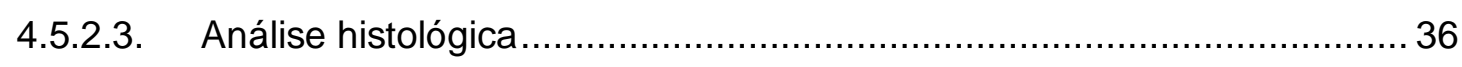

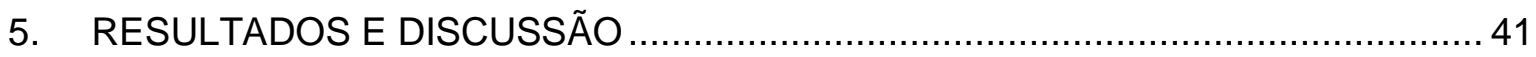

5.1. Caracterização do material particulado ...................................................... 41

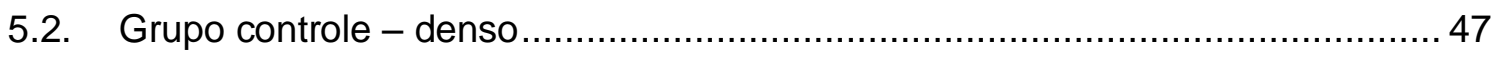

5.3. Metodologia para obtenção dos materiais porosos à base de titânio ................. 50

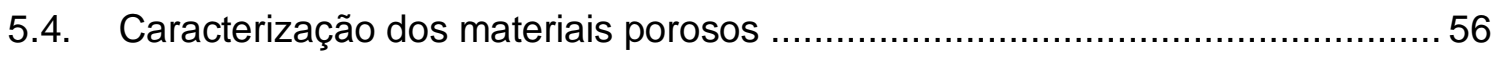

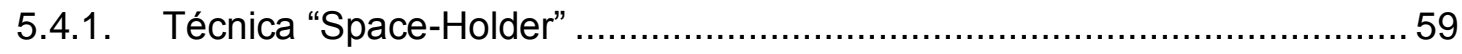

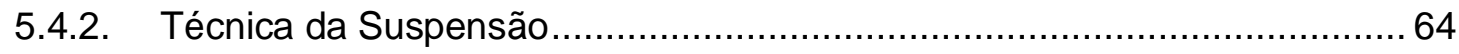




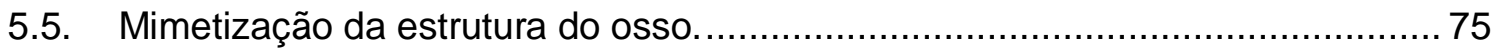

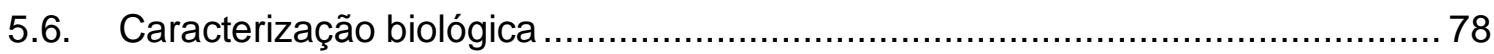

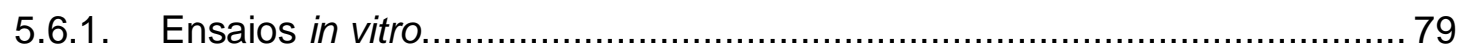

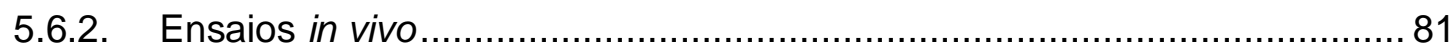

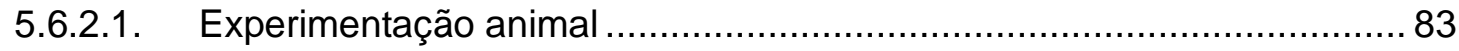

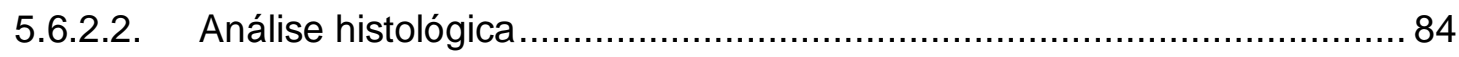

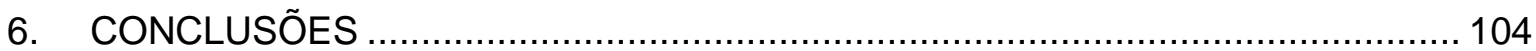

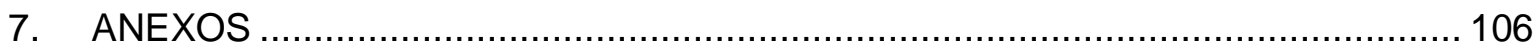

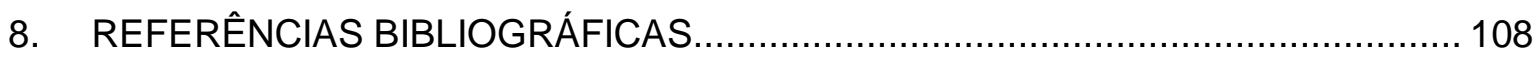




\section{LISTA DE FIGURAS}

Figura 1. Variadas formas de pós metálicos: A) esférico, B) arredondado, C) angular, D) irregular, E) poligonal, F) esponjoso ${ }^{56}$.

Figura 2. Processo de sinterização, principais estágios: A) pó solto, B) estágio inicial, C) estágio intermediário, D) estágio final ${ }^{54}$ 13

Figura 3. Poros obtidos por "space-holder", MEV da superfície após a sinterização ${ }^{61} \ldots 14$

Figura 4. Secção dos "scaffolds" produzidos por metalurgia do pó associado à uréia: à esquerda o titânio totalmente poroso, à direita o núcleo denso com superfície porosa ${ }^{62}$

Figura 5. Formação de pescoço entre as partículas esféricas. Secção transversal de implante obtido por sinterização por descarga-elétrica ${ }^{64}$.

Figura 6. Poros formados pela técnica de $\mathrm{MIM}^{24}$

Figura 7. MEV das amostras produzidas por adição de canfeno: à esquerda endurecida por 1 dia, à direita endurecida por 7 dias ${ }^{68}$

Figura 8. À esquerda, grande poros radialmente orientados observados à olho nu de uma secção da amostra. À direita, MEV de uma amostra seccionada com 44,6\% de porosidade ${ }^{70}$.

Figura 9. Presença de microporos nas paredes dos macroporos ${ }^{71}$

Figura 10. Micrografia de MEV mostrando a arquitetura de estrutura porosa obtida de replicação de esponja polimérica, após sinterização ${ }^{18}$.

Figura 11. Disco poroso produzido por FFE com $76 \%$ de porosidade, e MEV da superfície 26

Figura 12. Fluxograma do processamento de porosos.

Figura 13. Mensuração da área porosa pela utilização do programa ImagePro Plus: A) exemplificação da mensuração de uma amostra densa de Ticp com 5\% de porosidade, B) exemplificação da mensuração de uma amostra porosa de Ticp com adição de amido de arroz, com 47\% de porosidade.

Figura 14. Etapas do procedimento cirúrgico: A) acesso cirúrgico ao osso, B) perfurações com broca trefina, C) colocação dos implantes. 
Figura 15. Etapas do procedimento cirúrgico: A) sutura do periósteo previamente à sutura em pele, B) curativo no pós-operatório.

Figura 16. Representação esquemática do corte histológico.

Figura 17. Exemplo de análise em MEV/EDS de amostra do grupo de Ticp: A) imagem composta marcando Ti, Ca e P; B) imagem marcando somente áreas com Ti;

C) marcação de Ca; D) marcação de P. 38

Figura 18. Exemplo de análise em MEV/EDS de amostras do grupo de Liga: A) imagem composta marcando $\mathrm{Ca}, \mathrm{P}$; Ti, Nb e Zr; B) marcação de Ca; C) marcação de $\mathrm{P}$; D) marcação de Ti; E) marcação de Nb e F) marcação de Zr.

Figura 19. Exemplo de análise de imagem quantitativa da relação osso/implante: A) demarcação de osso, B) demarcação de poros e C) demarcação de implante.

Figura 20. Pó de $\mathrm{TiH}_{2}$ : A) MEV mostrando a morfologia bastante irregular das partículas com ângulos vivos; B) DRX constatando apenas a fase cristalina cúbica de face centrada

Figura 21. Pó de Ti: A) MEV mostrando a morfologia bastante irregular das partículas com elevada rugosidade; B) DRX constatando apenas a fase cristalina hexagonal compacta.

Figura 22. Pó do $\mathrm{Nb}$ : A) MEV mostrando a morfologia bastante irregular das partículas com ângulos vivos; B) DRX constatando apenas a fase cristalina cúbica de corpo centrado.

Figura 23. Pó do Zr: A) MEV mostrando a morfologia próxima do formato esférico; B) DRX constatando apenas a fase cristalina hexagonal compacta.

Figura 24. Distribuição do tamanho de partícula dos pós de partida: $\mathrm{TiH}_{2}(43 \mu \mathrm{m}), \mathrm{Ti}(120$ $\mu \mathrm{m}), \mathrm{Nb}(36 \mu \mathrm{m})$ e $\mathrm{Zr}(5,5 \mu \mathrm{m})$.

Figura 25. Desenho esquemático do processo de remoção do material orgânico sob forma de $\mathrm{CO}_{2}$ durante tratamento térmico em atmosfera oxidante.

Figura 26. Análise termogravimétrica (TG) e derivada (DTG) dos materiais particulados: A) $\mathrm{Ti}$, B) $\mathrm{TiH}_{2}$, C) $\mathrm{Nb}$ e D) $\mathrm{Zr}$. 
Figura 27. Análise termogravimétrica (TG) e derivada (DTG) dos polímeros naturais: A) amido de arroz, B) amido de milho, C) amido de batata, D) gelatina e E) albumina.

Figura 28. Distribuição do tamanho de partícula dos polímeros naturais: amidos de arroz $(11 \mu \mathrm{m})$, amido de milho $(16 \mu \mathrm{m})$, amido de batata $(55 \mu \mathrm{m})$, albumina $(45 \mu \mathrm{m}) \mathrm{e}$ gelatina $(225 \mu \mathrm{m})$.

Figura 29. MEV da superfície do implante denso: A) topografia após sinterização, B) e C) topografia após usinagem do implante denso.

Figura 30. MEV da microestrutura da secção transversal e polida da amostra de Ticp denso: A) observa-se a homogeneidade na distribuição dos poros na microestrutura, B) poros com formato esférico.

Figura 31. MEV da microestrutura da secção transversal e polida da amostra da Liga densa: A) observa-se a homogeneidade na distribuição dos poros na microestrutura, B) poros com formato alongado e arredondado. 49

Figura 32. DRX das amostras densas: A) Ticp, presença apenas da fase $\alpha$; B) Liga, presenças das fases $\alpha$ e $\beta$.

Figura 33. Amostra com adição de $30 \%$ em peso de amido de milho, pela técnica "SpaceHolder”: A) amostra após prensagem, B) amostra após tratamento térmico. . 50

Figura 34. Perda de massa (em \%) das amostras obtidas por "space-holder" após tratamento térmico e sinterização, em relação ao peso inicial das amostras. 51

Figura 35. Gráfico relacionando a pressão aplicada (MPa) e porosidade (\%) das amostras com adições de albumina, pela técnica "Space-Holder".

Figura 36. Amostra sinterizada porosa com adição de 30\% de albumina, prensada à 148 MPa: A) imagem macroscópica, diâmetro da amostra 5mm; B) microscopia óptica.

Figura 37. Perda de massa (\%) das amostras obtidas por suspensão após tratamento térmico e sinterização.

Figura 38. Porosidade (\%) das amostras acrescidas de 8 e $16 \%$ de polímeros naturais pela técnica da suspensão 
Figura 39. Amostra sinterizada com adição de amido de arroz 16\% em suspensão: A) imagem macroscópica, diâmetro da amostra $\sim 5 \mathrm{~mm}$; B) microscopia óptica. . 55

Figura 40. Amostra sinterizada com adição de amido de batata 16\% em suspensão: A) imagem macroscópica, diâmetro da amostra $\sim 5 \mathrm{~mm}$; B) microscopia óptica. . 55

Figura 41. Amostra sinterizada com adição de amido de milho 16\% em suspensão: A) imagem macroscópica, diâmetro da amostra $\sim 5 \mathrm{~mm}$; B) microscopia óptica. . 55

Figura 42. Amostra sinterizada com adição de gelatina 16\% em suspensão: A) imagem macroscópica, diâmetro da amostra $\sim 5 \mathrm{~mm}$; B) microscopia óptica.

Figura 43. Comparação entre as técnicas para determinação da porosidade para amostras de Ticp (A) e Liga (B). 57

Figura 44. Valores porcentuais de porosidade aparente.

Figura 45. Gráfico de rugosidade.

Figura 46. MEV da amostra de Ticp poroso com adição de 30\% de albumina: A) visualização da rugosidade da amostra, B), topografia após sinterização. MEV da microestrutura da secção transversal e polida:C) poros homogeneamente distribuídos na microestrutura, D) irregularidade no formato dos poros. 60

Figura 47. MEV da amostra da Liga porosa com adição de 30\% de albumina: A) visualização da rugosidade da amostra, B) topografia após sinterização. MEV da microestrutura da secção transversal e polida:C) poros homogeneamente distribuídos na microestrutura, D) irregularidade no formato dos poros.

Figura 48. DRX das amostras porosas com adição de 30\% de albumina: A) Ticp, presença da fase $\alpha$ e fase TiO; B) Liga, presenças das fases $\alpha$ e $\beta$, e fase TiO.

Figura 49. DRX das amostras do grupo poroso de Ticp com adições de: gelatina, amido de batata, amido de milho, amido de arroz e o controle denso. Presença apenas da fase $\alpha$.

Figura 50. MEV da superfície da amostra de Ticp poroso com adição de $16 \%$ de amido de arroz. A) visualização da rugosidade da amostra, B) topografia após sinterização. MEV da microestrutura da secção transversal e polida: C) poros heterogêneos distribuídos na microestrutura, D) irregularidade dos microporos. 
Figura 51. MEV da superfície da amostra de Ticp poroso com adição de 16\% de amido de milho. A) visualização da rugosidade da amostra, B) topografia após sinterização. MEV da microestrutura da secção transversal e polida: C) poros homogêneos distribuídos na microestrutura, D) irregularidade dos poros.

Figura 52. MEV da superfície da amostra de Ticp poroso com adição de $16 \%$ de amido de batata. A) visualização da rugosidade da amostra, B) topografia após sinterização. MEV da microestrutura da secção transversal e polida: C) poros distribuídos na microestrutura, D) irregularidade dos poros.

Figura 53. MEV da superfície da amostra de Ticp poroso com adição de $16 \%$ de gelatina. A) visualização da rugosidade da amostra, B) topografia após sinterização. MEV da microestrutura da secção transversal e polida: C) poros distribuídos na microestrutura, D) irregularidade dos poros.

Figura 54. Análise do tamanho de poros por análise de imagem, amostras de Ticp.

Figura 55. DRX das amostras do grupo poroso da Liga com adições de: gelatina, amido de batata, amido de milho, amido de arroz e o controle denso. Presença das fases $\alpha$ e $\beta$, e na amostra com adição de gelatina houve a formação da fase $\mathrm{TiO}$.

Figura 56. MEV da superfície da amostra de Liga porosa com adição de $16 \%$ de amido de arroz: A) visualização da rugosidade da amostra, B) topografia após sinterização. MEV da microestrutura: C) poros distribuídos na microestrutura, D) irregularidade dos poros.

Figura 57. MEV da superfície da amostra de Liga porosa com adição de $16 \%$ de amido de milho: A) visualização da rugosidade da amostra, B) topografia após sinterização. MEV da microestrutura: C) poros distribuídos na microestrutura, D) irregularidade dos poros.

Figura 58. MEV da superfície da amostra de Liga porosa com adição de $16 \%$ de amido de batata: A) visualização da rugosidade da amostra, B) topografia após sinterização. MEV da microestrutura: C) poros distribuídos na microestrutura, D) irregularidade dos poros. 73

Figura 59. MEV da superfície da amostra de Liga porosa com adição de 16\% de gelatina: A) visualização da rugosidade da amostra, B) topografia após sinterização. 
MEV da microestrutura: C) grandes áreas porosas na microestrutura, D) irregularidade dos poros.

Figura 60. Análise do tamanho de poros por análise de imagem, amostras da Liga. 75

Figura 61. MEV, microarquitetura do osso trabecular da tíbia proximal de coelho: A) região com poros heterogêneos, B) região com poros homogêneos. 76

Figura 62. Microarquiteturas das amostras com adição de albumina: A) Ticp, B) Liga.... 76

Figura 63. Microarquiteturas das amostras com adição de amido de arroz: A) Ticp, B) Liga.

Figura 64. Microarquiteturas das amostras com adição de amido de batata: A) Ticp, B) Liga.

Figura 65. Microarquiteturas das amostras com adição de amido de milho: A) Ticp, B) Liga.

Figura 66. Microarquiteturas das amostras com adição de gelatina: A) Ticp, B) Liga...... 78

Figura 67. Gráfico de avaliação da citotoxicidade das amostras sinterizadas: Ticp batata, Ticp arroz, Ticp albumina, Ticp gelatina e Ticp milho. Sendo o controle negativo Ticp denso e controle positivo solução fenol $0,3 \%$. 80

Figura 68. Gráfico de avaliação da citotoxicidade das amostras sinterizadas: Liga batata, Liga arroz, Liga albumina, Liga gelatina e Liga milho. Sendo o controle negativo Liga densa e controle positivo solução fenol $0,3 \%$.

Figura 69. Amostras osso-implante das tíbias: esquerda e direita. No centro da figura, duas radiografias referentes às amostras em dois planos distintos.

Figura 70. MEV do corte histológico representando a interação entre o osso e o implante poroso, os osteócitos estão indicados pelas setas: A) amostra Ticp com amido de arroz, B) amostra Ticp com amido de milho.

Figura 71. Implante de Ticp denso: A) MEV do corte histológico (montagem), observação da interação do osso e implante; B) Gráfico quantitativo relativo a figura C; C) MEV do corte histológico representando a interface osso e implante; D) EDS do corte histológico da imagem representada em C; E) Microscopia de fluorescência dos marcadores ósseos, interface osso e implante; F) MEV do corte histológico, observação da osteocondução pela superfície do implante.91 
Figura 72. Implante de Ticp obtida pela adição de amido de arroz: A) MEV do corte histológico, observação da interação do osso e implante; B) Gráfico quantitativo relativo as figuras $\mathrm{C}$ e $\mathrm{D}$; C) MEV do corte histológico representando áreas de poro, osso e implante; D) EDS do corte histológico da imagem representada em C; E) Microscopia de fluorescência dos marcadores ósseos, interface osso e implante; F) Microscopia de fluorescência dos marcadores ósseos, interior do implante.

Figura 73. Implante de Ticp obtida pela adição de amido de batata: A) MEV do corte histológico (montagem), observação da interação do osso e implante; B) Gráfico quantitativo relativo as figuras C e D; C) MEV do corte histológico representando áreas de poro, osso e implante; D) EDS do corte histológico da imagem representada em C; E) Microscopia de fluorescência dos marcadores ósseos, interface osso e implante; F) Microscopia de fluorescência dos marcadores ósseos, interior do implante.

Figura 74. Implante de Ticp obtida pela adição de amido de milho: A) MEV do corte histológico (montagem), observação da interação do osso e implante; B) Gráfico quantitativo relativo as figuras C e D; C) MEV do corte histológico representando áreas de poro, osso e implante; D) EDS do corte histológico da imagem representada em C; E) Microscopia de fluorescência dos marcadores ósseos, interface osso e implante; F) Microscopia de fluorescência dos marcadores ósseos, interior do implante. 94

Figura 75. Implante de Ticp obtida pela adição de gelatina: A) MEV do corte histológico (montagem), observação da interação do osso e implante; B) Gráfico quantitativo relativo as figuras $\mathrm{C}$ e $\mathrm{D} ; \mathrm{C}) \mathrm{MEV}$ do corte histológico representando áreas de poro, osso e implante; D) EDS do corte histológico da imagem representada em C; E) Microscopia de fluorescência dos marcadores ósseos, interface osso e implante; F) Microscopia de fluorescência dos marcadores ósseos, interior do implante. 95

Figura 76. Implante de Ticp obtida pela adição de albumina: A) MEV do corte histológico (montagem), observação da interação do osso e implante; B) Gráfico quantitativo relativo as figuras $\mathrm{C}$ e $\mathrm{D} ; \mathrm{C}) \mathrm{MEV}$ do corte histológico representando áreas de poro, osso e implante; D) EDS do corte histológico da imagem representada em C; E) Microscopia de fluorescência dos marcadores ósseos, interface osso e implante; F) Microscopia de fluorescência dos marcadores ósseos, interior do implante. 
Figura 77. Implante de Liga denso: A) MEV do corte histológico, observação da interação do osso e implante; B) Gráfico quantitativo relativo a figuras C; C) MEV do corte histológico representando áreas de interface osso e implante; D) EDS do corte histológico; E) Microscopia de fluorescência dos marcadores ósseos, interface osso e implante; F) Microscopia de fluorescência dos marcadores ósseos, interior do implante.

Figura 78. Implante de Liga obtida pela adição de amido de arroz: A) MEV do corte histológico (montagem), observação da interação do osso e implante; B) Gráfico quantitativo relativo as figuras C e D; C) MEV do corte histológico representando áreas de poro, osso e implante; D) EDS do corte histológico da imagem representada em C; E) Microscopia de fluorescência dos marcadores ósseos, interface osso e implante; F) Microscopia de fluorescência dos marcadores ósseos, interior do implante.

Figura 79. Implante de Liga obtida pela adição de amido de batata: A) MEV do corte histológico (montagem), observação da interação do osso e implante; B) Gráfico quantitativo relativo as figuras $\mathrm{C}$ e D; C) MEV do corte histológico representando áreas de poro, osso e implante; D) EDS do corte histológico da imagem representada em C; E) Microscopia de fluorescência dos marcadores ósseos, interface osso e implante; F) Microscopia de fluorescência dos marcadores ósseos, interior do implante. 99

Figura 80. Implante de Liga obtida pela adição de amido de milho: A) MEV do corte histológico (montagem), observação da interação do osso e implante; B) Gráfico quantitativo relativo as figuras C e D; C) MEV do corte histológico representando áreas de poro, osso e implante; D) EDS do corte histológico da imagem representada em C; E) Microscopia de fluorescência dos marcadores ósseos, interface osso e implante; F) Microscopia de fluorescência dos marcadores ósseos, interior do implante. 100

Figura 81. Implante de Liga obtida pela adição de gelatina: A) MEV do corte histológico (montagem), observação da interação do osso e implante; B) Gráfico quantitativo relativo as figuras $\mathrm{C}$ e D; C) MEV do corte histológico representando áreas de poro, osso e implante; D) EDS do corte histológico da imagem representada em C; E) Microscopia de fluorescência dos marcadores ósseos, interface osso e implante; F) Microscopia de fluorescência dos marcadores ósseos, interior do implante. 
Figura 82. Implante de Liga obtida pela adição de albumina: A) MEV do corte histológico (montagem), observação da interação do osso e implante; B) Gráfico quantitativo relativo as figuras $\mathrm{C}$ e $\mathrm{D} ; \mathrm{C}) \mathrm{MEV}$ do corte histológico representando áreas de poro, osso e implante; D) EDS do corte histológico da imagem representada em C; E) Microscopia de fluorescência dos marcadores ósseos, interface osso e implante; F) Microscopia de fluorescência dos marcadores ósseos, interior do implante. 


\section{LISTA DE TABELAS}

Tabela 1. Tamanho de poro ideal relatado por cada autor. 22

Tabela 2. Porosidade das amostras produzidas por "Space-Holder". 52

Tabela 3. Técnicas de processamento e polímeros naturais utilizados. 56

Tabela 4. Densidade obtida por picnometria de hélio das amostras densas e porosas. .. 58

Tabela 5. Variações no processamento por metalurgia do pó e space-holder, resultando em diferentes tamanho de poros e porosidade. 63

Tabela 6. Análise qualitativa da intensidade de marcação fluorescente no interior dos implantes. 
O uso de biomateriais nas áreas médicas é necessário para tratar doenças e corrigir problemas de inúmeras origens. Nos ossos, os biomateriais são usados para estabilizar, preencher, substituir e restituir funções ósseas. Para esse fim biomateriais metálicos suprem as necessidades dos ossos e após osteointegração podem restabelecer o tecido ósseo plenamente. A falta de desenvolvimento tecnológico faz com que inúmeros problemas e doenças diferentes sejam tratados de uma mesma maneira, elevando taxas de insucesso e de substituição de próteses após implantação, gerando custos elevados aos sistemas de saúde. Esses custos podem ser minimizados melhorando o entendimento, e endereçando corretamente os problemas com as ferramentas adequadas. Assim, pesquisas multidisciplinares têm como propósito aumentar a taxa de sucesso dos implantes, visando o bem-estar do paciente. 


\section{INTRODUÇÃO}

O desenvolvimento de biomateriais envolve um estudo multidisciplinar bastante complexo, as causas relacionadas ao insucesso de próteses variam entre falhas mecânicas e humanas, e o não domínio de tecnologia nas várias áreas faz com que inúmeros problemas e doenças diferentes sejam tratados de uma mesma maneira, sem critério específico. A demanda por implantes endo-ósseos tem aumentado nos últimos anos devido ao aumento da expectativa de vida da população em geral, além de acidentes automotivos em crescimento substancial nos grandes centros urbanos. Biomateriais metálicos visam atender as necessidades de substituição, ou reparação, de tecidos (órgãos) perdidos e/ou lesionados, atendendo requisitos como biocompatibilidade (compatibilidade com o organismo) e biofuncionalidade (habilidade de suportar e transferir cargas) ${ }^{1,2}$. O titânio e suas ligas são amplamente utilizados como substitutos de tecido ósseo, entretanto existem problemas relacionados ao tempo de vida útil em função no organismo devido à qualidade da interface formada entre osso e implante. Materiais com estrutura porosa permitem uma ancoragem biológica dos tecidos circundantes através do crescimento ósseo no interior dos poros, além de proporcionar valores de módulo elástico equivalente ao do osso trabecular, prevenindo assim a reabsorção óssea na interface com o implante ${ }^{3,4}$.

O tecido ósseo é o principal responsável por fornecer ao organismo estabilidade e sustentação, sendo, desta maneira, o órgão receptor de todos os sistemas de implantes ortopédicos e dentais. Além de ser um tecido de sustentação altamente especializado, é capaz de modificar a sua própria arquitetura para atender a fatores físicos e hormonais. No processo de reparo, a cicatrização da interface osso/implante passa pelos mesmos estágios que uma fratura óssea direta, seguindo uma sequência ordenada de eventos. Após a estabilização primária, a cicatrização tem início com a formação de coágulo entre o osso e o implante, com subsequente organização do coágulo e células formando vasos sanguíneos. As células osteoprogenitoras proliferam-se neste meio organizado e diferenciam-se em osteoblastos, promovendo a deposição de osso na superfície do implante ${ }^{5,6,7}$.

A topografia do implante é um dos fatores que influencia o processo de reparação óssea. Embora implantes de superfície usinada tenham sido utilizados por muitos anos, estudos demonstram que o aumento na rugosidade tende a aumentar, não só a área de superfície entre o osso e o implante, mas também a resistência de união da interface ${ }^{8,9}$. 
Dentre as modificações topográficas existentes, a porosidade nos implantes é bastante interessante, pois permite a ocorrência do fenômeno de invasão tecidual no interior dos poros, "Bone Ingrowth" ${ }^{10}$. Os implantes porosos devem apresentar porosidade interconectada, com espaços que permitam a manutenção vascular necessária para a mineralização contínua do tecido ósseo. Desta maneira, tanto os poros, como os canais de interconexão, devem apresentar tamanho suficiente para a infiltração das células responsáveis pela formação da matriz tecidual no interior do material, objetivando atender os requisitos desejáveis para uma reabilitação duradoura ${ }^{11,12,13}$.

O titânio e suas ligas são os principais metais estudados para implantes porosos por suas excelentes propriedades mecânicas e interações biológicas. Pesquisas com titânio poroso vêm sendo realizadas com o objetivo de analisar questões relacionadas ao tamanho ideal de poros, grau de porosidade e a influência destes no aumento da resistência de união da interface osso-implante ${ }^{14}$. O tamanho do poro é uma questão abordada por muitos autores podendo direcionar a migração e maturação de células osteoprogenitoras. Alguns autores ainda determinam que a vascularização não ocorre em poros de diâmetro inferior a $100 \mu \mathrm{m}$, sendo o tamanho de poro adequado à reorganização óssea e vascularização reportado como ótimo no intervalo de 100-500 $\mu \mathrm{m}$ $10,12,13,15,16,17,18$

Métodos para produção de materiais metálicos porosos são baseados em metalurgia do pó (MP). Esta técnica permite a produção de peças com formato complexo e dimensões próximas às finais, "Near-net shape", evitando a etapa de usinagem ${ }^{14,19}$. A manipulação dos metais na forma de particulado permite a adição de elementos alcançando uma satisfatória homogeneidade estrutural, assim como formação de porosidade $20,21,22$. A produção de estruturas porosas tem sido proposta por vários métodos, tais como: "space-holder" ${ }^{22,23}$, moldagem por injeção de pós-metálicos (MIM) ${ }^{24}$, "freeze-cast" ${ }^{25}$, fusão por feixe de elétrons (FFE) ${ }^{26}$ e prototipagem ${ }^{27}$.

Polímeros naturais, como os amidos, são utilizados com sucesso na produção de peças cerâmicas porosas, e uma das propostas deste trabalho foi adaptar o processo para metais ${ }^{28,29}$. Pela técnica sacrificial ou "space-holder", o amido é removido por tratamento térmico formando poros nos espaços ocupados por ele, em se tratando de metais, a oxidação durante o tratamento térmico pode ser um empecilho podendo fragilizar a estrutura. Em relação à técnica do gelcasting ou suspensão, o amido tem a função de agente geleificante, absorvendo água e expandindo volumetricamente, ações importantes para a produção de poros na estrutura ${ }^{30}$. Outro polímero natural que pode ser aplicado como aditivo é a gelatina que é derivada do colágeno e apresenta propriedades de biocompatibilidade, biodegradabilidade e não toxicidade ${ }^{31}$. A albumina, 
proteína também utilizada para obtenção de cerâmicas porosas, apresenta características de biocompatibilidade e presença abundante no sistema biológico ${ }^{32}$. A capacidade de geleificação em suspensão e a degradabilidade desses polímeros naturais, deu motivação para este estudo aplicando técnicas normalmente utilizadas para materiais cerâmicos, visando a obtenção de implantes metálicos porosos. 
O conhecimento de diversas áreas correlatas ao tema "biomateriais" faz-se necessário, a fim de relacionar e explicar as possíveis interferências de materiais aloplásticos no sistema biológico. Neste capítulo é salientada a importância do conhecimento e entendimento da interação dos implantes metálicos com o tecido ósseo (responsável pelo suporte desses implantes). Outros fatores são destacados para dar maior embasamento teórico a este trabalho, referem-se à forma de obtenção de metais porosos, variações de processamento, bem como características que influenciam na melhoria da osteointegração. 


\section{REVISÃO BIBLIOGRÁFICA}

Para que os biomateriais possam entrar em contato com fluidos biológicos e tecidos vivos, eles devem preencher certos requisitos fundamentais, entre eles temos biocompatibilidade e biofuncionalidade. A biocompatibilidade representa a característica para que um material possa ser considerado adequado para uso como biomaterial, isto é, não provocar reações alérgicas ou inflamatórias exacerbadas, tóxicas ou carcinogênicas, sendo reconhecido pelo organismo e muitas vezes integrado ao tecido. Além da biocompatibilidade, existe a necessidade de restituir a função do tecido, o que requer ao material também apresentar 0 aspecto de biofuncionalidade ${ }^{33}$. Outros requisitos relevantes estão relacionados às propriedades mecânicas adequadas, material passível de esterilização e custo. Assim, a seleção de um biomaterial deve ter início com a identificação das propriedades necessárias para a recuperação do tecido e aplicação ${ }^{1,34}$.

Conforme os biomateriais foram sendo desenvolvidos, as perspectivas e necessidades foram mudando. $O$ objetivo durante a primeira geração de biomaterial foi de alcançar uma combinação adequada de propriedades físicas dos materiais para coincidir com as do tecido substituído, com uma resposta minimamente tóxica ao hospedeiro. Cirurgiões procuravam materiais inertes com propriedades mecânicas adequadas, resistência à corrosão e ausência de efeitos prejudiciais, tais como carcinogenicidade, toxicidade, alergia e inflamação. Na segunda metade do século XX, começaram as parcerias entre engenharias e medicina, para o desenvolvimento de biomateriais projetados especificamente para uso no corpo humano. Durante este período, foram criados biomateriais que promovessem respostas específicas dos tecidos circundantes, como os materiais bioativos. Outro avanço nesta segunda geração de biomateriais foi o desenvolvimento de materiais absorvíveis com controlada decomposição química e absorção pelo tecido ${ }^{35}$.

O sucesso clínico de implantes bioinertes, bioativos e absorvíveis é uma resposta vital para as necessidades médicas com o aumento do envelhecimento da população. No entanto, análises de sobrevida das próteses esqueléticas e válvulas cardíacas artificiais mostram que, um terço a metade das próteses falham após 10 a 25 anos, necessitando novas intervenções cirúrgicas em substituição a esses implantes ${ }^{35}$.

A interação entre biomateriais e organismos é bastante discutida na literatura, principalmente sobre materiais que induzem resposta mais complexa, como no caso dos 
materiais bioativos ${ }^{35}$. Os biomateriais metálicos, considerados de modo geral, inertes, são bastante estudados, assim como a interação com o tecido ósseo. As aplicações do titânio e suas ligas são bastante variadas, uma vez que são de grande interesse na área biomédica por apresentarem boas propriedades como resistência mecânica, tenacidade e conformabilidade; e quando na forma porosa apresentam vantagens, como, leveza, dureza, elevada área superficial e módulo elástico compatível do osso ${ }^{4}$.

O conceito de osteointegração é definido clinicamente como a estabilidade assintomática de um material aloplástico, conseguida e mantida no organismo sob carga funcional por longos períodos de tempo. Histologicamente este modo de ancoragem é traduzido, em observação sob microscopia de luz, como uma conexão direta estrutural e funcional entre o osso vivo organizado e a superfície que carrega a carga do implante sem a intervenção de tecido mole ${ }^{36,37}$. A revisão de literatura apresentada aqui está focada na concepção de biomateriais metálicos, mais especificamente titânio e suas ligas; nos principais métodos de obtenção de biomateriais metálicos porosos, e na interação entre o tecido ósseo e os implantes porosos.

\subsection{Biomateriais metálicos}

A substituição anatômica de partes do corpo, perdida ou danificada, tem relatos históricos desde a antiguidade egípcia, cujas próteses de madeira foram descobertas em múmias. A descrição mais antiga de uma prótese foi feita em 484 a.C, no relato de Heródoto, que conta sobre a amputação do pé de um soldado persa aprisionado pelo inimigo, e mais tarde a substituição por um membro de madeira. Próteses de ferro foram construídas para os soldados durante a ldade Média com os mesmos materiais que faziam as armaduras. No séc. XIX as próteses de madeira voltaram a ser utilizadas por serem mais leves do que as de metal, e algumas já com movimento articulado ${ }^{18}$.

As guerras tiveram grande influência no desenvolvimento desta área pelas inúmeras incidências de membros amputados. O governo americano, depois da Guerra Civil Americana, incentivou a pesquisa na área protética, ao mesmo tempo que a descoberta de anestésicos (como, clorofórmio e éter) permitiram a realização de cirurgias mais demoradas, pela possibilidade de preparar melhor os membros amputados para a colocação de próteses ${ }^{18}$.

No limiar do séc. XX foram realizados com sucesso implantes sintéticos na assistência a vítimas de fraturas. Depois da Segunda Guerra Mundial houve um grande avanço nos estudos da biomecânica do movimento humano, melhorando o "design" dos 
membros artificiais. Nos anos 60 e 70 foi desenvolvida a primeira geração de materiais para utilização no interior do corpo humano. Procuravam-se materiais inertes, que minimizassem a resposta negativa do corpo humano a esses objetos estranhos. Em meados dos anos 80 surgiu a segunda geração de materiais bioativos, como os biovidros, cerâmicas e compósitos, estes materiais foram utilizados em várias próteses ortopédicas e dentárias. A recuperação das funções fisiológicas dos órgãos internos é uma conquista recente na área médica ${ }^{35}$.

Com o envelhecimento da população e o elevado número de idosos, é observado o aumento das condições médicas que necessitam de intervenção com uso de biomateriais. Com isso, a demanda de biomateriais para produção de próteses, em particular para aplicação na substituição de tecidos duros danificados, como, próteses de quadril e implantes dentários, tende a aumentar ${ }^{18}$. Os implantes biomédicos são usados para resolver defeitos que não podem ser corrigidos pelo processo natural de reparo e regeneração. O sucesso de um implante ósseo requer materiais com características mecânicas e funcionais semelhantes as do tecido ósseo, de acordo com a aplicação para o qual é requerido ${ }^{38}$. A utilização de materiais artificiais para aplicações clínicas torna-se cada vez mais complexa e diversificada para cada caso ${ }^{34}$.

As propriedades e os requisitos são de fundamental importância para a escolha mais adequada de um biomaterial. A caracterização química, física, mecânica e biológica do material proporcionam o desenvolvimento e a viabilidade do uso. Biomaterial é definido como material concebido para estar em contato com sistemas biológicos com o objetivo de diagnosticar, tratar, aumentar ou substituir qualquer tecido, órgão ou função do corpo. Dentre os materiais usados encontram-se: metais (aços inoxidáveis, platina, ligas Co-Cr-Mo e titânio e suas ligas), cerâmicas (alumina, zircônia, hidroxiapatita, trifosfatos de cálcico, biovidros e vitrocerâmicas), polímeros sintéticos (poliuretanos e poliésteres) ou naturais (proteínas) e compósitos (resultado da combinação de alguns dos materiais anteriores) ${ }^{39}$.

Os materiais metálicos são principalmente usados na confecção de implantes devido a suas propriedades mecânicas, destacam-se: boa resistência mecânica e elevada tenacidade, facilidade de fabricação e baixo custo. Elementos metálicos, como, $\mathrm{Fe}, \mathrm{Cr}$, Co, Ni, Ti, Ta e Mo, são utilizados na confecção de implantes por serem tolerados pelo corpo, sendo alguns até essenciais para funções celulares ou metabólicas. Entretanto, em quantidades elevadas, as chances de ocorrer corrosão metálica em ambiente fisiológico altamente agressivo são aumentadas. O potencial de corrosão e os produtos de corrosão são os principais fatores que limitam o tipo de metal que pode ser 
empregado como biomaterial. A corrosão pode ainda levar à deterioração das propriedades mecânicas do material, comprometendo o desempenho da função ${ }^{1}$.

Biomateriais metálicos, como, os aços inoxidáveis, principalmente os austeníticos do tipo 316L (ASTM F138), ligas Co-Cr-Mo (ASTM F75, F799), Co-Ni-Cr-Mo (ASRM F562), titânio puro e Ti-6Al-4V (ASTM F67 e F136), são os mais usados em ortopedia, principalmente na confecção de próteses articuladas e ainda como elementos estruturais na fixação de fraturas nas osteossínteses ${ }^{1}$. O titânio e suas ligas são os que têm recebido maior atenção devido à sua vasta gama de aplicação, principalmente na ortopedia e odontologia $40,41,46$.

\subsubsection{Propriedades do titânio}

O titânio e suas ligas são particularmente adequados para o trabalho em ambiente corrosivo, ou para aplicações em que seja fundamental o seu baixo peso específico. Possui alta relação resistência-peso específico e propriedades não-magnéticas ${ }^{1}$. 0 titânio puro é um metal claro, brilhante e de boa ductilidade; possui densidade de 4,51 $\mathrm{g} / \mathrm{cm}^{3}$, ponto de fusão de $1668^{\circ} \mathrm{C}$ e sua ebulição ocorre a $3.260^{\circ} \mathrm{C}$. Apesar de ser o quarto elemento mais abundante da crosta terrestre, o custo para obtenção do metal puro é relativamente elevado devido à complexibilidade do processo de redução e purificação 42,48 .

O titânio tem elevada afinidade ao oxigênio, e quando em contato com a atmosfera em temperatura ambiente, forma imediatamente uma camada óxida na superfície, que podem variar de $\mathrm{TiO}$ a $\mathrm{Ti}_{7} \mathrm{O}_{12}{ }^{43}$. Essa camada é superficial, estável, contínua e aderente, conferindo ao titânio características como: alta resistência ao desgaste, resistência à corrosão e biocompatibilidade ${ }^{9,44}$. A afinidade do hidrogênio ao titânio pode ser observada pela absorção do hidrogênio quando em contato com vapor de água, ácidos, óleos e hidrocarbonetos, quando em altas temperaturas. Com concentrações acima de 125 a 200 ppm, o hidrogênio fragiliza algumas ligas de titânio, reduzindo a resistência ao impacto e causando fratura sem deformação plástica. Esta mesma propriedade permite a produção de pó de titânio pela técnica da hidrogenaçãodehidrogenação. No processo de hidrogenação, o titânio em condições de elevada temperatura, pressão e concentração de hidrogênio, permite que o mesmo entre nos interstícios da rede cristalina do metal, fragilizando-o e permitindo a quebra do material. A dehidrogenação do titânio ocorre a partir de $600^{\circ} \mathrm{C}$, quando o hidrogênio começa a sair do interstício da rede cristalina ${ }^{45}$. 
O titânio apresenta estrutura cristalina hexagonal compacta em temperatura ambiente, denominada fase alfa $(\alpha)$. Acima de $882^{\circ} \mathrm{C}$, a estrutura cristalina mais estável é cúbica de corpo centrado, denominada de fase beta $(\beta)$, que permanece até seu ponto de fusão, a $1668^{\circ} \mathrm{C}$. A temperatura de transição $\alpha \rightarrow \beta$ pode ser alterada pela adição de elementos formadores de liga. Comumente, a adição de elementos de liga é feita para melhorar a resistência mecânica ou à corrosão ${ }^{46,47}$. Os elementos denominados $\alpha$ estabilizadores ( $\mathrm{Al}, \mathrm{C}, \mathrm{O}$ e $\mathrm{N}$ ) promovem o aumento da temperatura de transformação de fase $\alpha \rightarrow \beta$, e a adição de metais $\beta$ - estabilizadores (Mo, V, Ta, Nb, Zr, Cr, Mn, Fe, Si, Co, $\mathrm{Ni} \mathrm{e} \mathrm{Cu}$ ) tendem a diminuir a temperatura de transformação ${ }^{48}$. A quantidade e o tipo de elementos $\beta$ - estabilizadores alteram a distribuição e morfologia das fases e, 0 comportamento mecânico da liga e sua resposta a tratamentos térmicos. A presença de $\beta$ - estabilizadores possibilita a liga apresentar uma faixa de temperatura na qual coexistam as duas fases, $\alpha$ e $\beta$. Portanto a classificação das fases microestruturais de ligas de titânio são: Ligas $\alpha$, Ligas $\beta$, Ligas $\alpha+\beta$ e Ligas próximas de $\alpha$ ou $\beta$ (com predominância da referida fase) ${ }^{46,47,48}$.

A liga Ti-6Al-4V e o titânio puro são os materiais mais utilizados para confecção de implantes, e apesar de muito empregados como biomateriais, estudos têm mostrado certa toxicidade neurológica associada ao alumínio (mal de Alzheimer), e problemas respiratórios causados pelo vanádio ${ }^{49,50}$.

Tem sido estudada a substituição, na liga Ti-Al-V, de vanádio por nióbio, resultando na liga Ti-6AI-7Nb, esta liga foi aprovada em 1987 pela FDA (Food and Drugs Admisnistration) para utilização em implantes cirúrgicos, e normatizada pela ASTM em 1992 (ASTM F1295). Outra tendência é o desenvolvimento de ligas sem os elementos citotóxicos, como a liga Ti-13Nb-13Zr, estudada neste trabalho. Além da vantagem de ser completamente biocompatível, a liga Ti-13Nb-13Zr apresenta baixo módulo de elasticidade aliado a elevados valores de resistência mecânica e corrosão ${ }^{49,51,52}$.

O nióbio (Nb) apresenta densidade de $8,57 \mathrm{~g} / \mathrm{cm}^{3}$, ponto de fusão de $2477^{\circ} \mathrm{C}$ e sua ebulição ocorre a $4744^{\circ} \mathrm{C}{ }^{52}$. Apesar de sua excelente característica de resistência à corrosão, o nióbio ainda é pouco explorado como biomaterial. Isto pode estar relacionado à baixa disponibilidade deste metal nos países de liderança tecnológica, diminuindo o interesse pelo desenvolvimento e utilização do nióbio nesta área. O Brasil possui a maior reserva do nióbio no mundo, sendo também o maior produtor deste metal, por isso é importante o desenvolvimento de materiais com nióbio para impulsionar o nível da pesquisa brasileira no cenário mundial. 
O zircônio $(\mathrm{Zr})$ é o outro elemento $\beta$ - estabilizador da liga Ti-13Nb-13Zr, apresenta densidade de $6,52 \mathrm{~g} / \mathrm{cm}^{3}$, ponto de fusão de $1855^{\circ} \mathrm{C}$ e sua ebulição ocorre a $4409^{\circ} \mathrm{C}$. A elevada resistência à corrosão e a não citotoxicidade, propicia a utilização deste metal na área biomédica ${ }^{52}$. O zircônio é encontrado na natureza associado ao háfnio, o seu processo de purificação é bastante caro e específico, zircônio é aplicado principalmente como revestimento em reatores nucleares ${ }^{53}$.

\subsubsection{Metalurgia do pó}

Apesar das excelentes propriedades do titânio e suas ligas, como, baixa densidade, elevadas resistências mecânica e à corrosão, deve-se salientar a dificuldade de usinagem. A alta reatividade química e baixa condutividade térmica geram elevadas temperaturas na zona de corte, ocasionando problemas de desgaste por difusão. Devido aos problemas durante usinagem, conformações mecânicas, complexidade do processo de extração e a dificuldade de fusão, o titânio e suas ligas tornam-se mais caros quando comparados a outros metais. Desta forma, a metalurgia do pó vem sendo introduzida como alternativa mais econômica, produzindo peças próximas ao formato final, "near-netshape" ${ }^{47}$.

O desenvolvimento do titânio com processamento por metalurgia do pó foi impulsionado em função da aplicação na indústria aeroespacial nas últimas décadas, há a necessidade de minimizar os materiais desperdiçados durante a fabricação, diminuindo os custos de produção ${ }^{54}$.

As características dos pós metálicos dependem basicamente das rotas de produção, que podem ser: por métodos mecânicos (atomização de metais fundidos, quebra e moagem), químicos (reações de redução) e eletrolíticos (deposição eletrolítica). O resultado do produto final após o processamento por metalurgia do pó está diretamente relacionado com: formato do particulado, superfície específica, distribuição granulométrica, composição química, escoabilidade, densidade aparente e compressibilidade ou compactabilidade ${ }^{55}$.

A escolha do tipo de material particulado a ser usado para conformação e sinterização depende do fator de forma da partícula e da rugosidade da mesma. Pós que diferem do formato esférico geralmente possuem baixa escoabilidade, e em alguns casos é necessário misturar algum tipo de lubrificante para o preenchimento uniforme da matriz de compactação. Este procedimento, quando aliado à vibração da matriz, otimiza a densificação do pó fazendo com que o compactado apresente maior densidade à verde. 
A granulometria é de fundamental importância; pós mais grosseiros, por exemplo, são mais fáceis de serem compactados, porém aumenta a dificuldade de se obter uniformidade na densificação. Uma larga faixa de distribuição granulométrica beneficia a compactação pela ocupação das partículas mais finas entre os espaços das partículas maiores facilitando o empacotamento ${ }^{55,56}$. Alguns exemplos de morfologia de pó metálico estão dispostos na Figura 1.
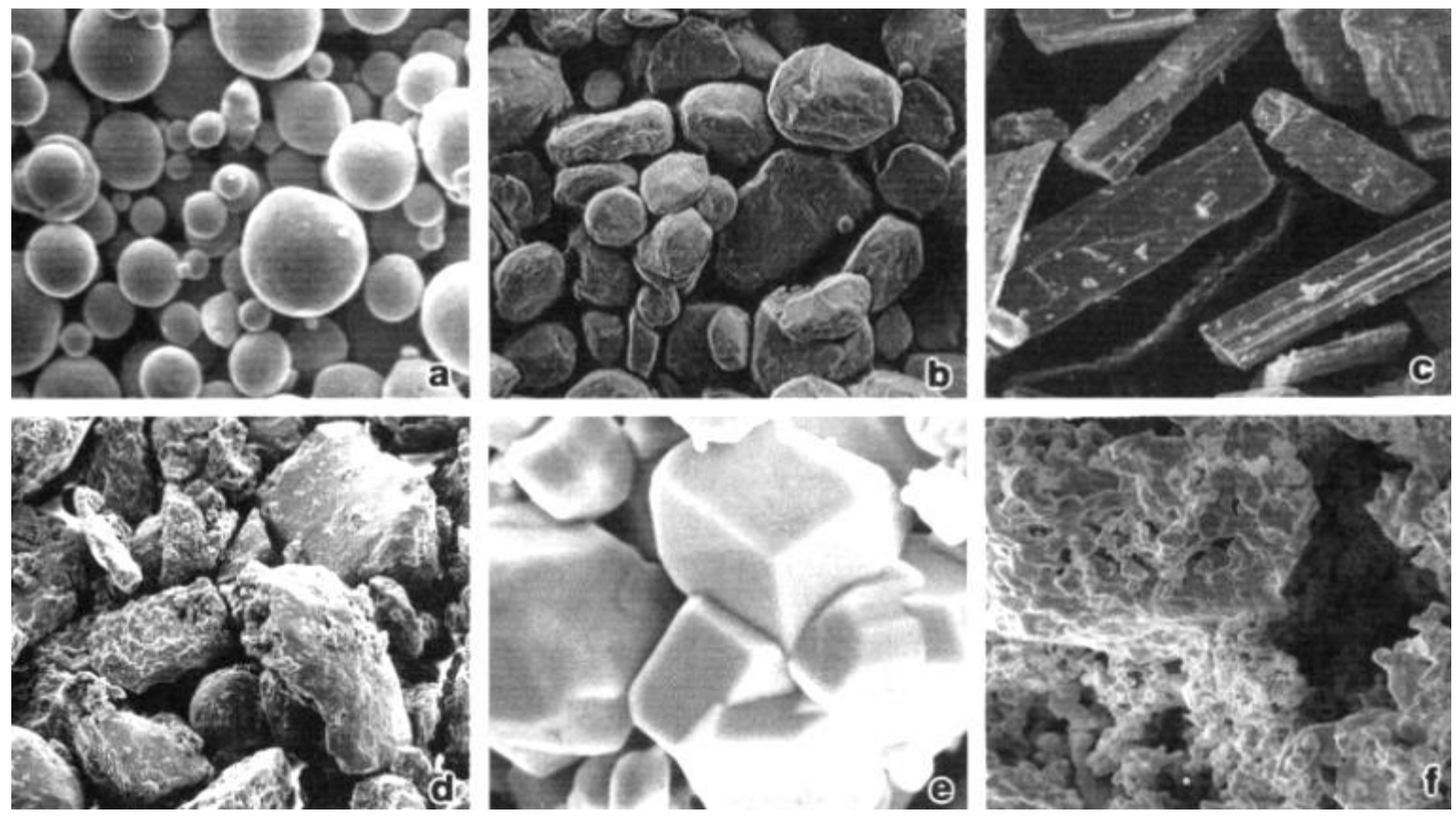

Figura 1. Variadas formas de pós metálicos: A) esférico, B) arredondado, C) angular, D) irregular, E) poligonal, F) esponjoso ${ }^{56}$.

Na metalurgia do pó, a próxima etapa após a compactação é a sinterização, que reduz a energia de superfície livre com a eliminação de contorno de grão, via crescimento de grão. A ativação térmica propicia o transporte de matéria aumentando o contato entre as partículas, reduzindo o volume e alterando a geometria dos poros. Para explicar a sinterização, vários estágios e mecanismos de transporte de matéria no estado sólido têm sido propostos, como: a difusão superficial, difusão volumétrica, difusão por contorno de grão, fluxo viscoso, fluxo plástico e transporte de matéria via fase gasosa ${ }^{54,55}$.

Dependendo do tipo de material e do tamanho das partículas, a temperatura de sinterização necessária para induzir o compactado a iniciar o vínculo entre as partículas e aumentar a densificação, pode variar entre $50 \%$ a $80 \%$ da temperatura de fusão. Alguns parâmetros estão inter-relacionados, como temperatura, tempo de sinterização e tamanho de partícula. Quanto maior a temperatura, menor o tempo de sinterização ou 
ainda, quanto menor for o tamanho das partículas, menor o tempo do processo ${ }^{54}$. Para o modelo de esferas, a sinterização pode ser dividida em três estágios principais (Figura 2).
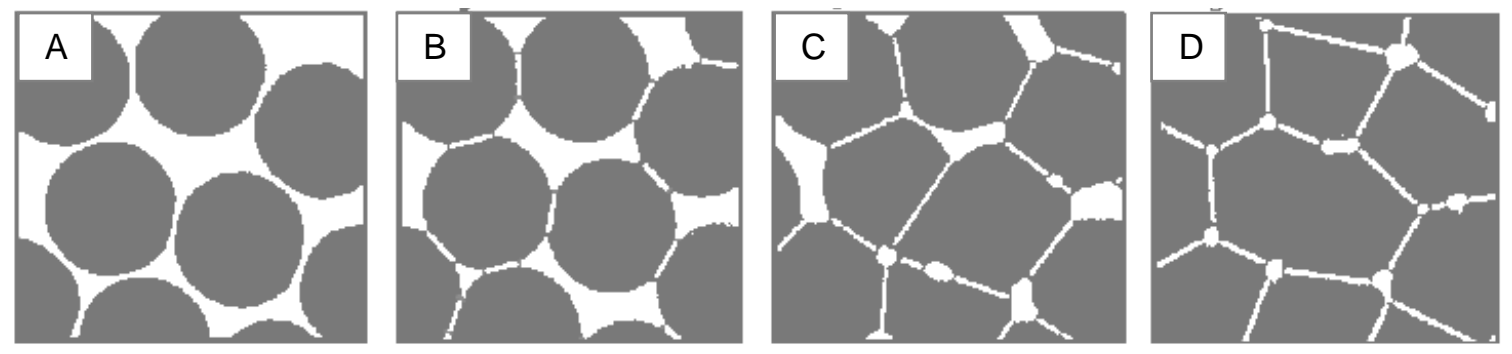

Figura 2. Processo de sinterização, principais estágios: A) pó solto, B) estágio inicial, C) estágio intermediário, D) estágio final ${ }^{54}$.

O primeiro estágio representa a formação de pescoço, mantendo a identidade das partículas, estas entram em contato e com o crescimento dos pescoços ocorre uma aproximação dos centros das partículas caracterizando uma leve retração volumétrica. No estágio intermediário, as partículas perdem gradativamente suas identidades pelo crescimento de grãos do material. Os poros formam uma "rede comunicante" pela gradativa redução nos raios de curvatura. Essas características de aumento na continuidade de matéria e redução no volume de poros, propiciam a retração no volume do sinterizado. No estágio final, o sinterizado pode chegar a ter 90 a $95 \%$ da densidade teórica, decorrente do fechamento, arredondamento e isolamento dos poros. A dificuldade de aumentar a densidade é caracterizada pela insolubilidade dos gazes no sólido, aprisionados no interior dos poros ${ }^{55}$.

\subsection{Biomateriais metálicos porosos}

Titânio e suas ligas são amplamente utilizados como biomateriais, em ortopedia e odontologia, mas ainda existem problemas a serem resolvidos e parâmetros a serem melhorados ${ }^{57}$. A elevada rigidez dos materiais dos implantes quando comparada à do osso circundante, pode originar problemas de tensão e subsequente falha do implante ${ }^{58}$. A diferença de módulo de elasticidade entre o osso (10 - 30 GPa) e os biomateriais metálicos maciços (entre $100 \mathrm{GPa}$, para o Ticp e $230 \mathrm{GPa}$, para as ligas $\mathrm{Co}-\mathrm{Cr}$ ) tem sido identificada como uma das razões de perda de implante ${ }^{4}$.

Para fazer frente a este problema têm-se desenvolvido materiais porosos e osteocondutivos para a regeneração óssea. A vantagem da utilização de materiais com a estrutura porosa é a capacidade de permitir uma ancoragem biológica para os tecidos 
circundantes através do crescimento ósseo no interior dos poros. Além disso, o valor do módulo elástico pode ser ajustado ao do osso trabecular, prevenindo assim a reabsorção óssea na interface do implante ${ }^{58,59}$.

Pesquisas em materiais porosos que permitem o crescimento ósseo tiveram início na década de 1970 envolvendo materiais cerâmicos, poliméricos e metálicos. Embora os materiais cerâmicos possuam excelente resistência à corrosão, as estruturas cerâmicas porosas não podem ser usadas em condições sujeitas a cargas, devido à sua fragilidade intrínseca. Os sistemas poliméricos porosos também enfrentam dificuldades em relação aos esforços mecânicos. Isto levou a pesquisa mais intensa para o processamento de metais, principalmente o titânio ${ }^{58,59,60}$.

A obtenção de metais porosos é investigada desde 1943, quando B. Sosnik ${ }^{4}$ obteve espuma metálica acrescentando mercúrio ao alumínio fundido. Em aplicações biomédicas o conceito do uso de metais porosos foi avaliado mais tarde por Weber e White (1972), mencionando osteointegração ${ }^{4}$. Atualmente existem várias técnicas para a obtenção de materiais metálicos porosos, utilizando processamento por metalurgia do pó (MP). O pó metálico é sinterizado, sendo frequentemente utilizado na forma hidrogenada, diminuindo a formação de óxidos durante o processo.

Uma das técnicas mais simplificada é a produção de poros por "space-holder", que são geralmente compostos orgânicos misturados ao pó metálico, e quando eliminados são mantidas as estruturas anteriormente ocupadas por eles. São exemplos de compostos orgânicos: carbonato de amônio hidrogenado, uréia, gelatina, cloreto de sódio, etc. $\mathrm{O}$ pó de $\mathrm{TiH}_{2}$ misturado com partículas de carbonato de amônio hidrogenado, prensados e sinterizados em forno alto-vácuo $\left(1300^{\circ} \mathrm{C} / 2 \mathrm{~h}\right)$, formam amostras com 44 a $62 \%$ de porosidade (Figura 3) ${ }^{61}$. Enquanto que adição de uréia ao pó de $\mathrm{TiH}_{2}$ proporciona poros estruturais médios de $360 \mu \mathrm{m}$, com porosidade total de $36 \%{ }^{62}$.
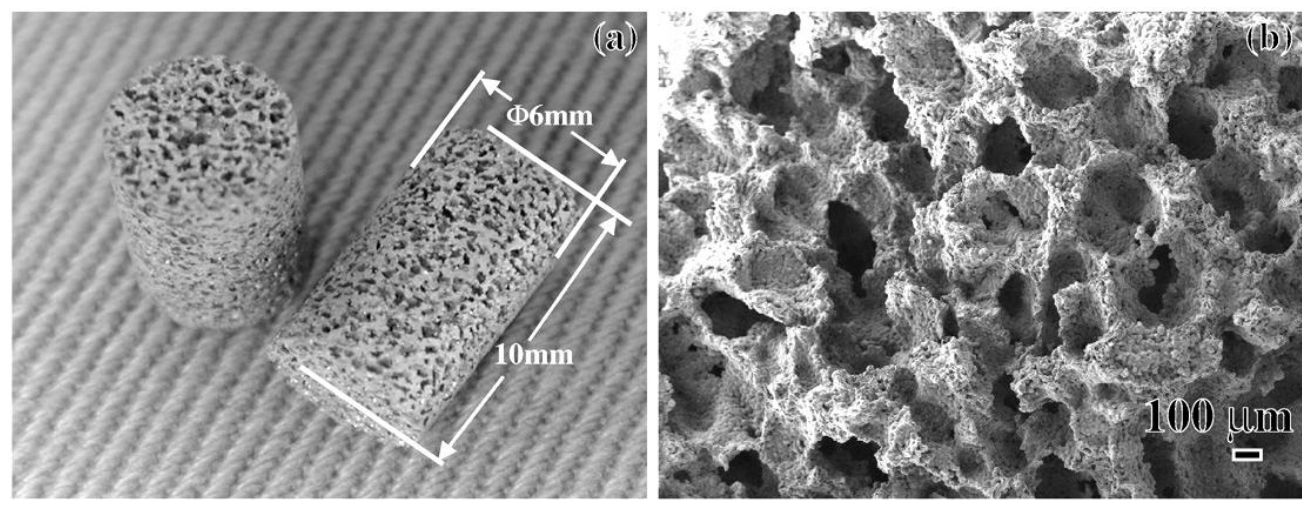

Figura 3. Poros obtidos por "space-holder", MEV da superfície após a sinterização ${ }^{61}$. 
O cloreto de sódio $(\mathrm{NaCl})$ como "space-holder" apresenta características como baixo custo, rápida dissolução em água, baixa impregnação no metal durante a dissolução e baixa toxicidade residual. Os parâmetros envolvidos no processo são pressão de compactação, temperatura e agitação da água e tempo de dissolução do cloreto antes da sinterização ${ }^{63}$.

Por metalurgia do pó é possível obter peças com diferentes densidades em um mesmo corpo de prova. Em uma primeira etapa de prensagem, é formado o núcleo denso da peça pela compactação do pó metálico (Figura 4), na segunda etapa de prensagem, o pó metálico associado à uréia forma uma camada externa porosa ${ }^{62}$. Esta formação complexa também pode ser observada pelo método de sinterização por descarga elétrica, que apesar de formar poros na estrutura, não utiliza nenhum aditivo no processo. Partículas esféricas metálicas são unidas pela formação de pescoços durante a sinterização (Figura 5). Suspensas por vibração, essas partículas se prendem ao corpo denso e são imediatamente sinterizadas por descarga elétrica, resultando em um corpo de prova com diferentes densidades ${ }^{64,65 .}$

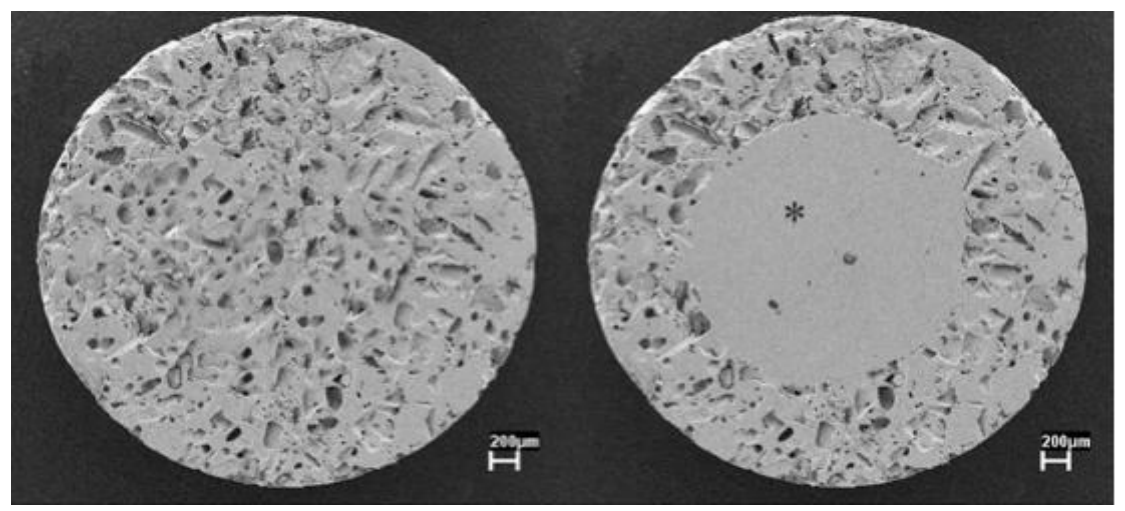

Figura 4. Secção dos "scaffolds" produzidos por metalurgia do pó associado à uréia: à esquerda o titânio totalmente poroso, à direita o núcleo denso com superfície porosa ${ }^{62}$.
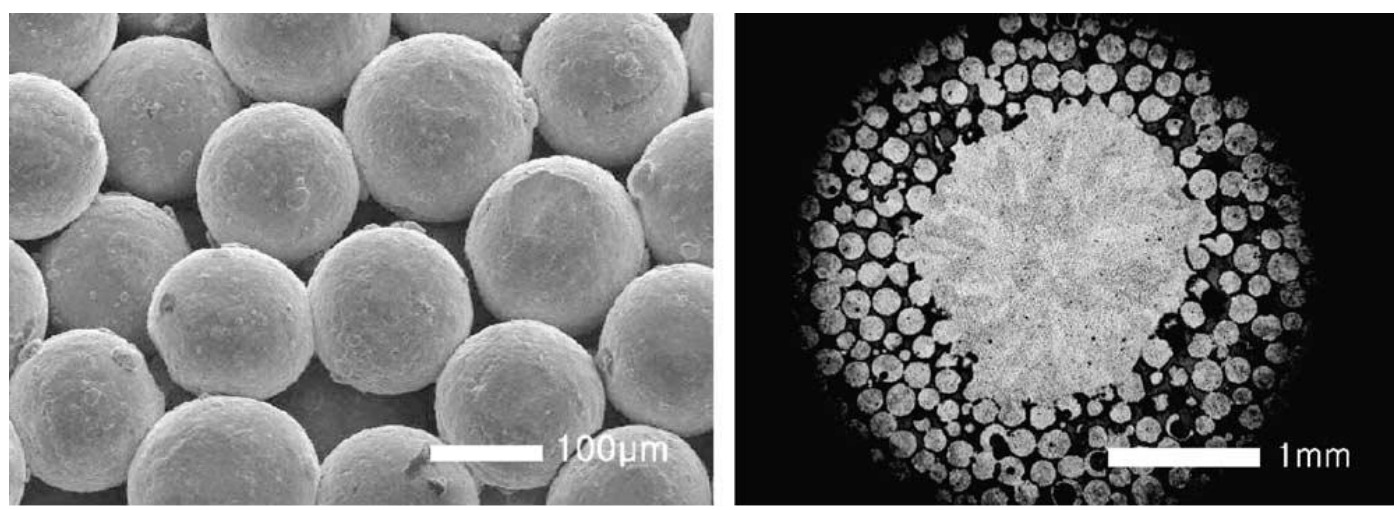

Figura 5. Formação de pescoço entre as partículas esféricas. Secção transversal de implante obtido por sinterização por descarga-elétrica ${ }^{64}$. 
Outros tipos de processamento, por exemplo, moldagem por injeção, necessitam uma preparação mais elaborada do pó para melhorar suas características de escoabilidade de forma a preencher completamente as cavidades do molde. Esta preparação é feita através da mistura com aditivos, que podem ser de diversos tipos, como, ligantes poliméricos sintéticos ou naturais, lubrificantes sintéticos ou minerais, e surfactantes. Cada um desses aditivos desempenha uma função no sistema pó/aditivos minimizando o atrito entre partículas, aumentando a escoabilidade e a plasticidade da massa durante a moldagem ${ }^{54}$.

São característica da metalurgia do pó, a obtenção de peças de formato complexo e dimensões próximas às finais ("near net shape"), evitando, ou minimizando, a etapa de usinagem. A técnica de "metal injection moulding" (MIM) oferece a eficiente combinação da moldagem por injeção plástica e a metalurgia do pó, em produção em massa ${ }^{66}$. A mistura na proporção de $35 \%$ em volume de titânio com um sistema aglutinante $(60 \%$ de parafina, 35\% de polietileno acetato de vinila e 5\% de ácido esteárico, todos em relação ao peso) possibilita obter materiais com até $5,7 \%$ de porosidade e poros variando entre 30 e $90 \mu \mathrm{m}$ (Figura 6) ${ }^{67}$.

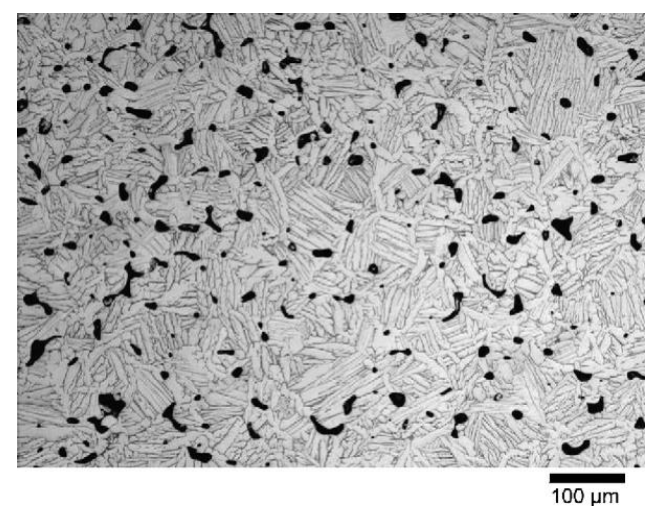

Figura 6. Poros formados pela técnica de $\mathrm{MIM}^{24}$.

Outra técnica de produção de poros e metalurgia do pó envolve o preparo de uma suspensão com o pó metálico. A água presente na suspensão em algumas metodologias é removida por sublimação ("freeze-drying") ou secagem em estufa. A preparação da suspensão contendo água e $10 \%$ em volume de canfeno, forma uma pasta ao adicionar pó de $\mathrm{TiH}_{2}$, que preenchida em moldes endurece à temperatura de $42^{\circ} \mathrm{C}$. O tamanho de poro é diretamente relacionado ao tempo de endurecimento da amostra, quanto mais tempo (7 dias) maiores são os poros $(271 \mu \mathrm{m})$ (Figura 7$)$. Antes do tratamento térmico 
$\left(1300^{\circ} \mathrm{C} / 2 \mathrm{~h}\right)$, as amostras passam pelo processo de "freeze-drying". A porosidade para as amostras obtidas por suspensão e canfeno foi de $64 \%{ }^{68,69}$.
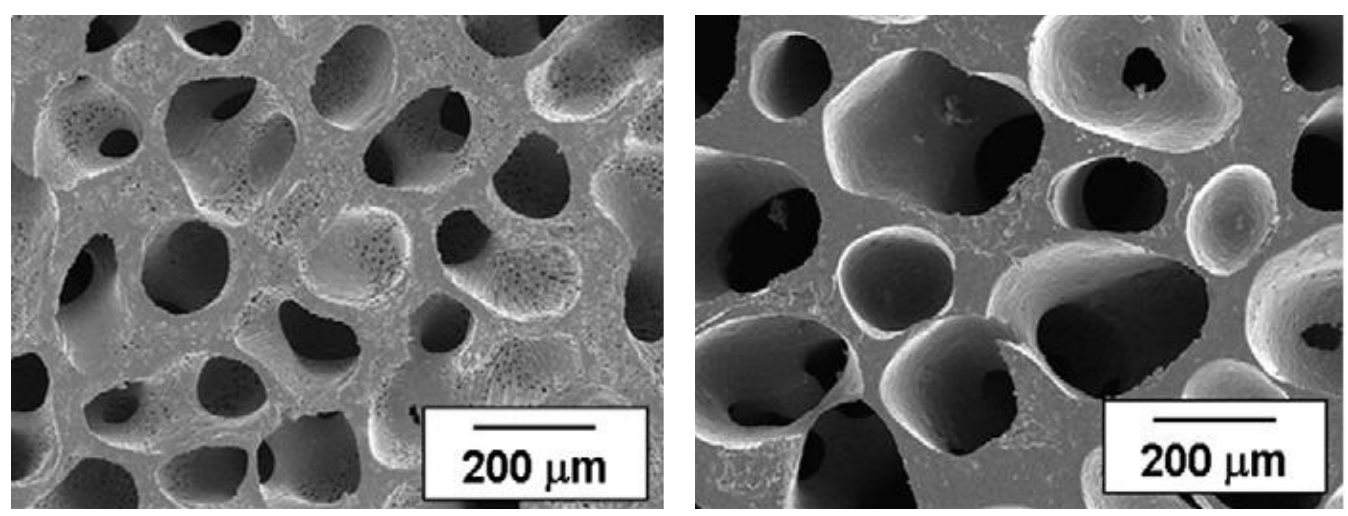

Figura 7. MEV das amostras produzidas por adição de canfeno: à esquerda endurecida por 1 dia, à direita endurecida por 7 dias ${ }^{68}$.

O "freeze-drying" também é utilizado no processamento por "freeze-cast". A orientação da porosidade é um fator que pode ser controlado por este processo, no qual poros são produzidos a partir de suspensões aquosas congeladas de pós metálicos. $\mathrm{Na}$ preparação da suspensão aquosa, faz-se a desgaseificação da água e adiciona-se $0,2 \%$ de ágar. Os $22 \%$ de Ti em volume na suspensão, promovem até $55 \%$ de porosidade. Os poros formados são resultantes dos prolongamentos dendríticos de gelo, que é removido por "freeze-drying" durante 24 horas em vácuo $\left(6 \times 10^{-6}\right.$ torr). A pré-sinterização feita em $1000^{\circ} \mathrm{C} / 2$ horas precede a sinterização $\left(1150^{\circ} \mathrm{C}\right)$, com variação de 8 a 24 horas de patamar (Figura 8) ${ }^{70}$.
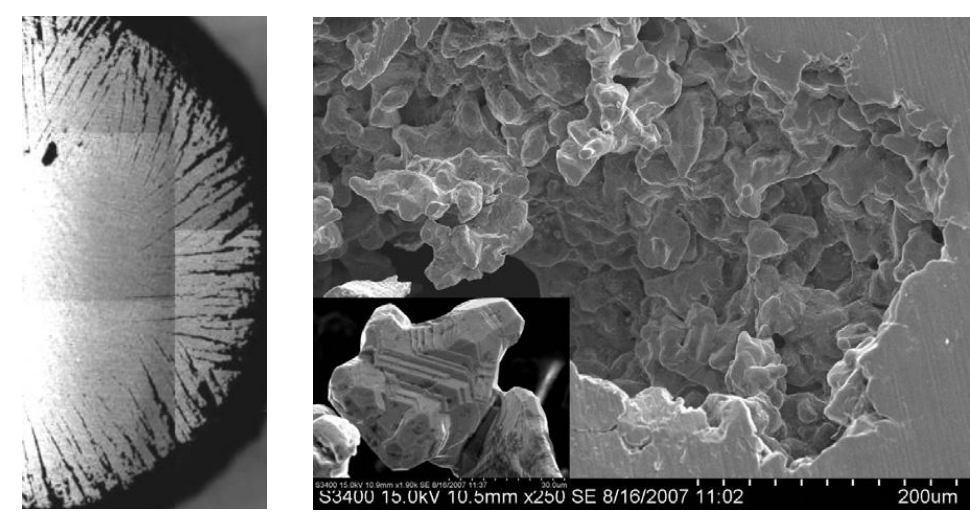

Figura 8. À esquerda, grande poros radialmente orientados observados à olho nu de uma secção da amostra. À direita, MEV de uma amostra seccionada com 44,6\% de porosidade ${ }^{70}$. 
Suspensões aquosas que tem a eliminação da água por calor necessitam de ligantes para promover a união entre as partículas de sólidos, conferindo resistência ao material à verde. Da mesma forma, a utilização de dispersantes (ou defloculantes) é necessária para aumentar a fluidez das suspensões pelo desenvolvimento de forças repulsivas entre as partículas, estabilizando-as, evitando a aglomeração. Outro exemplo de preparo de suspensão aquosa é a utilização de carboximetil celulose de sódio (CMC), hexametafosfato de sódio (SHMP) e $\mathrm{H}_{2} \mathrm{O}_{2}$; como ligante, dispersante e agente espumante, respectivamente. O agente espumante é responsável pela formação de bolhas que resultam na estrutura porosa. O pó de Ti misturado à suspensão é preenchido em moldes, e seco durante 3 horas sob $40-60^{\circ} \mathrm{C}$. As amostras são sinterizadas a $1300^{\circ} \mathrm{C}$, em vácuo. A porosidade final foi de 76\%, com macroporos na faixa de 100-400 $\mu \mathrm{m}$ e microporos de $\sim 10 \mu \mathrm{m}$, encontrados não apenas na superfície mas também nas paredes dos macroporos (Figura 9) ${ }^{71}$.

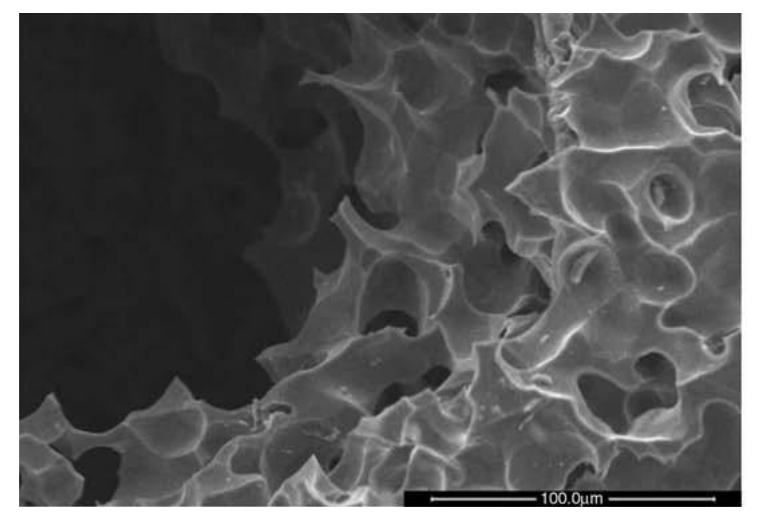

Figura 9. Presença de microporos nas paredes dos macroporos ${ }^{71}$.

O método da replicação de esponja por infiltração envolve blocos poliméricos de morfologia determinada, mergulhados em suspensão contendo pó metálico. Após a impregnação, a secagem é feita em temperatura ambiente $\left(24^{\circ} \mathrm{C}\right)$ e o bloco polimérico é removido por tratamento térmico, restando apenas a cópia da estrutura em titânio, que é então sinterizado. Utilizando este método e suspensão de água, $45 \%$ de $\mathrm{TiH}_{2}, 0,3 \%$ de dispersante e $0,07 \%$ de k-carragenano; há a formação de uma estrutura com $75 \%$ de porosidade, e macroporos entre 100-600 $\mu \mathrm{m}$ de dimensão, comparável com a porosidade do osso trabecular (Figura 10) ${ }^{18}$. 


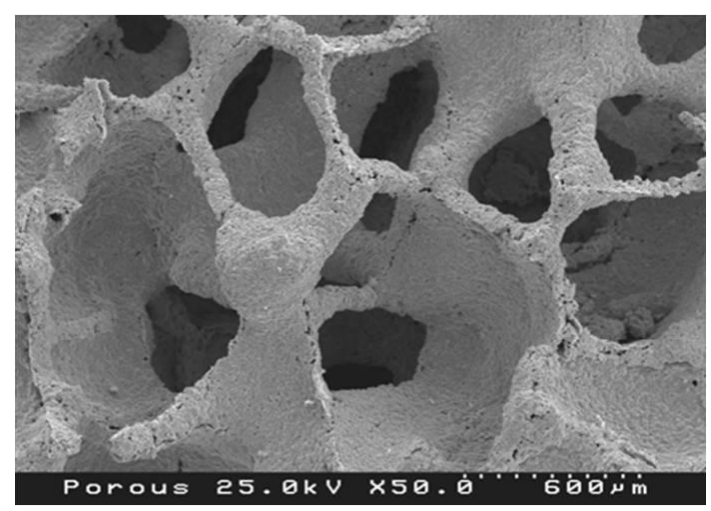

Figura 10. Micrografia de MEV mostrando a arquitetura de estrutura porosa obtida de replicação de esponja polimérica, após sinterização ${ }^{18}$.

A prototipagem é um método que também utiliza um modelo pré-estabelecido, reproduzindo fielmente a estrutura porosa pela deposição da suspensão metálica em camadas. A suspensão pode ser formada por partículas de Ticp e álcool polivinílico, este é removido por tratamento térmico previamente à sinterização ${ }^{72}$.

A fusão por feixe de elétrons (FFE) é uma técnica em que se utiliza um modelo base de estrutura pré-formada. Um modelo 3D assistido por computador é avaliado por camadas de espessura constante para fornecer informações precisas. O processo começa com a aplicação uniforme de uma camada de pó metálico sobre uma plataforma. Após uma etapa de pré-aquecimento, um feixe de elétrons varre a camada de pó e cria uma seção transversal da parte pela fundição das partículas de pó depositado. Posteriormente, outra camada de pó é aplicada e o processo é repetido até que toda a peça seja construída (Figura 11). O processo é realizado sob vácuo $\left(10^{-4} \text { a } 10^{-5} \mathrm{mBar}\right)^{73}$. Diferente das demais técnicas utilizando a MP, esta em especial não sinteriza o pó metálico, mas funde as partículas pela elevada energia empregada no processo.

Estas metodologias que utilizam um modelo 3D permitem a obtenção de implantes metálicos personalizados usando o método forma livre de fabricação (FFF). Com o auxílio de tomografia computadorizada de um paciente é possível criar uma peça individualizada que tenha perfeito ajuste, em caso de substituição de tecido ósseo ou preenchimento de defeito. A complexa estrutura do osso medular, com $50-70 \%$ de porosidade interconectada, pode ser reproduzida por esta técnica que favorece tanto a parte mecânica, como a osteointegração. Implantes porosos com finalidade ortopédica são obtidos apresentando uma estrutura de malha aberta com células unitárias hexagonais com 1,4 mm de diâmetro. A técnica FFE proporciona a formação de poros com aproximadamente $650 \mu \mathrm{m}$ e porosidade de $76 \%{ }^{74}$. 

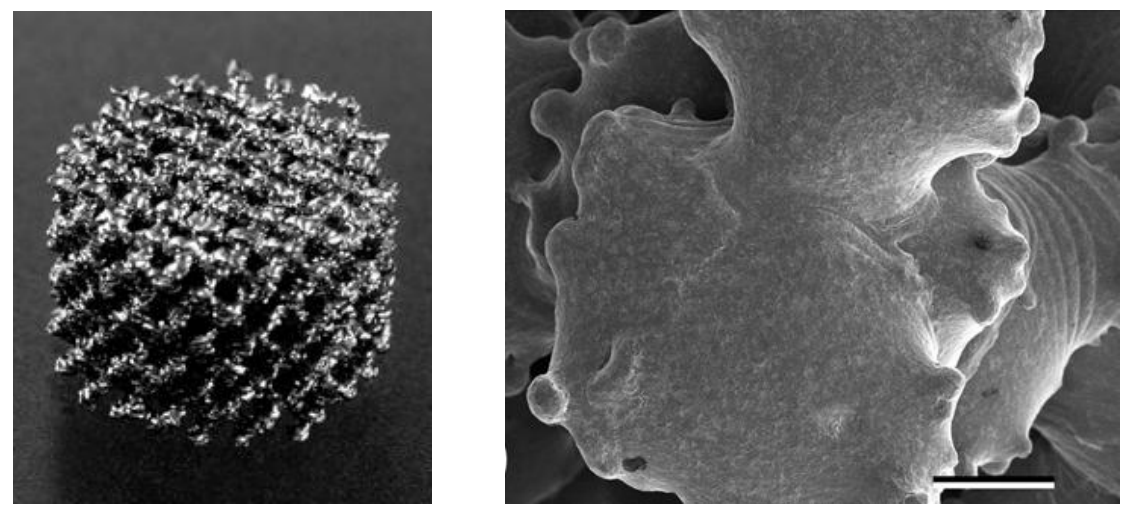

Figura 11. Disco poroso produzido por FFE com $76 \%$ de porosidade, e MEV da superfície 26 .

Outras possibilidades de produção de materiais porosos são relatadas na literatura. Para a confecção de corpos cerâmicos porosos, polímeros naturais são utilizados na técnica sacrificial, ou como geleificante no processo gelcasting ${ }^{29,75}$.

Os amidos extraídos de diferentes vegetais, como, de milho, de mandioca, de arroz e de batata; são polímeros naturais que podem ser utilizados na obtenção de materiais cerâmicos porosos. O formato arredondado das partículas dos amidos e o tamanho, que pode variar entre 2 e $170 \mu \mathrm{m}$, propiciam a produção de materiais porosos pela técnica sacrificial, semelhante ao "space-holder". Em suspensão, ou por mistura sólida, o amido adicionado à cerâmica é removido por tratamento térmico, assim poros se formam nas posições anteriormente ocupados pelos amidos ${ }^{28}$.

No processo "gelcasting", a suspensão cerâmica contendo amido é vertida em molde e aquecida para enrijecimento da suspensão, seguindo os passos de desmoldagem, secagem, eliminação do orgânico e sinterização. Em contato com a água e aquecido, o amido apresenta um enfraquecimento das suas ligações intermoleculares, proporcionando a absorção de água de uma maneira irreversível pelas partículas. A expansão volumétrica pode atingir até $20 \%$, sendo bastante favorável para a técnica em questão ${ }^{29}$.

A alta capacidade hidrofílica das partículas de amido advém das unidades de glicose expostas que contém uma grande quantidade de grupo hidroxila que possuem afinidade com a água. Dois tipos de polissacarídeos compõem o amido, um linear (amilose) e outro ramificado (amilopectina), sendo que a amilose é responsável pela geleificação em suspensões aquosas ${ }^{29}$. Os hidrogéis de alginato são polímeros naturais que possuem também a característica de hidrofilicidade. Encontrado nas células de algas marrons, o ácido algínico é um polímero linear de alta massa molar, com grande 
afinidade a cátions metálicos como o $\mathrm{Na}^{+}$, gerando o composto alginato de sódio. Esse composto apresenta grande solubilidade em soluções aquosas, despertando o interesse da área biomédica em diversos aspectos. A biocompatibilidade é um fator favorável associado à produção de biomateriais ${ }^{76}$.

\subsection{Interação entre metal e tecido ósseo}

A resposta inflamatória frente a um biomaterial é o primeiro passo para o sucesso da integração do biomaterial com o organismo. A inflamação é um conjunto complexo de fenômenos celulares e vasculares específicos a qualquer estímulo, com objetivo de recuperar a homeostase do organismo como um todo ${ }^{77}$. Tudo que possa agredir o organismo pode ser considerado como eventual agente etiológico da inflamação. Dentre as causas endógenas são citadas as reações derivadas de degenerações ou necroses teciduais, e as derivadas de alterações na resposta imunológica. As causas exógenas incluem desde a ação lesiva de alguns agentes físicos, de agentes químicos inorgânicos e orgânicos, assim como de agentes biológicos infecciosos ${ }^{1}$.

A cirurgia representa um estímulo traumático, induzindo uma resposta inflamatória. Dependendo da natureza e características dos biomateriais que compõe as próteses, assim como a topografia e forma, são observadas diferentes intensidades e duração da resposta inflamatória ${ }^{1}$. O tecido de granulação e células gigantes do tipo "corpo estranho" podem compor a reação quando o organismo reconhece o implante como um corpo estranho. Por outro lado, se o implante for de material mais inerte e interagir adequadamente com os tecidos conjuntivos de sustentação da interface, a resposta inflamatória pode ser mínima, com rápida reabsorção por apoptose das células inflamatórias ${ }^{1}$.

Os biomateriais induzem reações biológicas variadas e complexas com o hospedeiro, respostas que podem formar uma interface com vários tipos de tecidos e células. Pode proporcionar a ocorrência de uma sequência de eventos que envolvem adesão, migração e diferenciação celular; desencadeando fenômenos físico-químicos na superfície ao redor do implante ${ }^{1}$.

Essa interação promove uma série de eventos caracterizando várias etapas como: adsorção de proteínas na superfície do biomaterial, troca de íons e rearranjo estrutural do biomaterial e interface do tecido, interdifusão da camada formada na superfície do biomaterial, efeitos mediados pela solução sobre a atividade das células adjacentes ao implante, deposição das fases mineral ou orgânica sem interação com a superfície do 
biomaterial, deposição e interação com o biomaterial, quimiotaxia para superfície do biomaterial, adesão e proliferação celular, diferenciação celular, formação de matriz extracelular ${ }^{1,8}$.

\subsection{Características dos poros na osteointegração}

As características dos poros podem determinar vários fatores na interação osso/implante, entre esses fatores estão a capacidade de migração celular progenitora, ancoramento, nutrição por meio de vasos sanguíneos, módulo elástico do material resultante e mineralização.

Em comparação a implantes usinados densos, os implantes porosos apresentam melhores resultados mecânicos em ensaios de cisalhamento, no qual se avalia a resistência da união interfacial entre osso e implante ${ }^{16}$. A resistência da interface está relacionada ao tamanho de poro, força de união e o tempo do reparo tecidual ${ }^{78}$. O tamanho do poro é uma questão abordada por muitos autores podendo direcionar a migração e maturação de células osteoprogenitoras. Alguns autores ainda determinam que a vascularização não ocorre em poros de diâmetro inferior a $100 \mu \mathrm{m}$, sendo o tamanho de poro adequado à reorganização óssea e vascularização reportado como ótimo no intervalo de $100-500 \mu \mathrm{m}^{13,18}$, para materiais metálicos como mostra a Tabela 1:

Tabela 1. Tamanho de poro ideal relatado por cada autor.

\begin{tabular}{|c|c|c|c|c|c|}
\hline Autor & $\begin{array}{c}\text { tamanho } \\
\text { de poro } \\
\text { ideal } \\
\end{array}$ & Metal & $\begin{array}{c}\text { Tempo de } \\
\text { reparo }\end{array}$ & $\begin{array}{c}\text { Modelo } \\
\text { animal }\end{array}$ & Observação \\
\hline$\underset{15}{\mathbf{L i} \text { et }}$ al & $>140 \mu \mathrm{m}$ & Ticp & $\begin{array}{l}6,12 \text { e } 52 \\
\text { semanas }\end{array}$ & $\begin{array}{l}\text { Fêmur de } \\
\text { coelhos, } \\
\text { machos }\end{array}$ & Implante cilíndrico \\
\hline $\begin{array}{l}\text { Itäla et } \\
\text { al }^{12}\end{array}$ & $>100 \mu \mathrm{m}$ & Ticp & $\begin{array}{l}12 \\
\text { semanas }\end{array}$ & $\begin{array}{l}\text { Fêmur de } \\
\text { coelhos, } \\
\text { fêmeas }\end{array}$ & Implante triangular \\
\hline $\begin{array}{l}\text { Kujala } \\
\text { et } a^{13}\end{array}$ & $\begin{array}{c}260 \sim 500 \\
\mu \mathrm{m}\end{array}$ & $\mathrm{NiTi}$ & $\begin{array}{l}30 \\
\text { semanas }\end{array}$ & $\begin{array}{l}\text { Fêmur de } \\
\text { ratos, } \\
\text { machos }\end{array}$ & Implante cilíndrico \\
\hline $\begin{array}{l}\text { Frosch } \\
\text { et al } 79\end{array}$ & $600 \mu \mathrm{m}$ & Тіср & $\begin{array}{l}5,11 \text { e } 42 \\
\text { dias }\end{array}$ & $\begin{array}{l}\text { Fêmur de } \\
\text { coelhos }\end{array}$ & $\begin{array}{l}\text { Implante cilíndrico } \\
\text { com recobrimento } \\
\text { de células } \\
\text { osteoblásticas }\end{array}$ \\
\hline $\begin{array}{l}\text { Götz et } \\
\text { al }^{17}\end{array}$ & $200 \mu \mathrm{m}$ & Ti6Al4V & $\begin{array}{l}3,6 \text { e } 12 \\
\text { semanas }\end{array}$ & $\begin{array}{l}\text { Fêmur de } \\
\text { coelhos, } \\
\text { fêmeas }\end{array}$ & Implante cilíndrico \\
\hline
\end{tabular}


A estrutura porosa deve mimetizar a arquitetura do osso natural, possuindo porosidade interligada, com espaço suficiente para a migração celular, ancoragem e proliferação de tecido ósseo novo, vascularização e transporte dos fluidos corporais ${ }^{57}$. 
Objetivos

Os objetivos compreendem as metas propostas para este trabalho e são descritos a seguir. 


\section{OBJETIVOS}

Este estudo tem como objetivos:

- aprimorar metodologia de obtenção de materiais metálicos porosos, por metalurgia do pó e utilização de polímeros naturais;

- obter materiais porosos por duas técnicas: "space-holder" e suspensão; e realizar caracterização física, avaliando as propriedades importantes, como, homogeneidade estrutural, grau de porosidade, distribuição e tamanho de poros;

- escolher materiais hábeis quanto a compatibilidade com o organismo, por ensaios in vitro de citotoxicidade;

- avaliar capacidade de osteointegração dos implantes porosos, por ensaios in vivo em modelo animal;

- determinar os melhores materiais obtidos para uso como implantes. 
Materiais e Métodos

A metodologia utilizada neste estudo inclui as técnicas para obtenção de materiais metálicos à base de titânio (Ticp e liga Ti-13Nb-13Zr) com variações de porosidade. Os métodos de caracterização física e biológica (ensaios in vitro e in vivo) dos materiais estudados são descritos detalhadamente. 


\section{MATERIAIS E MÉTODOS}

O desenvolvimento de materiais porosos que pudessem ser utilizados como implantes envolveu etapas como: desenvolvimento do processamento para a obtenção das amostras porosas, caracterização física dos materiais porosos obtidos, e caracterização biológica por meio de testes in vitro e in vivo dos implantes.

Para o desenvolvimento do processamento das amostras porosas foram utilizados titânio hidretado $\left(\mathrm{TiH}_{2}\right)$ com adição de polímeros naturais em pó, pelas técnicas de "space-holder" e suspensão. Foi realizado estudo com diferentes tipos e quantidades de polímeros naturais para obter variadas características quanto a distribuição de tamanho de poros.

Selecionadas as amostras porosas com $\mathrm{TiH}_{2}$, as mesmas técnicas foram aplicadas utilizando como metal base o titânio, o nióbio e o zircônio, nas proporções estequiométricas da liga Ti-13Nb-13Zr. A caracterização física permitiu selecionar os materiais pelas melhores propriedades como: homogeneidade estrutural, distribuição do tamanho de poros, entre outros. Visando o objetivo da utilização do implante metálicos poroso em tecido ósseo, primeiramente foi necessária a análise da toxicidade do material por teste de citotoxicidade em cultura celular. Aos implantes que não apresentaram potencial tóxico, foi avaliado o comportamento in vivo pela interação do material com o tecido ósseo. Por meio de análise histológica foi possível fazer uma análise qualitativa e quantificar o crescimento do osso no interior dos poros dos implantes, em íntimo contato com o mesmo, caracterizando a osteointegração.

\subsection{Caracterização do material particulado}

No desenvolvimento dos materiais porosos foi utilizado titânio hidretado $\left(\mathrm{TiH}_{2}\right.$, Brats). Apresentado na forma particulada, a caracterização do pó foi realizada por: espectrometria de fluorescência de Raios-X (EDXRF); difração de Raios-X (DRX) (DMAX 2000, Rigaku) com radiação Cu-Ka; microscopia eletrônica de varredura (MEV) (Philips XL 30) e distribuição granulométrica (CILAS granulometer - modelo 1064).

A liga Ti-13Nb-Zr foi obtida pela mistura dos pós metálicos de Ti (268496, Sigma-Aldrich), Nb (262722, Sigma-Aldrich) e Zr (403296, Sigma-Aldrich). Por se tratar de pós comerciais, foram feitas as caracterizações quanto à morfologia (MEV), distribuição granulométrica (CILAS) e DRX. 
Os polímeros naturais: amido de arroz (Creme de Arroz, YOKI), amido de batata (Fécula de Batata, YOKI), amido de milho (MAIZENA®, Unilever), gelatina (CAAR), albumina (Ovalbumina, Sigma-Aldrich); foram caracterizados por análise termogravimétrica, para avaliar a perda de massa em função da temperatura, e por distribuição granulométrica (CILAS). Os pós metálicos e o hidreto também foram analisados por termogravimetria com a finalidade de determinar o ganho de massa pela formação de óxido em atmosfera oxidante.

\subsection{Processamento de porosos}

No desenvolvimento de materiais porosos foram utilizados polímeros naturais como o amido de milho, amido de batata, amido de arroz, albumina, alginato e gelatina; em duas técnicas de processamento, por suspensão e "space-holder". A primeira técnica consiste na formação de porosidade causada pela expansão volumétrica dos polímeros naturais quando em suspensão. Na técnica do "space-holder", compostos orgânicos são misturados ao pó metálico, e quando eliminados são mantidas as estruturas anteriormente ocupadas por eles.

Uma das técnicas utilizada para obtenção de porosidade envolveu a formação de poros por suspensão com adição de metal, utilizando pó metálico misturado à suspensão constituída de água e os polímeros naturais. A proporção utilizada foi de 8 a 16\% em peso de polímero em relação ao total de sólidos, em $1 \mathrm{~mL} / \mathrm{g}$ de água aquecida. Moldes cilíndricos foram preenchidos com a pasta formada com o auxílio de uma seringa para remoção de bolhas. Imediatamente ao preenchimento, o molde foi congelado em nitrogênio líquido e a amostra removida, foi colocada em freezer $\left(-10^{\circ} \mathrm{C}\right)$. Após $12 \mathrm{~h}$, as amostras foram colocadas em estufa $\left(38^{\circ} \mathrm{C}\right)$ previamente ao tratamento térmico e sinterização.

Para a obtenção de amostras porosas pela técnica do "space-holder", foram misturados o pó metálico ao pó do polímero, na proporção de 10 a 30\% em relação ao peso. A homogeneização e desaglomeração realizada em almofariz de alumina precederam as etapas de prensagem, tratamento térmico e sinterização. As amostras foram prensadas isostaticamente em $148 \mathrm{MPa}$.

Todas as amostras foram tratadas termicamente em atmosfera oxidante à $350^{\circ} \mathrm{C}$, por 1 hora e taxa de aquecimento de $1^{\circ} \mathrm{C} / \mathrm{min}$. Este tratamento térmico foi preconizado para a decomposição do material orgânico e remoção do carbono proveniente do mesmo. As amostras, em cadinho de alumina $\left(\mathrm{Al}_{2} \mathrm{O}_{3}\right)$, foram sinterizadas em forno de alto-vácuo 
$\left(10^{-5} \mathrm{mBar}\right)$ com resistência de tungstênio, à $1300^{\circ} \mathrm{C}$, por 1 hora para amostras de Ticp, e 3 horas para amostras da liga.

Por estas duas técnicas foram obtidas amostras de Ticp e da Liga Ti-13Nb-13Zr (Figura 12).

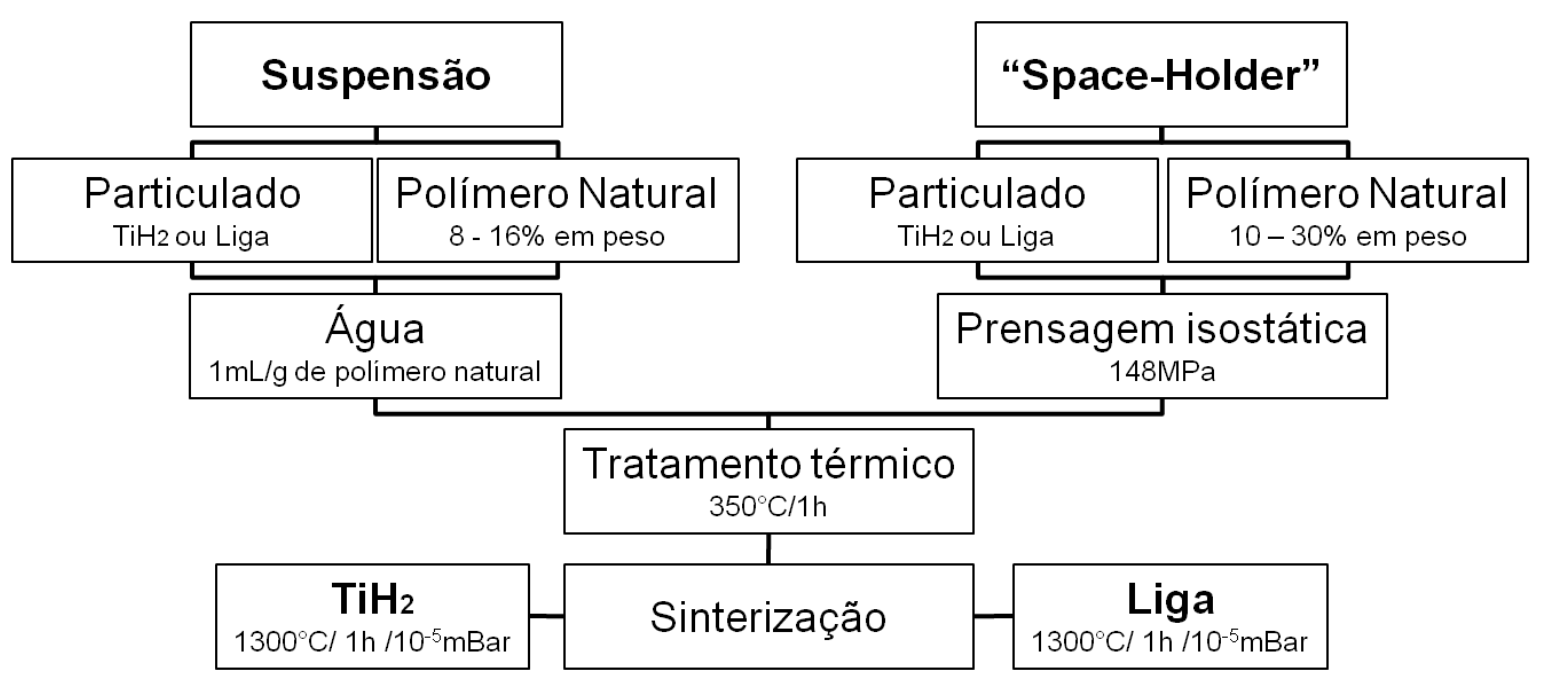

Figura 12. Fluxograma do processamento de porosos.

\subsection{Caracterização física das amostras sinterizadas}

As amostras sinterizadas foram caracterizadas quanto a morfologia da superfície e microestrutura, por microscopia eletrônica de varredura (Philips XL 30); fases cristalinas, por difração de raios X (DMAX 2000, Rigaku); rugosidade, por rugosímetro (SJ-201, Mitutoyo); e porosidade, por densidade hidrostática $(\rho)$, porosidade aparente, picnometria de hélio (Micromeritics Accu Pyc 1330) e análise de imagem (ImagePro Plus 6.1).

- Microscopia Eletrônica de Varredura (MEV)

$\mathrm{Na}$ análise do material realizada em MEV, são obtidas micrografias utilizando elétrons secundários para análise morfológica da superfície e retroespalhados para análise da microestrutura. A análise do interior das amostras teve por objetivo avaliar a homogeneidade microestrutural, a formação das fases $\alpha$ e $\beta$ da liga Ti-13Nb-13Zr e a porosidade.

Para a análise da microestrutura, as amostras foram seccionadas transversalmente em máquina de corte de precisão (Isomet). A preparação das amostras 
seguiu o procedimento padrão utilizada em metalografia, que consiste em: embutimento, lixamento e polimento das amostras. As amostras foram embutidas em resina por impregnação à vácuo, e após a remoção dos excessos de resina das peças com lixas d'água $(600,1000,1200)$, seguiu a fase de polimento com pasta diamantada (6, 3 e 1 $\mu \mathrm{m})$.

- Difração de Raios-X (DRX)

Complementando a identificação das fases $\alpha$ e $\beta$ da liga Ti-13Nb-13Zr, foram feitas análises de DRX com radiação Cuk $\alpha(\lambda=0,1542 \mathrm{~nm})$. Como a liga não apresenta registros na ficha JCPDS, foram comparadas as fases $\alpha$ e $\beta$ do titânio comercialmente puro (Ticp).

- Rugosidade

A rugosidade superficial foi mensurada em rugosímetro de contato (Mitutoyo SJ 201P), sendo realizadas cinco mensurações por amostra.

- Determinação da densidade e porosidade

A porosidade relativa das amostras, foi calculada pela diferença entre a densidade teórica do Ticp $\left(4,51 \mathrm{~g} / \mathrm{cm}^{3}\right)$, ou da liga Ti-13Nb-13Zr $\left(5,01 \mathrm{~g} / \mathrm{cm}^{3}\right)^{52,80}$, e a densidade hidrostática $(\rho)$ medida da amostra (equação I). O meio líquido utilizado para o cálculo de densidade hidrostática foi o querosene, que na temperatura de $25^{\circ} \mathrm{C}$ possui uma densidade de $0,76 \mathrm{~g} / \mathrm{cm}^{3}$.

A porosidade aparente (PA) é calculada seguindo as normas de ASTM C20-00, pela equação (II) ${ }^{81}$ :

$$
\begin{aligned}
& \text { (I) } \rho_{(g / \mathrm{cm} 3)}=\frac{\mathrm{ms}}{\mathrm{mu}-\mathrm{mi}} \times 0,76 \\
& \text { (II) } \quad \mathrm{PA}_{(\%)}=\frac{\mathrm{mu}-\mathrm{ms}}{\mathrm{mu}-\mathrm{mi}} \times 100
\end{aligned}
$$

Onde: $\mathrm{mu}=$ massa úmida, $\mathrm{ms}=$ massa seca, $\mathrm{mi}=$ massa imersa .

A mensuração da área dos poros foi realizada pelo programa ImagePro Plus 6.1, baseada nas micrografias obtidas por elétrons retroespalhados, e foi calculada em relação à área observada, em porcentagem. Foram selecionadas imagens de uma

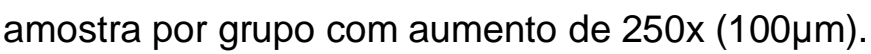


Primeiramente foi selecionada a imagem e os poros foram demarcados individualmente. O programa fornece o valor das áreas demarcadas; pela razão do valor das áreas demarcadas em relação à área total da imagem, obtem-se a porcentagem de porosidade na estrutura (Figura 13).
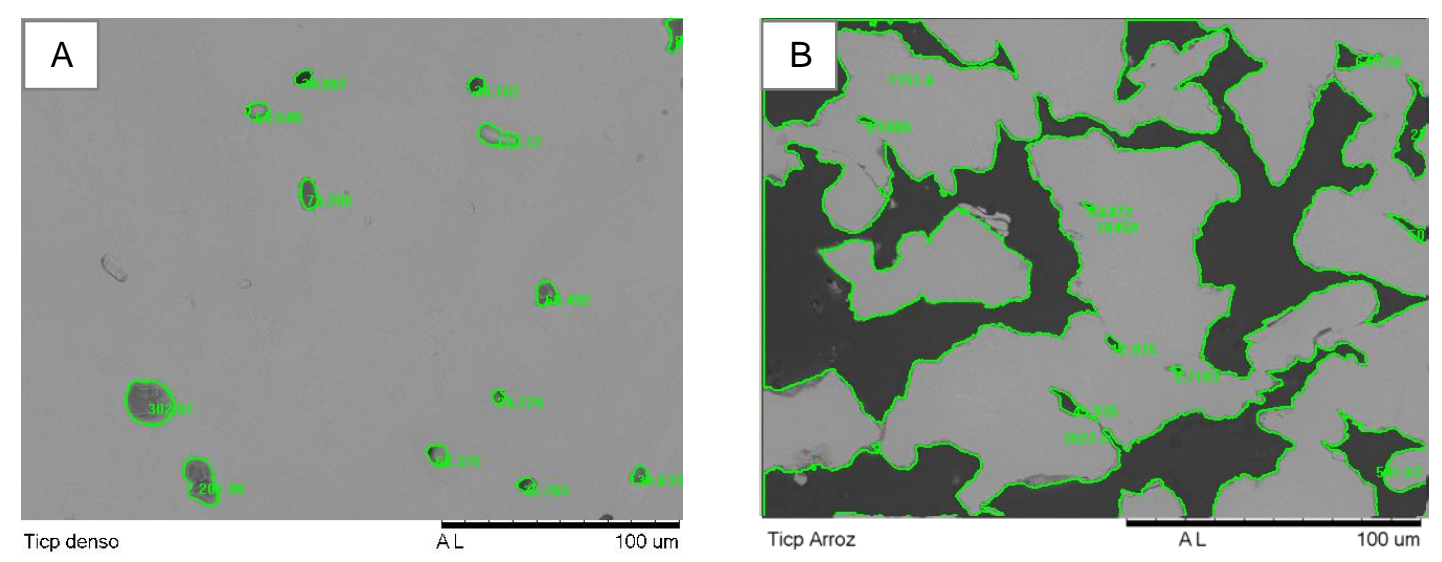

Figura 13. Mensuração da área porosa pela utilização do programa ImagePro Plus: A) exemplificação da mensuração de uma amostra densa de Ticp com $5 \%$ de porosidade, B) exemplificação da mensuração de uma amostra porosa de Ticp com adição de amido de arroz, com $47 \%$ de porosidade.

Por picnometria de hélio foram medidas as densidades $\left(\mathrm{g} / \mathrm{cm}^{3}\right)$ das amostras e relacionando-as aos valores de densidade teórica, foram calculados a quantidade porcentual de poros fechados na estrutura.

\subsection{Grupo controle - denso}

Para a experimentação in vitro e in vivo foram preparadas amostras densas por possuírem respostas biológicas previamente conhecidas, em comparação aos materiais porosos obtidos.

As amostras dos grupos controle, materiais densos de Ticp e Liga Ti-13Nb-13Zr, foram caracterizados quanto à morfologia e microestrutura, por MEV; e estrutura cristalina por DRX. O processamento por metalurgia do pó consistiu na compactação isostática do pó (148 MPa) e sinterização $\left(1300^{\circ} \mathrm{C}\right)^{20}$. O tempo de patamar variou entre as amostras estudadas, para as amostras de Ticp, 1 hora de patamar foi suficiente para uma boa densificação, para a Liga Ti-13Nb-13Zr foram necessárias 3 horas de patamar para a homogeneização de todos os elementos da liga. As amostras foram usinadas no 
formato cilíndrico, próximas às dimensões de $2 \mathrm{~mm}$ de diâmetro por $5 \mathrm{~mm}$ de comprimento.

\subsection{Caracterização biológica das amostras sinterizadas}

Anteriormente aos ensaios in vitro e in vivo, todos os implantes foram esterilizados com uma dose de 25kGy de radiação gama (Co60, Gammacell modelo 220 do Instituto de Pesquisa Energéticas e Nucleares).

\subsubsection{Ensaio in vitro - teste de citotoxicidade}

Todos os implantes porosos metálicos selecionados, tanto constituídos de Ticp como da liga $\mathrm{Ti}-13 \mathrm{Nb}-13 \mathrm{Zr}$, foram avaliados a citotoxicidade seguindo as normas da ISO10993-5 (2009) ${ }^{82}$.

- Preparação celular

Para o processo de preparação celular, as células CHO-k1 (linhagem de células de ovário de hamster chinês) foram mantidas em cultura com meio RPMI 1640 suplementado com antibiótico e antimicótico (penicilina100 unidades $/ \mathrm{mL}$, estreptomicina100 $\mu \mathrm{g} / \mathrm{mL}$ e anfotericina $0,025 \mu \mathrm{g} / \mathrm{mL}$ ), $2 \mathrm{mM}$ de glutamina e $10 \%$ de soro fetal bovino em incubadora úmida a $37^{\circ} \mathrm{C}$ e atmosfera de $5 \%$ de $\mathrm{CO}_{2}$ até atingirem a subconfluência (aproximadamente $90 \%$ de utilização da área de cultura) na placa de cultura, de onde foram descoladas pela ação da solução de tripsina 0,05\% / EDTA 0,02\% em solução tampão fosfato $\mathrm{pH} 7,4$. Após a tripsinização, a suspensão foi centrifugada (1500 RPM/5min) e ressuspensa em meio RPMI com 10\% de soro fetal bovino para contagem das células (câmara de Neubauer) e preparação de uma suspensão com concentração 60.000 células $/ \mathrm{ml}$.

- Preparação dos extratos

Na preparação dos extratos das amostras seguiu-se a proporção de $1 \mathrm{~cm}^{2} / 1 \mathrm{~mL}$ de meio de cultura. As amostras foram mantidas em incubadora a $37^{\circ} \mathrm{C}$, atmosfera úmida de $5 \%$ de $\mathrm{CO}_{2}$, por 48 horas. Baseado na literatura, foi utilizado como controle negativo 
titânio comercialmente puro (Ticp) denso, como controle positivo foi preparada uma solução fenol $0,3 \% \mathrm{v} / \mathrm{v}$ de meio de cultura.

Após a incubação, os extratos foram filtrados através de membrana de acetato de celulose com poros de $0,45 \mu \mathrm{m}$, e feitas diluições seriadas de $1: 2$ até $6,25 \% \mathrm{v} / \mathrm{v}$ com meio de cultura RPMI para realização do teste de viabilidade celular.

- Teste de citotoxicidade com células $\mathrm{CHO}-\mathrm{k} 1$

Para o teste de citotoxicidade, em uma placa de cultura de 96 poços foram colocados $50 \mu \mathrm{L}$ da suspensão de células $\mathrm{CHO}-\mathrm{k} 1$, na concentração final de 3000 células por poço, sobre $50 \mu \mathrm{L}$ do extrato em suas diluições, em quadruplicata. A placa foi mantida na incubadora úmida com $5 \%$ de $\mathrm{CO}_{2}$, por 72 horas, a $37^{\circ} \mathrm{C}$. A viabilidade celular foi visualizada com a adição de $20 \mu \mathrm{L}$ de solução de MTS (corante supravital de composto tetrazolico) /PMS (agente acoplador de elétrons), na razão 20:1, e incubado por mais 2 horas. Após o período de incubação, a placa foi levada a uma leitora ELISA (espectrofotômetro para leitura de placas de 96 poços) com filtro de $495 \mathrm{~nm}$ para leitura das densidades ópticas. A viabilidade celular foi determinada pela relação:

$$
V C(\%)=\left(\frac{\text { DOamostra }}{\text { DOcontrole }}\right) \times 100
$$

Onde: VC = viabilidade celular (\%); DOamostra = densidade óptica da amostra; DOcontrole $=$ densidade óptica do controle de células totais.

A concentração inibitória - $\mathrm{Cl}_{50}$, concentração do extrato que mata $50 \%$ da população de células, foi determinado graficamente.

\subsubsection{Ensaio in vivo}

\subsubsection{Implantes}

Os implantes porosos foram obtidos em formato cilíndrico, e devido às condições de processamento, as dimensões foram aproximadamente de $3 \mathrm{~mm}$ de diâmetro por 5 $\mathrm{mm}$ de comprimento, sem efetuar usinagem. Devidamente identificados e 
acondicionados, os implantes densos e porosos (de Ticp e Liga Ti-13Nb-13Zr, com adição de amido de arroz, amido de batata, amido de milho, gelatina e albumina) foram esterilizados. Os implantes de Ticp por apresentar características conhecidas de biocompatibilidade foram utilizados como grupo controle.

\subsubsection{Experimentação animal}

Dez coelhos da raça New Zealand, adultos, machos, com peso médio de $2,5 \mathrm{Kg}$ (4 meses de idade), foram designados como modelo animal neste estudo. Os animais foram alojados no biotério do IPEN, em sala climatizada com temperatura de $\sim 22{ }^{\circ} \mathrm{C}$. Os animais foram mantidos em gaiolas metálicas individuais dentro de estantes ventiladas $\mathrm{e}$ tratados com dieta à base de ração seca irradiada apropriada para coelhos e água ad libitum.

A experimentação animal seguiu os princípios éticos do Colégio Brasileiro de Experimentação Animal (COBEA). O procedimento cirúrgico é realizado seguindo estes princípios e foi aprovado pelo Comitê de Ética no Uso de Animais (CEUA) do IPEN (Parecer - Projeto nำ69/10) - Anexo I.

Como medicação anestésica para realizar o procedimento cirúrgico, foram administrados por via intramuscular: Quetamina $(30-50 \mathrm{mg} / \mathrm{kg})+$ Xilazina $(5 \mathrm{mg} / \mathrm{kg})$. O efeito anestésico para finalidade cirúrgica foi de 20 a 30 minutos e a duração da anestesia, enquanto o tempo que o animal permaneceu sedado foi de aproximadamente 120 minutos, após o acompanhamento e medicações pós-cirúrgicas o animal foi colocado de volta à sua gaiola. $\mathrm{O}$ anestésico local administrado na área cirúrgica foi o Cloridrato de lidocaína sem vaso constritor a 3\%, em tubetes de 1,8ml. Após a cirurgia foi administrado em dose única Pentabiótico® intramuscular ( $1 \mathrm{~mL} /$ animal) e três doses consecutivas de 24 em 24 horas de Cloridrato de Tramadol $(3 \mathrm{mg} / \mathrm{kg})$ com a finalidade de promover analgesia e Cetoprofeno $(3 \mathrm{mg} / \mathrm{kg})$ para ação anti-inflamatória diminuindo o estresse e a dor pós-cirurgia, melhorando o bem-estar dos animais.

Primeiramente, a região da tíbia proximal dos animais foi tricomizada e realizada a antissepsia com gluconato de clorhexidina a $2 \%$ e iodopovidona. Em seguida, foi realizada incisão nos tecidos moles, com cabo de bisturi ( $\left.n^{\circ} 3\right)$ munido de lâmina 15 , de forma que a incisão seja retilínea de movimento único, paralelamente ao longo eixo da porção medial da tíbia. O descolamento do periósteo foi realizado com objetivo de proporcionar o acesso e visão à área operatória. A localização do leito cirúrgico foi na porção medial da tíbia, na região entre epífise e diáfise. 
O leito de inserção dos implantes foi preparado com a utilização de trefinas ( $\Phi 2$ mm) e brocas esféricas acopladas a contra-ângulo com redução de 16:1, movido por motor elétrico com velocidade de $454 \mathrm{rpm}$ e $55 \mathrm{~N} . \mathrm{cm}$ de torque, sob constante irrigação (solução isotônica de cloreto de sódio a 0,9\%) e monitoramento da temperatura por termômetro de infravermelho. Após a instalação dos implantes, o periósteo foi suturado com fios de sutura mononylon 5.0 com ponto simples contínuo, a pele foi suturada com ponto em "U" (imbricação lateral) contínuo. Após a sutura da pele, a mesma foi limpa com antisséptico e a região da sutura recebeu pomada Nebacetin® e bandagem protetora com micropore.

Os animais foram acompanhados por 7 semanas para a avaliação da osteointegração do osso em relação aos implantes. Com o intuito de acompanhar o processo de formação óssea, foram aplicados marcadores ósseos fluorocromáticos. Cada marcador foi administrado (subcutaneamente) uma vez por semana durante duas semanas consecutivas, na ordem: Tetraciclina $(60 \mathrm{mg} / \mathrm{Kg})$, Alizarina $(30 \mathrm{mg} / \mathrm{Kg})$ e Calceína $(10 \mathrm{mg} / \mathrm{Kg})$. Totalizando 49 dias de experimentação até a eutanásia dos animais. Os marcadores celulares ósseos apresentam-se na forma de pó, necessitando de diluição. Os pós são pesados em balança de precisão e diluídos em $1 \mathrm{~mL}$ de soro fisiológico com $2 \mathrm{mg}$ de $\mathrm{Na}_{2} \mathrm{HPO}_{4}$.

Os animais foram eutanasiados seguindo a sequência: anestesia geral do animal em plano profundo (Quetamina 30-50 mg/kg + Xilazina $10 \mathrm{mg} / \mathrm{kg}$ ), injeção intravenosa de cloreto de potássio $(35 \mathrm{mg} / \mathrm{kg}$ ) com a finalidade de parada das funções vitais.
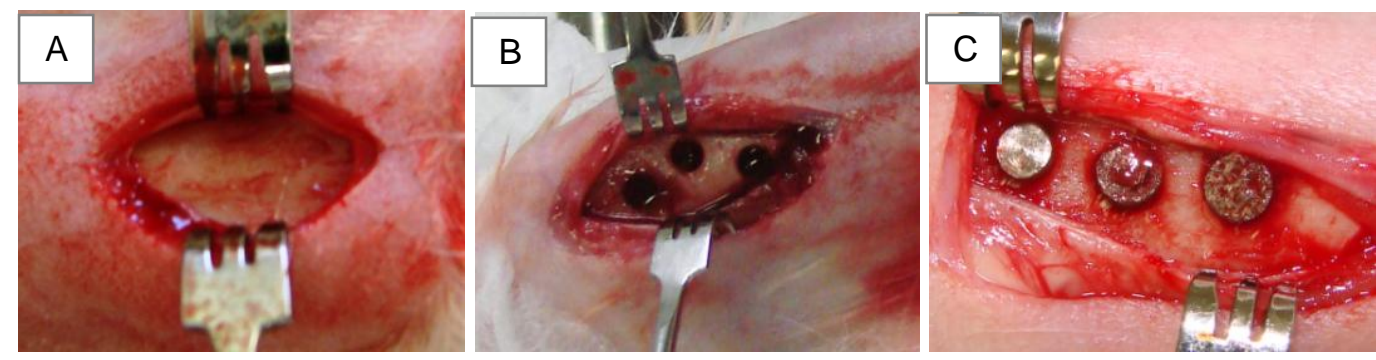

Figura 14. Etapas do procedimento cirúrgico: A) acesso cirúrgico ao osso, B) perfurações com broca trefina, C) colocação dos implantes. 

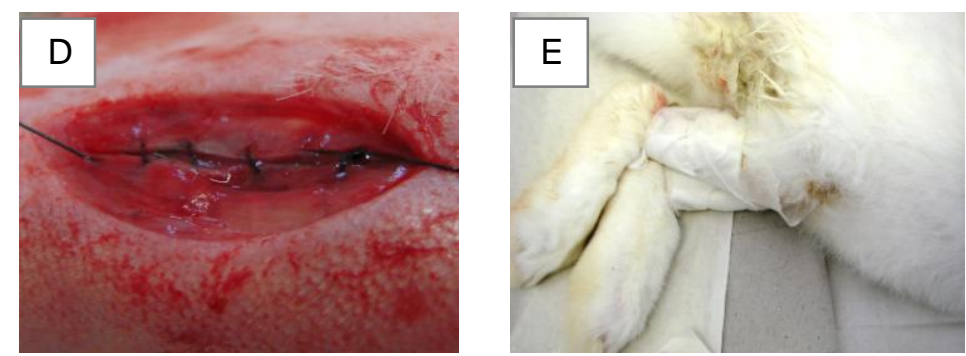

Figura 15. Etapas do procedimento cirúrgico: A) sutura do periósteo previamente à sutura em pele, B) curativo no pós-operatório.

\subsubsection{Análise histológica}

Os tecidos moles foram dissecados e os conjuntos contendo osso e implante, foram removidos, com o auxílio de disco diamantado e micromotor elétrico, e foram mantidos imersos em solução de formalina a $10 \%$, durante 30 dias. $O$ procedimento de inclusão das amostras segue o protocolo da Resina Technovit® 9100 NEU até a etapa de obtenção das lâminas (Anexo II).

Para a etapa de obtenção das lâminas histológicas, o conjunto osso-implante embutido em resina, foi fixado em uma máquina de corte (Isomet 2000) de modo que o disco diamantado ficasse posicionado transversalmente ao longo eixo do osso. Nos cortes obtidos foi possível observar todo o longo eixo do implante e a transversal óssea, tendo uma visão geral da superfície e da parte mais central do implante, detalhe importante na avaliação dos materiais porosos, a representação do corte está presente na Figura 16.

Cada corte foi obtido com aproximadamente $500 \mu \mathrm{m}$ de espessura e colocados individualmente em lâminas de vidro utilizando uma gota de cianoacrilato (SuperBonder ${ }^{\circledR}$, Loctite, Brasil), com pressão constante. Foi necessário o desgaste dos cortes até a espessura de aproximadamente $30 \mu \mathrm{m}$ para a avaliação histológica. Lixas de carbeto de silício (granulometria 800, 1000, 1200, 2400, 4000 mesh) foram utilizadas neste processo para o desbaste e polimento. 


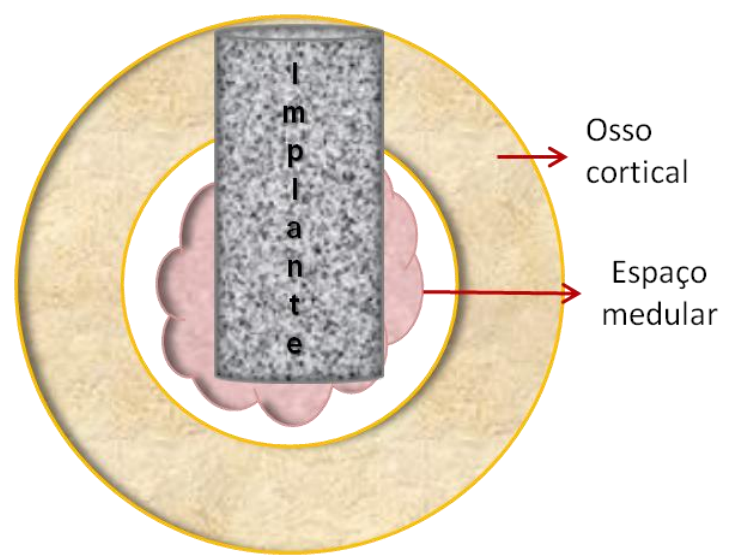

Figura 16. Representação esquemática do corte histológico.

A análise por microscopia de fluorescência foi realizada a partir dessas lâminas histológicas sem coloração. Cada imagem foi fotografada em coloração monocromática com três diferentes filtros: D, N2.1 e 13, respectivamente para os marcadores ósseos tetraciclina, alizarina e calceína. As imagens foram captadas no microscópio Leica DM2500 com câmera digital acoplada Leica DFC310FX em tons de cinza, monocromático. A análise qualitativa procedeu-se com a sobreposição das imagens obtidas individualmente para cada filtro, no programa ImagePro Plus 6.1 cada imagem foi colorida com a cor verde representando a calceína, vermelho representando a alizarina e o azul representando a tetraciclina. A presença das cores amarela, magenta, ciano e branco são resultantes da combinação das cores primárias atribuídas a cada filtro usado, sendo o amarelo da combinação de verde com o vermelho, o magenta da combinação de vermelho com o azul, o ciano da combinação de azul com o verde e o branco da combinação das três cores primárias, vermelho, verde e azul.

Um corte do conjunto osso-implante embutido em resina, de cada amostra do grupo experimental foi separada para a análise da integração óssea com o implante. A técnica de EDS - MEV (Tabletop) proporciona uma análise quantitativa da porcentagem em massa dos elementos que compõem a amostra nas regiões observadas. Imagens em aumento de 400x foram selecionadas para cada amostra. Nas amostras de Ticp foram identificados os elementos $\mathrm{Ti}$, Ca e P (Figura 17); e nas amostras da Liga foram identificados elementos constituintes dos implantes como o $\mathrm{Ti}, \mathrm{Nb}$ e $\mathrm{Zr}$, e elementos que compõem o tecido ósseo (Ca e P) (Figura 18). Para a análise de ambos os grupos foram padronizados e utilizados apenas os elementos Ti e Ca. 

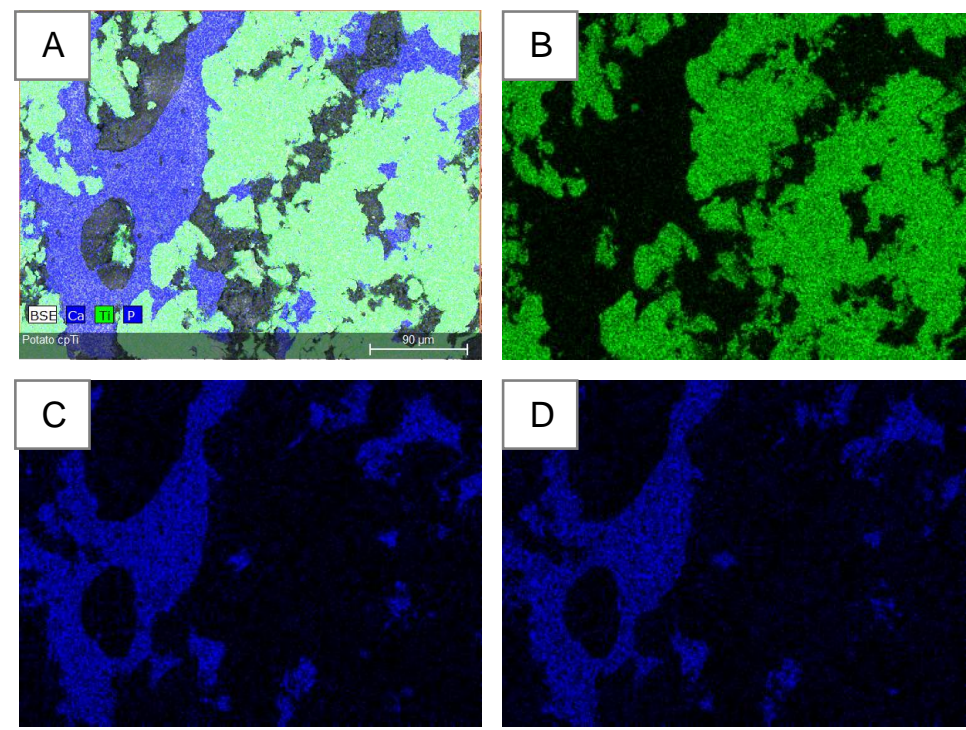

Figura 17. Exemplo de análise em MEV/EDS de amostra do grupo de Ticp: A) imagem composta marcando $\mathrm{Ti}$, $\mathrm{Ca}$ e $\mathrm{P}$; B) imagem marcando somente áreas com $\mathrm{Ti}$; $\mathrm{C}$ ) marcação de Ca; D) marcação de $P$.
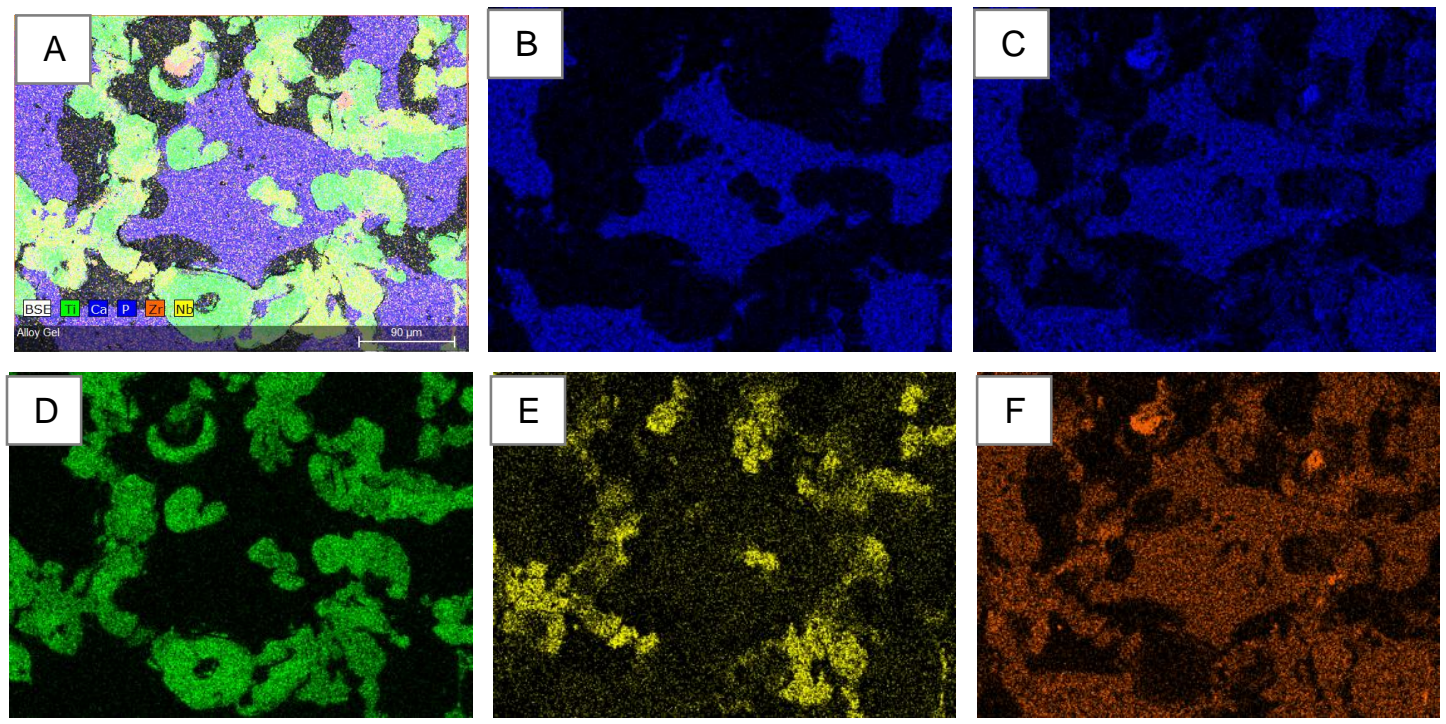

Figura 18. Exemplo de análise em MEV/EDS de amostras do grupo de Liga: A) imagem composta marcando $\mathrm{Ca}, \mathrm{P}$; $\mathrm{Ti}$, Nb e Zr; B) marcação de $\mathrm{Ca}$; C) marcação de $\mathrm{P}$; D) marcação de Ti; E) marcação de Nb e F) marcação de Zr.

Nas mesmas imagens foram quantificadas a área do implante, do osso e poro não preenchido. Essa seleção foi realizada manualmente para cada imagem com uso do software ImagePro Plus 6.1. Os resultados estão apresentados na forma de gráfico (Figura 19). 


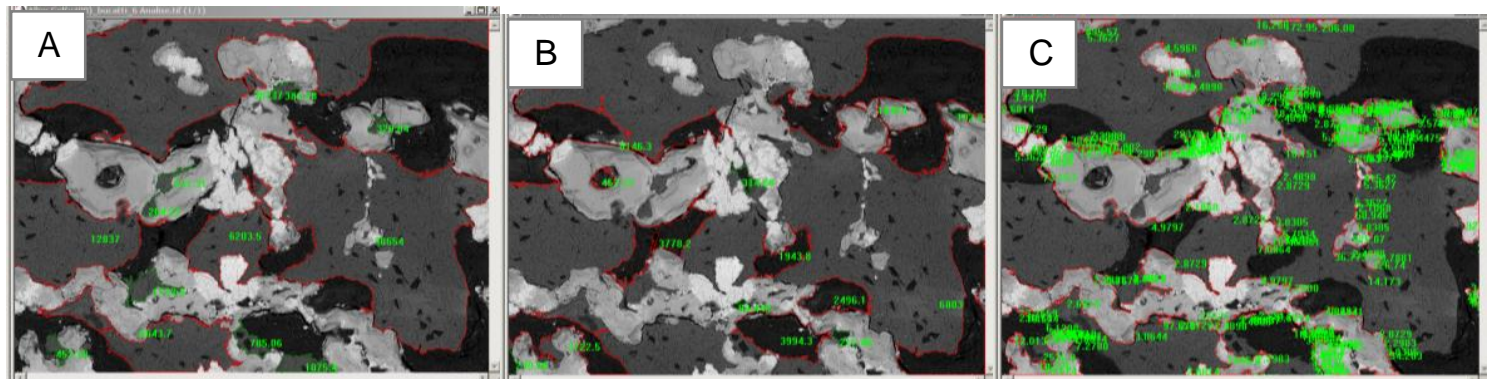

Figura 19. Exemplo de análise de imagem quantitativa da relação osso/implante: A) demarcação de osso, B) demarcação de poros e C) demarcação de implante. 
Resultados e Discussão

A apresentação dos resultados deste estudo envolve caracterização dos materiais particulados, processamento e caracterização de materiais porosos sinterizados, teste de toxicidade in vitro dos materiais desenvolvidos, finalizando com a avaliação da osteointegração dos materiais porosos, em teste in vivo. 


\section{RESULTADOS E DISCUSSÃO}

\subsection{Caracterização do material particulado}

Em metalurgia do pó (MP), a morfologia e a granulometria do pó utilizado é muito importante para o processo de compactação e sinterização. O formato das partículas próximo ao esférico facilita o escorregamento entre elas durante o processo de compactação, elevando o grau de empacotamento das partículas. Consequentemente existe um aumento no contato direto entre as partículas, otimizando o transporte de massa durante a sinterização. O tamanho da partícula, também está relacionado com a otimização do processo, quanto menor o tamanho de partícula, melhor é a difusibilidade durante a sinterização ${ }^{56}$.

Para o processamento das amostras de Ticp foi utilizado como material de partida pó de $\mathrm{TiH}_{2}$. $\mathrm{Na}$ caracterização do pó foi observada por microscopia eletrônica de varredura (MEV), a morfologia das partículas, estas são bastante irregulares (Figura 20). Para determinar as fases cristalinas da matéria prima, foi realizada análise por difração de raios $X(D R X)$, constatando-se apenas a fase $\mathrm{TiH}_{2}$ (JCPDS $\mathrm{n}^{\circ}$ 25-0982) (Figura 20). Quanto à distribuição granulométrica, o diâmetro médio de partículas foi de $43 \mu \mathrm{m}$ (Figura 24).

No processamento da Liga Ti-13Nb-13Zr foram utilizados pós metálicos de titânio (Ti), nióbio $(\mathrm{Nb})$ e zircônio $(\mathrm{Zr})$. Por microscopia eletrônica de varredura (MEV) foi possível observar o formato bastante irregular e elevada rugosidade das partículas de $\mathrm{Ti}$ (Figura 21), com formas mais arredondadas do que as partículas de $\mathrm{Nb}$ (Figura 22), que apresentam ângulos vivos. As partículas de Zr são as que mais se aproximam do formato esférico (Figura 23). A distribuição granulométrica dos diversos materiais é apresentada na Figura 24, o Ti possui diâmetro médio de $\sim 120 \mu \mathrm{m}$, o Nb $\sim 36 \mu \mathrm{m}$. E as partículas de $\mathrm{Zr}$ são bem menores com o tamanho médio de $\sim 5,5 \mu \mathrm{m}$, ele é armazenado em meio líquido devido à sua elevada reatividade, sendo pirofórico quando em partículas pequenas. 

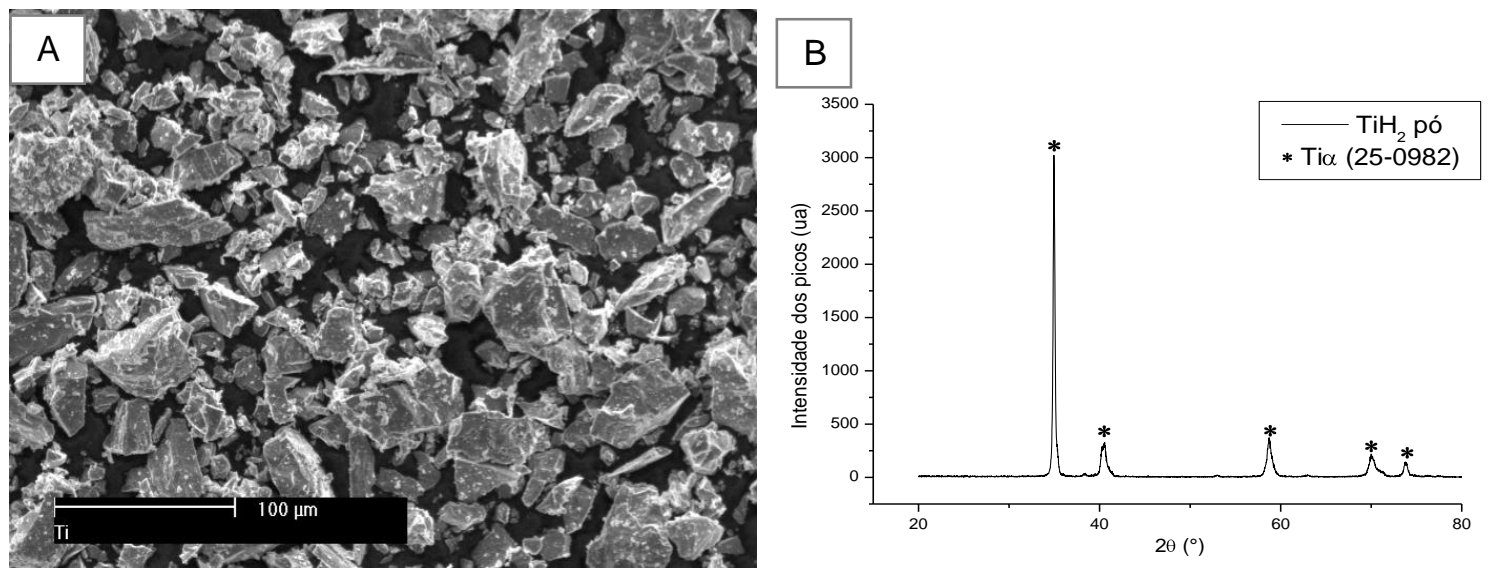

Figura 20. Pó de $\mathrm{TiH}_{2}$ : A) MEV mostrando a morfologia bastante irregular das partículas com ângulos vivos; B) DRX constatando apenas a fase cristalina cúbica de face centrada 83.
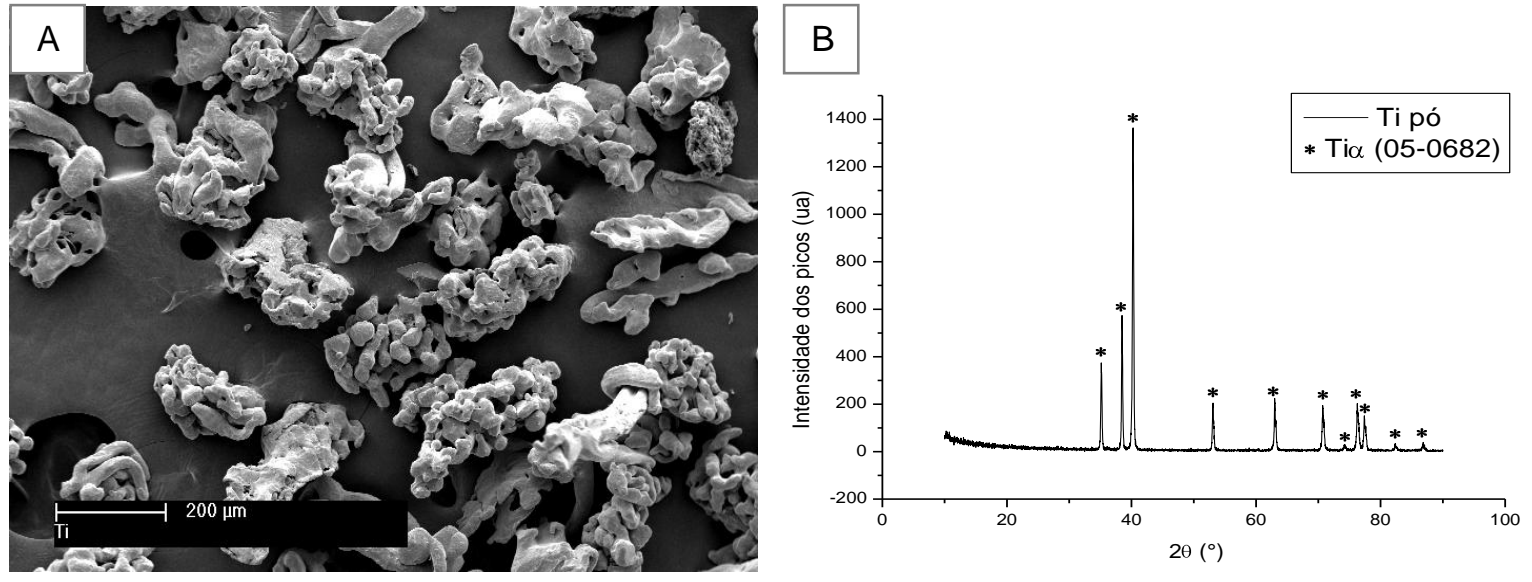

Figura 21. Pó de Ti: A) MEV mostrando a morfologia bastante irregular das partículas com elevada rugosidade; B) DRX constatando apenas a fase cristalina hexagonal compacta.
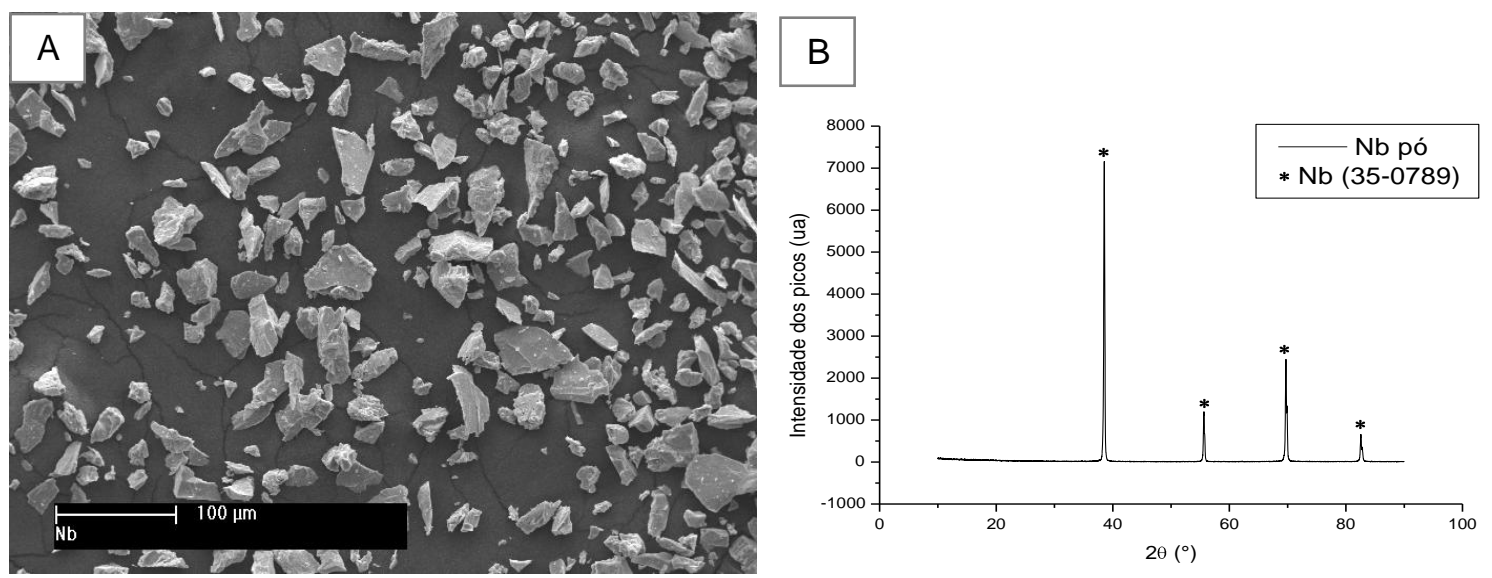

Figura 22. Pó do $\mathrm{Nb}$ : A) MEV mostrando a morfologia bastante irregular das partículas com ângulos vivos; B) DRX constatando apenas a fase cristalina cúbica de corpo centrado. 

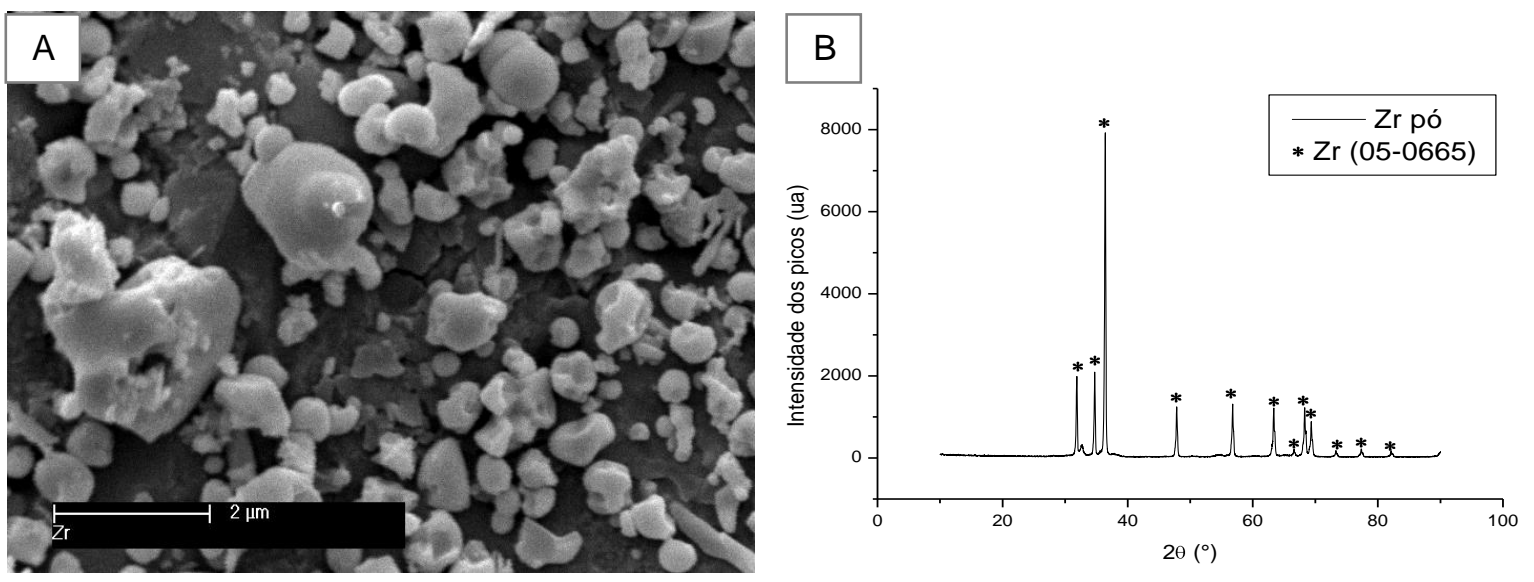

Figura 23. Pó do Zr: A) MEV mostrando a morfologia próxima do formato esférico; B) DRX constatando apenas a fase cristalina hexagonal compacta.

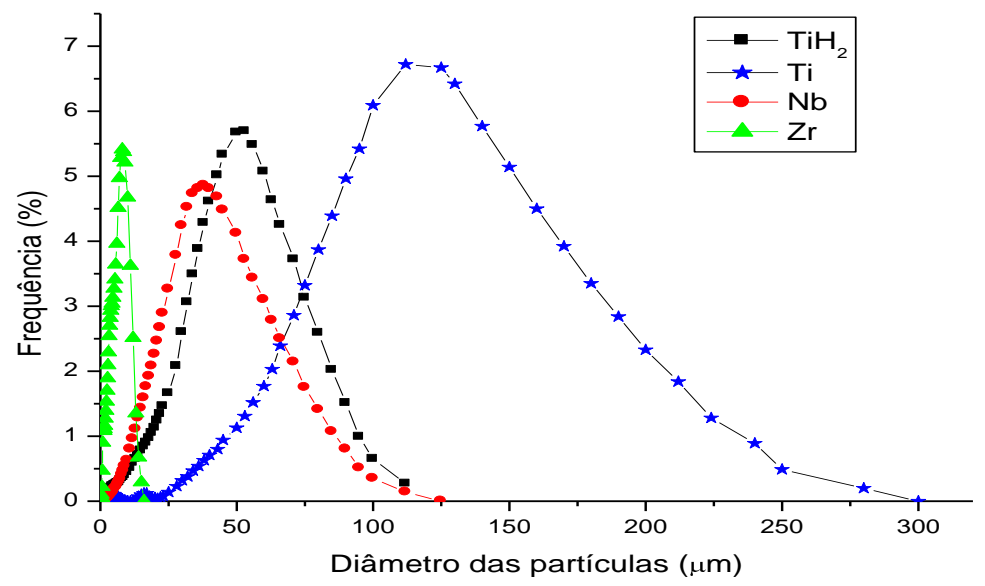

Figura 24. Distribuição do tamanho de partícula dos pós de partida: $\mathrm{TiH}_{2}(43 \mu \mathrm{m}), \mathrm{Ti}$ (120 $\mu \mathrm{m}), \mathrm{Nb}(36 \mu \mathrm{m})$ e $\mathrm{Zr}(5,5 \mu \mathrm{m})$.

A metodologia utilizada neste estudo para obtenção de materiais porosos tem como princípio a formação de poros pela degradação do material orgânico adicionado no processamento. Para a efetiva formação dos poros pela degradação do material orgânico é necessário realizar tratamento térmico em atmosfera oxidante, removendo os polímeros naturais adicionados, na forma de $\mathrm{CO}_{2}$ (Figura 25) antes da sinterização em vácuo. Assim é necessário avaliar o comportamento de cada material de partida em relação à temperatura. 


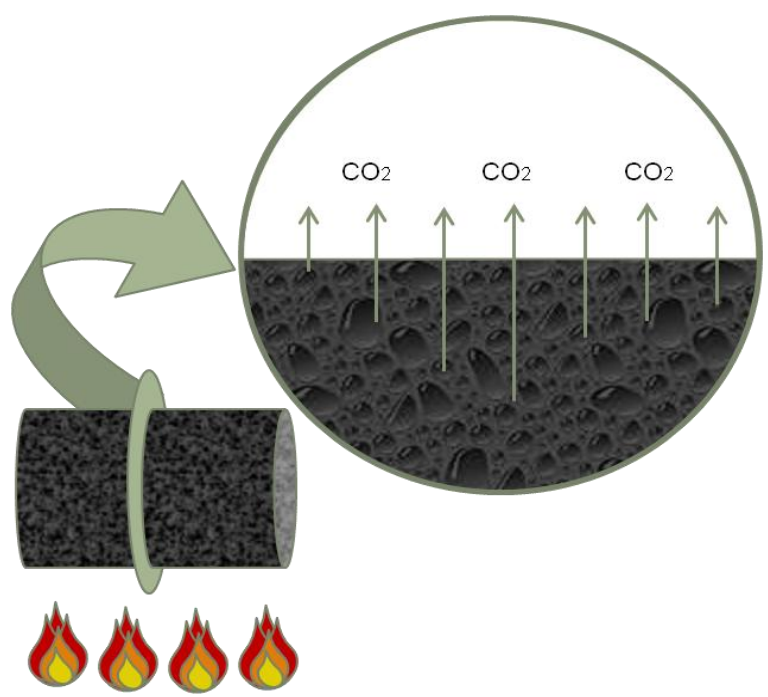

Figura 25. Desenho esquemático do processo de remoção do material orgânico sob forma de $\mathrm{CO}_{2}$ durante tratamento térmico em atmosfera oxidante.

Os comportamentos dos pós metálicos e do hidreto de titânio foram analisados por análise termogravimétrica, pois o aumento da temperatura em atmosfera oxidante propicia a oxidação dos metais. As análises foram feitas com taxa de aquecimento de $10^{\circ} \mathrm{C} / \mathrm{min}$ até $1000^{\circ} \mathrm{C}$, em atmosfera oxidante. A oxidação do Ti metálico tem início a $\sim 500^{\circ} \mathrm{C}$, o que pode ser observado pelo ganho de massa com a elevação da temperatura (Figura 26 A). $\mathrm{O}$ material particulado de $\mathrm{TiH}_{2}$ apresenta maior estabilidade do que $\mathrm{Ti}$, por estar na forma de hidreto. A partir de $\sim 600^{\circ} \mathrm{C}$ tem início a dehidrogenação do metal ${ }^{45}$, com a saída do hidrogênio da estrutura cristalina, ocorre a oxidação (Figura 26 B). O Nb apresenta-se estável em relação ao ganho de massa até aproximadamente $500^{\circ} \mathrm{C}$, tendo um ganho expressivo nessa temperatura. Essa característica indica que tratamento térmico até $500^{\circ} \mathrm{C}$ não interfere na oxidação do metal, proporcionando uma faixa de temperatura bem específica (Figura $26 \mathrm{C}$ ). No entanto, para o particulado fino de Zr, já a $\sim 300^{\circ} \mathrm{C}$ tem inicio a oxidação, isso é devido às partículas com área superficial elevada possuírem maior reatividade (Figura $26 \mathrm{D})$. 

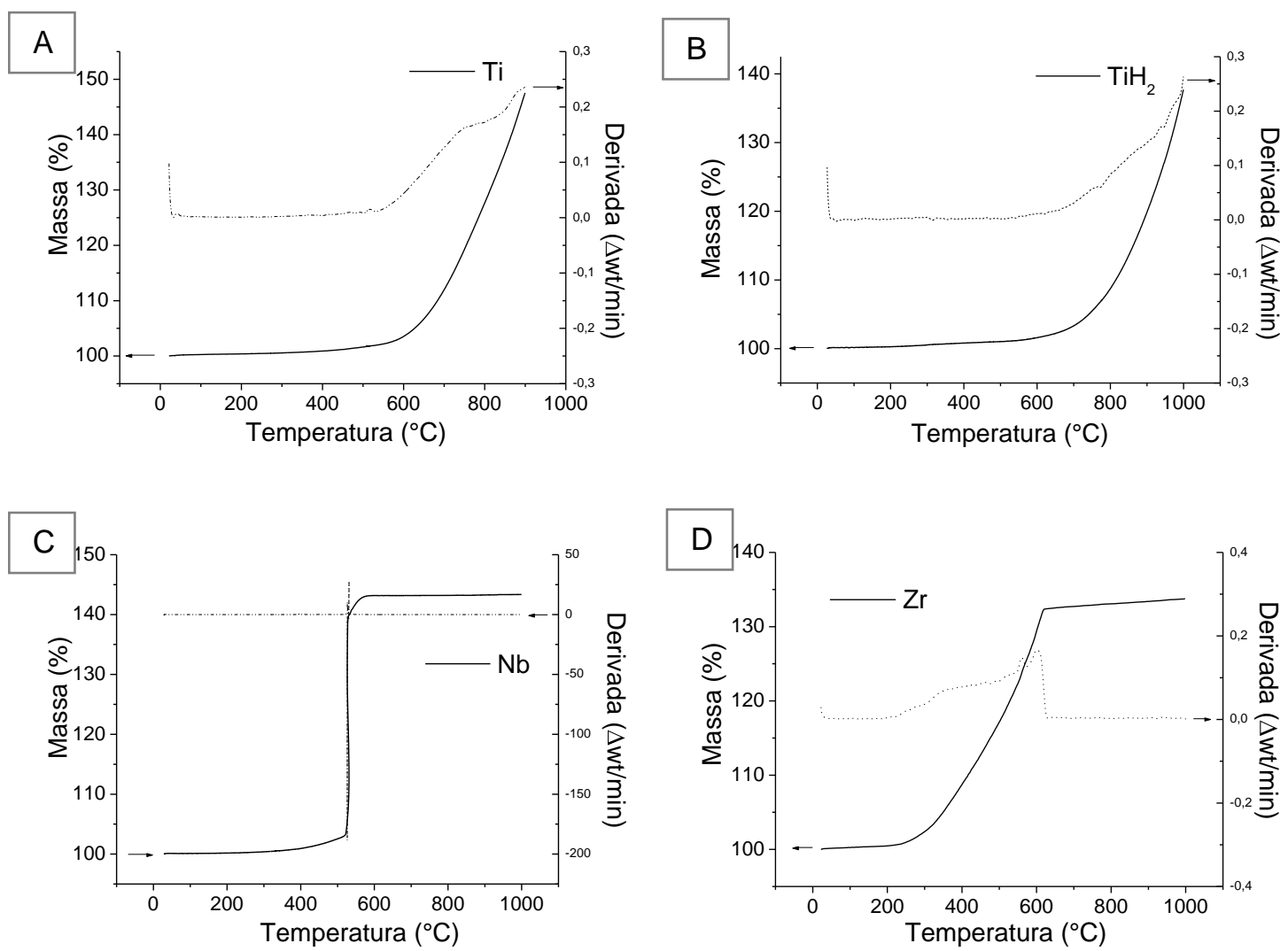

Figura 26. Análise termogravimétrica (TG) e derivada (DTG) dos materiais particulados: A) $\mathrm{Ti}$, B) $\mathrm{TiH}_{2}$, C) $\mathrm{Nb}$ e D) $\mathrm{Zr}$.

Análise termogravimétrica também foi realizada para os polímeros naturais, com taxa de aquecimento de $10^{\circ} \mathrm{C} / \mathrm{min}$ até $800^{\circ} \mathrm{C}$, em atmosfera oxidante. Em todas as análises foi possível observar dois estágios principais de perda de massa. O primeiro, relacionado à perda de água livre contida no material que ocorre em até $\sim 100^{\circ} \mathrm{C}$, com $\sim 10 \%$ da perda de massa. O segundo estágio refere-se à perda de água estrutural e decomposição do material orgânico, no qual cada polímero apresenta um comportamento diferente.

O comportamento dos amidos de milho, arroz e batata podem ser observados nos gráficos da Figura 27 (A, B e C), há mais de $70 \%$ da perda de massa até $\sim 350^{\circ} \mathrm{C}$. No gráfico da Figura $27 \mathrm{D}$, a perda de massa para a gelatina é expressiva entre $300^{\circ} \mathrm{e}$ $400^{\circ} \mathrm{C}$, sendo a maior taxa em $350^{\circ} \mathrm{C}$. A albumina (Figura $27 \mathrm{E}$ ) tem um comportamento diferente em relação aos outros polímeros naturais estudados; a curva termogravimétrica apresenta 3 estágios de perda de massa, o terceiro estágio ocorre em $\sim 600^{\circ} \mathrm{C}$ consumindo todo o material. Foi observada durante o ensaio a formação de uma 
"caramelização" da superfície da albumina que impede a liberação da massa na forma de $\mathrm{CO}_{2}$. A partir de $\sim 530^{\circ} \mathrm{C}$, essa camada se rompe permitindo a liberação dos gases.
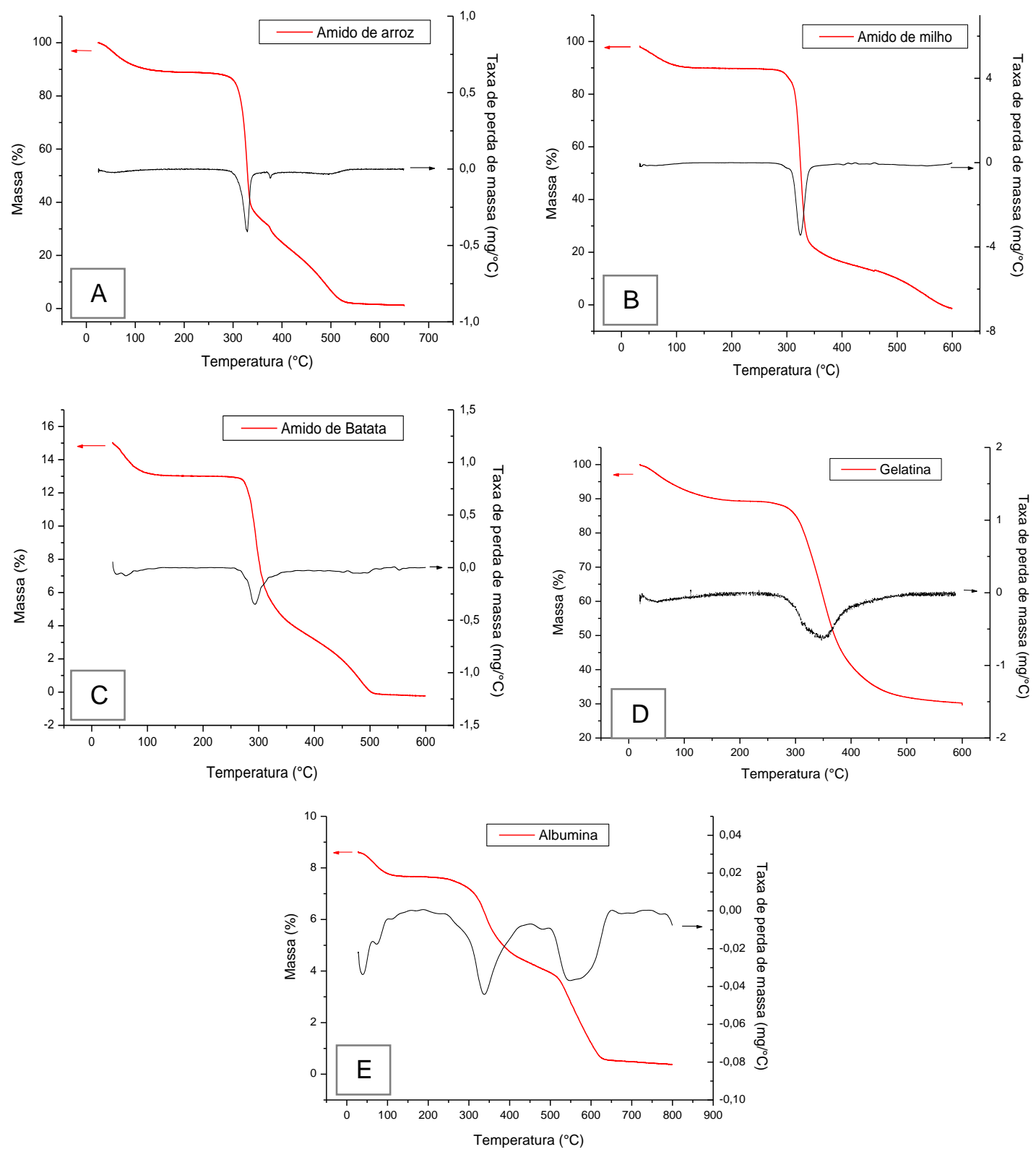

Figura 27. Análise termogravimétrica (TG) e derivada (DTG) dos polímeros naturais: A) amido de arroz, B) amido de milho, C) amido de batata, D) gelatina e E) albumina.

Com base nos resultados obtidos por análise termogravimétrica, após a conformação, as amostras foram tratadas termicamente a $350^{\circ} \mathrm{C}$, por 1 hora, taxa de aquecimento e resfriamento de $1^{\circ} \mathrm{C} / \mathrm{min}$, em atmosfera oxidante.

A granulometria dos polímeros naturais foi avaliada (Figura 28). O tamanho médio de partícula dos amidos de arroz $(\sim 11 \mu \mathrm{m})$ e milho $(\sim 16 \mu \mathrm{m})$ pode ser considerado 
semelhante, e bem inferior ao valor médio de diâmetro de partícula do amido de batata $(\sim 55 \mu \mathrm{m})$. A granulometria da albumina segue a mesma faixa do amido de batata $\sim 45$ $\mu \mathrm{m}$. A gelatina destaca-se dos demais polímeros naturais com o tamanho médio de partícula $\sim 225 \mu \mathrm{m}$.

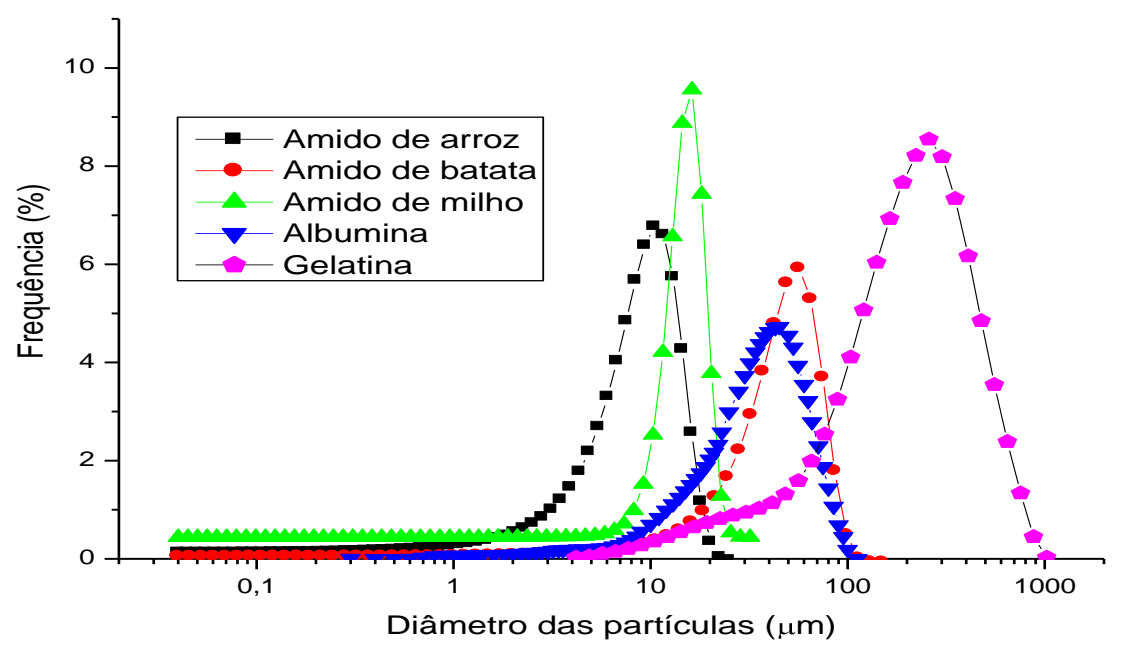

Figura 28. Distribuição do tamanho de partícula dos polímeros naturais: amidos de arroz $(11 \mu \mathrm{m})$, amido de milho $(16 \mu \mathrm{m})$, amido de batata $(55 \mu \mathrm{m})$, albumina $(45 \mu \mathrm{m})$ e gelatina $(225 \mu \mathrm{m})$.

\subsection{Grupo controle - denso}

A avaliação da resposta do tecido ósseo em relação aos materiais porosos deve ter como referência materiais com comportamento ósseo conhecido, como implantes de Ticp densos usinados. Sabe-se que a topografia do implante é um fator que influencia diretamente a qualidade da osteointegração. Com a finalidade de comparação da topografia das amostras porosas obtidas, foram usinadas amostras densas utilizadas como grupos controle neste estudo, representando a maioria dos implantes comerciais. As amostras densas foram obtidas por metalurgia do pó, que consiste na prensagem e sinterização do particulado. A superfície das amostras sinterizadas apresenta elevada rugosidade inerente ao processamento (Figura 29A). O processo de usinagem resultou em superfícies lisas como pode ser observado nas Figura 29B e Figura 29C. 

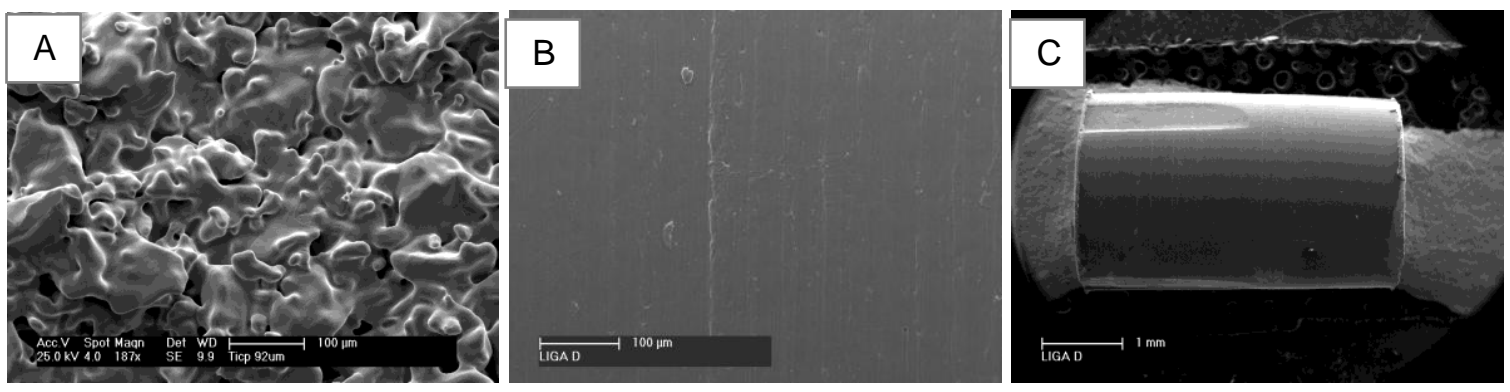

Figura 29. MEV da superfície do implante denso: A) topografia após sinterização, B) e C) topografia após usinagem do implante denso.

A microestrutura foi observada em cortes transversais das amostras de Ticp, observando-se o isolamento e o arredondamento dos poros entre os contornos de grão, o que ocorre na fase final da sinterização. A formação de porosidade fechada, distribuída homogeneamente, é o resultado esperado do processamento por metalurgia do pó (Figura 30 A e B). As amostras de Liga são mais porosas (9\%) do que as amostras de Ticp (1\%), essa diferença pode ser decorrente da diferença de tamanho médio de partícula dos pós utilizados, o pó de $\mathrm{TiH}_{2}$ é quase três vezes menor que o pó de $\mathrm{Ti}$ utilizado na liga. Pós mais grosseiros são mais fáceis de serem compactados, mas a densificação é mais difícil de ser alcançada, necessitando de maior temperatura de tratamento térmico ou maior tempo de patamar. Outro aspecto a ser discutido é o formato das partículas, que apesar de irregulares, as partículas de Ti apresentam a superfície muito mais rugosa (Figura 21). Por análise de imagem é possível observar a microestrutura das amostras de Liga Ti-13Nb-13Zr, com formação da estrutura Widmanstatten, que representa a homogeneidade estrutural com a formação da fase $\alpha$ na matriz $\beta^{51}$ (Figura 31B). A boa homogeneidade estrutural pode ser atribuída ao aumento no tempo de patamar ( 3 horas), pois tempos menores de patamar não permitiram a formação de solução sólida completa. Os elementos $\beta$ estabilizadores apresentam tamanho médio de partículas bem inferior ao Ti, a ampla faixa de distribuição granulométrica pode ter proporcionado às partículas mais finas ocuparem os espaços entres as partículas maiores, otimizando a compactação e a difusibilidade dos elementos da Liga Ti-13Nb-13Zr. A análise por DRX complementa as informações relacionadas às estruturas cristalinas, tendo-se apenas a fase $\alpha$ nas amostras de Ticp e as fases $\alpha$ e $\beta$ nas amostras de Liga Ti-13Nb-13Zr (Figura 32). 

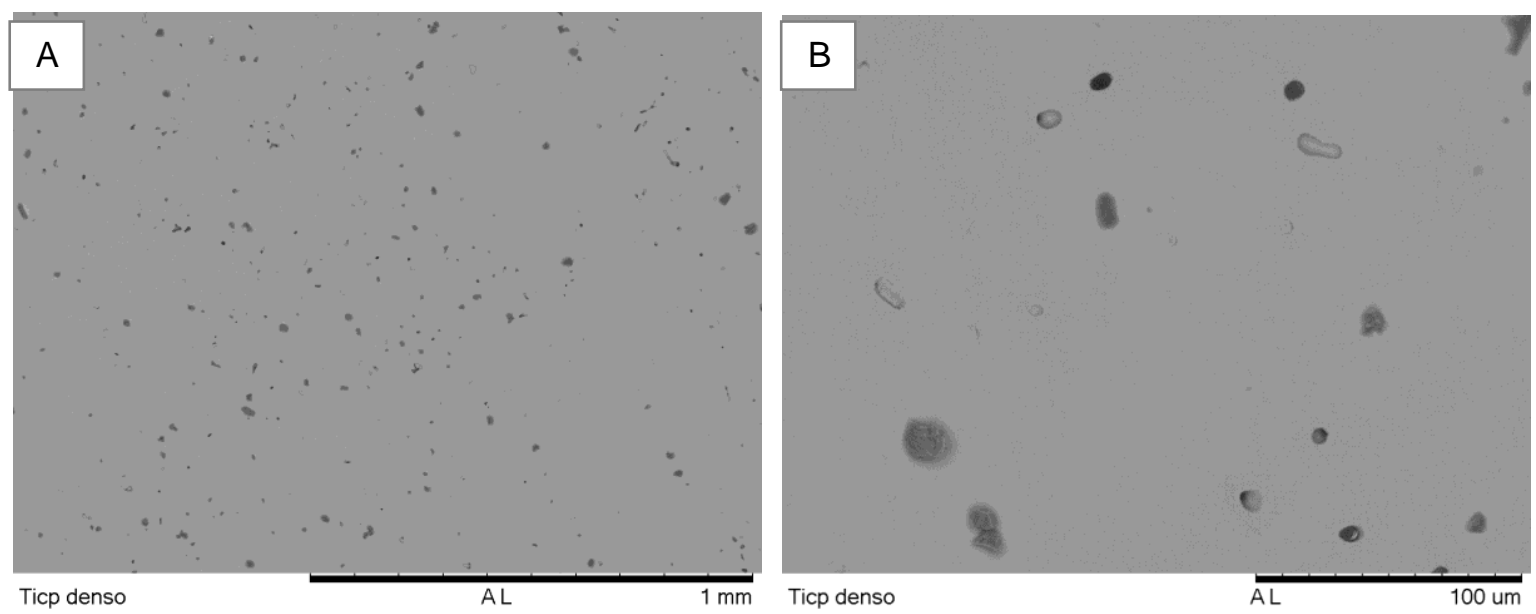

Figura 30. MEV da microestrutura da secção transversal e polida da amostra de Ticp denso: A) observa-se a homogeneidade na distribuição dos poros na microestrutura, B) poros com formato esférico.
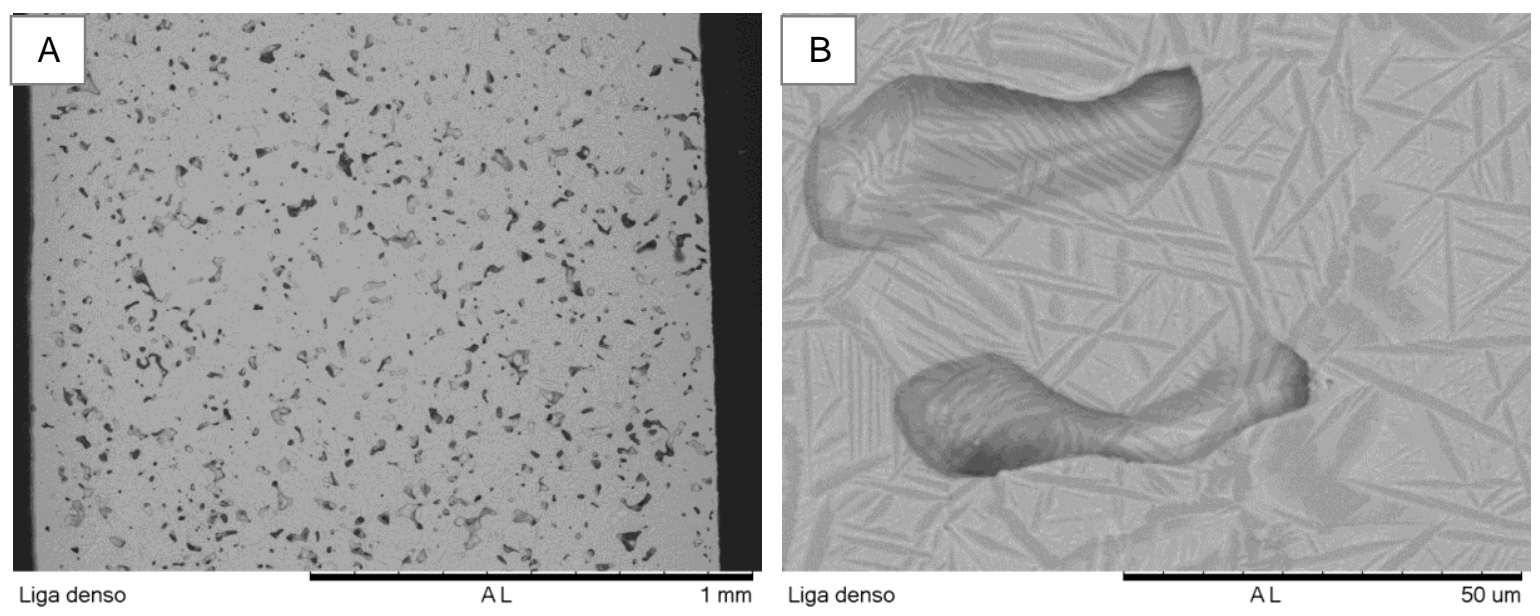

Figura 31. MEV da microestrutura da secção transversal e polida da amostra da Liga densa: A) observa-se a homogeneidade na distribuição dos poros na microestrutura, B) poros com formato alongado e arredondado.
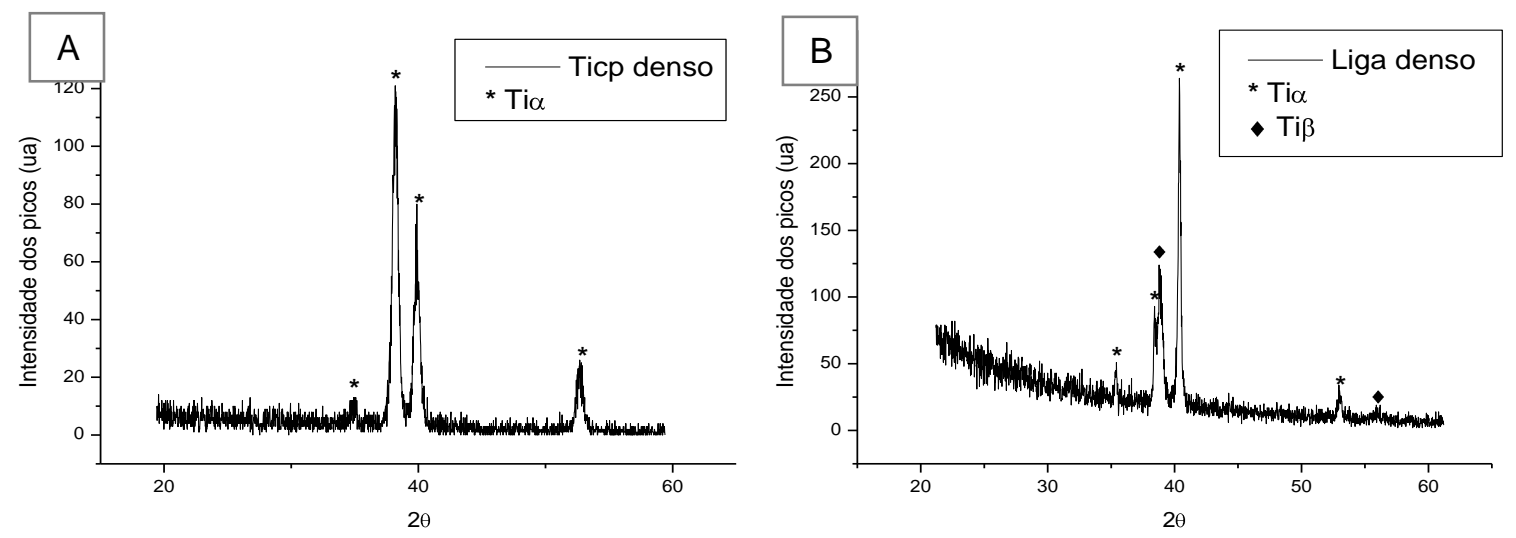

Figura 32. DRX das amostras densas: A) Ticp, presença apenas da fase $\alpha$; B) Liga, presenças das fases $\alpha$ e $\beta$. 
5.3. Metodologia para obtenção dos materiais porosos à base de titânio

Para definir a metodologia de obtenção dos materiais porosos foi realizado um estudo preliminar, no qual, foram avaliadas variáveis como técnica de processamento, polímero natural utilizado, razão entre metal e polímero natural. A partir da caracterização dos materiais obtidos foram definidos os processos de processamento de amostras que mantivessem a integridade, com alta porosidade e poros com diferentes distribuições dimensionais. As metodologias testadas foram: técnica do "space-holder" e suspensão; e os polímeros naturais utilizados foram: amido de arroz, amido de batata, amido de milho, gelatina, albumina e alginato.

Pela técnica do "Space-Holder" foram testadas a adição de 10, 20 e 30\% em peso de polímero natural, para obtenção de amostras. Homogeneizados o pó de $\mathrm{TiH}_{2}$ e o polímero natural nas proporções selecionadas, as amostras foram prensadas, tratadas termicamente $\left(350^{\circ} \mathrm{C} / 1\right.$ hora $)$ e sinterizadas $\left(1300^{\circ} \mathrm{C} / 1\right.$ hora $)$. Com $10 \%$ de adição em peso, todos os polímeros estudados permitiram o término do processo com êxito, mantendo a estrutura e forma desejada em todas as etapas, com integridade ao manuseio, ou seja, após a prensagem, tratamento térmico e sinterização. Com adições de $20 \%$ em peso de polímero natural, apenas as amostras com amido de milho e de arroz e com albumina, mantiveram o formato desejado, possuindo condições de prosseguir com o processamento após tratamento térmico. A proporção de $30 \%$ em peso foi excessiva para quase todos os polímeros, com exceção da albumina que permitiu manter o formato íntegro, após tratamento térmico. A Figura 33A ilustra a forma da amostra com adição de $30 \%$ de amido de milho após a prensagem à verde, e a Figura 33B representa a deformação da amostra, após o tratamento térmico. As formulações das amostras, que apresentaram aspecto deformado, após o tratamento térmico, foram descartadas do estudo.
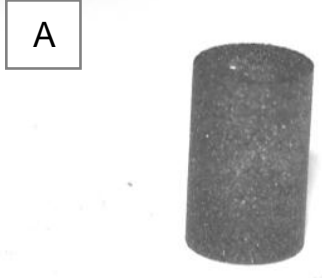
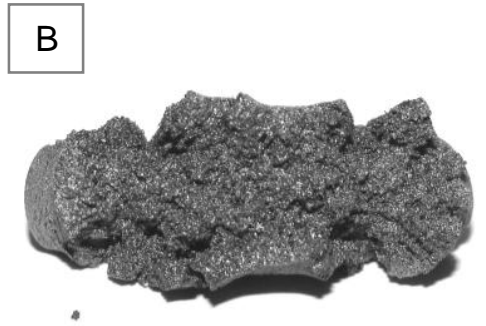

Figura 33. Amostra com adição de 30\% em peso de amido de milho, pela técnica "SpaceHolder": A) amostra após prensagem, B) amostra após tratamento térmico. 
A perda de massa das amostras foi avaliada em todos os grupos estudados, sendo esta perda proporcional à porcentagem em peso de polímero adicionado. Amostras com adição de 20 e 30\% de orgânico tiveram a perda de massa limitada durante o tratamento térmico tendo expressiva perda de massa durante a sinterização (Figura 34).

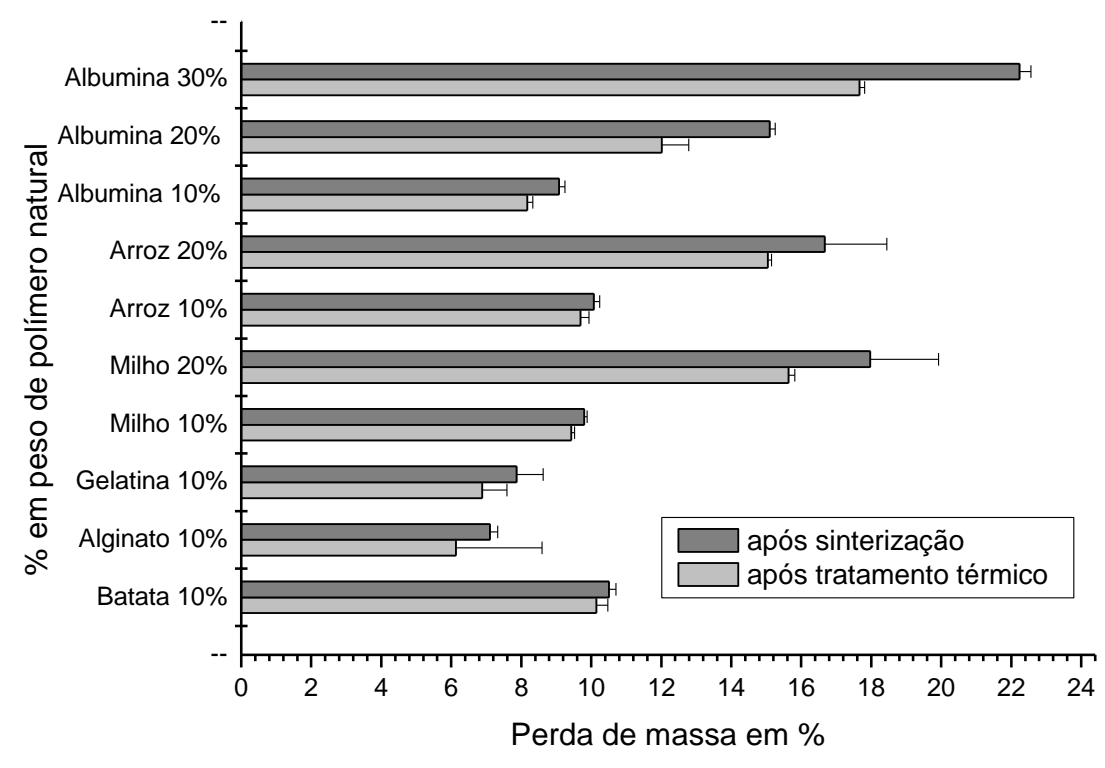

Figura 34. Perda de massa (em \%) das amostras obtidas por "space-holder" após tratamento térmico e sinterização, em relação ao peso inicial das amostras.

A porosidade das amostras dos grupos estudados, após a sinterização, é visualizada na Tabela 2. Os polímeros que apresentaram melhores resultados para obtenção de materiais de porosidade elevada, quando adicionados $10 \%$ em relação ao peso, foram a albumina e o alginato. A adição de $20 \%$ do amido de milho, do amido de batata e albumina permitiu a formação de estrutura bem porosa. O único polímero natural que adicionado em proporções de até $30 \%$, que permitiu a manutenção da forma das amostras após tratamento térmico foi a albumina. As amostras com adições de albumina, não apresentaram valores coerentes da proporção de polímero e os valores das porosidades finais. Assim, foram estudadas as densidades obtidas em função da pressão aplicada durante a prensagem uniaxial. Os grupos analisados foram submetidos à prensagem uniaxial sob pressão de $\sim 440 \mathrm{MPa}$. (Figura 35). 
Tabela 2. Porosidade das amostras produzidas por "Space-Holder".

\begin{tabular}{l|ccc}
\hline Polímero Natural & $\begin{array}{c}\text { Adição de 10\% em } \\
\text { peso }\end{array}$ & $\begin{array}{c}\text { Adição de 20\% em } \\
\text { peso }\end{array}$ & $\begin{array}{c}\text { Adição de 30\% em } \\
\text { peso }\end{array}$ \\
\hline Amido de milho & $15 \%$ & $43 \%$ & - \\
Amido de batata & $20 \%$ & $38 \%$ & - \\
Amido de arroz & $21 \%$ & - & - \\
Albumina & $34 \%$ & $29 \%$ & $31 \%$ \\
Alginato & $31 \%$ & - & - \\
Gelatina & $25 \%$ & - & - \\
\hline
\end{tabular}

A variação na pressão aplicada durante a prensagem uniaxial influencia diretamente a porosidade final da peça. Quanto menor a pressão, mais coerente são os resultados quando comparadas diferentes proporções de albumina adicionadas. Ou seja, quanto menor a concentração de albumina, menos poros se formam na estrutura. $A$ pressão aplicada de $148 \mathrm{MPa}$ proporcionou melhores resultados, e as demais pressões estudadas não permitiram diferenciar os valores na porosidade final das peças. $O$ hidreto de titânio $\left(\mathrm{TiH}_{2}\right)$ tem comportamento mais semelhante à uma cerâmica do que a um metal, portanto, não sofre deformações durante o processo de prensagem. A eliminação do excesso de polímero durante a prensagem pode explicar o comportamento incoerente da porosidade final das amostras que sofreram pressões maiores que $148 \mathrm{MPa}$.

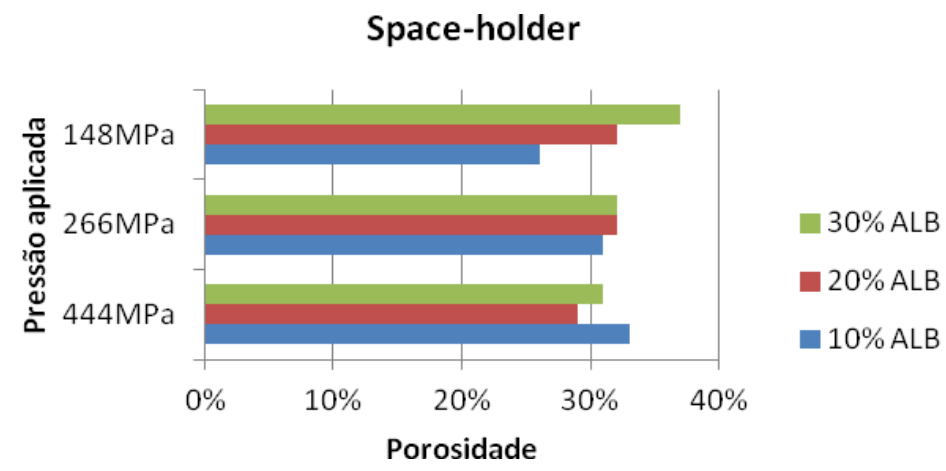

Figura 35. Gráfico relacionando a pressão aplicada (MPa) e porosidade (\%) das amostras com adições de albumina, pela técnica "Space-Holder".

A morfologia dos poros, da amostra com adição de albumina, pode ser observada na Figura 36. Os poros estão bem distribuídos na estrutura e possuem tamanhos homogêneos. 

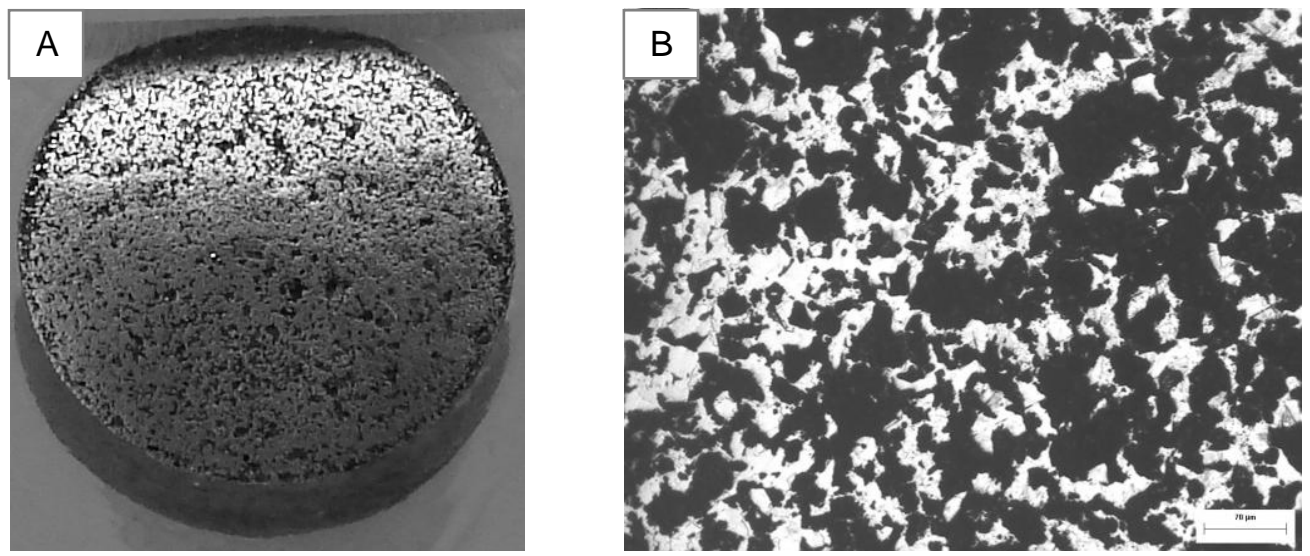

Figura 36. Amostra sinterizada porosa com adição de 30\% de albumina, prensada à 148 MPa: A) imagem macroscópica, diâmetro da amostra 5mm; B) microscopia óptica.

Outra metodologia utilizada foi a técnica da suspensão, na proporção de $8 \%$ e $16 \%$ em peso de polímero natural em relação ao total de sólidos, mais água aquecida na proporção de $1 \mathrm{~mL} / \mathrm{g}$ em relação ao total de polímero. A relação de perda de massa das amostras produzidas por esta técnica não foi clara (Figura 37), talvez porque a absorção de água pelos polímeros é diferente. Isso justificaria uma perda de massa maior que a inicial, como no caso das amostras com $8 \%$ de amido de milho, amido de arroz e amido de batata.

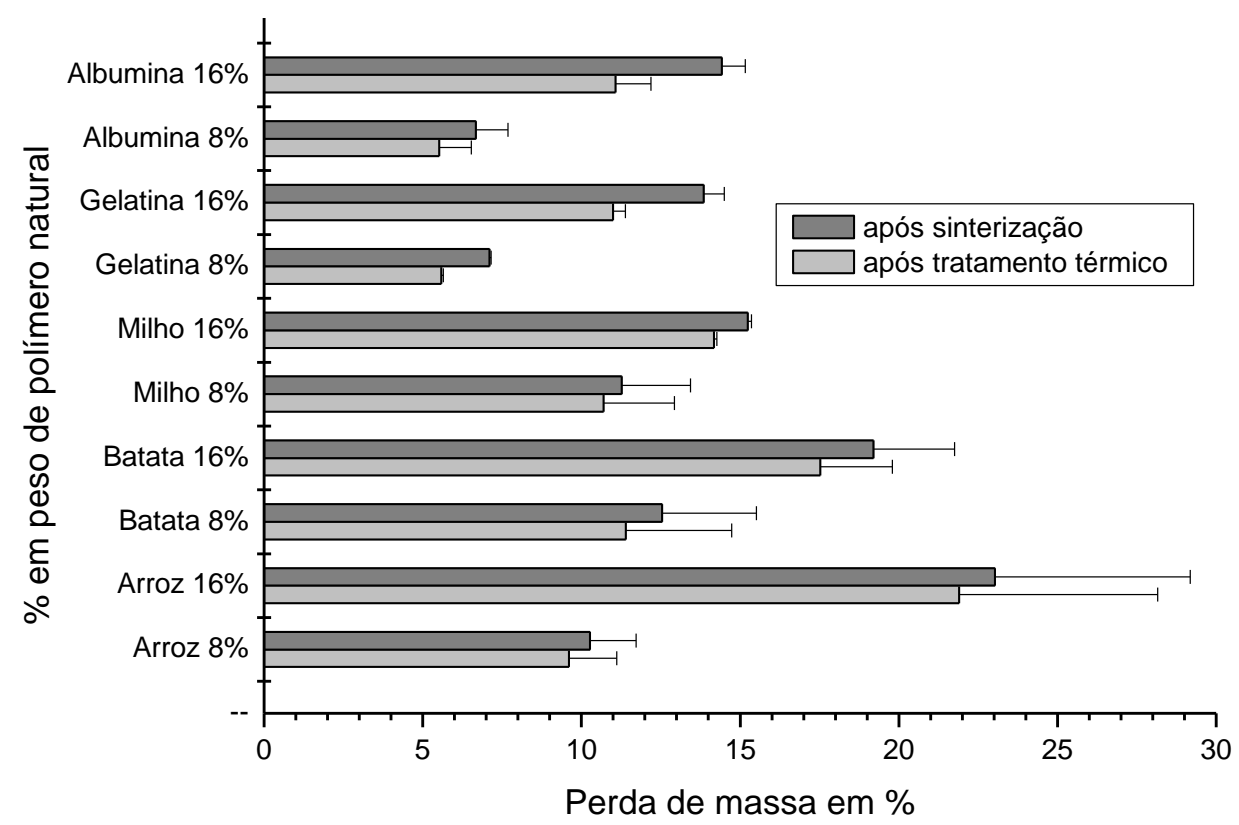

Figura 37. Perda de massa (\%) das amostras obtidas por suspensão após tratamento térmico e sinterização. 
O alginato devido a sua ampla utilização nas áreas médicas foi um dos polímeros utilizados no processamento pela técnica da suspensão. As amostras com 8 e 16\% de alginato não apresentaram resistência ao manuseio em temperatura ambiente, após o período de 12 horas em freezer, por esta razão foram descartados do experimento. A adição de $8 \%$ de albumina possibilitou a obtenção de amostras com o maior valor de porosidade, $71 \%$. Os valores obtidos pelas amostras com albumina no processo de suspensão também não foram coerentes, concentrações mais baixas apresentaram porosidade mais elevada, durante a manipulação da albumina em meio líquido houve a formação de aglomerados que se misturam dificilmente com o pó do titânio, prejudicando o preenchimento do molde. Diferente dos outros polímeros naturais, a gelatina teve uma modificação do processo, durante a fase de remoção de água pré-tratamento térmico. As amostras com gelatina após serem retiradas do molde, foram colocadas em dessecador para remoção da umidade e não foram colocadas em estufa. Por esta modificação na técnica foi observada considerável retração volumétrica da peça, porém os valores da porosidade foram elevados (56\%) (Figura 38).

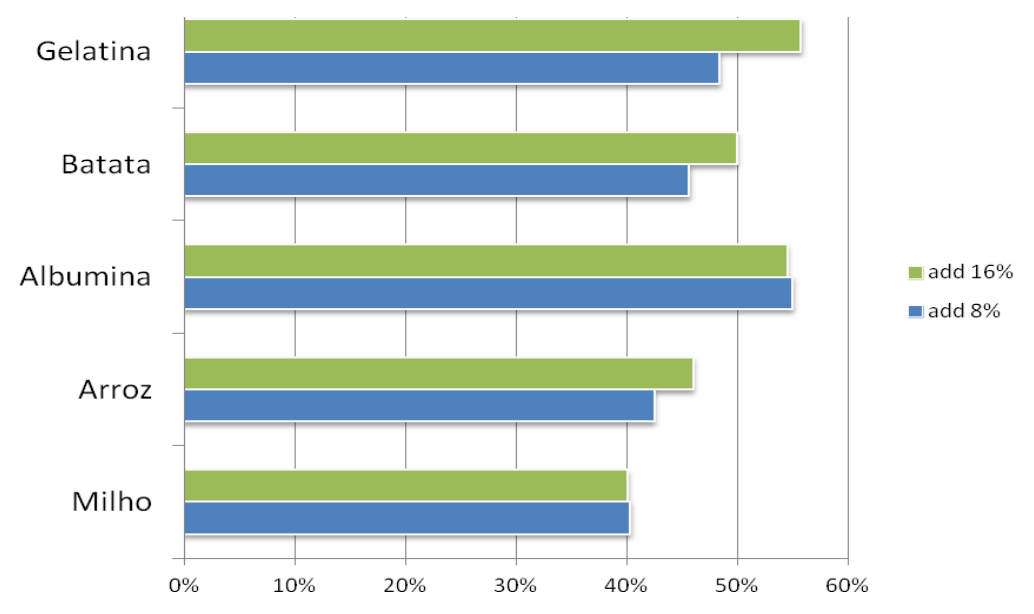

Figura 38. Porosidade (\%) das amostras acrescidas de 8 e $16 \%$ de polímeros naturais pela técnica da suspensão.

Por análise macroscópica e por microscopia óptica foram observadas as amostras com relação à porosidade. Visualmente, foram observados poros mais homogêneos nas amostras com adição de amido de batata e de milho, embora comparativamente as amostras obtidas com amido de batata, tenham apresentado poros com maior diâmetro. Observaram-se poros de tamanho heterogêneo para amostras com adição de amido e de gelatina, com macroporos interligados. A escolha destes polímeros levou em consideração não apenas pelo porcentual de porosidade, mas também a distribuição, 
tamanho e formato dos poros. Desta forma, pela técnica de suspensão os polímeros naturais para serem utilizados como aditivos adicionados em $16 \%$ em peso, foram: amido de arroz, amido de batata, amido de milho e gelatina.
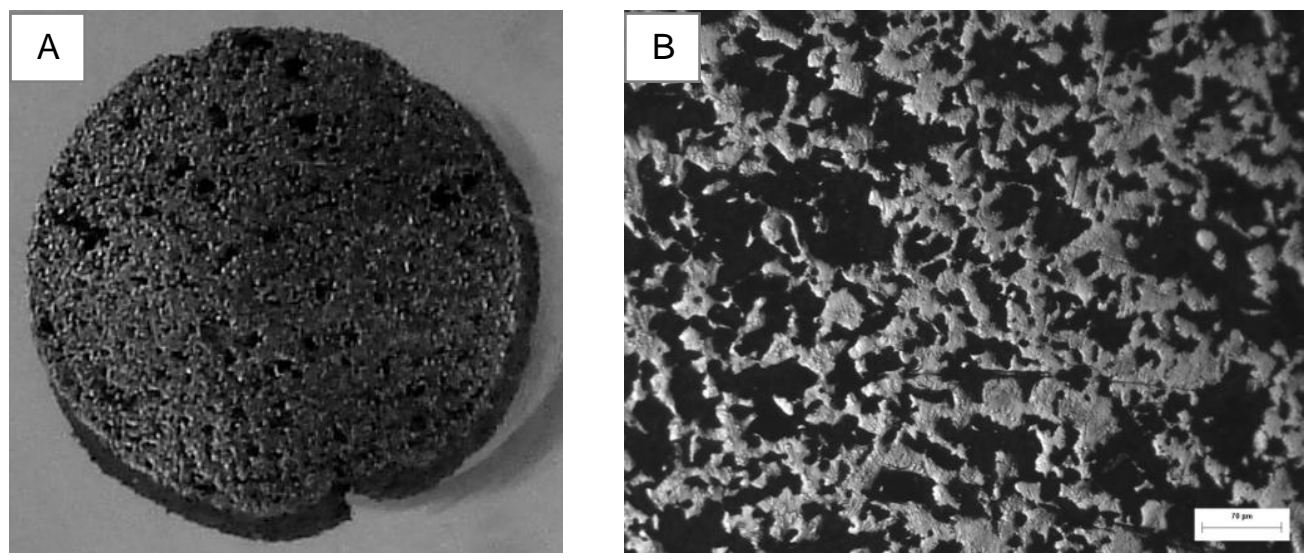

Figura 39. Amostra sinterizada com adição de amido de arroz 16\% em suspensão: A) imagem macroscópica, diâmetro da amostra $\sim 5 \mathrm{~mm}$; B) microscopia óptica.
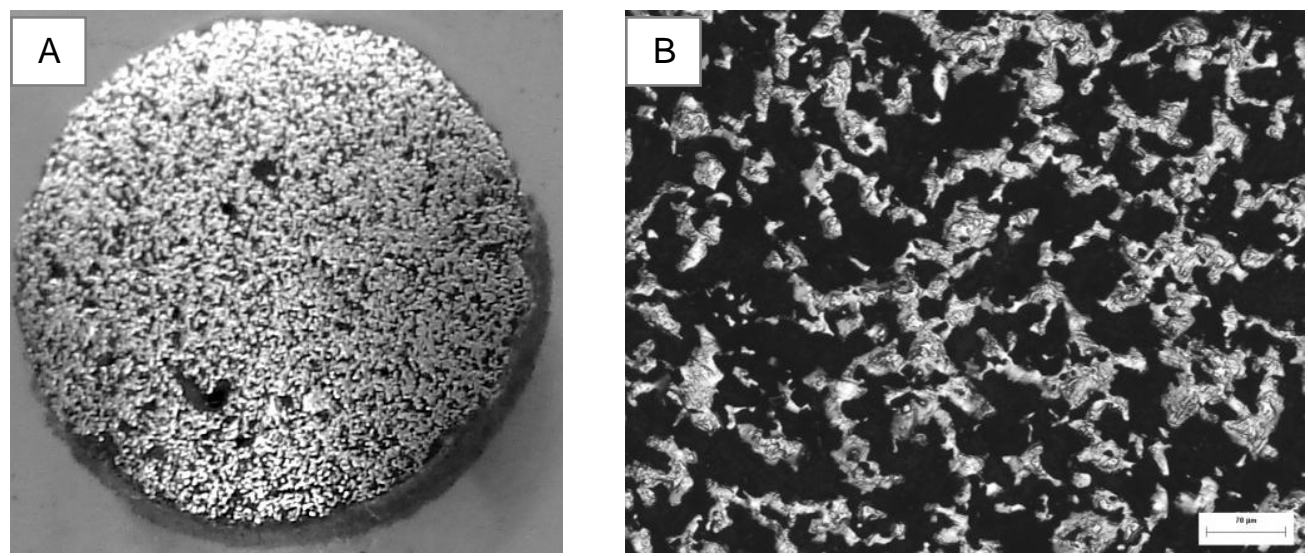

Figura 40. Amostra sinterizada com adição de amido de batata $16 \%$ em suspensão: A) imagem macroscópica, diâmetro da amostra 5mm; B) microscopia óptica.
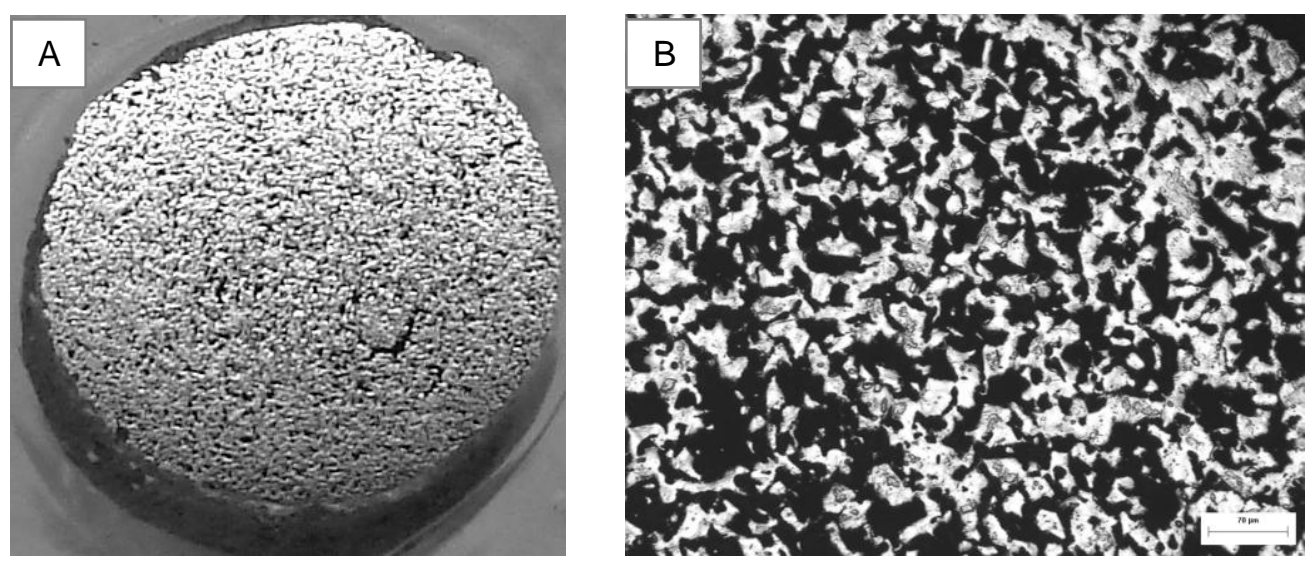

Figura 41. Amostra sinterizada com adição de amido de milho 16\% em suspensão: A) imagem macroscópica, diâmetro da amostra $5 \mathrm{~mm}$; B) microscopia óptica. 

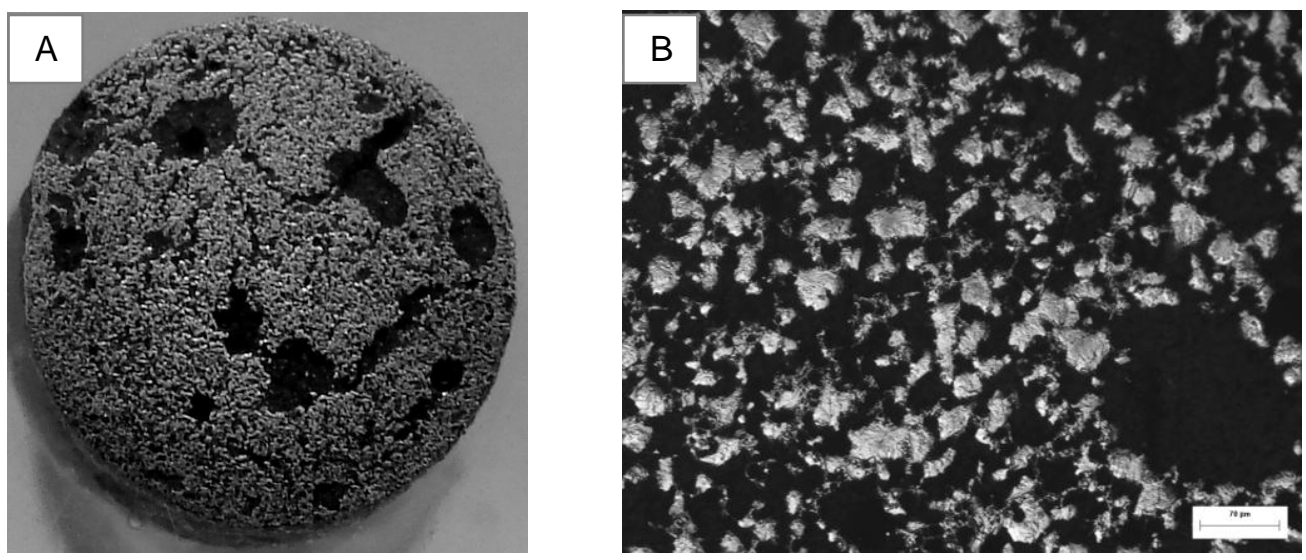

Figura 42. Amostra sinterizada com adição de gelatina 16\% em suspensão: A) imagem macroscópica, diâmetro da amostra $\sim 5 \mathrm{~mm}$; B) microscopia óptica.

\subsection{Caracterização dos materiais porosos}

A partir da seleção das técnicas de processamento (suspensão e "space-holder") e dos polímeros naturais (amido de arroz, amido de batata, amido de milho, gelatina e albumina), foram obtidas amostras de Ticp e liga Ti-13Nb-13Zr (Tabela 3). Amostras densas foram utilizadas para comparar as porosidades obtidas.

Tabela 3. Técnicas de processamento e polímeros naturais utilizados.

\begin{tabular}{c|l}
\hline \multicolumn{1}{c|}{ Técnica } & Polímero Natural \\
\hline \multirow{2}{*}{ "Space-Holder" } & Albumina \\
\hline \multirow{4}{*}{ Suspensão } & Amido de Arroz \\
\cline { 2 - 2 } & Amido de Batata \\
\cline { 2 - 2 } & Amido de Milho \\
\cline { 2 - 2 } & Gelatina \\
\hline
\end{tabular}

Foram calculados os valores de porosidade: relativa, aparente e por análise de imagem das amostras sinterizadas dos grupos estudados ("space-holder", suspensão) . Alguns grupos apresentam diferenças entre as análises, principalmente as amostras de Ticp: gelatina, amido de milho e amido de arroz. Essa diferença pode ser identificada pela discrepância nos resultados obtidos por análise de imagem (Figura 43). A justificativa é que mesmo se fazendo a análise a partir de várias imagens, não foi obtida a representavidade da amostra. Por esta razão, a análise de imagem não deve ser utilizada como único parâmetro para porosidade e/ou densidade. Outras aplicações podem ser 
bem exploradas por esta análise, como por exemplo, caracterização de poros quanto a morfologia, dimensões, distribuição e microestrutura.

Os valores de porosidade relativa e aparente nas amostras densas das duas composições apresentam variação. A porosidade relativa calculada a partir das medidas de densidade hidrostática tem valores mais confiáveis para mensurar corpos densos, enquanto que para a determinação de porosidade aparente a amostra já é considerada porosa. Quanto mais porosa a amostra, menor a discrepância entre os resultados (Figura 43).
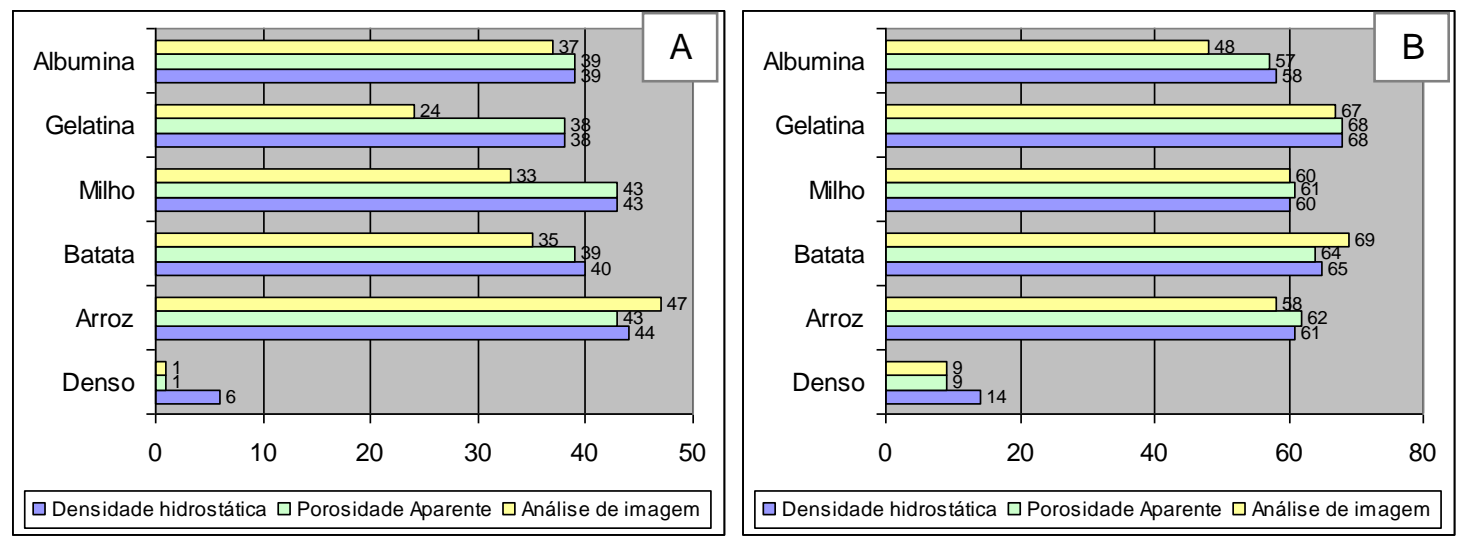

Figura 43. Comparação entre as técnicas para determinação da porosidade para amostras de Ticp (A) e Liga (B).

Apesar de ter-se seguido a mesma metodologia de obtenção para a Liga Ti-13Nb13Zr e para o Ticp, há uma diferença significativa na porosidade entre os dois grupos, $\sim 60 \%$ e $\sim 40 \%$ de porosidade (Figura 44 ), respectivamente. A matéria prima utilizada para o grupo de Ticp é hidreto, e da Liga Ti-13Nb-13Zr são pós metálicos.

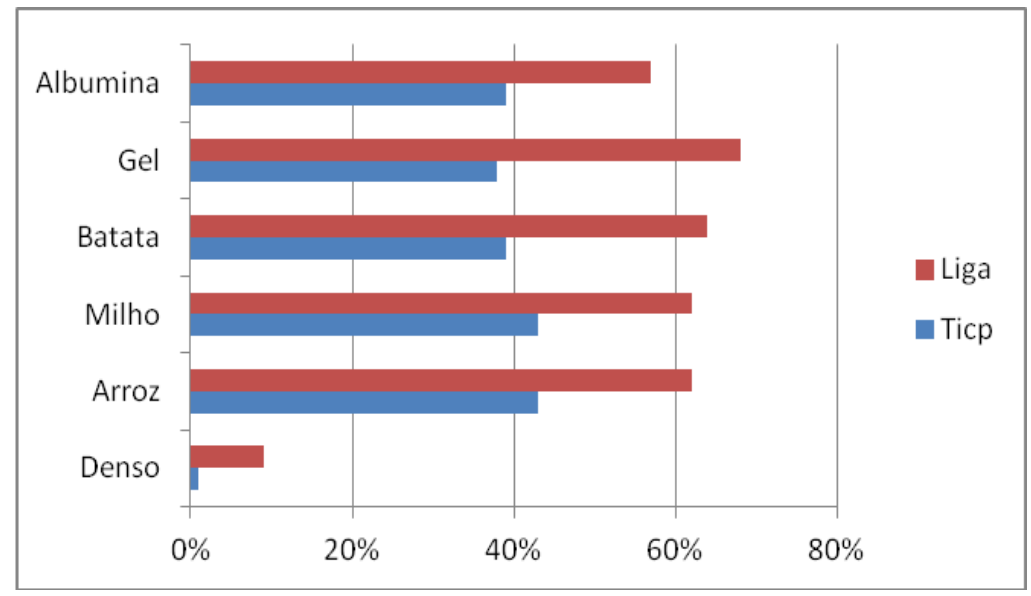

Figura 44. Valores porcentuais de porosidade aparente. 
Durante o processo de sinterização, gases que não apresentam solubilidade no sólido podem ser aprisionados nos contornos dos grãos, formando poros fechados de formato arredondado. Esses poros fechados presentes na estrutura dificultam a proximidade do valor da densidade real em relação à densidade teórica ${ }^{55}$.

A caracterização por picnometria de hélio foi utilizada para determinar a densidade real do corpo de cada amostra (Tabela 4). Para as amostras de Ticp, com densidade teórica de $4,51 \mathrm{~g} / \mathrm{cm}^{3}$, as amostras densas apresentam maior porcentagem de poros fechados (3,3\%) em relação aos porosos de mesma composição (1,5 3\%). Isso pode ser explicado pela maior área de contato dos grãos nas amostras sem aditivos poliméricos, fazendo com que haja a formação de poros fechados. Para as amostras da Liga Ti-13Nb-13Zr com densidade teórica $5,01 \mathrm{~g} / \mathrm{cm}^{3}$, algumas amostras apresentam valores de densidade maiores do que a densidade teórica da Liga Ti-13Nb-13Zr. Existe a influência das densidades do nióbio $\left(8,5 \mathrm{~g} / \mathrm{cm}^{3}\right)$ e do zircônio $\left(6,5 \mathrm{~g} / \mathrm{cm}^{3}\right)$ que não reagidos elevam os valores de densidade. O maior valor de porosidade fechada foi o da amostra densa da Liga, 3,8\% (Tabela 4).

Tabela 4. Densidade obtida por picnometria de hélio das amostras densas e porosas.

\begin{tabular}{lccc|lccc}
\hline $\begin{array}{c}\text { Ticp } \\
\text { Amostras }\end{array}$ & $\begin{array}{c}\text { Densidade } \\
\left(\mathrm{g} / \mathrm{cm}^{3}\right)\end{array}$ & $\begin{array}{c}\text { Desvio } \\
\text { padrão }\end{array}$ & $\begin{array}{c}\text { Porosidade } \\
\text { fechada } \\
(\%)\end{array}$ & $\begin{array}{c}\text { Liga } \\
\text { Amostras }\end{array}$ & $\begin{array}{c}\text { Densidade } \\
\left(\mathrm{g} / \mathrm{cm}^{3}\right)\end{array}$ & $\begin{array}{c}\text { Desvio } \\
\text { padrão }\end{array}$ & $\begin{array}{c}\text { Porosidade } \\
\text { fechada } \\
(\%)\end{array}$ \\
\hline Denso & 4,36 & 0,01 & 3,3 & Denso & 4,82 & 0,01 & 3,8 \\
Arroz & 4,44 & 0,01 & 1,5 & Arroz & 5,1 & 0,01 & $-1,8$ \\
Batata & 4,4 & 0,01 & 2,4 & Batata & 4,99 & 0,01 & 0,4 \\
Milho & 4,38 & 0,01 & 2,9 & Milho & 4,99 & 0,01 & 0,4 \\
Gelatina & 4,42 & 0,01 & 2,0 & Gelatina & 5,05 & 0,01 & $-0,8$ \\
Albumina & 4,42 & 0,01 & 2,0 & Albumina & 4,94 & 0,01 & 1,4 \\
\hline
\end{tabular}

Os parâmetros de rugosidade foram analisados, constatando-se que o grupo da Liga Ti-13Nb-13Zr é mais rugoso do que o grupo de Ticp. As amostras densas e usinadas apresentam baixos valores de rugosidade $(\mathrm{Ra}<1 \mu \mathrm{m})$, similares à literatura ${ }^{84}$, viabilizando-as como um bom grupo controle. Entre as maiores distâncias dos picos e vales, representadas pelo parâmetro Ry, observa-se uma semelhança entre os grupos porosos de mesma composição, Ticp e Liga, destacando os maiores valores para as amostras porosas de Liga Ti-13Nb-13Zr (Figura 45). 


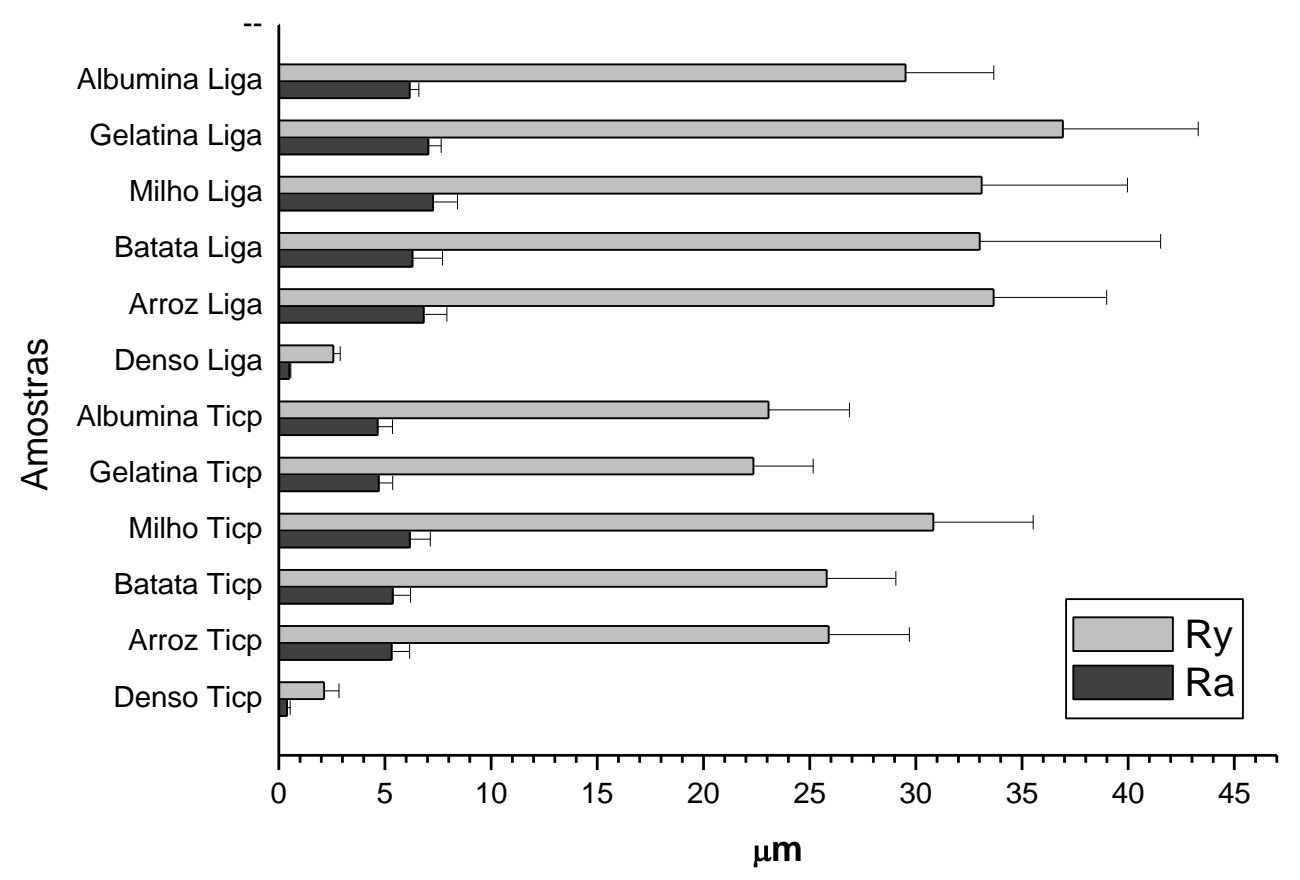

Figura 45. Gráfico de rugosidade.

A seguir serão discutidas as técnicas de processamento de porosos, assim como a diferença na porosidade entre as amostras de composição Ticp e Liga.

\subsubsection{Técnica "Space-Holder"}

Amostras produzidas pela técnica do "space-holder" com a mesma quantidade de albumina apresentam uma diferença significativa. A porosidade calculada pela fórmula de porosidade aparente mostra $\sim 40 \%$ de porosidade para as amostras de Ticp e $\sim 60 \%$ para a Liga (Figura 44). Assim como nas amostras densas, essa diferença pode ser caracterizada pelo discrepante tamanho médio de partícula dos pós utilizados.

Os materiais obtidos pela técnica do "space-holder" com adição de 30\% de albumina em peso proporcionaram a formação de poros com o tamanho médio variando entre 5,5 $\mu \mathrm{m}$ a $110 \mu \mathrm{m}$ de diâmetro para as amostras de Ticp (Figura 54), e 3,5 $\mu \mathrm{m}$ a 100 $\mu \mathrm{m}$ para as amostras da Liga Ti-13Nb-13Zr (Figura 60); lembrando que o tamanho médio de partícula da albumina é de $\sim 45 \mu \mathrm{m}$. Os poros não apresentam formato próximo ao esférico sendo bastante irregulares homogeneamente distribuídos na estrutura (Figura 46, Figura 47). 

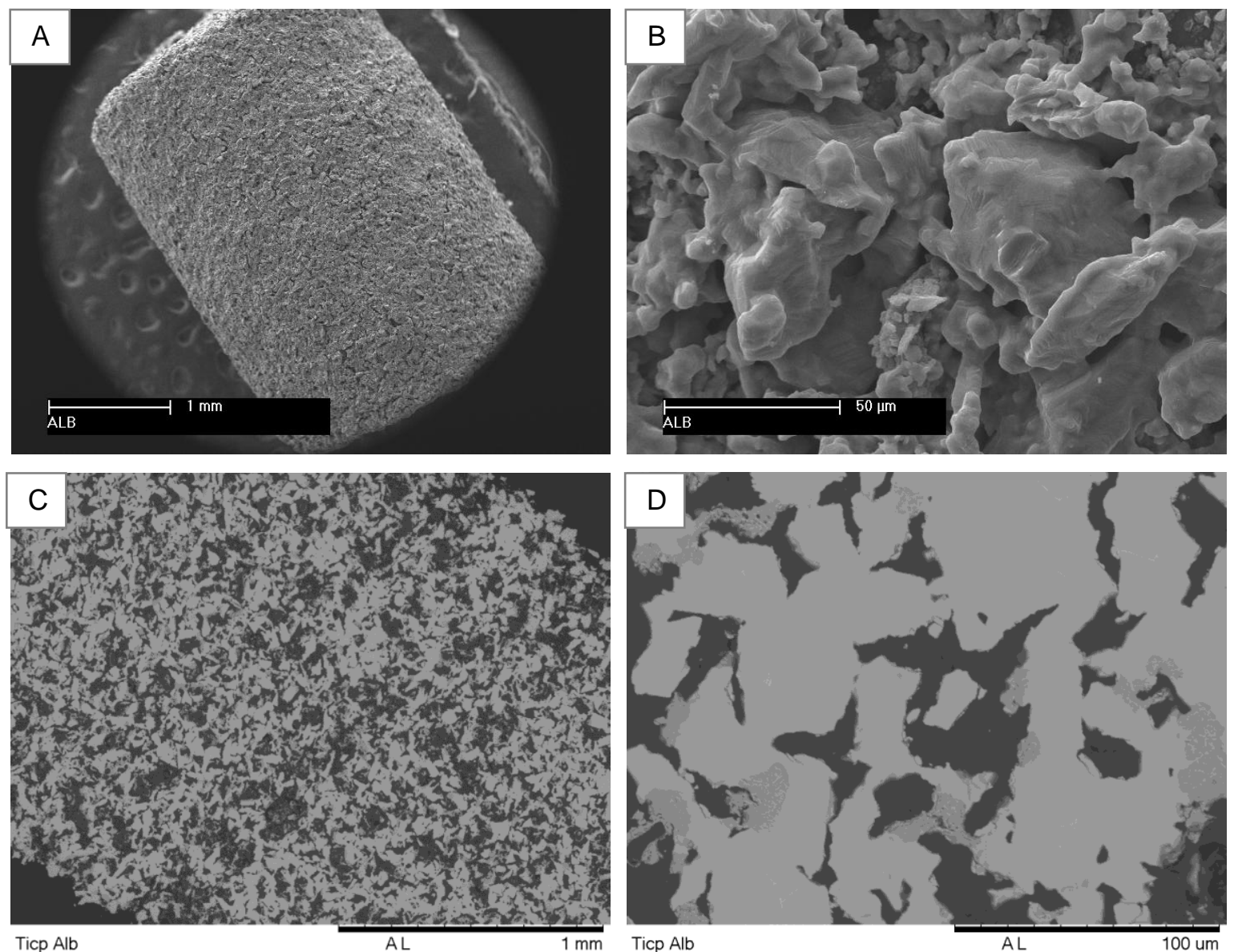

Figura 46. MEV da amostra de Ticp poroso com adição de $30 \%$ de albumina: A) visualização da rugosidade da amostra, B), topografia após sinterização. MEV da microestrutura da secção transversal e polida:C) poros homogeneamente distribuídos na microestrutura, D) irregularidade no formato dos poros. 

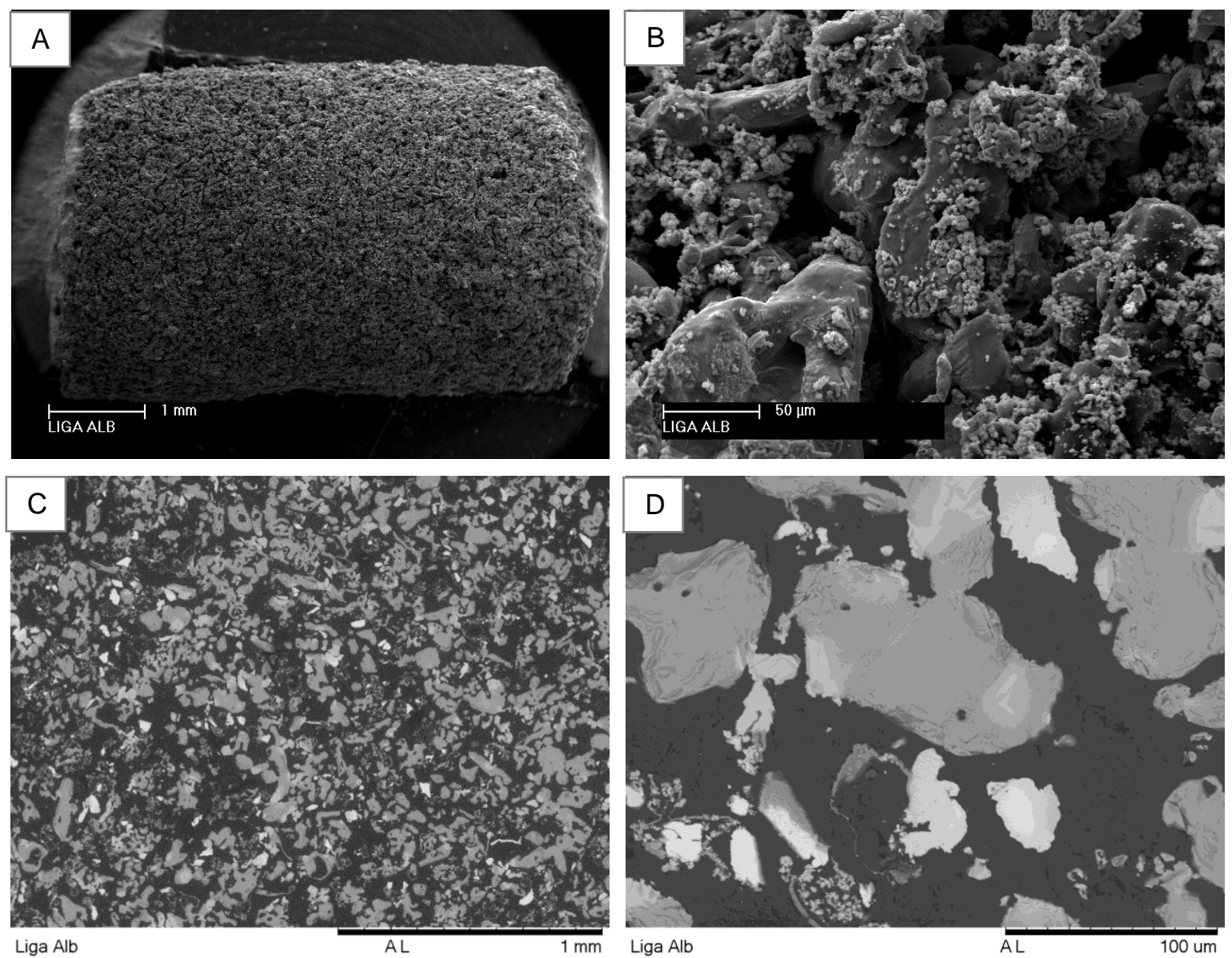

Figura 47. MEV da amostra da Liga porosa com adição de $30 \%$ de albumina: A) visualização da rugosidade da amostra, B) topografia após sinterização. MEV da microestrutura da secção transversal e polida:C) poros homogeneamente distribuídos na microestrutura, D) irregularidade no formato dos poros.

A caracterização da superfície da amostra foi analisada por microscopia eletrônica de varredura (MEV), e tanto as amostras de Ticp quanto as de Liga, as superfícies mostram-se bastante rugosas, com elevada área de superfície específica. Os resultados de rugosidade (Figura 45) revelam que as amostras da Liga Ti-13Nb-13Zr com albumina, produzidas pela técnica do "space-holder", são mais rugosas que as amostras de Ticp. É possível observar a formação de pescoços decorrentes da sinterização, esperado no processo (Figura 46). Observa-se nas amostras da Liga Ti-13Nb-13Zr a microestrutura homogênea com a presença de fases a e $\beta$ (Figura 47), como comprovado pela análise de DRX. A fase TiO foi também identificada nas amostras de Ticp e Liga Ti-13Nb-13Zr (Figura 48). 

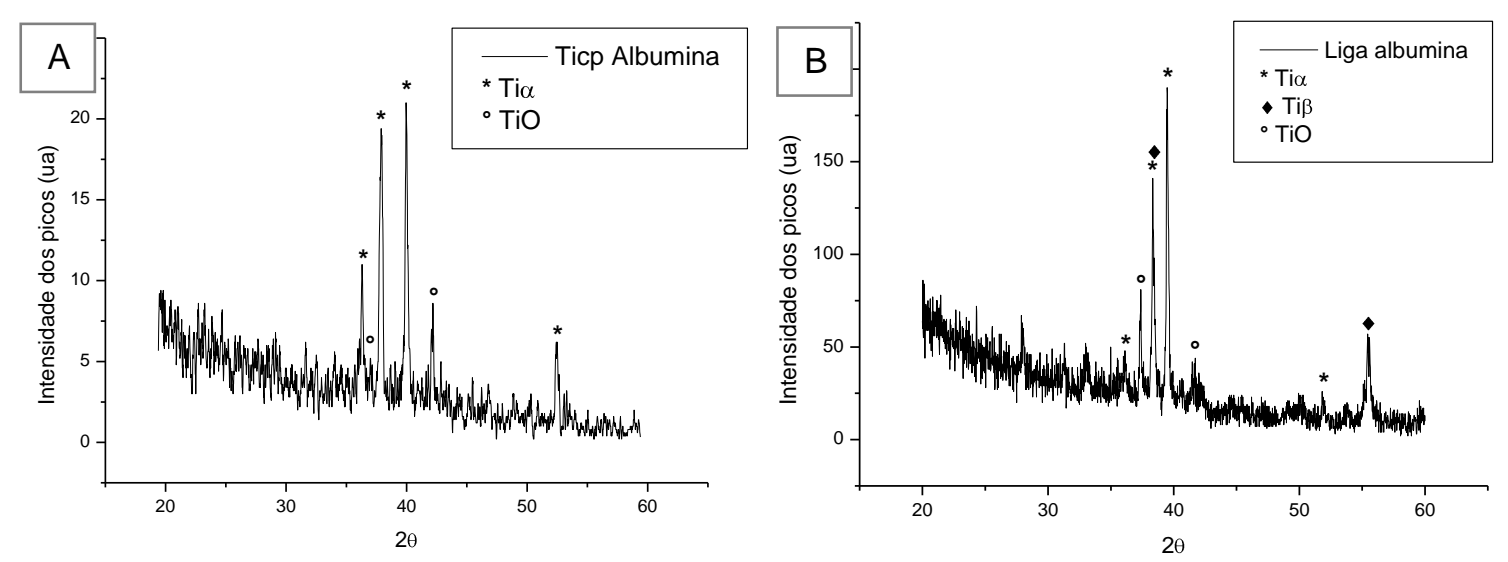

Figura 48. DRX das amostras porosas com adição de $30 \%$ de albumina: A) Ticp, presença da fase $\alpha$ e fase TiO; B) Liga, presenças das fases $\alpha$ e $\beta$, e fase TiO.

A metodologia de "space-holder" com adição de albumina provoca a formação de um óxido, que pode estar relacionado com a maior área de superfície obtida. Mansourighasri et al. ${ }^{85}$, estudaram processamento por "space-holder" utilizando amido de mandioca ( $50 \%$ em volume) e pó de titânio metálico, as amostras obtidas com tratamento térmico $\left(450^{\circ} \mathrm{C} / 2 \mathrm{~h}\right)$ e sinterização $\left(1300^{\circ} \mathrm{C} / 3 \mathrm{~h}\right)$ ocorreram em uma única etapa em forno a vácuo, apresentam porosidade entre 64 e 79\%. Por análise de DRX, não houve solubilização do "space-holder" utilizado, e não foi encontrado como contaminante no final do processo.

A técnica de "space-holder" é bastante discutida na literatura, porém existem inúmeras variantes que dificultam a comparação entre os resultados. $O$ tipo de material utilizado como "space-holder" é um fator de suma importância no processamento. Alguns autores utilizam sais de $\mathrm{NaCl}$ ou $\mathrm{NaF}$, que necessitam ser removidos por dissolução, podendo levar semanas para que esta ocorra ${ }^{86,87}$. O processo térmico por utilizar agentes orgânicos pode ser bem mais rápido ${ }^{85}$. Outro aspecto associado ao tipo de material é a toxicidade, o $\mathrm{NaF}$ apresenta toxicidade quando inalado ou ingerido, e em elevada concentração pode afetar o coração e sistema circulatório ${ }^{85}$. Por esta razão, é importante utilizar materiais que sejam ambientalmente amigáveis, como é o caso dos amidos ${ }^{85}$.

A albumina foi o material escolhido para aplicar a técnica de "space-holder", além de preencher os requisitos descritos, espera-se agregar suas características biológicas no processamento. A albumina é uma das proteínas mais abundante no sangue, sendo também uma das proteínas a ser adsorvida na superfície do implante quando em contato com o organismo, durante o processo de reconhecimento molecular entre o tecido e o biomaterial. Uma caracterização dos poros poderia permitir uma melhor resposta da 
adsorção de proteína, não só pelas interações químicas como também pelo reconhecimento morfológico das ligações com a proteína. Apesar de inédito o uso de albumina como "space-holder", mais estudos são necessários para comprovar esta teoria, mas as boas respostas desses materiais em sistema biológico os tornam promissores.

Outros fatores durante o processamento podem ser determinantes na produção de poros na estrutura. Trabalhos utilizando a técnica do "space-holder" variam: tamanho médio de partícula (tanto do metal em pó, quanto do "space-holder"), proporção metal/"space-holder" e pressão durante a compactação. Todos esses fatores podem influenciar no tamanho de poro final, assim como a porcentagem de porosidade. Os dados encontrados na literatura que corroboram para essa afirmação estão compilados na Tabela 5.

Tabela 5. Variações no processamento por metalurgia do pó e space-holder, resultando em diferentes tamanho de poros e porosidade.

\begin{tabular}{|c|c|c|c|c|c|}
\hline Autor & $\begin{array}{c}\text { Particulado, } \\
\text { granulometria e } \\
\text { formato da } \\
\text { partícula }\end{array}$ & $\begin{array}{c}\text { Space-holder, } \\
\text { granulometria e } \\
\text { porcentagem } \\
\text { wt } \%\end{array}$ & $\begin{array}{c}\text { Prensage } \\
\text { m à frio }\end{array}$ & $\begin{array}{l}\text { Tamanho de } \\
\text { poro }\end{array}$ & $\begin{array}{c}\text { Porosi- } \\
\text { dade }\end{array}$ \\
\hline Wen, et al ${ }^{5 /}$ & $\begin{array}{l}\text { Ticp } \\
45 \mu \mathrm{m}\end{array}$ & $\begin{array}{l}\text { Carbonato de } \\
\text { amônio } \\
\text { hidrogenado }\end{array}$ & $100 \mathrm{MPa}$ & $200 \sim 500 \mu \mathrm{m}$ & $78 \%$ \\
\hline Esen et al ${ }^{88}$ & $\begin{array}{l}\text { Ticp } \\
74 \mu \mathrm{m} \\
\text { esférico }\end{array}$ & $\begin{array}{l}\text { Magnésio } \\
425-600 \mu \mathrm{m} \\
40 \sim 70 \%\end{array}$ & $500 \mathrm{MPa}$ & $\begin{array}{l}\text { Macro: } \\
525 \sim 1500 \mu \mathrm{m} \\
\text { Micro: } 30 \sim 220 \\
\mu \mathrm{m}\end{array}$ & $40 \sim 70 \%$ \\
\hline$\underset{89}{\text { Weniuan et al }}$ & $\begin{array}{l}\text { Ticp } \\
44-74 \mu \mathrm{m} \\
\text { irregular } \\
\end{array}$ & $\begin{array}{l}\text { Carbamida } \\
200-600 \mu \mathrm{m}\end{array}$ & - & $300 \sim 500 \mu \mathrm{m}$ & $55 \sim 75 \%$ \\
\hline $\begin{array}{l}\text { Vasconcellos } \\
\text { et al }{ }^{62}\end{array}$ & $\begin{array}{l}\mathrm{TiH} 2 \\
8 \mu \mathrm{m} \\
\text { irregular }\end{array}$ & $\begin{array}{l}\text { Ureia } \\
200 \mu \mathrm{m} \\
20 \%\end{array}$ & $200 \mathrm{MPa}$ & $360 \mu \mathrm{m}$ & $36 \%$ \\
\hline Sharma et al & $\begin{array}{l}\text { Ticp } \\
45 \mu \mathrm{m} \\
\text { irregular }\end{array}$ & $\begin{array}{l}\text { Ureia } \\
1000 \mu \mathrm{m} \\
16,7 \%\end{array}$ & $50 \mathrm{MPa}$ & $\begin{array}{l}\text { Macro: } 150 \mu \mathrm{m} \\
\text { Micro: } 1 \sim 10 \\
\mu \mathrm{m}\end{array}$ & $55 \%$ \\
\hline Xiang et al ${ }^{90}$ & $\begin{array}{l}\mathrm{TiH} 2 \\
45 \mu \mathrm{m} \\
\text { irregular }\end{array}$ & $\begin{array}{l}\text { Carbonato de } \\
\text { Amônio } \\
841 \mu \mathrm{m}\end{array}$ & $200 \mathrm{MPa}$ & $5 \sim 300 \mu \mathrm{m}$ & $56 \%$ \\
\hline $\begin{array}{l}\text { Mansourighas } \\
\text { ri et al. }{ }^{85}\end{array}$ & $\begin{array}{l}\text { Ticp } \\
20 \mu \mathrm{m} \\
\text { esférico }\end{array}$ & $\begin{array}{l}\text { Tapioca } \\
100-400 \mu \mathrm{m} \\
50 \%\end{array}$ & $100 \mathrm{MPa}$ & $100 \sim 300 \mu \mathrm{m}$ & $64 \sim 79 \%$ \\
\hline
\end{tabular}

Apesar de existirem inúmeros trabalhos relacionados à técnica de "Space-holder" as variáveis de processamento impossibilitam a correlação entre os resultados de tamanho de poro e porosidade. Neste trabalho, procurou-se padronizar alguns parâmetros para efeito comparativo. 


\subsubsection{Técnica da Suspensão}

O ineditismo da técnica da suspensão desenvolvida neste trabalho é em relação à simplificação da técnica de "freeze-drying", tornando o processo mais econômico, sem a necessidade de equipamentos específicos. $O$ congelamento instantâneo da suspensão em nitrogênio líquido permite manter a forma da amostra moldada, a remoção da água da suspensão ocorre lentamente por sublimação, em freezer convencional. A colocação das amostras em estufa é necessária para remoção da água residual, precedendo a etapa de tratamento térmico. Os polímeros naturais utilizados neste estudo, permitiram que as amostras, antes e após tratamento térmico, tivessem resistência à manipulação, evitando a utilização de ligantes. É inovador também a utilização dos amidos de milho, arroz e batata para a produção de metais com estrutura porosa pela técnica da suspensão.

As amostras do grupo poroso de Ticp apresentam apenas a fase a na estrutura, como esperado (Figura 49). Os parâmetros de sinterização preconizados neste estudo foram bem eficientes, pois houve a formação de pescoços entre as partículas e ocorreu o arredondamento no formato das mesmas, como mostram as imagens das superfícies, obtidas em MEV (Figura 50, Figura 51, Figura 52, Figura 53).

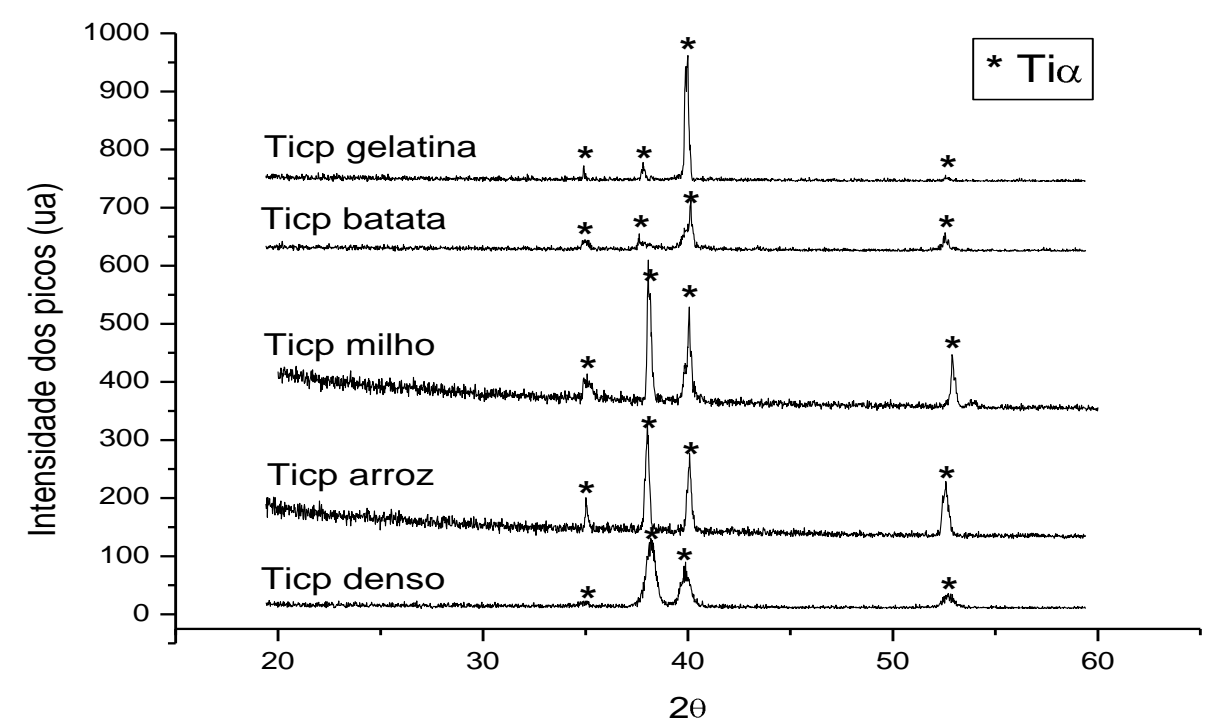

Figura 49. DRX das amostras do grupo poroso de Ticp com adições de: gelatina, amido de batata, amido de milho, amido de arroz e o controle denso. Presença apenas da fase a.

A distribuição e tamanho de poro foram avaliados macroscopicamente (Figura 50C, Figura 51C, Figura 52C, Figura 53C). Nas amostras com adição de amido de milho 
foram obtidos poros homogêneos na estrutura, já com adição de amido de batata proporcionou poros um pouco menores, homogêneos e bem distribuídos, diferenciando apenas no tamanho. $\mathrm{O}$ amido de arroz apesar da baixa granulometria conferiu às amostras tamanho variado de poros com macroporos próximos ao formato esférico e microporos irregulares, bem distribuídos na estrutura. A gelatina, com o maior valor de tamanho médio de partícula, proporcionou a formação de macroporos interligados, e microporos.
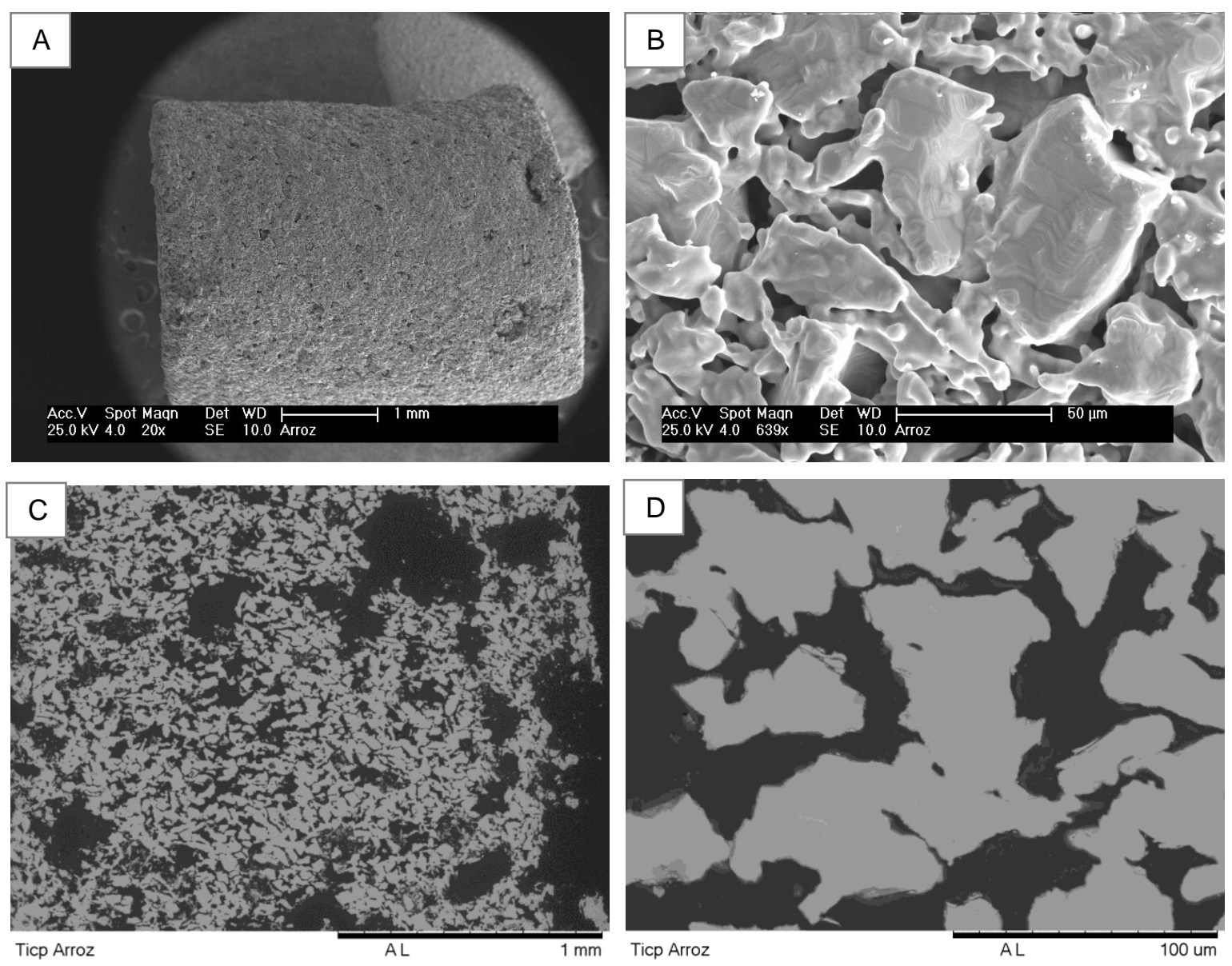

Figura 50. MEV da superfície da amostra de Ticp poroso com adição de $16 \%$ de amido de arroz. A) visualização da rugosidade da amostra, B) topografia após sinterização. MEV da microestrutura da secção transversal e polida: C) poros heterogêneos distribuídos na microestrutura, D) irregularidade dos microporos. 

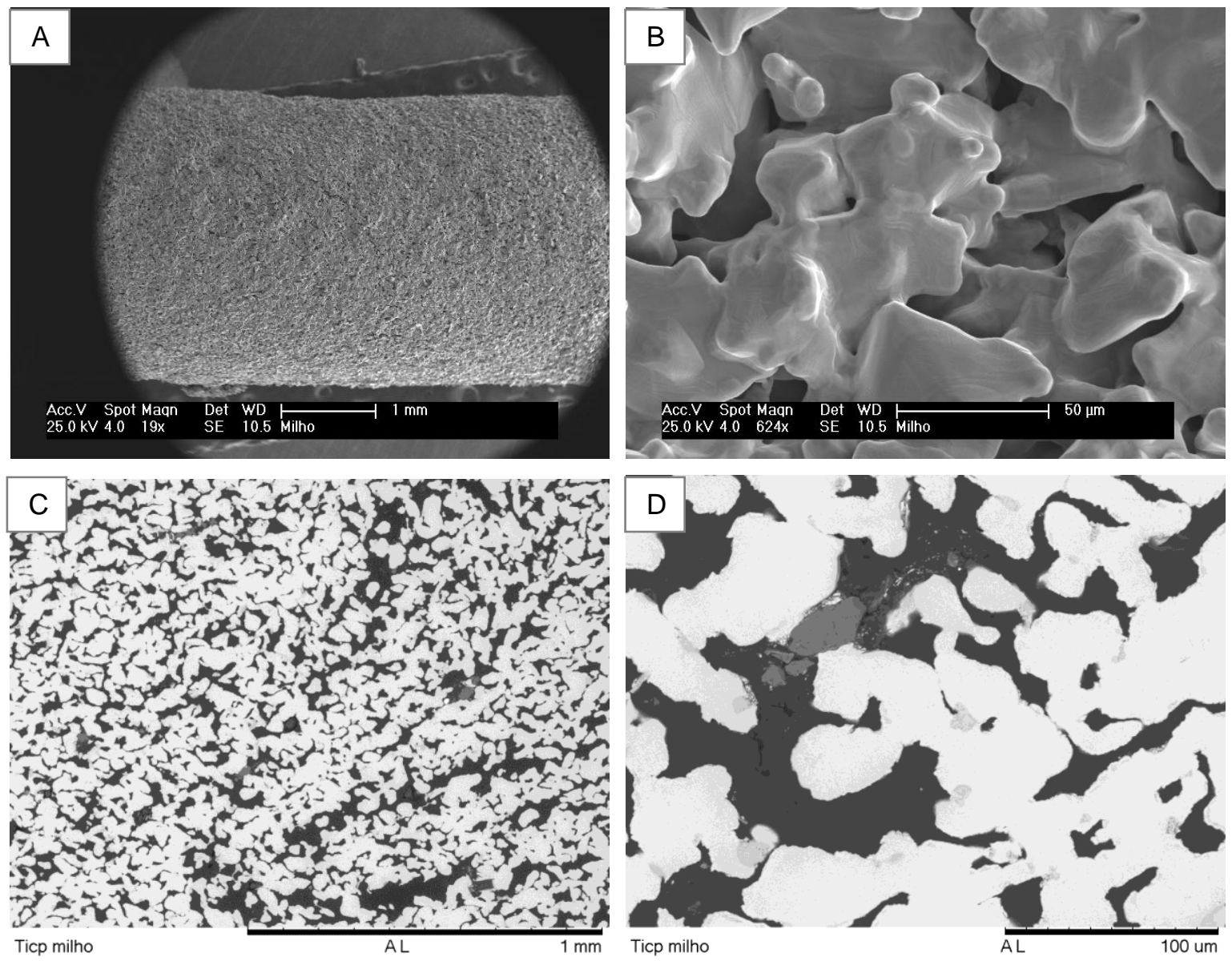

Figura 51. MEV da superfície da amostra de Ticp poroso com adição de $16 \%$ de amido de milho. A) visualização da rugosidade da amostra, B) topografia após sinterização. MEV da microestrutura da secção transversal e polida: C) poros homogêneos distribuídos na microestrutura, D) irregularidade dos poros. 

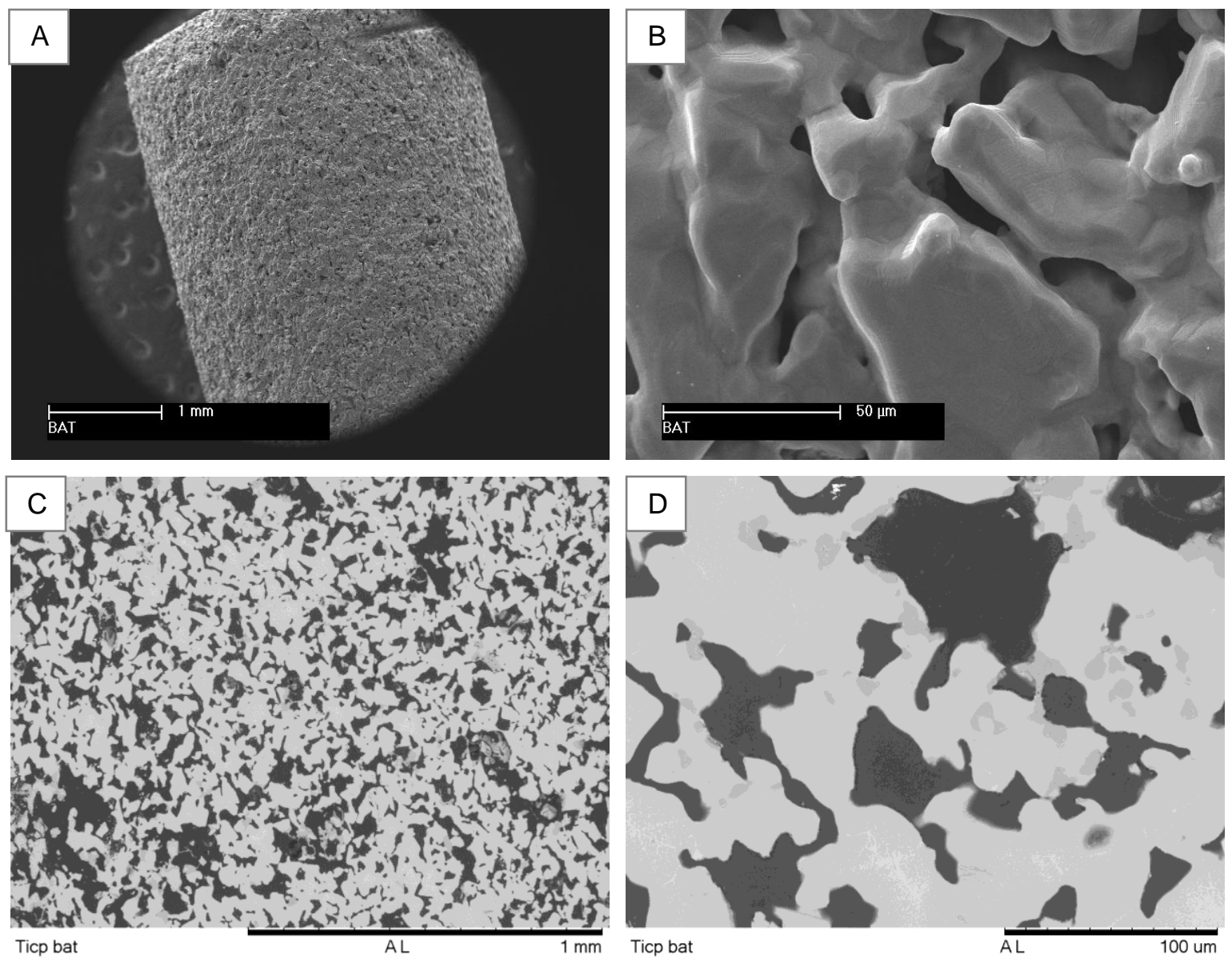

Figura 52. MEV da superfície da amostra de Ticp poroso com adição de $16 \%$ de amido de batata. A) visualização da rugosidade da amostra, B) topografia após sinterização. MEV da microestrutura da secção transversal e polida: C) poros distribuídos na microestrutura, D) irregularidade dos poros. 

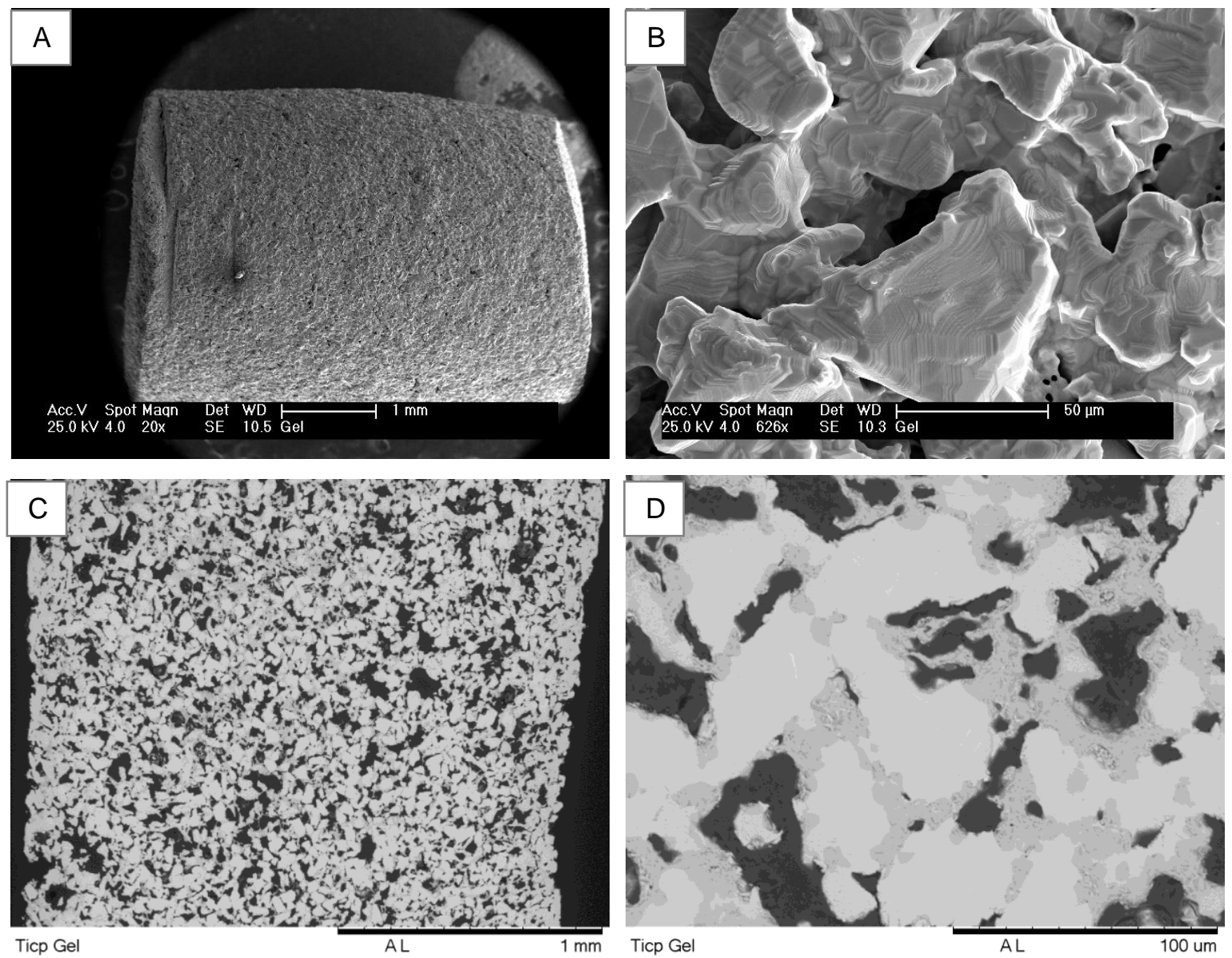

Figura 53. MEV da superfície da amostra de Ticp poroso com adição de $16 \%$ de gelatina. A) visualização da rugosidade da amostra, B) topografia após sinterização. MEV da microestrutura da secção transversal e polida: C) poros distribuídos na microestrutura, D) irregularidade dos poros. 
As amostras de Ticp com adição de amido de arroz apresentam o maior valor de desvio em relação ao valor médio de diâmetro de poros (Figura 54), isso ocorre porque o valor máximo medido foi de $220 \mu \mathrm{m}$ e o mínimo 4,3 $\mu \mathrm{m}$. As amostras contendo amido de milho, e amido de batata apresentam poros com diâmetros mais homogêneos, porém as amostras com amido de milho apresentam poros maiores $(180 \mu \mathrm{m})$ que as amostras com amido de batata $(130 \mu \mathrm{m})$. As amostras com gelatina apresentam os menores valores de diâmetro máximo $(77 \mu \mathrm{m})$.

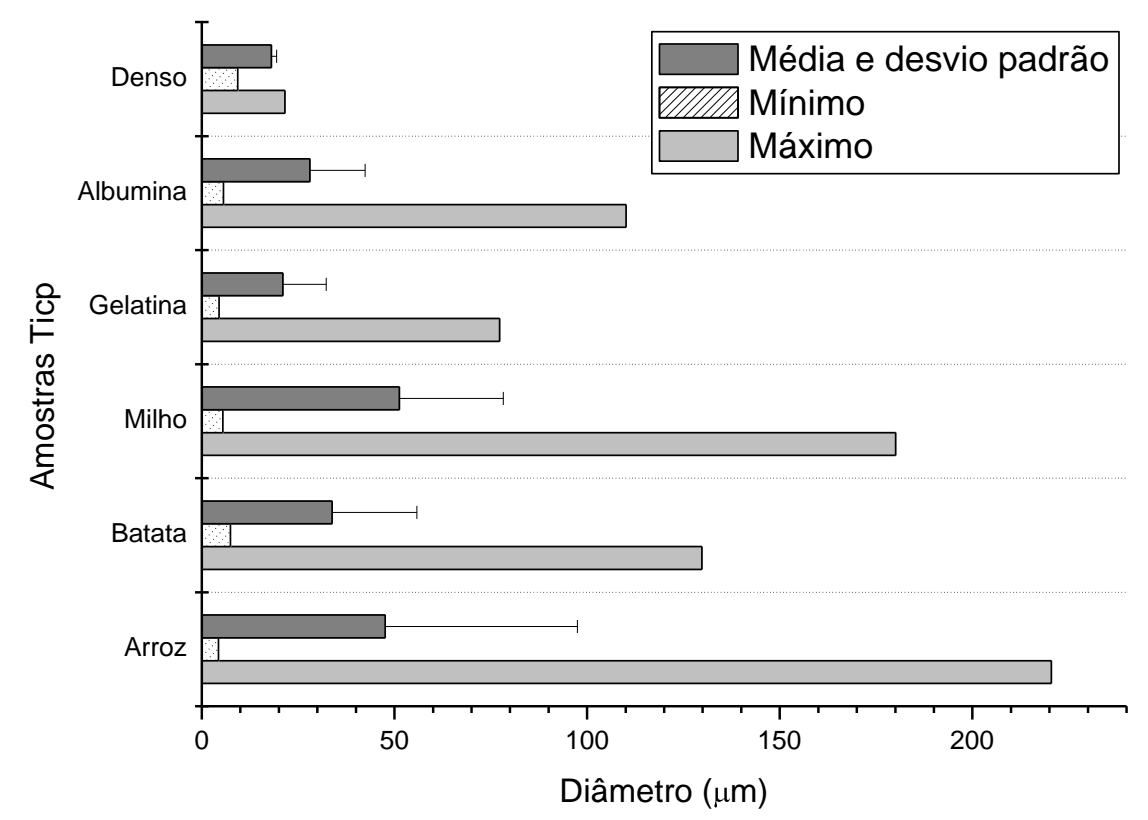

Figura 54. Análise do tamanho de poros por análise de imagem, amostras de Ticp.

As amostras do grupo poroso de liga possuem as fases $\alpha$ e $\beta$, difratograma, Figura 55. As amostras com adição de gelatina apresentam a fase TiO, diferente das demais amostras. Uma provável explicação para isso ocorrer, seria que durante o processo de tratamento térmico houve a expansão volumétrica da amostra, aumentando significativamente a área de superfície específica da amostra, propiciando a detecção do óxido na estrutura (Figura 59A).

As amostras possuem microestrutura homogênea (Figura 56, Figura 57, Figura 58, Figura 59) apesar da porosidade elevada. As fases $\alpha$ e $\beta$ formam a estrutura Widmanstatten comprovando a boa difusividade dos elementos $\beta$ estabilizadores da Liga $\mathrm{Ti}-13 \mathrm{Nb}-13 \mathrm{Zr}{ }^{51}$. 
Para o grupo de amostras da Liga Ti-13Nb-13Zr há semelhança entre os resultados em relação à porosidade, a maioria em torno de $60 \%$ e as amostras com gelatina com $68 \%$ de porosidade. Houve dificuldade em mensurar o tamanho de poro das amostras, pois $60 \%$ de porosidade representa mais poros do que estrutura. As amostras obtidas com adição de amido de arroz apresentam os maiores diâmetros (167 $\mu \mathrm{m}$ ) quando comparado às amostras com adição dos outros polímeros naturais (Figura 60). As amostras com adição de amidos apresentam porosidade com aspecto mais homogêneo, embora com diferentes distribuições de tamanho de poros. Já nas amostras com adição de gelatina foram observados macroporos na estrutura (Figura 56, Figura 57, Figura 58, Figura 59).

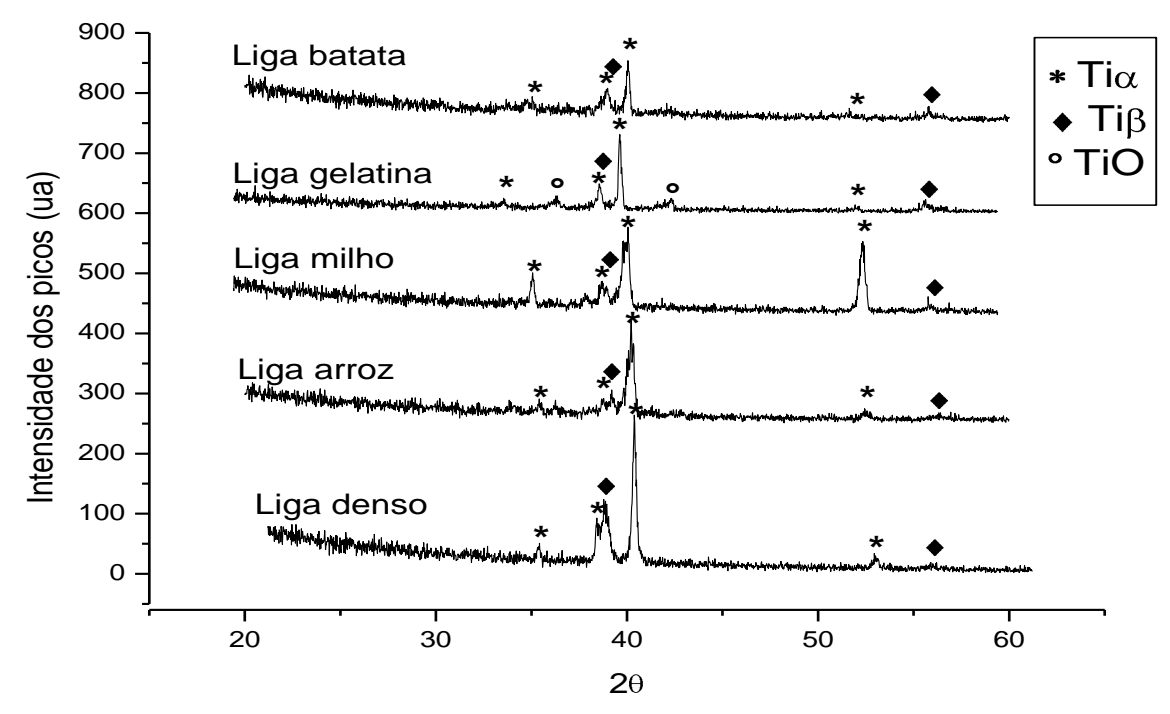

Figura 55. DRX das amostras do grupo poroso da Liga com adições de: gelatina, amido de batata, amido de milho, amido de arroz e o controle denso. Presença das fases a e $\beta$, e na amostra com adição de gelatina houve a formação da fase TiO. 

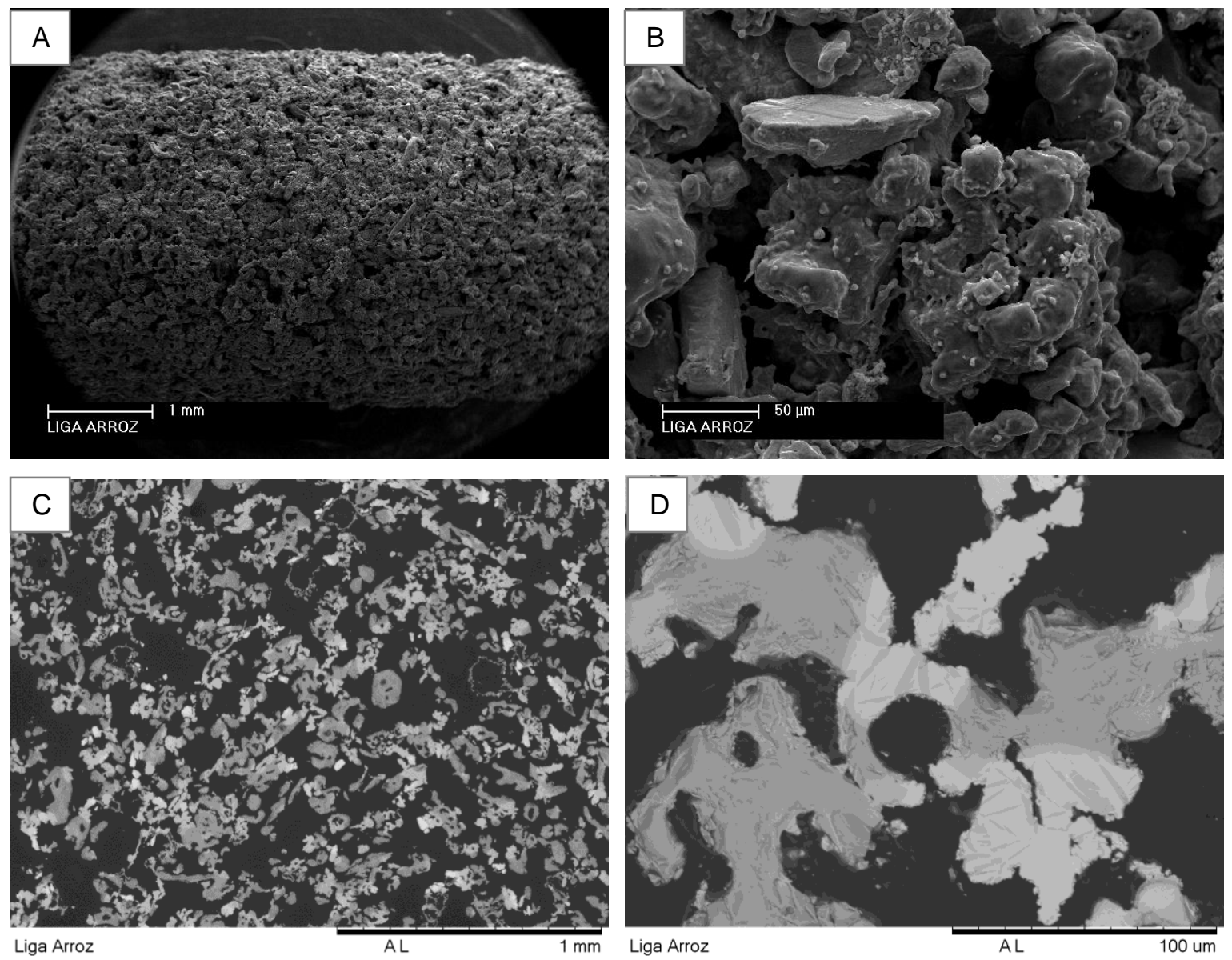

Figura 56. MEV da superfície da amostra de Liga porosa com adição de $16 \%$ de amido de arroz: A) visualização da rugosidade da amostra, B) topografia após sinterização. MEV da microestrutura: C) poros distribuídos na microestrutura, D) irregularidade dos poros. 

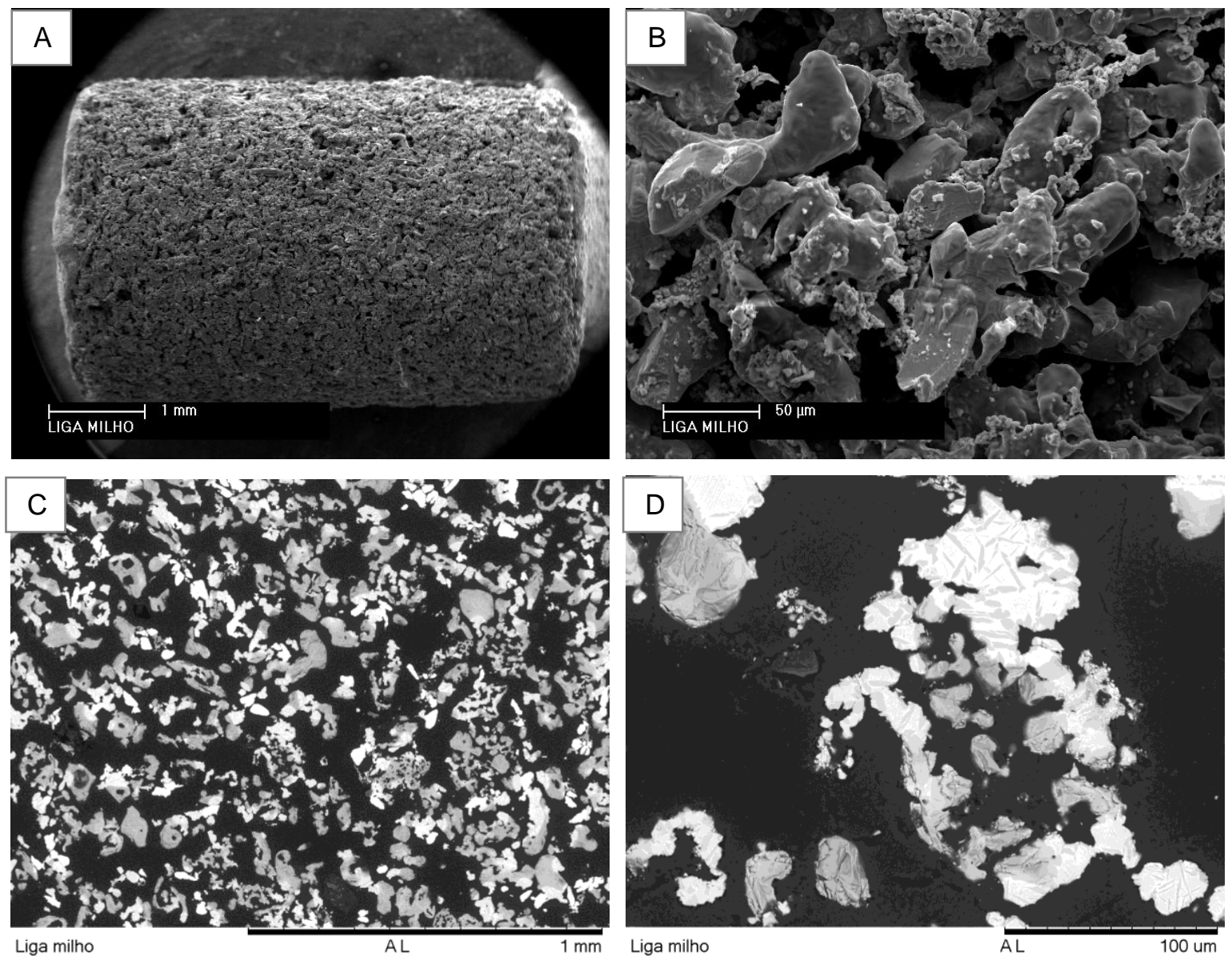

Figura 57. MEV da superfície da amostra de Liga porosa com adição de $16 \%$ de amido de milho: A) visualização da rugosidade da amostra, B) topografia após sinterização. MEV da microestrutura: C) poros distribuídos na microestrutura, D) irregularidade dos poros. 

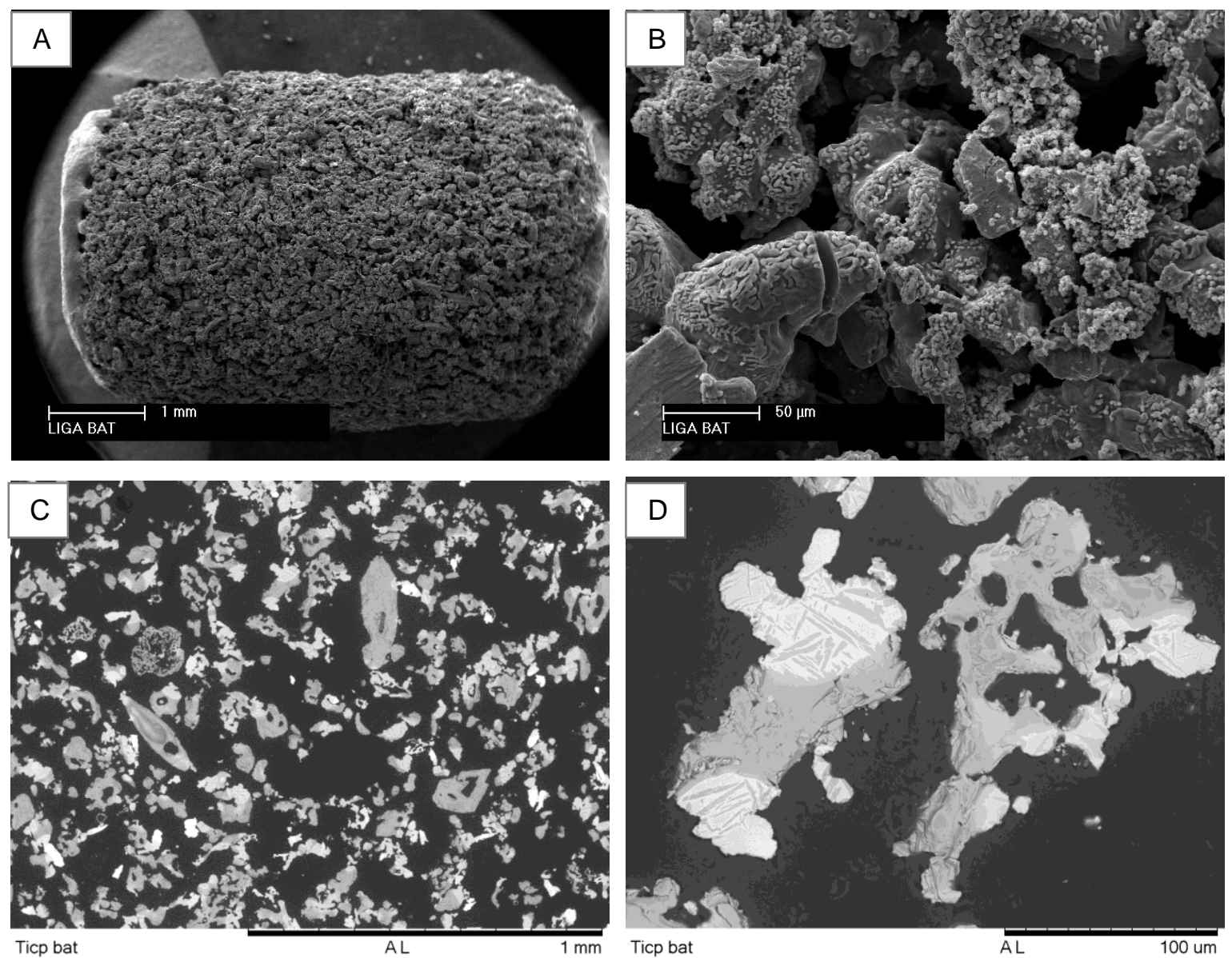

Figura 58. MEV da superfície da amostra de Liga porosa com adição de $16 \%$ de amido de batata: A) visualização da rugosidade da amostra, B) topografia após sinterização. MEV da microestrutura: C) poros distribuídos na microestrutura, D) irregularidade dos poros. 

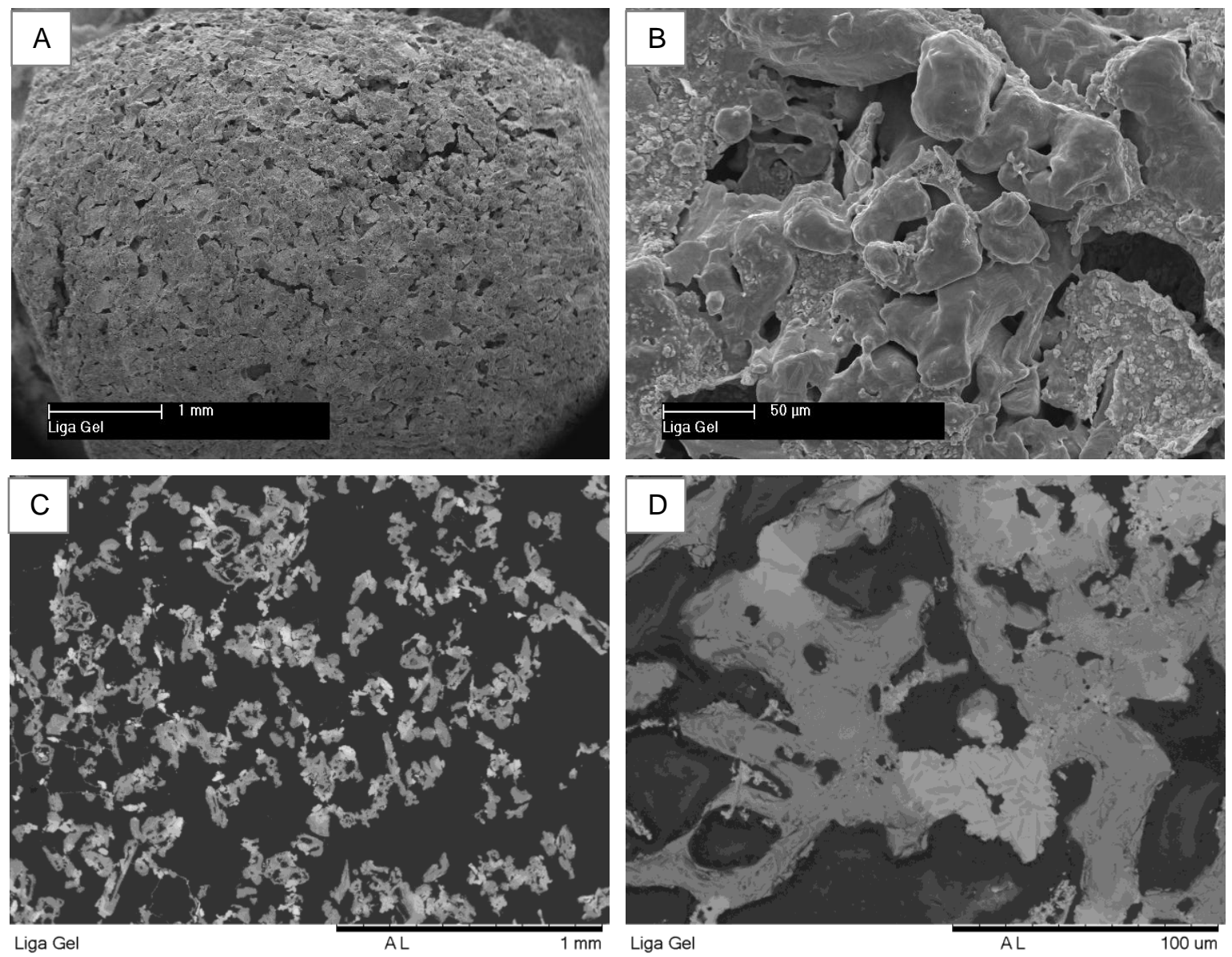

Figura 59. MEV da superfície da amostra de Liga porosa com adição de $16 \%$ de gelatina: A) visualização da rugosidade da amostra, B) topografia após sinterização. MEV da microestrutura: C) grandes áreas porosas na microestrutura, D) irregularidade dos poros. 


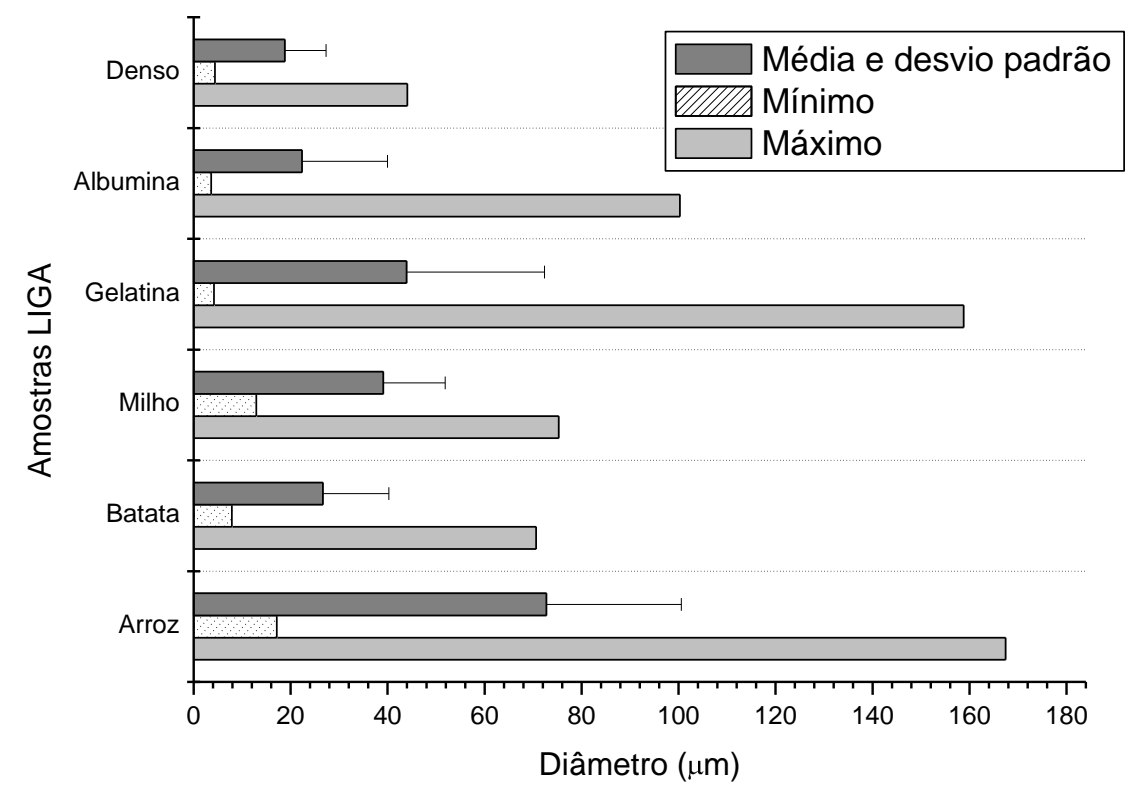

Figura 60. Análise do tamanho de poros por análise de imagem, amostras da Liga.

\subsection{Mimetização da estrutura do osso.}

A microarquitetura óssea é uma questão importante, pois está relacionada diretamente às propriedades biomecânicas do osso. Além disso, a microarquitetura é uma característica determinante para a qualidade do osso formado. A variação da microarquitetura natural acontece pela adaptação mecânica do osso em suportar cargas, combinadas a um número variado de fatores relacionados com nutrição, metabolismo, genética, doenças e envelhecimento ${ }^{91}$. As amostras obtidas foram comparadas à estrutura trabecular do osso.

Na Figura 61 é possível visualizar a microarquitetura do osso trabecular de tíbia de coelho. Considerando o aspecto global, com base na microestrutura das amostras, as amostras de Ticp obtidas com a adição de amido de arroz (Figura 63A) e as amostras de Liga Ti-13Nb-13Zr obtidas com a adição de gelatina (Figura 66B), resultaram poros heterogêneos similares a algumas regiões do tecido ósseo de coelho (Figura 61A). A porosidade homogênea também é verificada no tecido ósseo (Figura 61B), portanto as demais amostras com porosidade homogênea também são condizentes com a mimetização da estrutura óssea (Figura 62, Figura 63, Figura 64, Figura 65, Figura 66). 0 tamanho dos poros corresponde à estrutura óssea e formatos semelhantes foram obtidos. A variação do tamanho dos poros nas amostras porosas foi de aproximadamente 
$100 \mu \mathrm{m}$ a $400 \mu \mathrm{m}$. Conforme relatado na literatura em implantes porosos, o tamanho dos poros é responsável por permitir a deposição óssea adequada, a remodelação e nutrição pela vasculatura neoformada, sendo importante para permitir, que o crescimento ósseo durante o processo de reparação ocorra corretamente ${ }^{16}$. A busca por mimetizar a microarquitetura do tecido ósseo, destina-se a facilitar o processo de integração óssea devido às suas semelhanças morfológicas e funcionais. Para adequar esta mimetização do material ao tecido ósseo, deve-se levar em consideração a localização e tipo de microarquitetura no sítio de implante, quanto mais trabeculado a região do osso, mais poroso deve ser o implante. Levando em consideração que as transferências de cargas e resistência são diferentes em cada região do osso, como foi observado neste estudo pela análise por MEV da tíbia de coelhos.
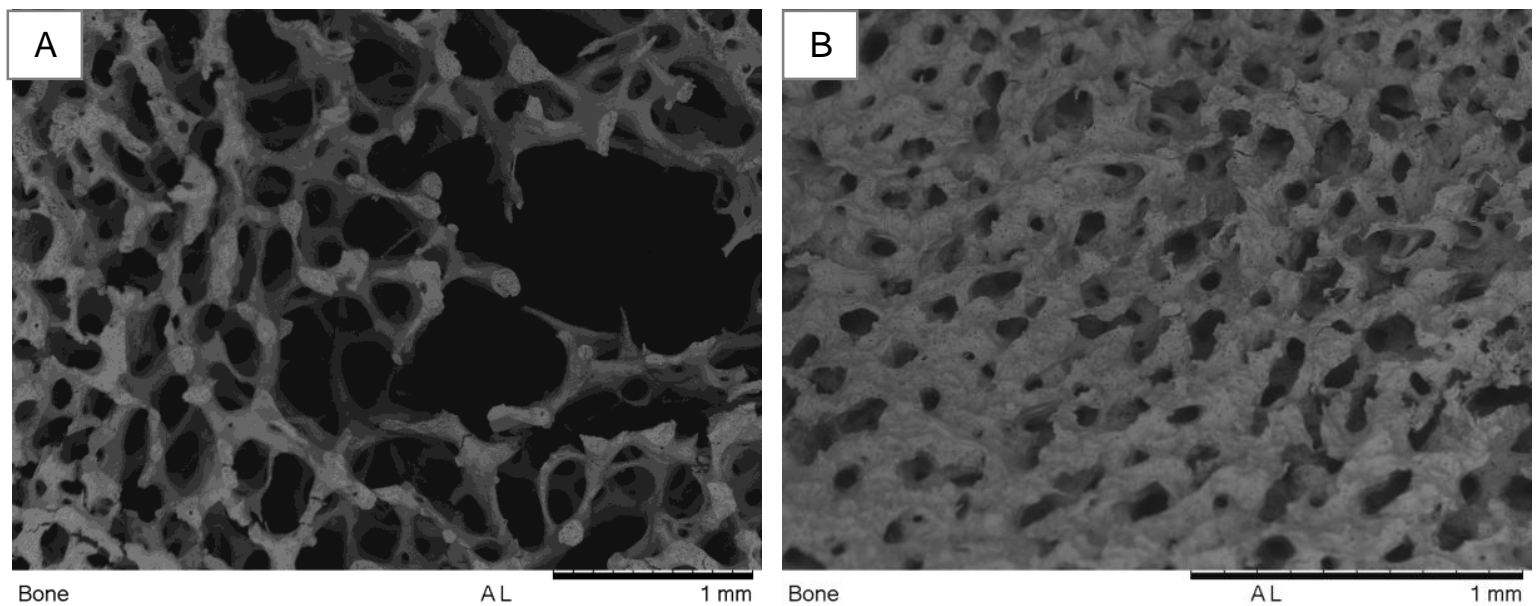

Figura 61. MEV, microarquitetura do osso trabecular da tíbia proximal de coelho: A) região com poros heterogêneos, B) região com poros homogêneos.
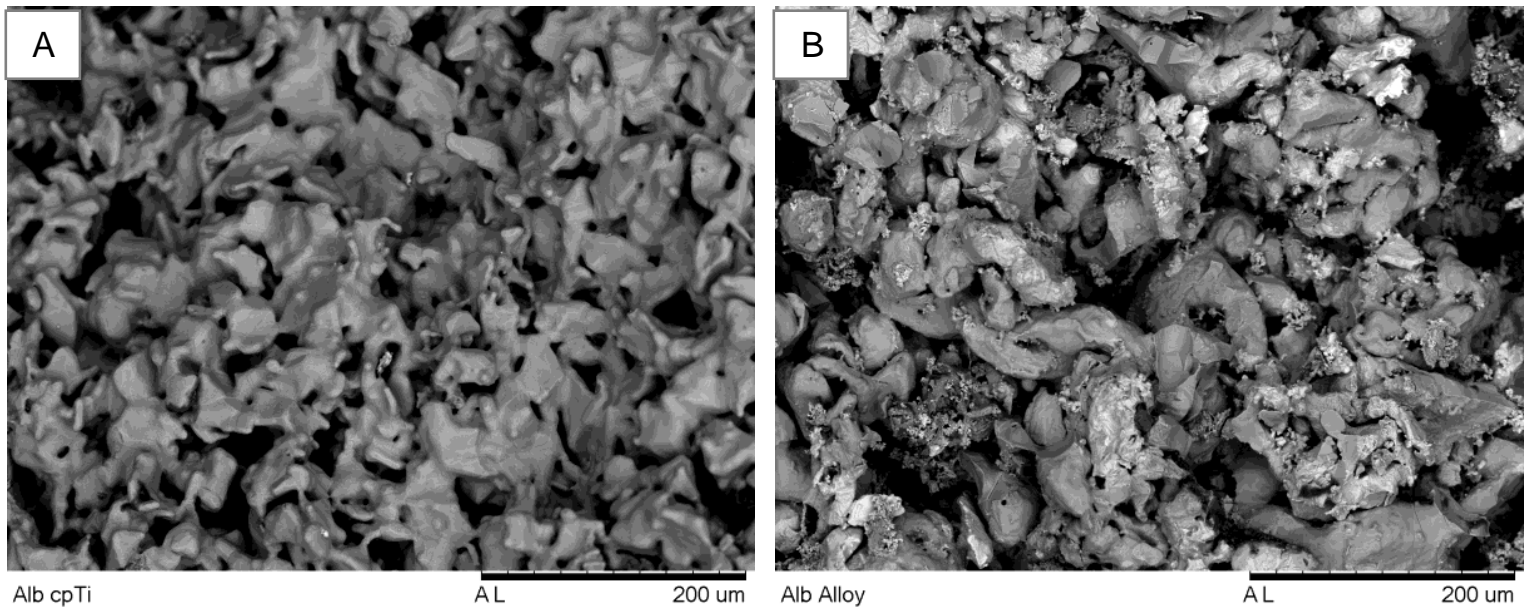

Figura 62. Microarquiteturas das amostras com adição de albumina: A) Ticp, B) Liga. 

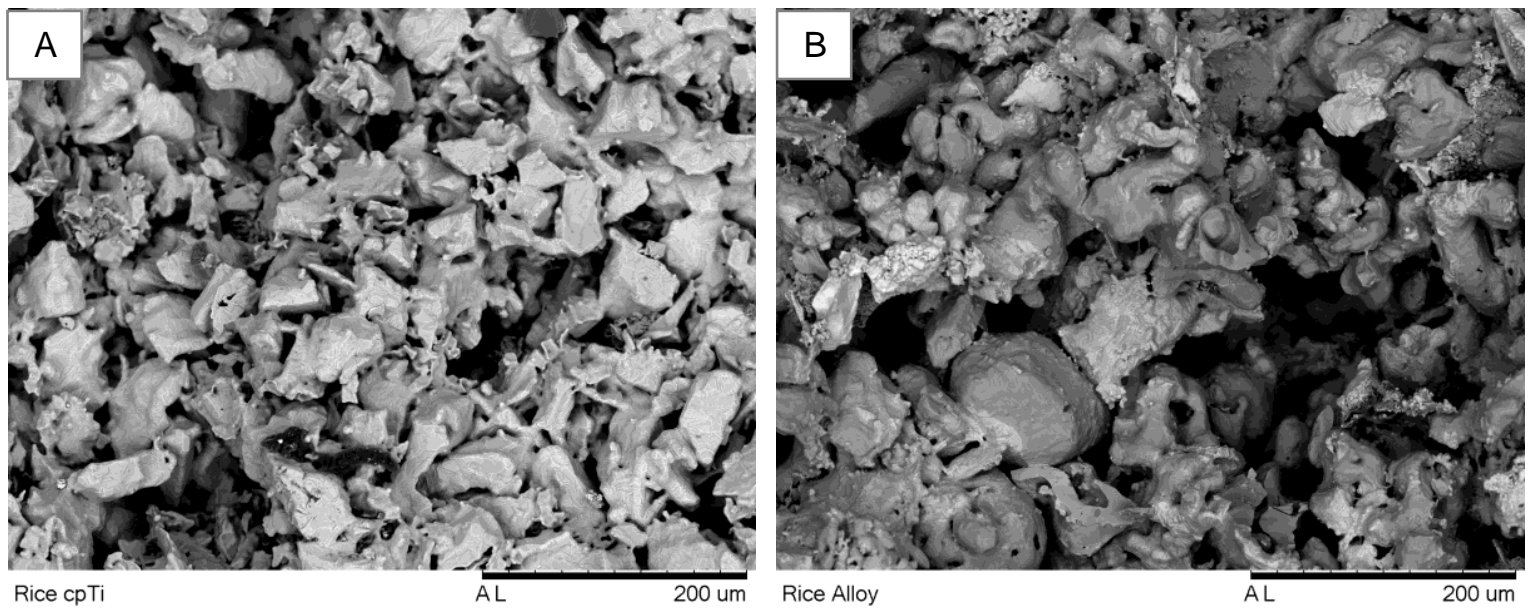

Figura 63. Microarquiteturas das amostras com adição de amido de arroz: A) Ticp, B) Liga.
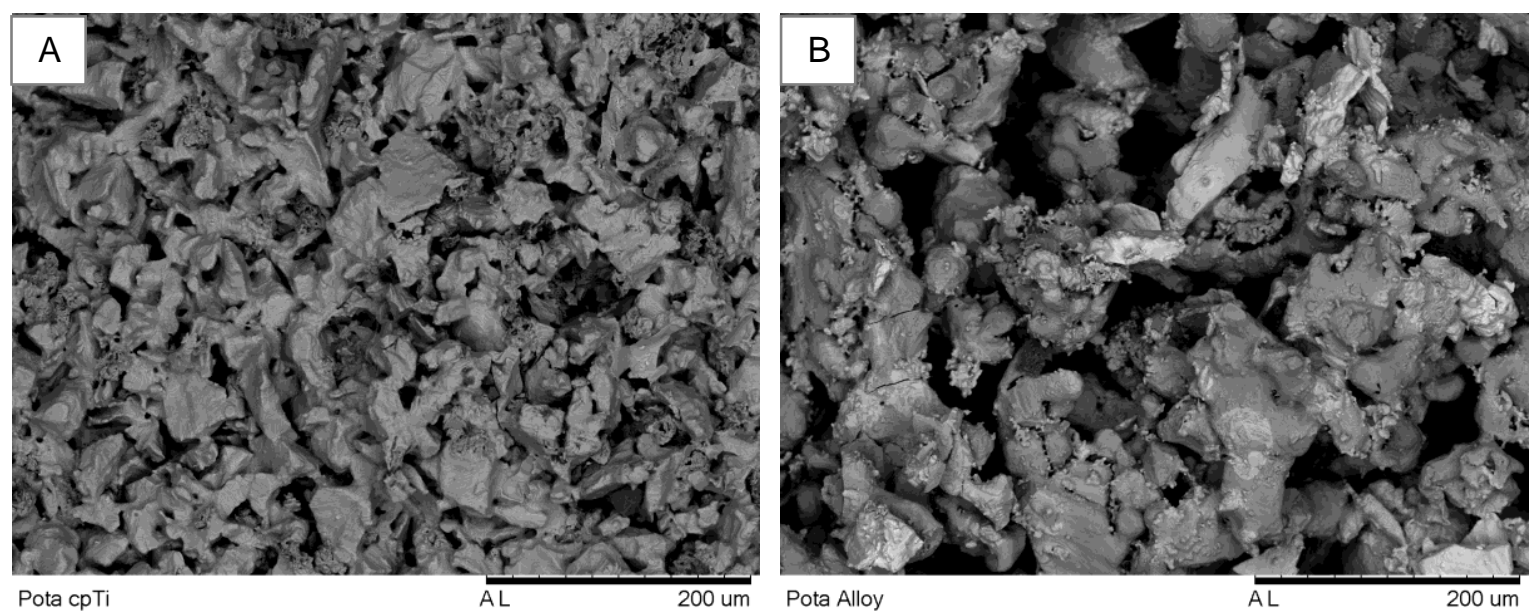

Figura 64. Microarquiteturas das amostras com adição de amido de batata: A) Ticp, B) Liga.
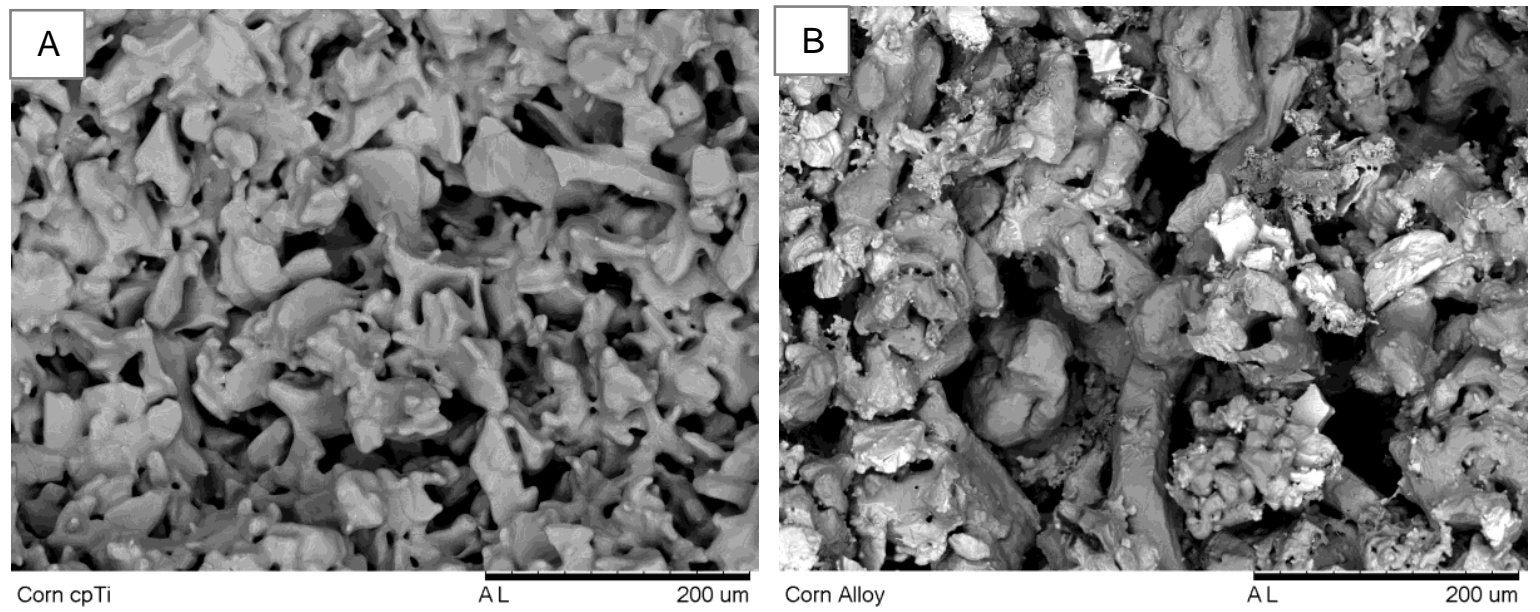

Figura 65. Microarquiteturas das amostras com adição de amido de milho: A) Ticp, B) Liga. 

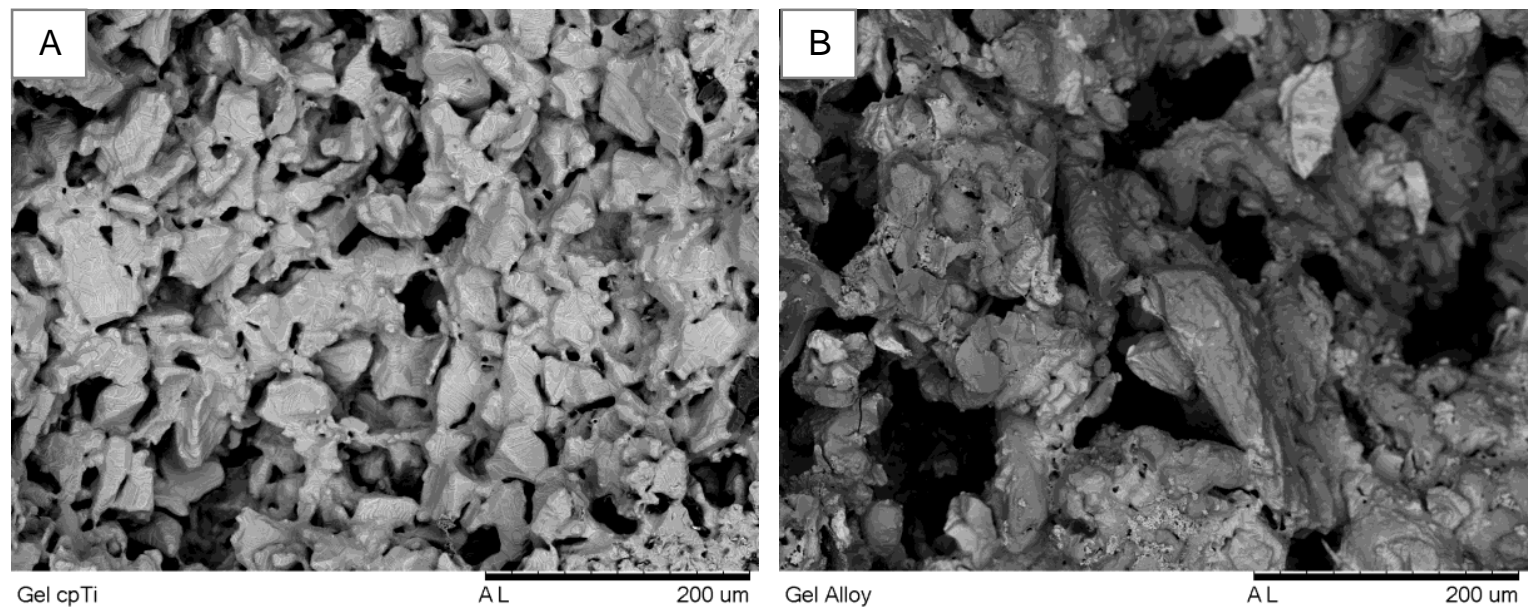

Figura 66. Microarquiteturas das amostras com adição de gelatina: A) Ticp, B) Liga.

\subsection{Caracterização biológica}

A caracterização biológica consiste em avaliar os materiais desenvolvidos em sistemas biológicos, observando as respostas de células, tecidos e organismos frente esses materiais, e validar os mesmos e seus processos de obtenção.

Para tal, uma serie de processamentos devem ser seguidos, com o intuito de assegurar o bom desempenho do material. Desses procedimentos tem-se a esterilização dos materiais, para garantir que não ocorra contaminação por microrganismos ou infecções, que se faz necessária tanto para o ensaio in vitro de citotoxicidade quanto para o ensaio in vivo de implantação. Os ensaios seguem normas e são realizados de acordo com os respectivos procedimentos normativos e diretrizes de bioética.

Todo biomaterial deve sofrer um processo de esterilização para eliminar patógenos que podem causar infecções, comprometendo a eficiência do biomaterial e/ou o processo de reparação do organismo. Salvo algumas exceções, como por exemplo, alguns polímeros que teriam sua estrutura ou função comprometida por alguns métodos de esterilização ${ }^{92}$.

A esterilização por calor seco, ou estufa, é o método mais antigo de esterilização, bem simples e seguro, necessita de temperaturas elevadas e tempo prolongado para atingir o objetivo da esterilização. Para melhorar o desempenho da esterilização por calor, a autoclave utiliza pressão e umidade para diminuir a temperatura do processo e aumentar a eficiência, com a penetração do calor com auxilio do vapor pressurizado conseguindo quebrar proteínas não priônicas, vírus, bactérias e esporos. Apesar da eficiência, materiais metálicos podem ser prejudicados durante estes processos por 
oxidação da superfície e corrosão. O titânio e suas ligas são amplamente utilizados como biomateriais principalmente pela característica de resistência à corrosão, porém ao se trabalhar com materiais porosos, a área de superfície aumenta vertiginosamente, aumentando a probabilidade de formação de camada óxida, ou o rompimento da camada passivadora, responsável pela característica de resistência à corrosão ${ }^{92}$.

A esterilização por óxido de etileno envolve procedimento com a utilização de gás inflamável. Apesar de ser aceito por muitos tipos de materiais por não agredir a estrutura, esse tipo de esterilização requer a descontaminação do gás e não é efetivo em materiais previamente embalados, já que o mesmo precisa penetrar fisicamente para o efeito esterilizante. A radiação gama, diferente dos métodos de esterilização descritos anteriormente, apresenta como vantagens a completa penetração no material, variando dose e tempo, conforme o tamanho do objeto, e imediata liberação do material, sem presença de resíduos, sendo ambientalmente seguro. $O$ efeito da esterilização ocorre graças à característica ionizante da radiação gama, que induz quebras nas moléculas, como por exemplo, cadeias de DNA dos micro-organismos, que bloqueia a reprodução ou o metabolismo celular, ocorrendo subsequentes desestabilizações dos elementos que compõe desde ácidos nucleicos até proteínas. A única desvantagem da radiação gama é em relação a alguns produtos poliméricos que sofrem degradação pela quebra de suas ligações ${ }^{92}$.

A radiação gama foi a técnica de esterilização eleita para este trabalho por ser bastante eficiente e efetiva em materiais metálicos.

\subsubsection{Ensaios in vitro}

Em cultura celular frequentemente são utilizadas células de tecidos variados, cada qual para avaliar a compatibilidade e resposta biológica quando em contato com diferentes biomateriais. Estes estudos antes de avaliar qualquer função celular elaborada, avaliam primeiramente a citotoxicidade frente às células ${ }^{10}$.

As ligas de titânio exibem baixa taxa de liberação de íons devido a alta resistência à corrosão, que é geralmente afetado pelo meio (solução) e pela diminuição do $\mathrm{pH}^{93}$. Existem evidências de que as ligas de titânio com elementos $\beta$ - estabilizadores, como, $\mathrm{Nb}, \mathrm{Zr}$ e Ta, liberam íons em menores quantidades do que ligas contendo Al e V. A presença dos elementos $\mathrm{Nb}$, $\mathrm{Zr}$ e Ta na liga resultam em uma camada passivadora de $\mathrm{TiO}_{2}$ mais resistente, que os torna adequados para utilização como implantes de longa duração ${ }^{94}$. 
Os elementos titânio, nióbio e zircônio, separadamente, não apresentam características de toxicidade, sendo considerados materiais inertes para o sistema biológico ${ }^{95}$. Porém, modificações durante o processo de obtenção do implante podem influenciar as características finais do material. Em se tratando de um biomaterial, o teste de citotoxicidade determina a resposta biológica de células de mamíferos in vitro usando parâmetros biológicos apropriados. Neste teste, a interceptação das curvas analisadas com concentração inibitória $\left(\mathrm{Cl}_{50 \%}\right)$ determina o grau de toxicidade da amostra. No gráfico, a curva obtida para cada amostra correlaciona o porcentual médio de células vivas em função da concentração dos extratos. Dois parâmetros foram utilizados para avaliar a citotoxicidade dos materiais: o controle negativo, um material de características conhecidas que não produz resposta de citotoxicidade, neste caso o Ticp e Liga Ti-13Nb$13 \mathrm{Zr}$ sem adições de materiais formadores de poros; e o controle positivo, que reproduz uma resposta de citotoxicidade, como a solução fenol 0,3\%.

No teste de citotoxicidade nenhuma das amostras apresentou $\circ \mathrm{Cl}$ abaixo de $50 \%$, ou seja, os processos para obtenção de materiais com estruturas porosas variadas, não apresentam citotoxicidade, viabilizando a utilização dos mesmos como implantes nos ensaios in vivo (Figura 67, Figura 68).

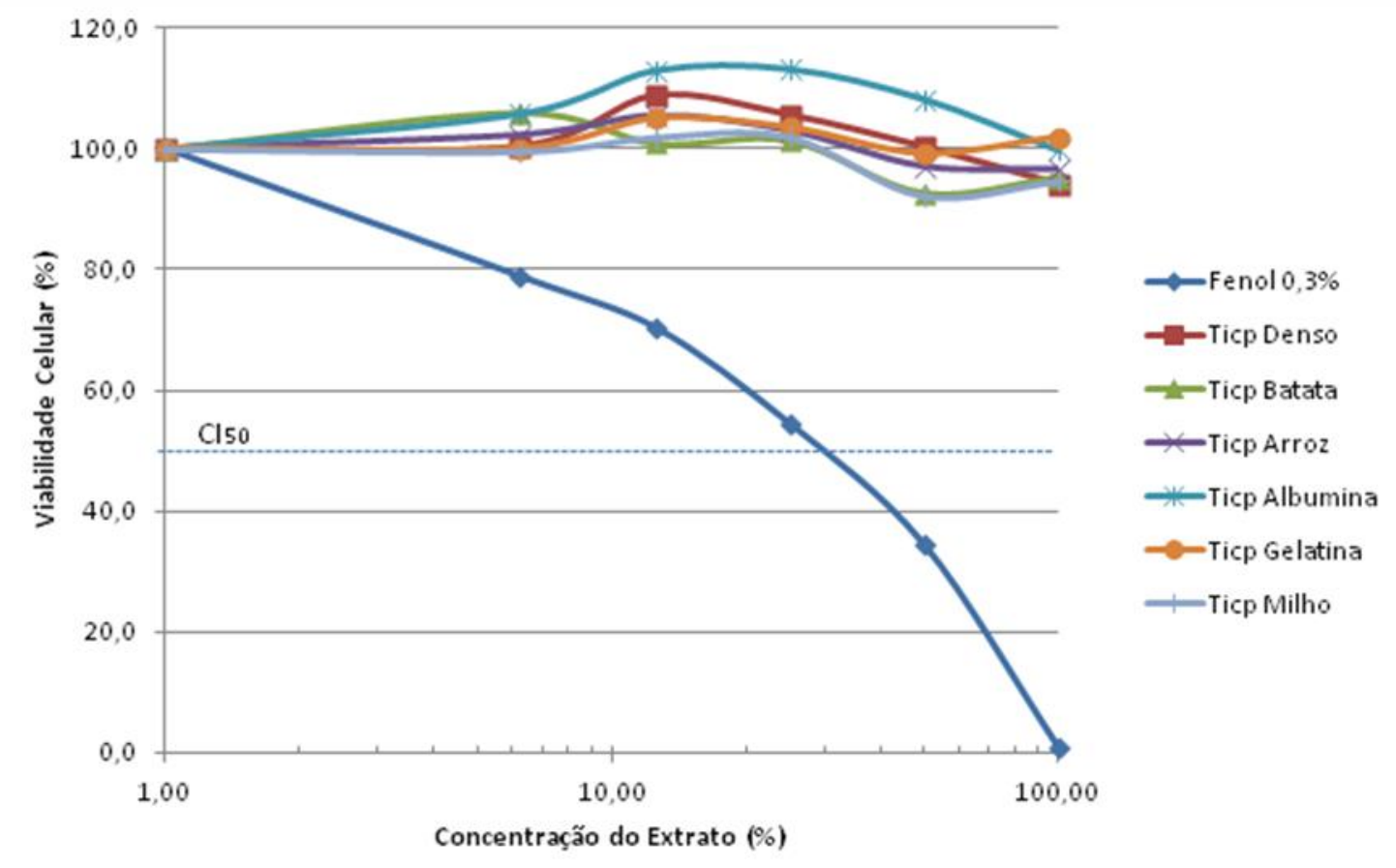

Figura 67. Gráfico de avaliação da citotoxicidade das amostras sinterizadas: Ticp batata, Ticp arroz, Ticp albumina, Ticp gelatina e Ticp milho. Sendo o controle negativo Ticp denso e controle positivo solução fenol 0,3\%. 


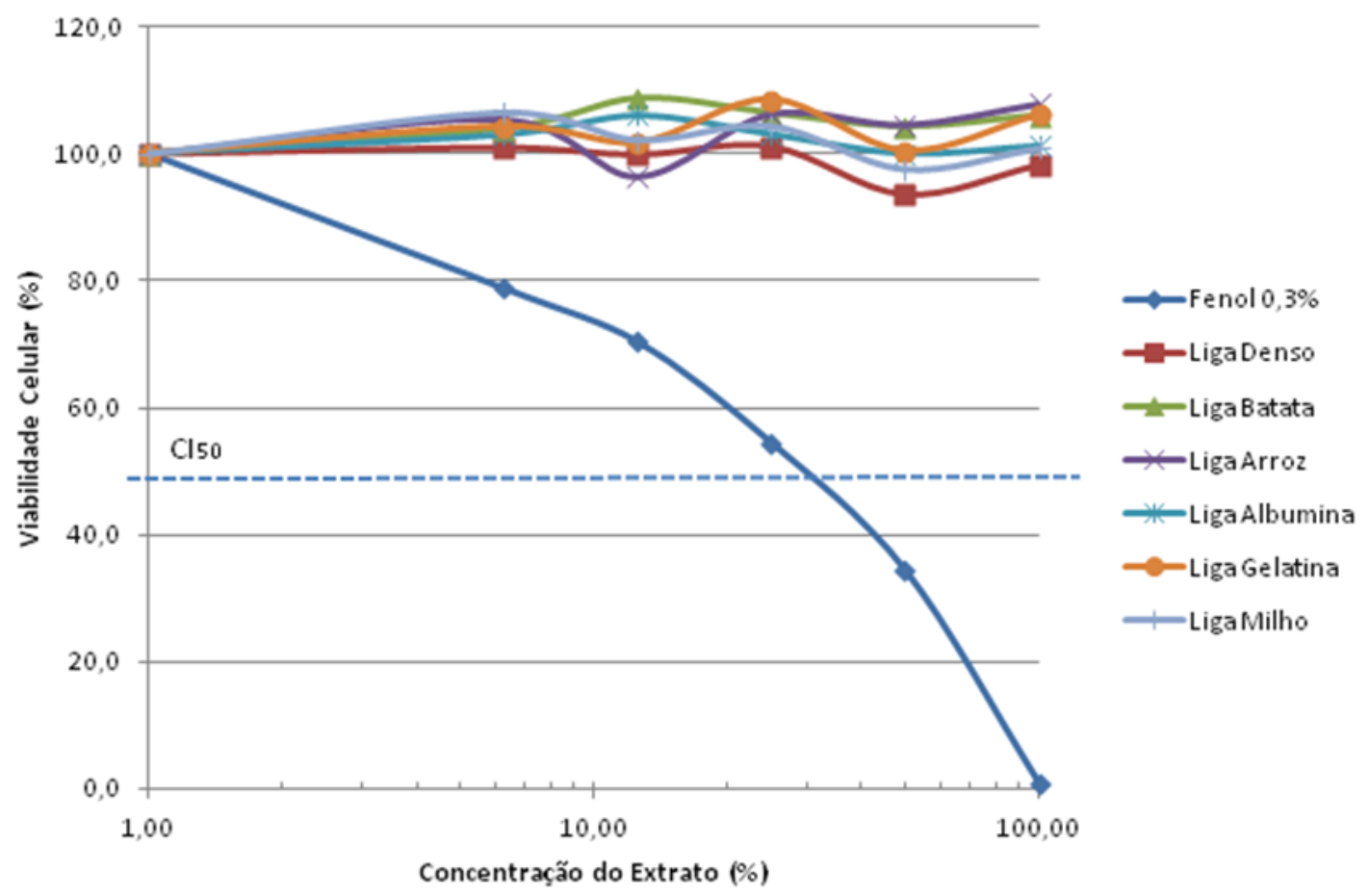

Figura 68. Gráfico de avaliação da citotoxicidade das amostras sinterizadas: Liga batata, Liga arroz, Liga albumina, Liga gelatina e Liga milho. Sendo o controle negativo Liga densa e controle positivo solução fenol $0,3 \%$.

\subsubsection{Ensaios in vivo}

Segundo a legislação brasileira, PORTARIA № 2.661/MS/SVS, de 20 de dezembro de 1995 (http://www.anvisa.gov.br/legis/portarias/2661 95.htm) somente é permitida o emprego de biomateriais em seres humanos após testes prévios em animais. O teste in vivo, tem por finalidade avaliar o comportamento clínico, histológico, mecânico, e as reações orgânicas desencadeadas pelo biomaterial em um modelo animal. Apesar da diferença entre as espécies, o teste visa avaliar a resposta do animal quando do emprego final do material, assim prediz informações sobre as possíveis reações teciduais e do organismo, induzidas pela interação com o material. Permite descartar materiais que induzem resultados negativos ou adversos para o tecido em estudo, antes de efetuar estudos mais avançados e testes pré-clínicos para a utilização em humanos.

A decisão de escolher o melhor modelo animal para um estudo específico demanda uma extensiva revisão de literatura para adequar o material, ao teste, ao animal, à resposta esperada, sempre em relação ao ser humano, que é o destino final do biomaterial. A revisão, não deve ser focada apenas no material a ser implantado em um 
sistema específico, fatores como fisiologia e natureza química do sistema devem ser ponderados, e todas estas questões devem estar relacionadas à aplicabilidade final, em humanos ${ }^{96}$.

O modelo animal ideal deve reproduzir as características que simulem condições análogas ou homólogas em resposta ao biomaterial que será utilizado clinicamente. Por esta razão a anatomia, a bioquímica, a fisiologia, a patologia devem ser consideradas dependendo da aplicação do biomaterial no modelo animal selecionado ${ }^{96}$.

Em se tratando de reparo de tecido ósseo e a reação aos biomateriais, o modelo animal que mais se assemelha com humanos é a cabra, embora esse animal seja ruminante e, portanto possua diferenças fisiológicas significativas. O tempo de reparo, tipo celular, estrutura de colágeno e a organização de tecidos moles e duros, são características importantes na avaliação da reparação do tecido ósseo. Por outro lado, a contraindicação de animais que apresentam resposta diferente do homem devem ser consideradas: como em ovelhas que tendem a ter calcificações em tecido mole durante a reparação; cães da raça beagles que desenvolvem condrodistrofia, apesar de serem modelo de escolha em se tratando de doença periodontal e recessão gengival ${ }^{96}$.

O local de implantação no tecido ósseo também é um fator importante a ser considerado. A diferença de densidade e vascularização entre o osso cortical e esponjoso modifica a resposta do tecido ao trauma cirúrgico e consequentemente à capacidade de regeneração do osso. Os efeitos mecânicos sobre remodelação óssea, também apresentam desafios, principalmente na fase inicial da reparação. No homem protocolos de imobilização apropriados minimizam esse fator, diferente no modelo animal que é bem difícil tal imobilização. Para a avaliação da reparação em osso cortical, o cão representa o modelo selecionado como a melhor alternativa para este teste, sendo os leitos cirúrgicos de eleição a metáfise proximal e distal do fêmur e proximal da tíbia. Os coelhos, apesar da restrição do tamanho do animal e consequentemente áreas reduzidas do leito cirúrgico, são considerados modelos para estudos translacionais, ou seja, podem antever estudos pré-clínicos e clínicos de primeira fase ${ }^{96}$. Portanto, o coelho foi o modelo animal escolhido para esta etapa da pesquisa.

Neste estudo foram confeccionados implantes com dimensões de 2 a $3 \mathrm{~mm}$ de diâmetro e $5 \mathrm{~mm}$ de comprimento, tamanho ideal para o modelo animal escolhido ${ }^{97}$. Dez coelhos foram utilizados, e instalados 6 implantes de mesma composição metálica com diferentes porosidades ( 3 em cada tíbia) em cada coelho. Os implantes densos e usinados foram utilizados como grupo controle do experimento. 


\subsubsection{Experimentação animal}

$\mathrm{Na}$ avaliação da osteointegração é de suma importância diminuir o número de variáveis que possam interferir no resultado final. Por esta razão cuidados e precauções antes, durante e depois do procedimento cirúrgico são necessários. A anestesia e analgesia que precedem a cirurgia devem seguir o protocolo farmacológico para cada espécie, assim como a administração de antimicrobianos profiláticos.

A exposição da loja cirúrgica é precedida pela incisão e divulsão dos tecidos moles, que deve ser feita cuidadosamente, respeitando a anatomia e preservando o periósteo, tecido responsável pela nutrição e manutenção de células osteoblásticas ${ }^{98}$. A reparação do tecido ósseo está diretamente relacionada a estas células, que sintetizam os componentes orgânicos da matriz ${ }^{7}$.

A correta instalação dos implantes depende da habilidade e técnica do cirurgião. O procedimento de osteotomia deve ter o tempo reduzido à medida que a temperatura gerada pelo atrito da broca com o osso aumenta, esse aumento pode causar necrose óssea induzida pela alta temperatura. Essa necrose óssea ocorre após 7 minutos, a $40^{\circ} \mathrm{C}$, ou 1 minuto, a $47^{\circ} \mathrm{C}$, para impedir que a necrose ocorra é indicado a utilização de brocas novas, com design otimizado, refrigeração por irrigação constante com solução salina estéril ${ }^{98}$, procedimentos que foram observados e seguidos para impedir a morte celular óssea.

O tempo da reparação óssea em cada espécie difere, embora os eventos que se sucedem, com poucas exceções, são orquestrados da mesma maneira. A diferença no tamanho do animal está relacionada diretamente com o metabolismo do mesmo, animais menores, com metabolismo mais rápido possuem um tempo de reparação menor em relação seus confrontantes animais maiores; subentendendo não apenas o tamanho ser exatamente o fator responsável, mas sim o metabolismo celular que afeta essa variável. Passado o tempo de reparação relativo à espécie animal em relação ao tempo que se espera de um humano é necessário proceder com a eutanásia desses animais e correta remoção das amostras para análise. O método de eutanásia empregado buscou cumprir todos os preceitos de bioética, para minimizar qualquer sofrimento do animal durante o processo de eutanásia, com a insensibilização anestésica em plano profundo. Animais maiores podem sofrer a intervenção cirúrgica de retirada da amostra sem a necessidade de eutanásia podendo assim, utilizar o mesmo animal para múltiplos implantes por um período de tempo maior. A remoção das amostras do conjunto osso/implante foi realizada com critério, para não criar artefatos ou defeitos na análise devido manipulação e 
deslocamento dos implantes. As amostras removidas foram rapidamente fixadas para manterem a estrutura morfológica ${ }^{99,100}$.

A Figura 69 ilustra duas amostras osso-implante removida das tíbias esquerda e direita de um animal após 7 semanas. Foi observado em exame macroscópico das peças que houve a formação de osso recobrindo os implantes, porém a espessura desse osso formado variou entre os implantes. O exame radiográfico permitiu a visualização dos implantes internamente ao osso, assim como a inclinação e posicionamento dos implantes com relação à peça. Essas informações são importantes para guiar os cortes do tecido osso/implante após o processamento e emblocamento em resina, para o maior aproveitamento do tecido a ser analisado em relação ao implante.

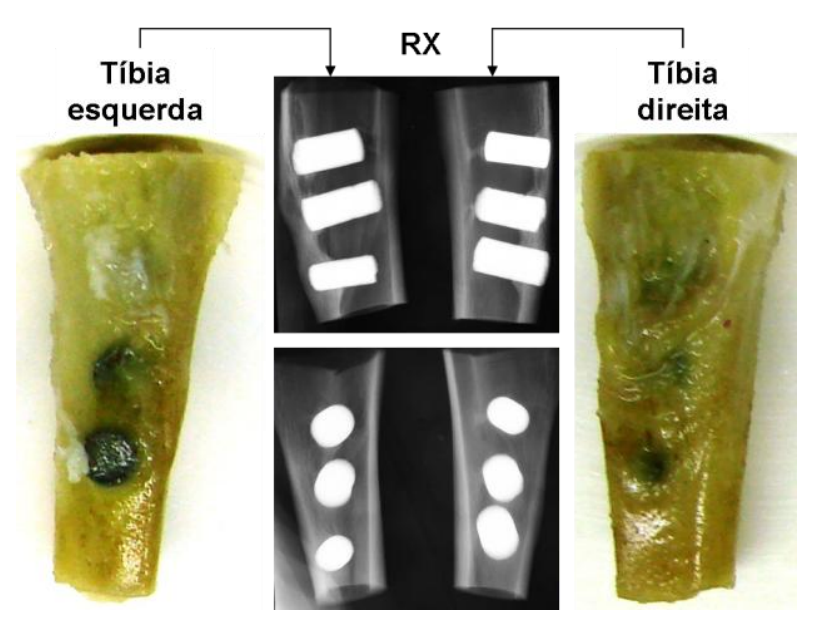

Figura 69. Amostras osso-implante das tíbias: esquerda e direita. No centro da figura, duas radiografias referentes às amostras em dois planos distintos.

\subsubsection{Análise histológica}

Para a avaliação histológica de tecidos é necessária a preparação de lâminas com cortes de apenas alguns micrometros de espessura. A presença da matriz mineralizada dificulta a utilização do micrótomo para os cortes finos, porém a descalcificação do tecido em uma solução ácida (ácido fórmico 10\%) ou quelante (EDTA) permite o processamento de tecido ósseo pela metodologia convencional por emblocamento em parafina ${ }^{7}$. 0 processamento dos tecidos com biomateriais é dificultado para avaliação histomorfológica, quando o biomaterial implantado não é dissolvido pela solução descalcificadora juntamente com o osso. Na análise da interface do osso com implantes, metálicos e alguns cerâmicos, estes são removidos antes do processamento do tecido 
para proceder com o método convencional ${ }^{101}$. No caso de biomateriais porosos, ao remover o material implantado perdem-se todas as informações desejadas, como a ocorrência do fenômeno de "bone-ingrowth" (invasão tecidual no interior dos poros). Assim, foi realizado o emblocamento do tecido em resina, para obter cortes seriados das amostras do conjunto osso-implante, com serra diamantada circular e irrigação constante, seguido de desgaste e polimento até alcançar espessuras da ordem de $30 \mu \mathrm{m}$, permitindo obter lâminas de tecido ósseo sem a necessidade de descalcificação com a presença in loco do implante ${ }^{78}$.

A fluorescência é o método de identificação de tecido ósseo que avalia as fases do processo de reparação do osso. Marcadores ósseos foram aplicados sistemicamente nos coelhos, e pela afinidade com o cálcio, eles se depositam na apatita do osso novo. Sob luz de lâmpada de vapor de mercúrio e filtros específicos para cada marcador, foi possível visualizar linhas que representam a deposição do marcador durante o crescimento ósseo, e relacioná-las de acordo com a fluorescência emitida com o tempo e marcador administrado ${ }^{78,79}$. A importância desta técnica, além de evidenciar as fases do crescimento ósseo, é aumentar a sensibilidade na avaliação dos poros, onde, sem o uso da fluorescência algumas áreas não poderiam ser identificadas por microscopia de luz convencional. $O$ aumento do sinal evidencia essas áreas juntamente com a mesma estratificação do crescimento celular em relação a cada marcador. A Tabela 6 apresenta o resultado qualitativo de intensidade de marcação com base em 1+, 2+ e 3+, sendo avaliados para cada fluoróforo no interior dos implantes, após a obtenção final da imagem.

Tabela 6. Análise qualitativa da intensidade de marcação fluorescente no interior dos implantes.

\begin{tabular}{cl|ccc}
\hline \multirow{2}{*}{ Implantes } & \multicolumn{3}{|c}{ Marcador fluorescente } \\
Tetraciclina & Alizarina & Calceína \\
\hline \multirow{4}{*}{ Ticp } & Denso & $2+$ & $1+$ & $3+$ \\
\cline { 2 - 5 } & Arroz & $2+$ & $2+$ & $3+$ \\
\cline { 2 - 5 } & Batata & $1+$ & $3+$ & $3+$ \\
\cline { 2 - 5 } & Milho & $1+$ & $1+$ & $3+$ \\
\cline { 2 - 5 } & Gelatina & $2+$ & $1+$ & $2+$ \\
\cline { 2 - 5 } & Albumina & $1+$ & $1+$ & $3+$ \\
\hline \multirow{4}{*}{ Liga } & Denso & $2+$ & $1+$ & $3+$ \\
\cline { 2 - 5 } & Arroz & $3+$ & $1+$ & $3+$ \\
\cline { 2 - 5 } & Batata & $2+$ & $1+$ & $3+$ \\
\cline { 2 - 5 } & Milho & $3+$ & $1+$ & $3+$ \\
\cline { 2 - 5 } & Gelatina & $2+$ & $2+$ & $2+$ \\
\cline { 2 - 5 } & Albumina & $3+$ & $3+$ & $3+$ \\
\hline
\end{tabular}


A avaliação dos cortes histológicos por MEV permite quantificar e qualificar o tecido ósseo no interior dos poros, além de apresentar maior sensibilidade na identificação de osso dentro do implante, em relação à técnica por fluorescência. Por MEV todo o osso que cresce no interior dos poros é evidenciado, sendo esse fator importante para a utilização desta técnica na avaliação de implantes metálicos porosos. $\mathrm{Na}$ fluorescência ocorre a identificação de fases de crescimento ósseo e áreas preenchidas em relação ao período pós-implantação. Na Figura 70, é possível observar microporos interligados preenchidos com tecido ósseo, comprovado pela presença de osteócitos aprisionados na matriz mineral. A quantificação do osso, poro e implante, foi feita para cada amostra por análise de imagem, e os resultados estão apresentados nos gráficos e figuras a seguir (Figura 71B-Figura 82B). A análise de EDS, apesar de ser um método semi-quantitativo, permite diferenciar as áreas metálicas, poros e osso. As áreas correspondentes ao osso formado foram identificadas pela presença de cálcio $(\mathrm{Ca})$ e fósforo $(\mathrm{P})$.

É comum a utilização das técnicas de coloração de histologia convencional para o estudo com implantes, porém, dificuldades durante o processamento podem comprometer o resultado e a análise final. No processo de emblocamento em resina, cada corte do bloco corresponde a uma lâmina histológica, tendo sido lixada e polida manualmente. Essa etapa foi realizada minuciosamente, pois existem problemas relacionados à fixação do corte à lâmina e o desgaste homogêneo do corte, considerando as diferentes características mecânicas do osso em relação ao metal, e cuidados com o arrancamento do tecido durante o polimento. As técnicas de coloração de tecido ósseo são bem estabelecidas para a histologia convencional de materiais descalcificados e emblocados em parafina. Para materiais calcificados e emblocados em resina, esses protocolos devem ser adaptados para serem válidos e oferecerem um resultado final confiável. A utilização dos recursos combinados MEV, EDS e microscopia por fluorescência padronizaram a análise dos resultados para estudos posteriores, pois proporcionaram uma maior confiabilidade e reprodutibilidade do processo, com boa sensibilidade na detecção de osso no interior dos poros, que é um dos objetivos na avaliação de biomateriais porosos. 

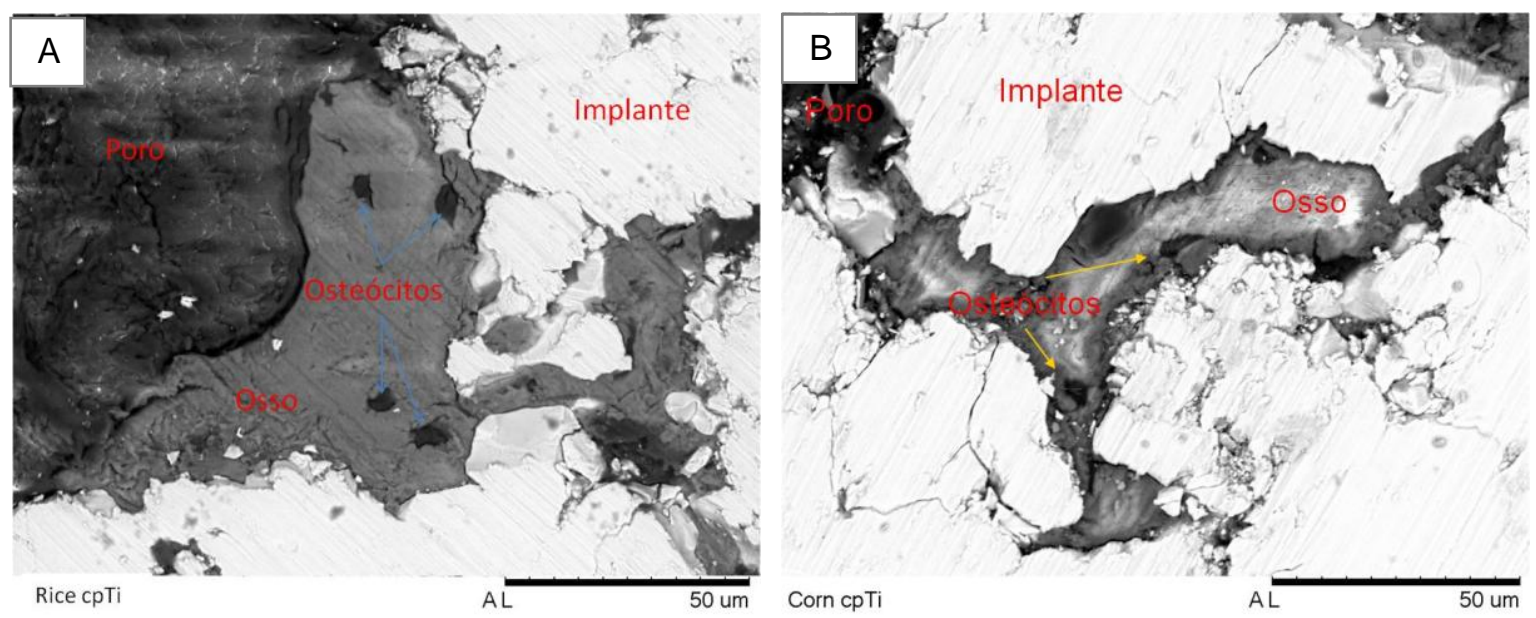

Figura 70. MEV do corte histológico representando a interação entre o osso e o implante poroso, os osteócitos estão indicados pelas setas: A) amostra Ticp com amido de arroz, B) amostra Ticp com amido de milho.

$\mathrm{Na}$ avaliação do grupo controle denso, para as duas formulações, Ticp e Liga Ti$13 \mathrm{Nb}-13 \mathrm{Zr}$, foi possível observar a osteointegração pelo crescimento de uma fina camada de tecido ósseo mineralizado na superfície usinada do implante, caracterizando o aspecto osteocondutivo dos implantes de Ticp e Liga Ti-13Nb-13Zr (Figura 71, Figura 77). Pela análise por MEV e EDS, foram padronizadas as identificações das regiões referentes ao implante e ao osso. Os implantes de Ticp identificados no EDS pelo elemento $\mathrm{Ti}$ apresentam 99\% em massa, o mesmo ocorreu nos implantes de Liga Ti-13Nb-13Zr, identificados pelos elementos $\mathrm{Ti}, \mathrm{Nb}$ e $\mathrm{Zr}$. O valor de $1 \%$ apresentado pelos elementos Ca e $\mathrm{P}$, refere-se ao deslocamento de partículas durante a etapa de lixamento dos corte histológicos.

$\mathrm{Na}$ avaliação das amostras do grupo de porosos, para as duas formulações, Ticp e Liga Ti-13Nb-13Zr, foi possível observar a osteointegração pelo crescimento de tecido ósseo mineralizado no interior do implante, caracterizando o aspecto osteocondutivo dos implantes de Ticp (Figura 72 à Figura 76) e Liga Ti-13Nb-13Zr (Figura 78 à Figura 82). Houve o crescimento celular que ocorreu na direção do centro do implante ${ }^{21}$, para a medular óssea, como observado na Figura 76F. A identificação das fases de crescimento ósseo pela técnica de fluorescência foi avaliada conforme a presença de marcadores fluorescentes no interior dos implantes. $\mathrm{Na}$ análise de fluorescência dos implantes porosos estão representadas em uma das fotografias o osso envolvendo o implante e na outra o osso crescendo nos poros do interior do implante, figuras E e F (Figura 72 à Figura 82). Essas imagens foram obtidas em separado pois o tempo de exposição de 
cada marcador com seu respectivo filtro, é diferente, devido à quantidade de marcador presente no osso, intensidade do fluoróforo e interferências ao redor da estrutura.

A identificação das fases de crescimento ósseo pela técnica de fluorescência foi complexa devido à sobreposição dos marcadores fluorescentes. Quando ocorrem sobreposições, as cores se somam. A soma de cores segue o processo de adição da luz, onde o verde com o vermelho resulta no amarelo, verde com azul, resulta no ciano, vermelho com azul resulta no magenta e a soma das três cores primárias que compõe o sistema RGB (vermelho, verde e azul) resulta na cor branca. Assim com base na coloração de cada marcador pode-se inferir quando cada um se sobrepõe ao outro.

A tetraciclina, representada pela cor azul nas micrografias de fluorescência, e também pelas cores magenta (em combinação com a alizarina) e ciano (em combinação com a calceína), teve maior expressividade nos implantes mais porosos, embora também esteja presente nos implantes menos porosos. Isso pode ser explicado pelo fato de os implantes mais porosos permitirem maior fluxo de células no seu interior, evidenciando que esse afluxo maior de células e tecido reparativo permite uma maturação óssea mais rápida (Figura $78 \mathrm{~F}$ à Figura $82 \mathrm{~F}$ ). A alizarina, representada pela cor vermelha nas micrografias de fluorescência, e também pela cor magenta (em combinação com a tetraciclina) e amarela (em combinação com a calceína) é o marcador menos expressivo dos três utilizados. Embora esteja presente em todas as amostras, marcou difusamente no tecido em região de sobreposição de marcadores, mostrando que a maturação e deposição óssea é um processo constante. A calceína, representada pela cor verde nas micrografias de fluorescência, e também pela cor amarela (em combinação com a alizarina) e ciano (em combinação com a tetraciclina) é o marcador que apresentou maior marcação no interior da maioria dos implantes. Isso significa que a maturação do tecido ósseo no interior dos implantes porosos ocorreu durante todo o tempo avaliado e em maior expressão no terço final da experimentação. Isso mostra que os materiais porosos induziram uma deposição óssea contínua no período de tempo avaliado, sendo necessário estudos de duração mais longa para mostrar até quando a deposição óssea é estimulada pelos poros (Figura 71F à Figura $82 \mathrm{~F}$ ), em todas as imagens a presença da cor branca indica a deposição dos três marcadores naquela área e mostra que o processo de maturação e deposição óssea perdurou todo o período da experimentação.

Pela análise de MEV e EDS, foram padronizadas as identificações das regiões referentes ao implante e ao osso (Figura 71B à Figura 82B). Os implantes porosos de Ticp identificados no EDS pelo elemento Ti apresentam de 90 a $96 \%$ em massa, e de 4 a $10 \%$ de osso. Nos implantes de Liga Ti-13Nb-13Zr identificados pelos elementos $\mathrm{Ti}, \mathrm{Nb}$ e 
$\mathrm{Zr}$, apresentam 70 a $77 \%$ em massa e 13 a $33 \%$ de osso. Apesar do valor de quantidade de osso ser bem menor que a quantidade de implante nas micrografias, vale salientar que o EDS (apresentado pelos elementos Ca e P) identifica apenas a matriz óssea mineralizada. O espaço não identificado pelo EDS, pode se referir a parte orgânica do osso, composto por osteoclastos, osteoblastos, vasos e matriz óssea orgânica. A quantificação dessa regiões, osso, poro e implante, foi realizada por análise de imagem das micrografias do interior do implante (Figura 71B à Figura 82B).

Nas amostras com elevada porosidade foi observada a migração do tecido ósseo no interior dos poros dos implantes, fato que confirma a característica osteocondutiva dos materiais baseados em titânio. Diferente dos implantes densos, nos implantes porosos foi observado uma menor osteocondução pela superfície, mas um maior crescimento no interior dos implantes (Figura 72A à Figura 76A, Figura 78A à Figura 82A). A presença de macroporosidades acima de $400 \mu \mathrm{m}$ não favoreceu o preenchimento do tecido ósseo no interior dos poros, apenas algumas regiões na borda dos macroporos apresentaram crescimento ósseo (Figura 73A, Figura 75A, Figura 81A ). Embora o tamanho de poro mínimo que permite o crescimento ósseo seja pequeno, em torno de $10 \mu \mathrm{m}$ a $20 \mu \mathrm{m}$, esse tamanho não permite a propagação da invasão tecidual por todo o implante (Figura $74 \mathrm{E}$, Figura 75E), indicando que apesar do implante ser osteocundutivo, o tamanho de poro é um fator arquitetural determinante para o crescimento ósseo em todo o seu potencial. Isto foi observado nos implantes porosos com poros em torno de $100 \mu \mathrm{m}$, sendo que ocorreu não apenas crescimento ósseo, como também, invasão em todo o implante, em alguns casos atravessando todo o implante com tecido ósseo novo Figura 79F. Assim, pode-se definir que a osteocondutividade e interconectividade dos poros não são os únicos fatores que irão determinar o crescimento ósseo através dos poros. $O$ tamanho do poro também é determinante, sendo necessário não apenas para nutrição e manutenção das células ósseas, mas também para estimular o crescimento ósseo contínuo por toda a estrutura, dando um suporte em forma de arcabouço para seu crescimento sustentado.

A utilização de albumina como aditivo pela técnica de "space-holder" é inédita, com isso se buscou agregar além do tamanho e formato de poro favorável a impressão molecular da proteína no material, devido sua função no reconhecimento biológico, já que é a proteína mais abundante no sangue e a principal proteína a ser adsorvida por biomateriais. Embora seja necessária investigação mais aprofundada desse padrão molecular superficial, os resultados de crescimento ósseo no interior dos implantes obtidos com adição de albumina foram os mais proeminentes para os dois materiais (Ticp 
e Liga) (Figura 76F, Figura 82F). No qual dos implantes de Ticp foi o único a permitir o crescimento de osso cruzando o interior do implante transversalmente, formando uma ponte entre as duas corticais. Nos implantes de Liga com adição de albumina, foi observado a maior expressão dos marcadores fluorescentes, com um resultado de 3+ para os três marcadores (Tabela 6).

As ferramentas utilizadas para a análise histológica deste estudo permitiram a identificação do tecido ósseo formado de uma maneira simplificada. Por MEV foi possível observar a interação entre o tecido e o implante, a identificação celular foi observada pela morfologia, e a diferenciação entre tecido ósseo e implante foi caracterizado por EDS, que qualificou e quantificou os elementos. A análise de fluorescência complementou o estudo identificando os períodos de maturação do tecido ósseo no interior dos implantes. 

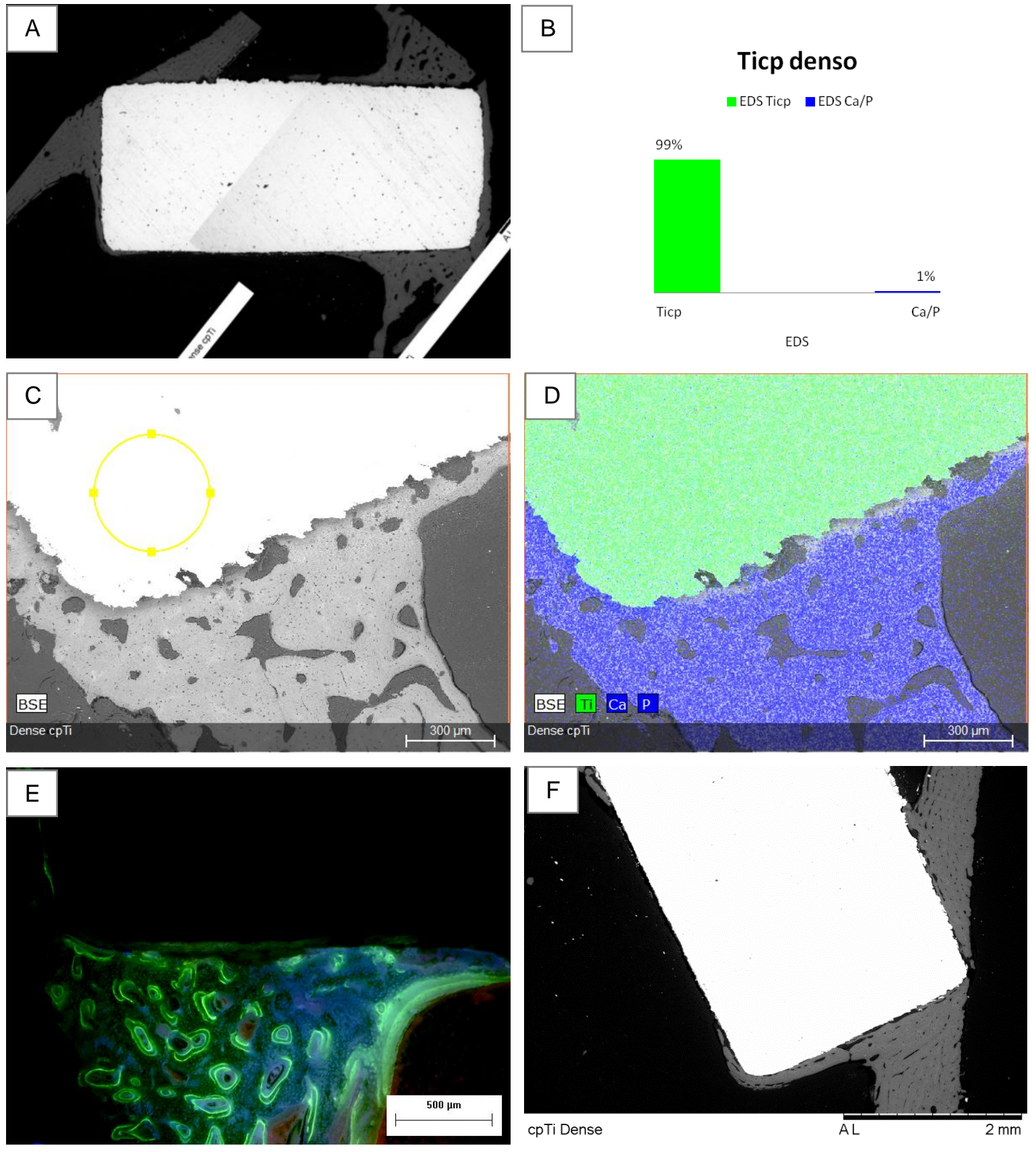

Figura 71. Implante de Ticp denso: A) MEV do corte histológico (montagem), observação da interação do osso e implante; B) Gráfico quantitativo relativo a figura C; C) MEV do corte histológico representando a interface osso e implante; D) EDS do corte histológico da imagem representada em C; E) Microscopia de fluorescência dos marcadores ósseos, interface osso e implante; F) MEV do corte histológico, observação da osteocondução pela superfície do implante. 


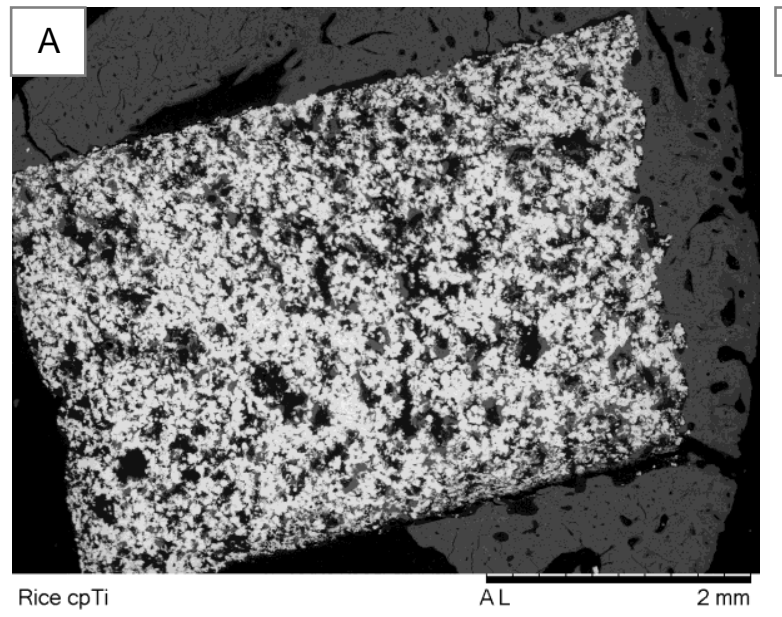

B
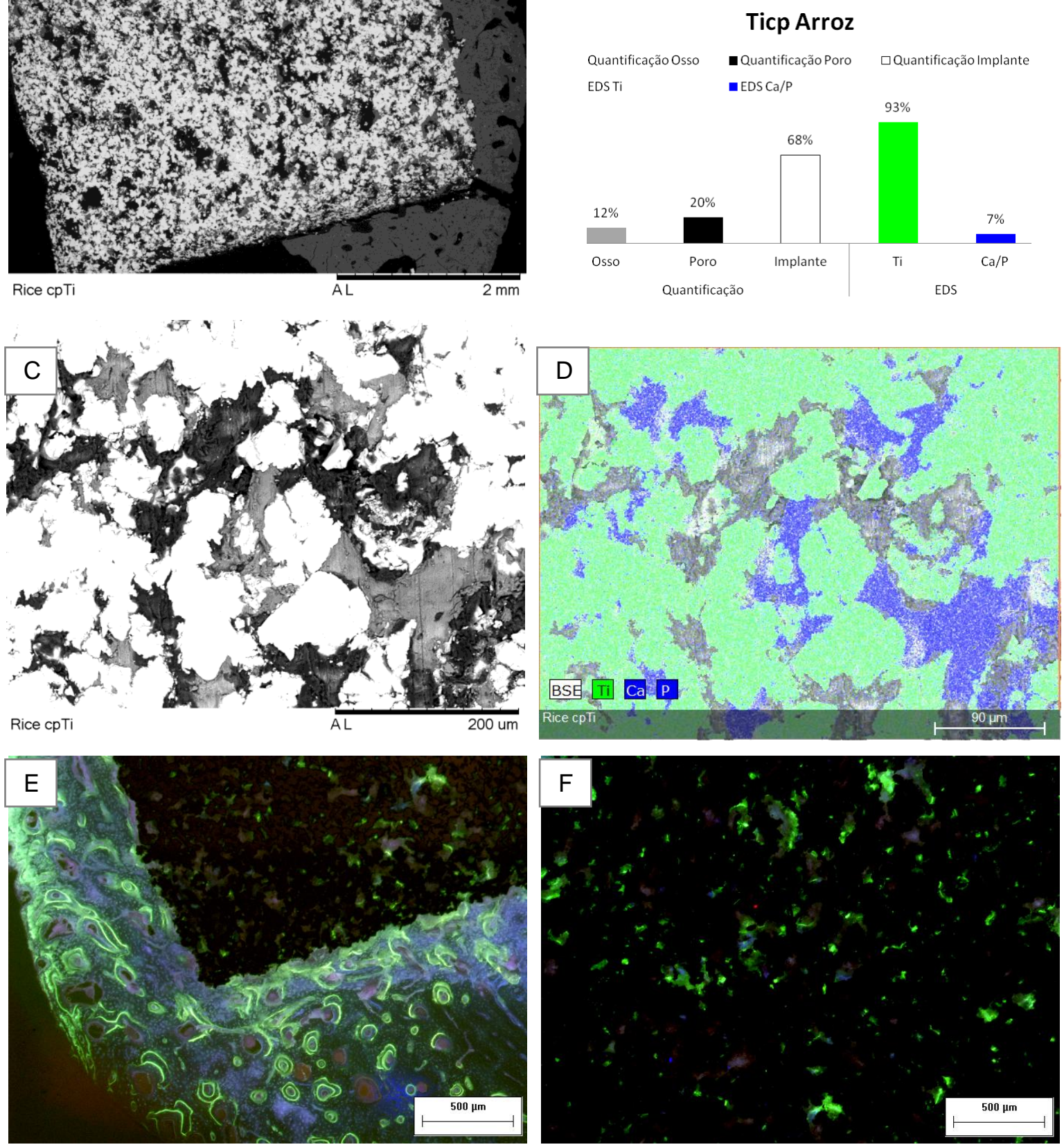

Figura 72. Implante de Ticp obtida pela adição de amido de arroz: A) MEV do corte histológico, observação da interação do osso e implante; B) Gráfico quantitativo relativo as figuras $\mathrm{C}$ e D; C) MEV do corte histológico representando áreas de poro, osso e implante; D) EDS do corte histológico da imagem representada em C; E) Microscopia de fluorescência dos marcadores ósseos, interface osso e implante; F) Microscopia de fluorescência dos marcadores ósseos, interior do implante. 


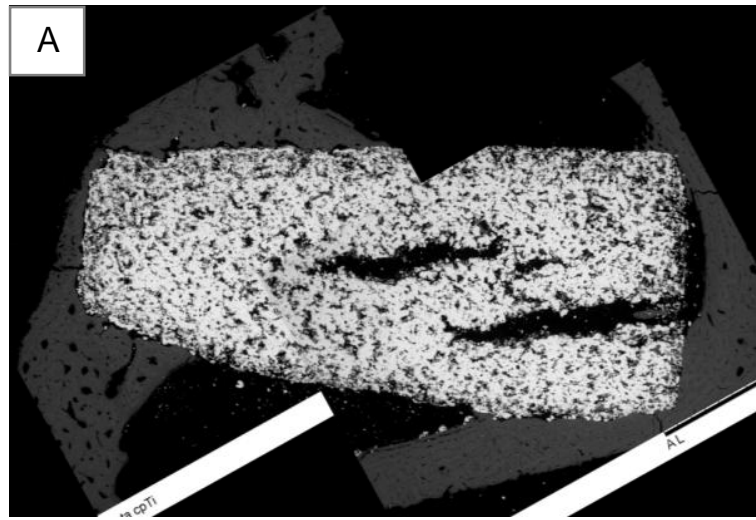

B
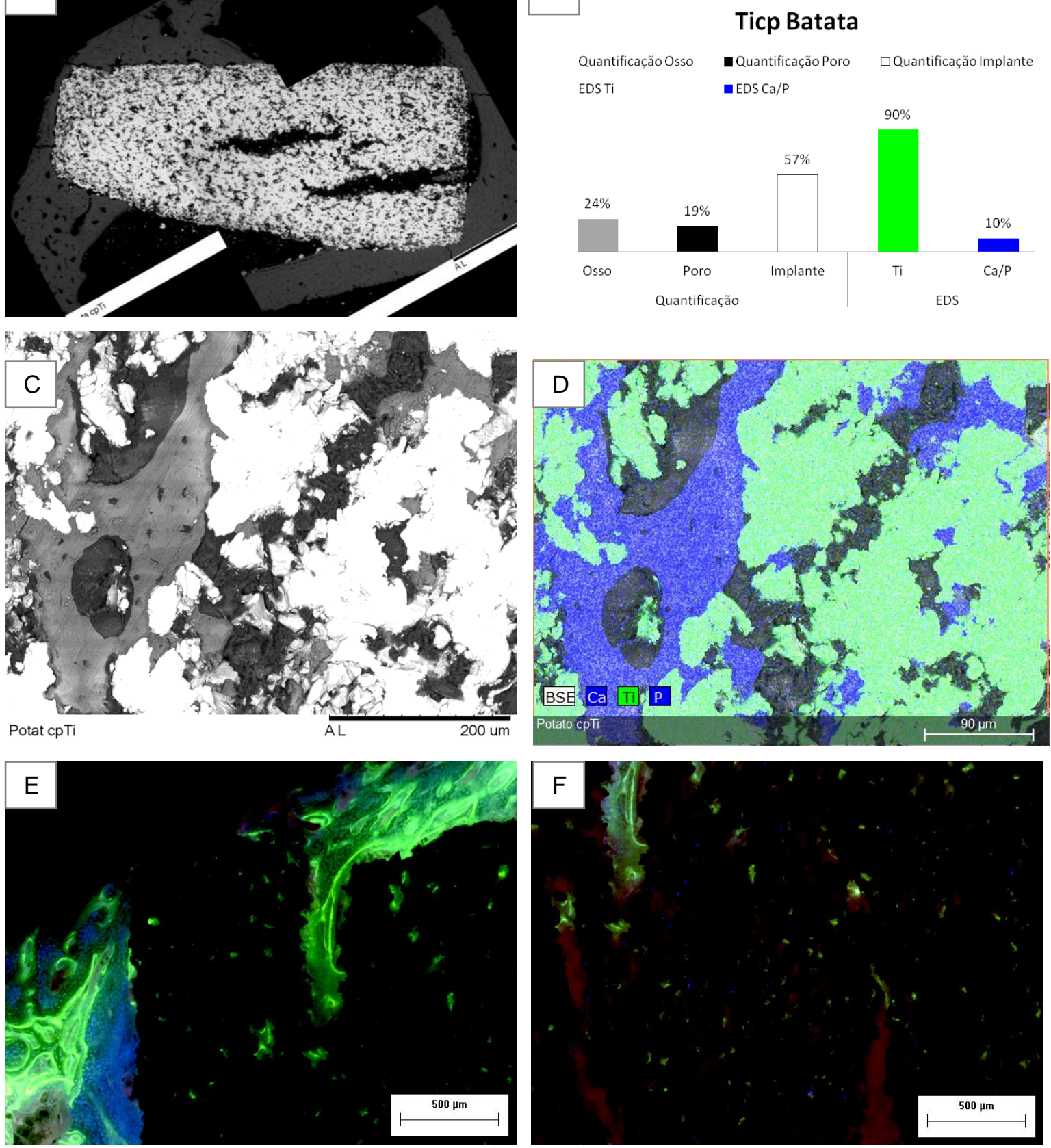

Figura 73. Implante de Ticp obtida pela adição de amido de batata: A) MEV do corte histológico (montagem), observação da interação do osso e implante; B) Gráfico quantitativo relativo as figuras $\mathrm{C}$ e $\mathrm{D} ; \mathrm{C}) \mathrm{MEV}$ do corte histológico representando áreas de poro, osso e implante; D) EDS do corte histológico da imagem representada em C; E) Microscopia de fluorescência dos marcadores ósseos, interface osso e implante; F) Microscopia de fluorescência dos marcadores ósseos, interior do implante. 

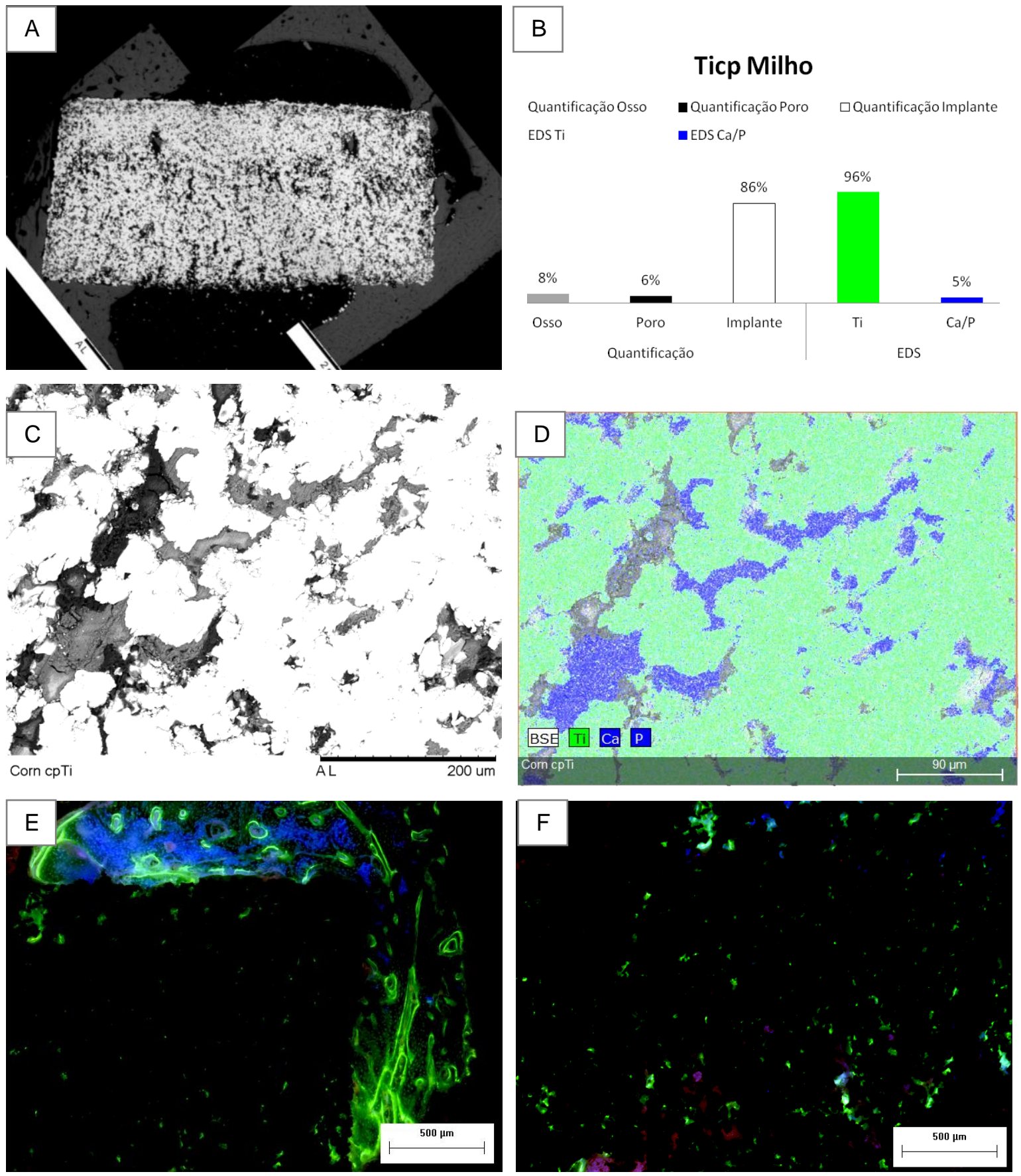

Figura 74. Implante de Ticp obtida pela adição de amido de milho: A) MEV do corte histológico (montagem), observação da interação do osso e implante; B) Gráfico quantitativo relativo as figuras $\mathrm{C}$ e $\mathrm{D} ; \mathrm{C}) \mathrm{MEV}$ do corte histológico representando áreas de poro, osso e implante; D) EDS do corte histológico da imagem representada em C; E) Microscopia de fluorescência dos marcadores ósseos, interface osso e implante; F) Microscopia de fluorescência dos marcadores ósseos, interior do implante. 

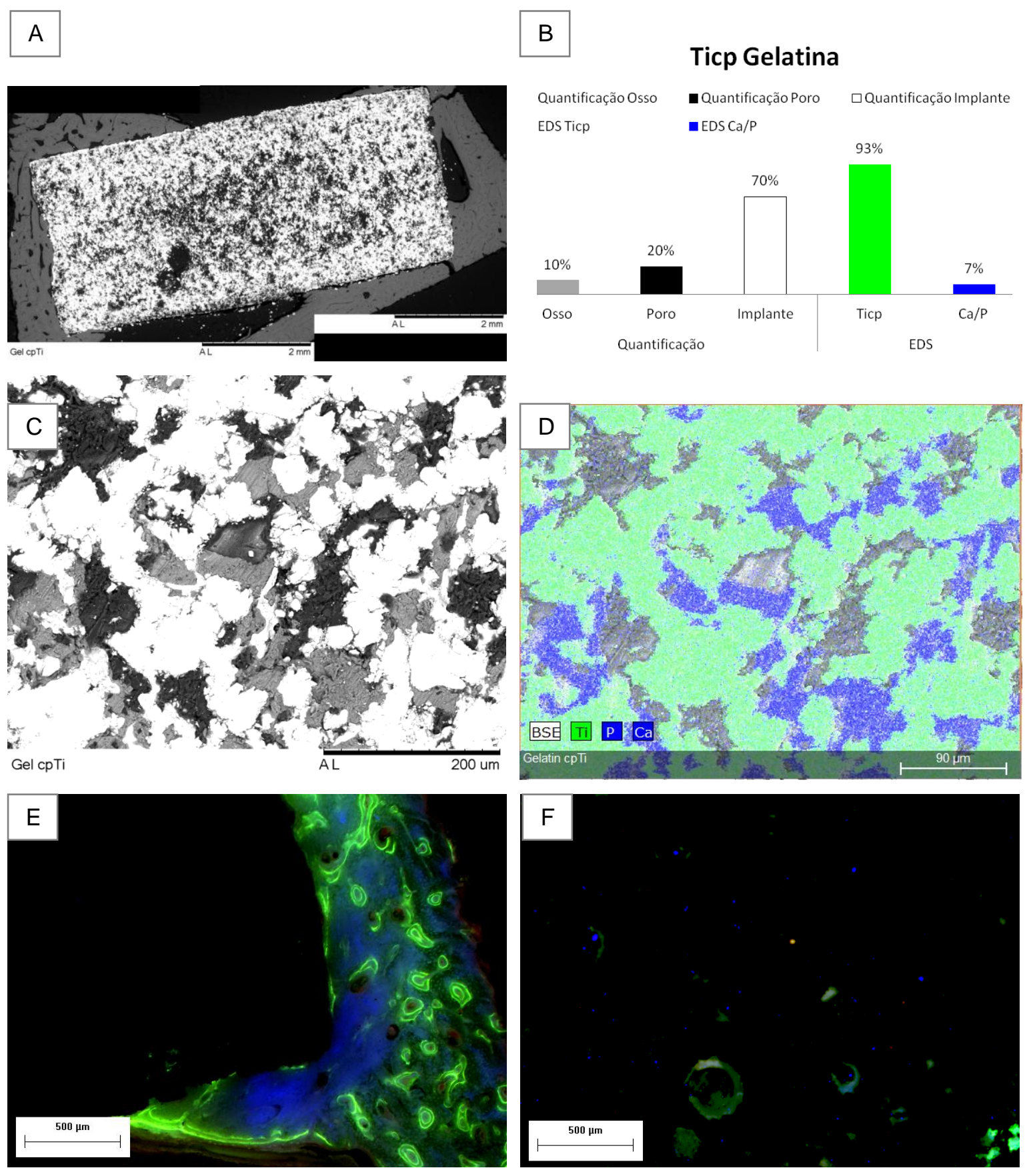

Figura 75. Implante de Ticp obtida pela adição de gelatina: A) MEV do corte histológico (montagem), observação da interação do osso e implante; B) Gráfico quantitativo relativo as figuras C e D; C) MEV do corte histológico representando áreas de poro, osso e implante; D) EDS do corte histológico da imagem representada em C; E) Microscopia de fluorescência dos marcadores ósseos, interface osso e implante; F) Microscopia de fluorescência dos marcadores ósseos, interior do implante. 


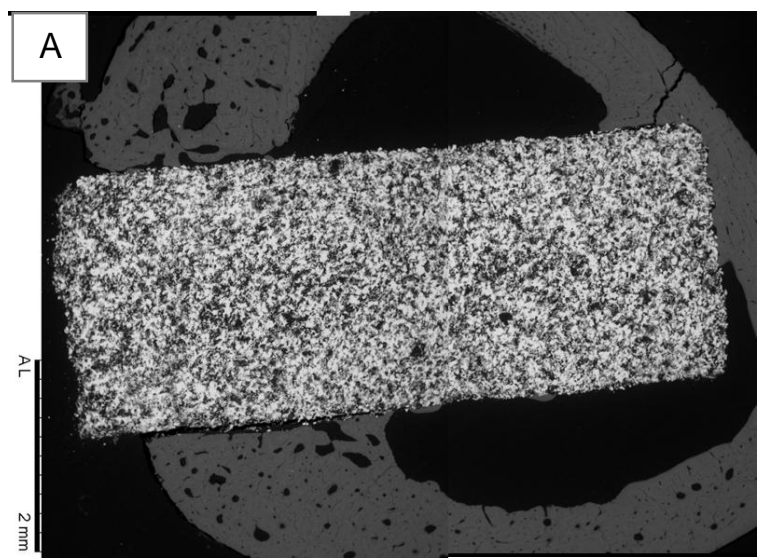

B
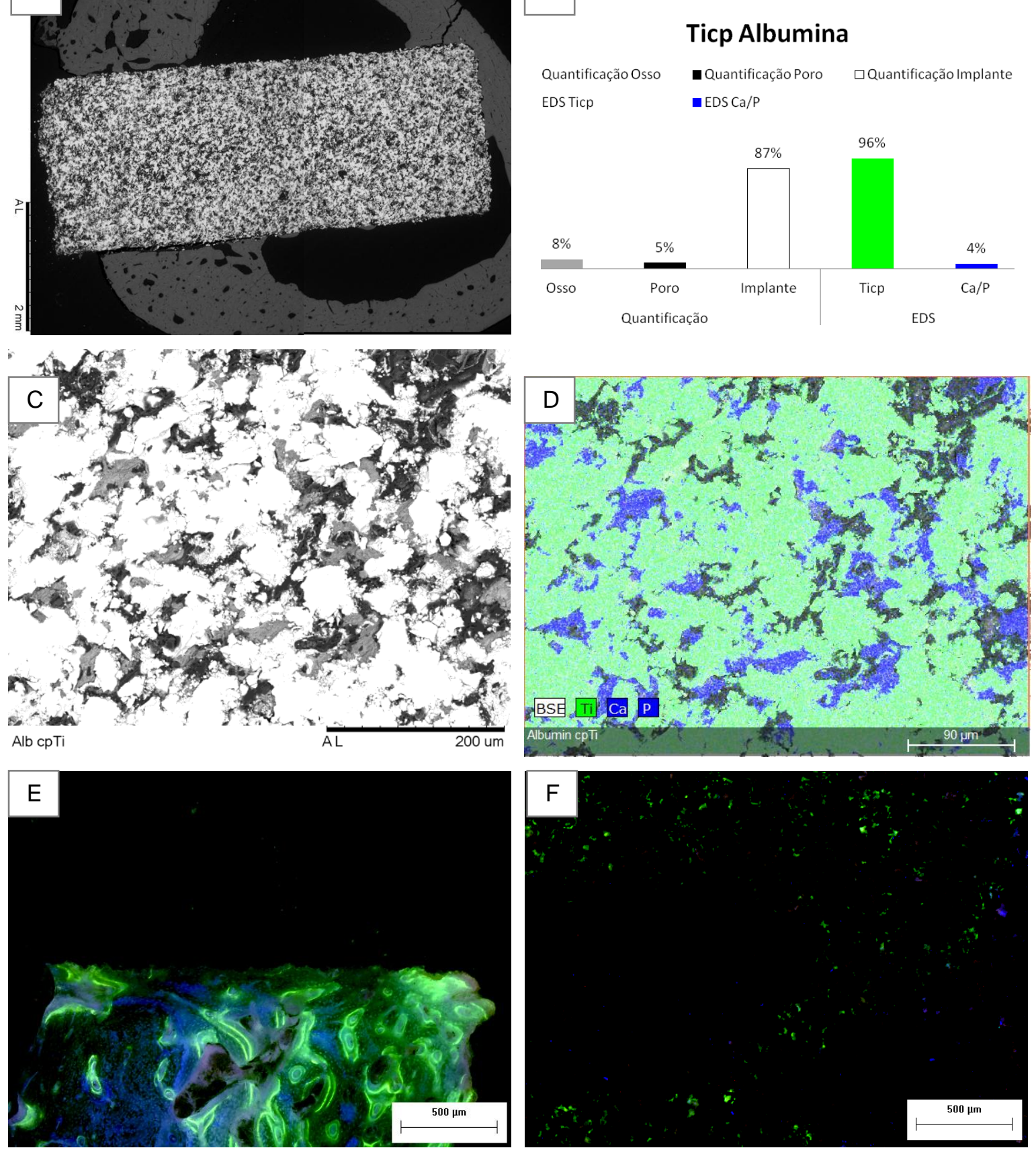

Figura 76. Implante de Ticp obtida pela adição de albumina: A) MEV do corte histológico (montagem), observação da interação do osso e implante; B) Gráfico quantitativo relativo as figuras $\mathrm{C}$ e D; C) MEV do corte histológico representando áreas de poro, osso e implante; D) EDS do corte histológico da imagem representada em C; E) Microscopia de fluorescência dos marcadores ósseos, interface osso e implante; F) Microscopia de fluorescência dos marcadores ósseos, interior do implante. 


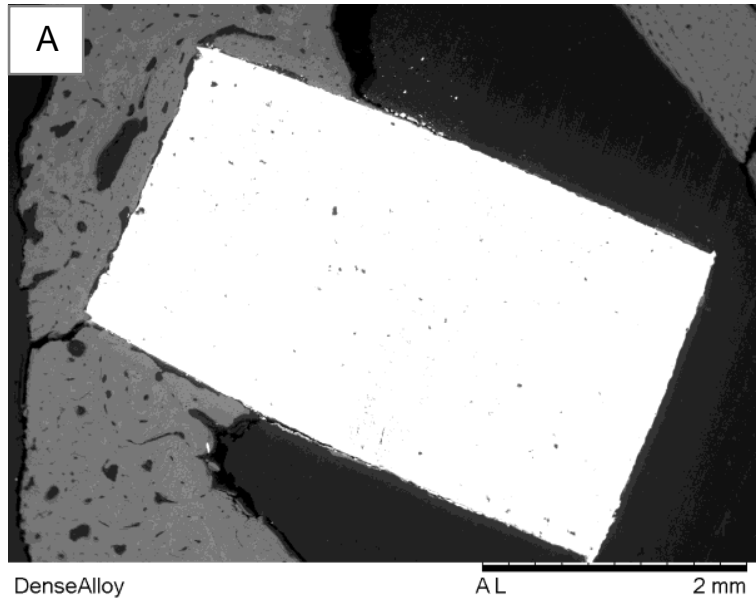

\section{B}

\section{Liga denso}

EDSTi13Nb13Zr $\quad$ EDSCa/P

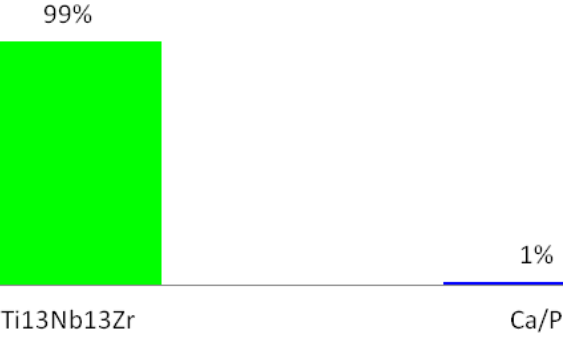

EDS
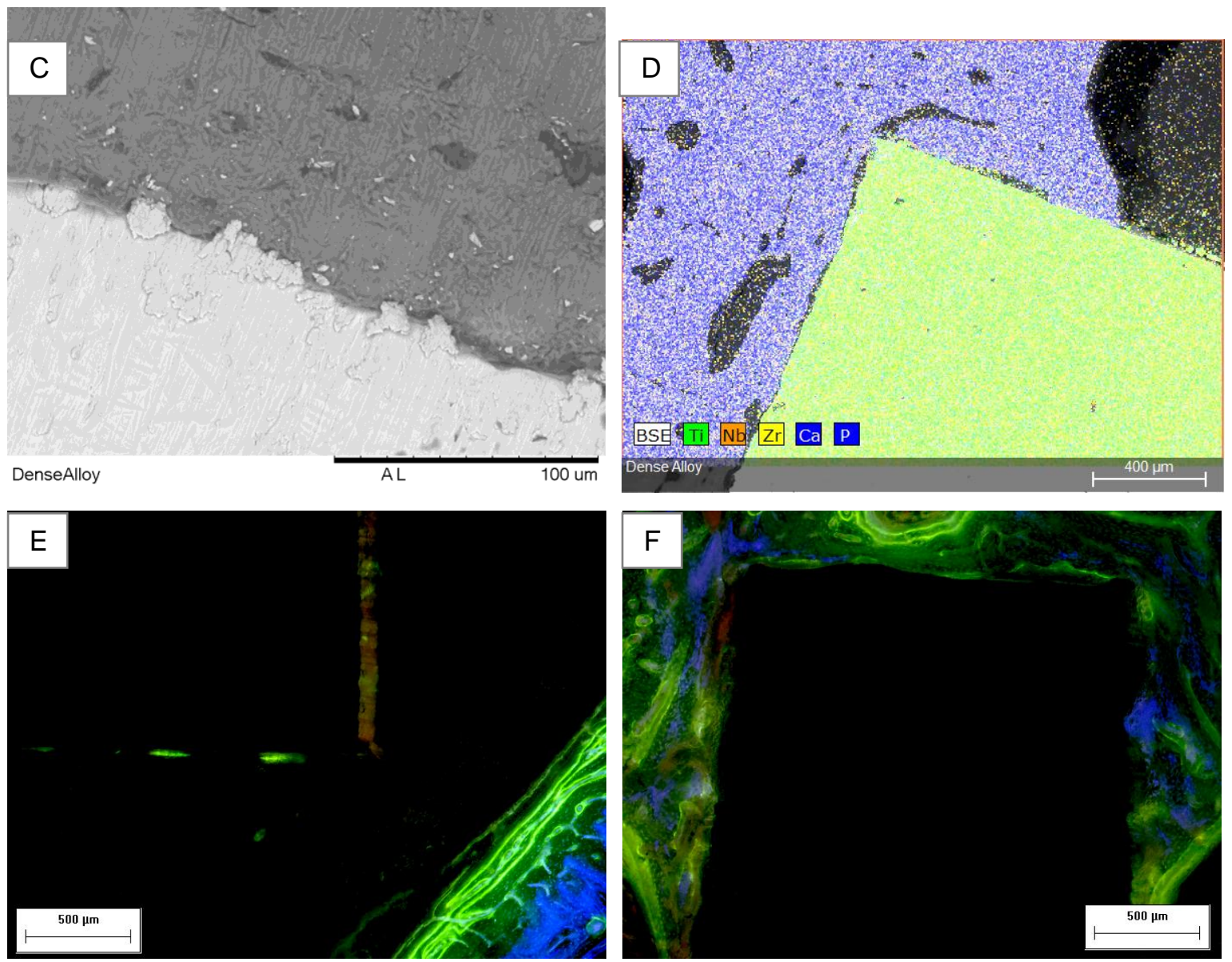

Figura 77. Implante de Liga denso: A) MEV do corte histológico, observação da interação do osso e implante; B) Gráfico quantitativo relativo a figuras C; C) MEV do corte histológico representando áreas de interface osso e implante; D) EDS do corte histológico; E) Microscopia de fluorescência dos marcadores ósseos, interface osso e implante; F) Microscopia de fluorescência dos marcadores ósseos, interior do implante. 

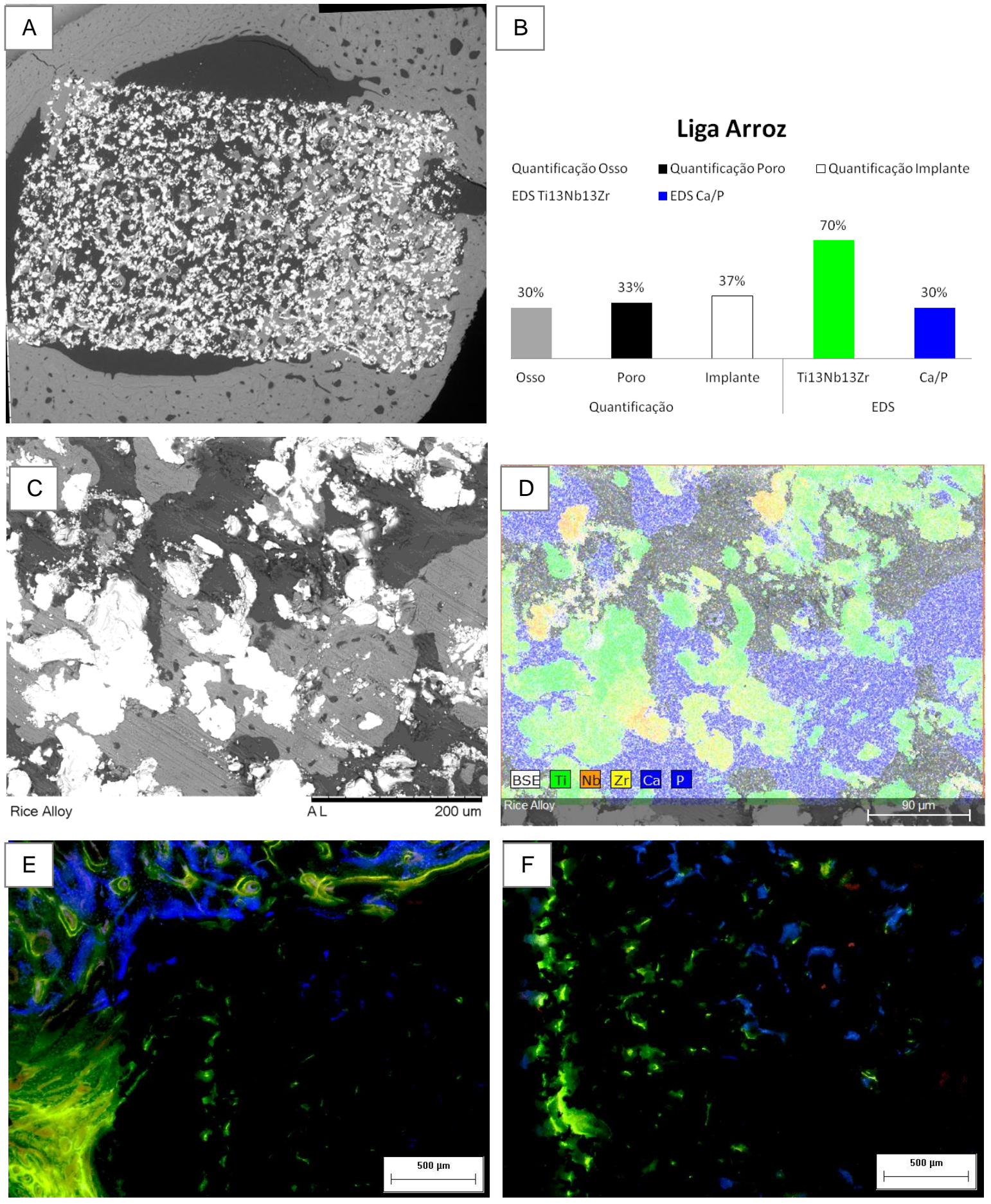

Figura 78. Implante de Liga obtida pela adição de amido de arroz: A) MEV do corte histológico (montagem), observação da interação do osso e implante; B) Gráfico quantitativo relativo as figuras $\mathrm{C}$ e $\mathrm{D} ; \mathrm{C}) \mathrm{MEV}$ do corte histológico representando áreas de poro, osso e implante; D) EDS do corte histológico da imagem representada em C; E) Microscopia de fluorescência dos marcadores ósseos, interface osso e implante; F) Microscopia de fluorescência dos marcadores ósseos, interior do implante. 

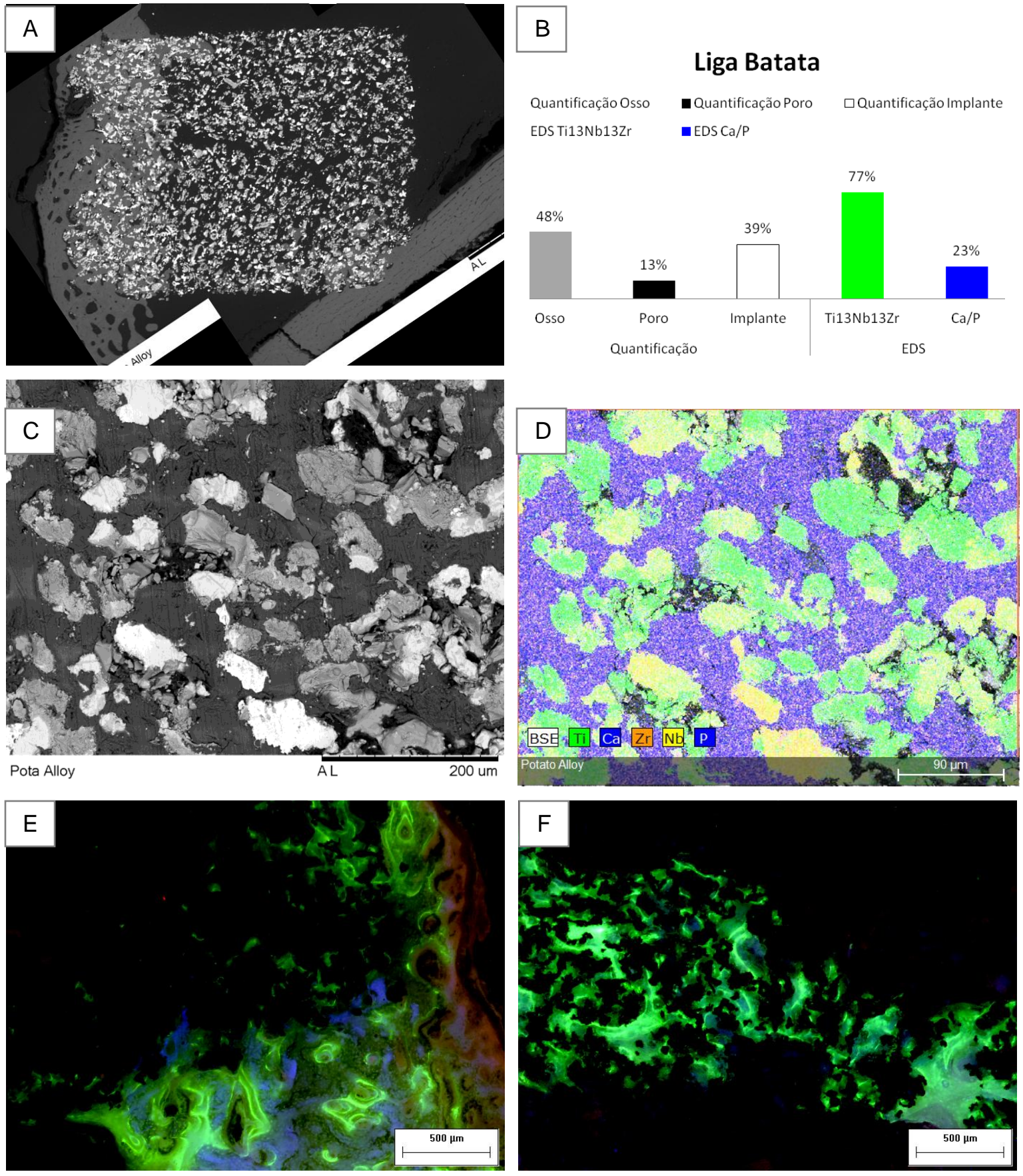

Figura 79. Implante de Liga obtida pela adição de amido de batata: A) MEV do corte histológico (montagem), observação da interação do osso e implante; B) Gráfico quantitativo relativo as figuras $\mathrm{C}$ e $\mathrm{D} ; \mathrm{C}) \mathrm{MEV}$ do corte histológico representando áreas de poro, osso e implante; D) EDS do corte histológico da imagem representada em C; E) Microscopia de fluorescência dos marcadores ósseos, interface osso e implante; F) Microscopia de fluorescência dos marcadores ósseos, interior do implante. 

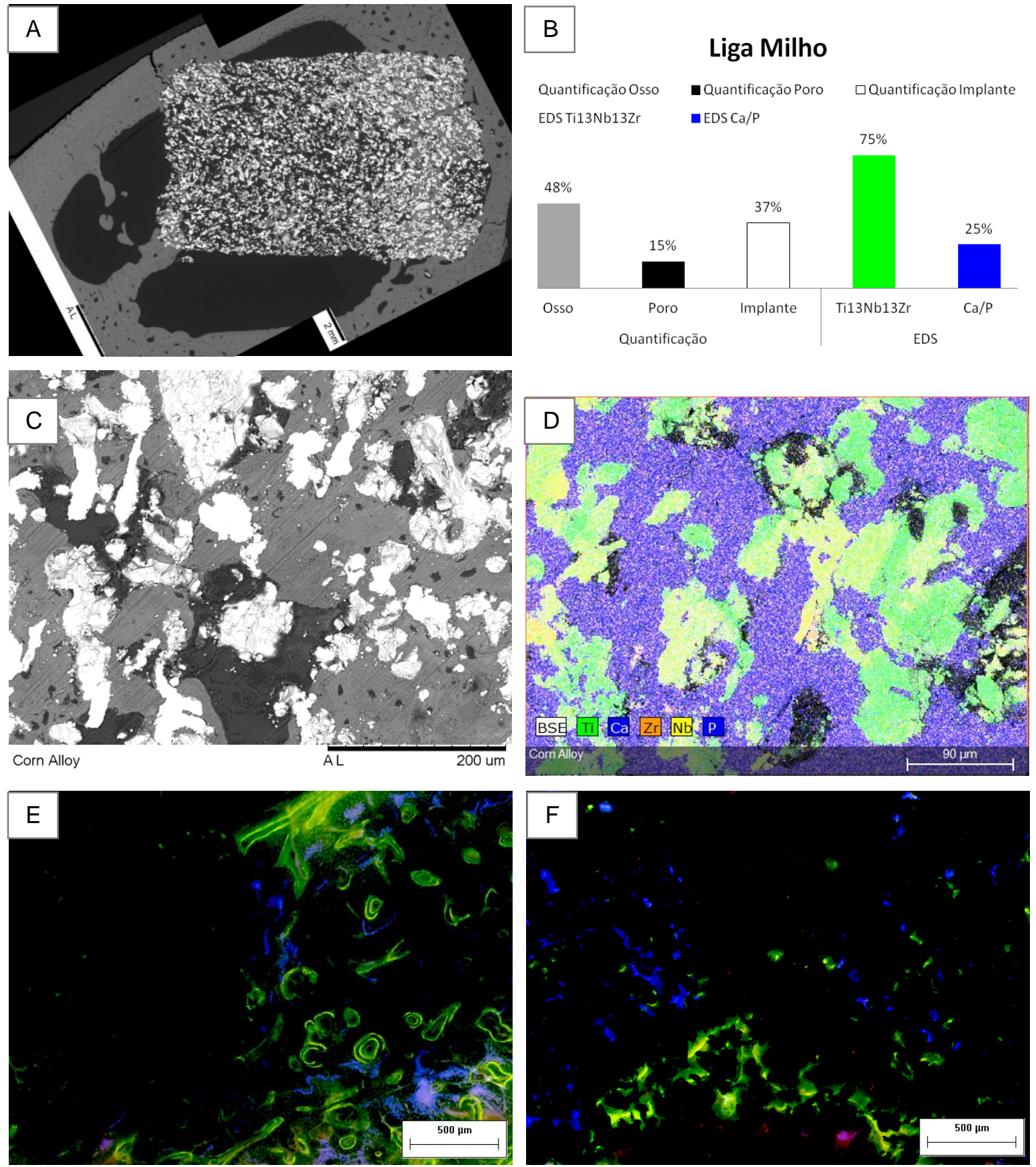

Figura 80. Implante de Liga obtida pela adição de amido de milho: A) MEV do corte histológico (montagem), observação da interação do osso e implante; B) Gráfico quantitativo relativo as figuras $\mathrm{C}$ e $\mathrm{D} ; \mathrm{C}) \mathrm{MEV}$ do corte histológico representando áreas de poro, osso e implante; D) EDS do corte histológico da imagem representada em C; E) Microscopia de fluorescência dos marcadores ósseos, interface osso e implante; F) Microscopia de fluorescência dos marcadores ósseos, interior do implante. 


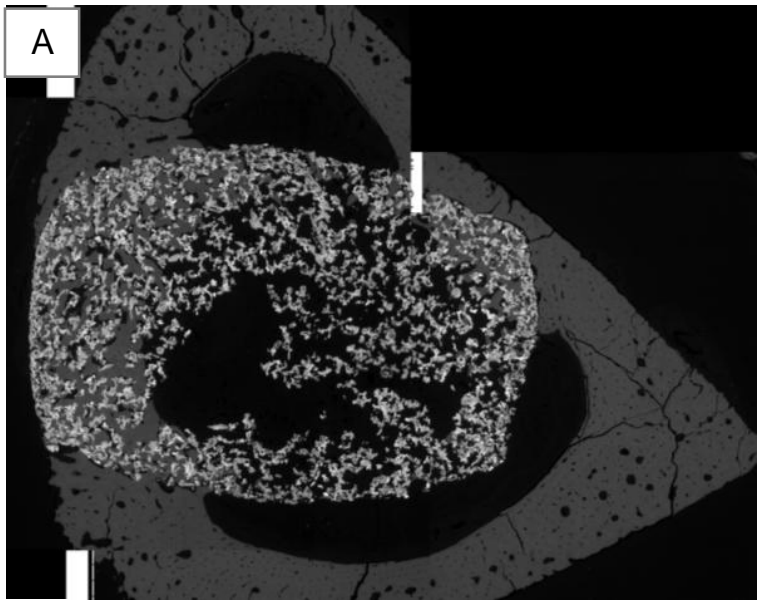

B
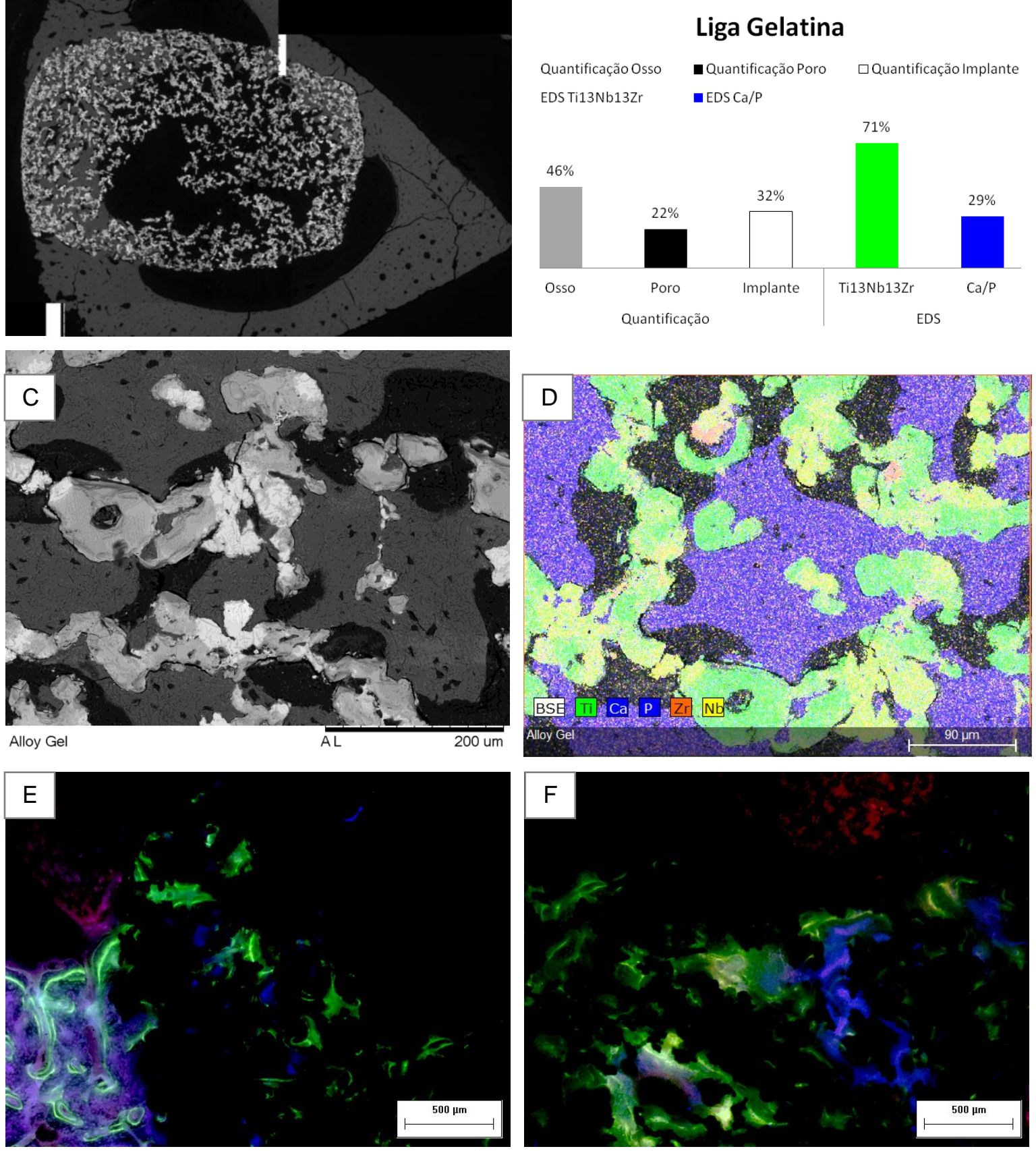

Figura 81. Implante de Liga obtida pela adição de gelatina: A) MEV do corte histológico (montagem), observação da interação do osso e implante; B) Gráfico quantitativo relativo as figuras $\mathrm{C}$ e D; C) MEV do corte histológico representando áreas de poro, osso e implante; D) EDS do corte histológico da imagem representada em C; E) Microscopia de fluorescência dos marcadores ósseos, interface osso e implante; F) Microscopia de fluorescência dos marcadores ósseos, interior do implante. 

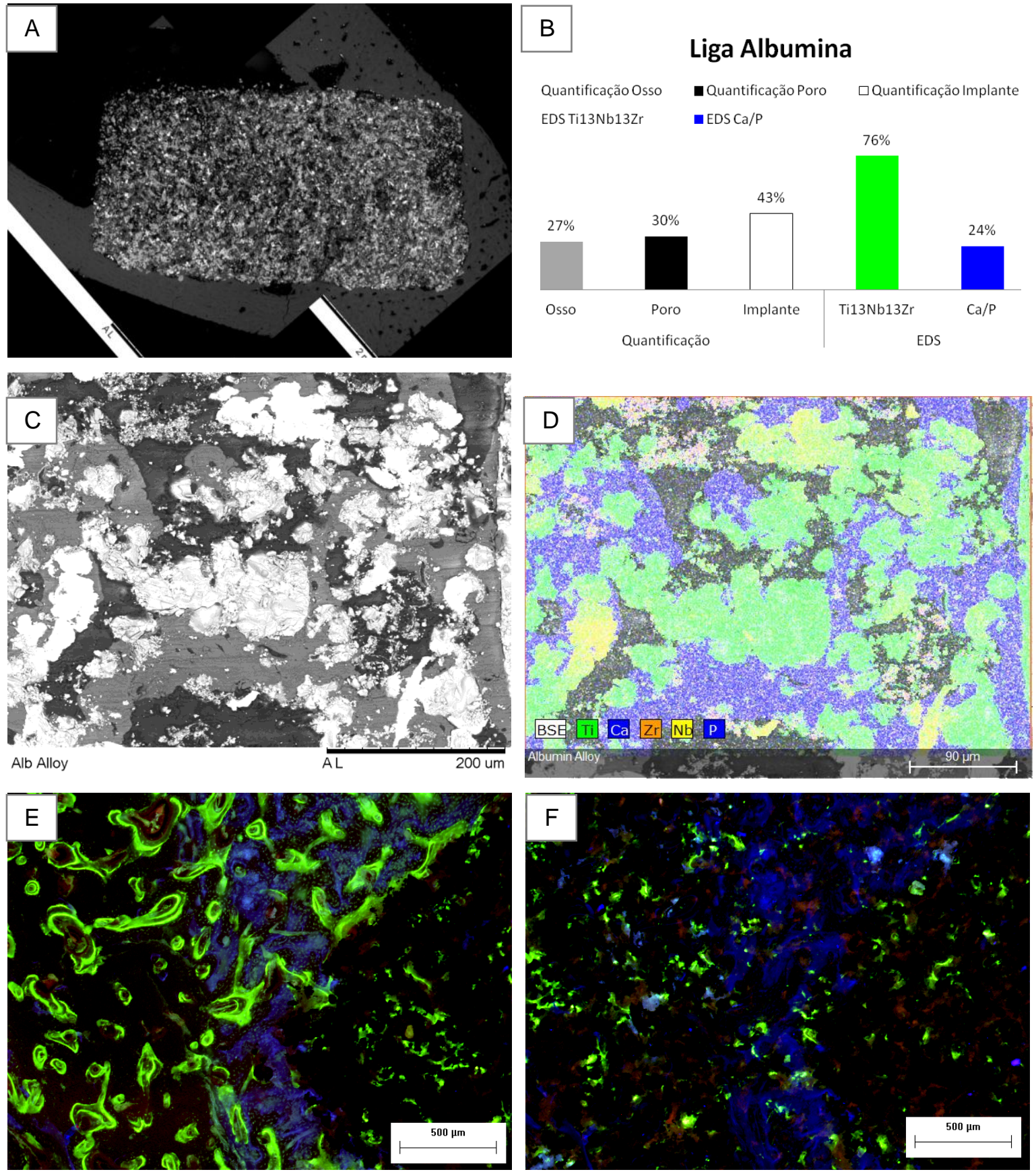

Figura 82. Implante de Liga obtida pela adição de albumina: A) MEV do corte histológico (montagem), observação da interação do osso e implante; B) Gráfico quantitativo relativo as figuras C e D; C) MEV do corte histológico representando áreas de poro, osso e implante; D) EDS do corte histológico da imagem representada em C; E) Microscopia de fluorescência dos marcadores ósseos, interface osso e implante; F) Microscopia de fluorescência dos marcadores ósseos, interior do implante. 
Conclusões

Finalizando este estudo, as principais conclusões estão apresentadas neste capítulo. 


\section{CONCLUSÕES}

A partir do processo de metalurgia do pó com adição de polímeros naturais foi possível obter materiais com mais que $40 \%$ de porosidade. As metodologias foram aprimoradas e aplicadas de acordo com o polímero natural (amido de arroz, amido de batata, amido de milho, gelatina e albumina) e metais (Ticp e liga Ti-13Nb-13Zr) utilizados.

- Dos processos desenvolvidos, foram obtidos cinco materiais com porosidades diferenciadas, boa homogeneidade estrutural, grau de porosidade adequado (entre $40 \%$ e $60 \%$ ), distribuição e tamanho dos poros conforme o polímero natural formador.

- O ensaio in vitro mostrou que as metodologias e os processos de obtenção dos materiais são compatíveis para utilização em organismos vivos, pois não apresentam citotoxicidade.

- Pelo ensaio in vivo, todos os implantes produzidos e descritos, osteointegraram e osteoconduziram o osso. A osteocondução nos implantes usinados percorreu a superfície do implante, enquanto que nos implantes porosos, a osteocondução ocorreu no interior do implante.

- Os implantes com melhores resultados foram os que apresentam porosidade homogênea, independente do tamanho médio de poros.

- Poros acima de $400 \mu \mathrm{m}$ de diâmetro não favorecem o crescimento ósseo no seu interior no período estudado, e poros com diâmetro menores $100 \mu \mathrm{m}$ permitem o crescimento de tecido ósseo, porém dificultam a ação da invasão tecidual no interior do implante. Entre 100 e $200 \mu \mathrm{m}$ foram obtidos os melhores resultados de crescimento ósseo.

- A análise de cortes histológicos por MEV e EDS, permitiu quantificar e avaliar o crescimento ósseo no interior dos implantes.

- Com a análise por fluorescência foi possível observar as áreas de crescimento ósseo em relação ao tempo de implantação e suas estratificações no interior dos implantes.

- Combinando os valores de porosidade e a quantidade de marcação do fluoróforo tetraciclina foi observado que quanto maior a porosidade mais rápida é a deposição de matriz óssea mineralizada após implantação. 
- Após o período de experimentação in vivo a remodelação ainda estava ativa e ocorrendo, com deposição de nova matriz óssea mineralizada evidenciada pela fluorescência emitida pelo marcação do fluoróforo calceína.

Assim, os materiais porosos de titânio e da liga Ti-13Nb-13Zr produzidos com os polímeros naturais (amido de arroz, amido de batata, amido de milho, gelatina e albumina), que apresentam porosidade homogênea com tamanho médio de poros entre 100 e $200 \mu \mathrm{m}$, permitiram a nutrição e manutenção necessárias para a sobrevivência das células, comprovando a osteointegração e osteocondução dos implantes desenvolvidos. 


\section{ANEXOS}

Anexo I - Aprovação do comitê de ética em pesquisa para realização dos testes in vivo.

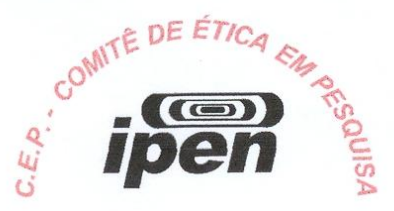

Parecer - Projeto $N^{\circ}$ 69/10 - CEUA-IPEN/SP

Com base nos pareceres apresentados pelos relatores, o protocolo de pesquisa "AVALIAÇÃO IN VITRO E IN VIVO DE TITÂNIO E SUAS LIGAS" de responsabilidade do pesquisador ANA HELENA DE ALMEIDA BRESSIANI foi considerado APROVADO.

Tendo em vista a legislação vigente, devem ser encaminhados, a este Comitê, relatórios anuais (parciais ou finais, dependendo da duração do projeto) referentes ao andamento da pesquisa. Após o término da pesquisa, uma cópia do trabalho deve ser encaminhada a este CEUA

São Paulo, 29 de novembro de 2010

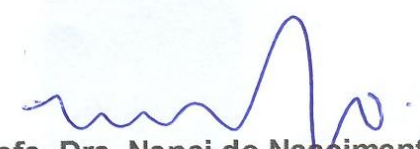

Profa. Dra. Nanci do Nascimento

Coordenadora do CEUA-IPEN 
Anexo II - Protocolo de embutimento para Resina Technovit 9100 NEW

1) Amostras fixadas em formol (10\%) por 30 dias.

2) Desidratação:

a. Álcool 50\% - 3 horas e 30 min

b. Álcool $95 \%$ - 3 horas e $30 \mathrm{~min}$

c. Álcool $95 \%$ - 3 horas e $30 \mathrm{~min}$

d. Álcool 95\% - 8 horas e 30 min

e. Álcool $100 \%$ - 3 horas e 30 min

f. Álcool 100\% - 3 horas e 30 min

g. Álcool 100\% - 3 horas e 30 min

h. Álcool $100 \%$ - 8 horas e $30 \mathrm{~min}$

i. Xilol - 3 horas e $30 \mathrm{~min}$

j. Xilol -24 horas

k. Xilol - 24 horas

3) Pré-infiltração:

I. Resina $(50 \%)+$ Xilol $(50 \%)-24$ horas

m. Resina (estabilizada) + Hardener -1 - 24 horas

n. Resina (desestabilizada) + Hardener $-1-24$ horas em geladeira

o. Solução A - 1 hora em geladeira

1) PMMA

2) Resina desestabilizada

3) Hardener - 1

4) Polimerização:

p. Solução $A(9$ partes $)+$ Solução $B(1$ parte $)-7$ dias em $-8^{\circ} \mathrm{C}$ até $-20^{\circ} \mathrm{C}$ 


\section{REFERÊNCIAS BIBLIOGRÁFICAS}

1 ORÉFICE, R.L.; PEREIRA, M.M.; MANSUR, H.S. Biomateriais - Fundamentos e Aplicações. 1a Ed. Cultura Médica, Rio de Janeiro, 2006.

2 LEMONS, J.E. Biomaterials, Biomechanics, Tissue Healing, and Immediate-Function Dental Implants. J Oral Implantol, vol. 30, n.5, pp. 318-324, 2004.

3 PUELO, D.A.; NANCI, A. Understanding and controlling the bone-implant interface. Biomaterials, vol. 20, n. 23-24, pp. 2311-2321, 1999.

4 RYAN, G.; PANDIT. A.; APATSIDIS, D.P. Fabrication methods of porous metals for use in orthopedic applications. Biomaterials, Review, vol. 27, n. 13, pp. 2651-70, 2006.

5 SPENCER, A.P. Anatomia humana básica. Manole. 2.ed. São Paulo, Brasil, 1991

6 WEINLAENDER, M. Bone growth around dental implants. Dent Clin North Am., vol. 35, n.3, pp. 585-601, 1991.

7 JUNQUEIRA, L.C.; CARNEIRO, J. Histologia básica. Guanabara Koogan. 8.ed. Rio de Janeiro, Brasil, 1995.

8 FRANZ, S.; RAMMELT, S.; SCHARNWEBER, D.; SIMON, J.C. Immune responses to implants - A review of the implications for the design of immunomodulatory biomaterials.

Biomaterials, vol. 32, pp. 6692 - 6709, 2011.

9 LIU, X.; CHU, P.K.; DING, C. Surface modification of titanium, titanium alloys, and related materials for biomedical applications. Mater Sci Eng $\boldsymbol{R}$ Rep, vol. 47, n. 3-4, pp. 49-121, 2004.

10 SHEN, H.; BRINSON, L.C. A numerical invention of porous titanium as orthopedic implant material. Mech Mater, vol.8, pp. 420-430, 2011.

11 HULBERT, S.F.; YOUNG, F.A.; MATHEWS, R.S.; KLAWITTER, J.J.; TALBERT, C.D.; STELLING, F.H. Potential of ceramic materials as permanently implantable skeletal prostheses. J Biomed Mater Res, vol. 4, n. 3, pp. 433-56, 1970.

12 ITÄLA, A.I.; YLANEN, H.O.; EKHOLM, C.; KARLSSON, K.H.; ARO, H.T. Pore diameter of more than 100 micron is not requisite for bone ingrowth in rabbits. $\boldsymbol{J}$ Biomed Mater Res, vol. 58, n. 6, pp. 679-683, 2001.

13 KUJALA, S.; RYHÄNEN, J.; DANILOV, A.; TUUKKANEN, J. Effect of porosity on the osteointegration and bone ingrowth of a weight-bearing nickel-titanium bone graft substitute. Biomaterials, vol. 24, pp. 4691-4697, 2003. 
14 LAPTEV, A.; BRAM, M.; BUCHKKEMER, H.P.; STOVER, D. Study of production route for titanium parts combining very high porosity and complex shape. Powder Metall, vol. 47, pp. 85-92, 2004.

15 LI, J.; LIAO, H.; FARTASH, B.; HERMANSSON, L.; JOHNSSON, T. Surface-dimpled commercially pure titanium implant and bone ingrowth. Biomaterials, vol. 18, pp. 691696, 1997.

16 TAKEMOTO, M.; FUJIBAYASHI, S.; NEO, M.; SUZUKI, J.; KOKUBO, T.; NAKAMURA, T. Mechanical properties and osteoconductivity of porous bioactive titanium. Biomaterials, vol. 26, n. 30, pp. 6014-6023, 2005.

17 GÖTZ, H.E.; MÜLLER, M.; EMMEL, A.; HOLZWARTH, U.; ERBEN, R.G.; STANGL, R. Effect of surface finish on the osseointegration of laser-treated titanium alloy implants. Biomaterials, vol. 25, pp. 4057-4064, 2004.

18 CACHINHO, S.C.P.; CORREIA, R.N. Titanium scaffolds for osteointegration: mechanical, in vitro and corrosion behavior. J Mater Sci: Mater Med, vol. 19, pp.451457, 2008.

19 ANGELO, P.C.; SUBRAMANIAN, R. Powder Metallurgy: Science, Technology and Applications. 2ed., Editora PHI Learning Private Limited, New Delhi, 2008.

20 BOTTINO, M.C.M. Estudo da osteointegração da Liga Ti-13Nb-13Zr obtida por metalurgia do pó com diferentes graus de porosidades. Dissertação de mestrado. Instituto de pesquisas energéticas e nucleares, São Paulo, 127 páginas, 2005.

$21 \mathrm{GOIA}$, T.S. Avaliação in vitro e in vivo de ligas porosas de Ti-13Nb-13Zr obtidas por metalurgia do pó. Dissertação de mestrado. Instituto de pesquisas energéticas e nucleares, São Paulo, 103 páginas, 2008.

22 AGUIKAR MAYA, A.E.; GRANA, D.R.; HAZARABEDIAN, A.; KOKUBO, G.A.; LUPPO, M.I.; VIGNA, G. Zr-Ti- Nb porous alloy for biomedical application. Mat Sci Eng C, vol. 32, pp. 321-329, 2011.

23 SHARMA, M.; GUPTA, G.K.; MODI, O.P.; PRASAD, B.K.; GUPTA, A.K. Titanium foam through powder metallurgy route using acicular urea particles as space-holder. Mater Lett, vol. 65, pp. 3199-3201. 2011.

24 FERRI, O.M.; EBEL, T.; BORMANN, R. Influence of surface quality and porosity on fatigue behaviour of Ti-6Al-4V components processed by MIM. Mat Sci Eng A, vol. 527, pp. 1800-1805, 2010.

25 LI, J.C.; DUNAND, D.C. Mechanical properties of directionally freeze-cast titanium foams. Acta Mater, vol. 59, pp.146-158, 2011.

26 HEINL, P.; MÜLLER, L.; KÖRNER, C.; SINGER, R.F.; MÜLLER, F.A. Cellular Ti-6Al$4 \mathrm{~V}$ structures with interconnected macro porosity for bone implants fabricated by selective electron beam melting. Acta Biomater, vol. 4, pp. 1536-1544, 2008. 
27 WIRIA, F.E.; SHYAN, J.Y.M.; LIM, P.N.; WEN, F.G.C.; YEO, J.F.; CAO, T. Printing of Titanium implant prototype. Materials and Design, vol. 31, pp. S101-S105, 2010.

28 GREGOROVÁ, E.; PABST, W.; BOHACENKO, I. Characterization of different starch types for their application in ceramic processing. J Eur Ceram Soc, vol. 26, pp. 13011309, 2006.

29 MESQUITA, R.M. "Desenvolvimento de cerâmicas porosas a base de Nitreto de Silício" Dissertação de mestrado. Instituto de Pesquisas Energéticas e Nucleares, São Paulo, 2009.

30 LEGEROS, R.Z.; CRAIG, R.G. Strategies to affect bone remodeling: osteointegration. J Bone Miner Res, vol. 8, pp. S583-596, 1993.

31 PORTO, L.C.; LIMA, A.M.F.; SOLDI, V. Propriedades de filmes de gelatina e poli (acrilamida-coácido acrílico) reticulados por hidrocloreto de 1-etil-(3-3- dimetilaminopropil) carbodiimida. 17ํ CBECIMat - Congresso Brasileiro de Engenharia e Ciência dos Materiais, 15 a 19 de Novembro de 2006, Foz do Iguaçu, PR, Brasil.

32 RIBEIRO, C.; GOIA, T.S.; VIOLIN, K.B.; BRESSIANI, J.C.; BRESSIANI, A.H.A. Osseointegration and biocompatibility study of macroporous biphasic calcium phosphate (BCP) ceramics obtained by consolidation using albumin. Adv Sci Tech, vol. 76, pp. 6671, 2010.

33 BLACK, J. Biological performance of materials: fundamentals of biocompatibility. Marcel Dekker, Inc., Second edition, 1992.

34 TEMENOFF, J.S.; MIKOS, A.G. Biomaterials: The Intersection of Biology and Materials Science. Editora Pearson Prentice Hall, $1^{\underline{a}}$ ed., 2008.

35 HENCH, L.L.; POLAK, J.M. Third-Generation Biomedical Materials. Science vol. 295, pp. 1014-1017, 2002.

36 FELLER, C. Atualização na clínica Odontológica. Editora Artes Médicas, São Paulo - SP. 22 edição, 1998.

37 AVERY, J.K. Desenvolvimento e Histologia Bucal. Editora Santos, 3 ed., 2005.

38 WISE, D.L.; TRANTOLO, D.J.; ALTOBELLI, D.E.; YASZEMSKI, M.J.; GRESSER, J.D. Human biomaterials applications. Human press, Totowa, New Jersey, 1996.

39 RATNER, B.D.; HOFFMAN, A.S.; SCHOEN, F.J.; LEMONS, L.E. Biomaterials Science an introduction to materials in medicine. Academic Press, 1ed., 1996.

40 NIINOMI, M. Recent research and development in titanium alloys for biomedical applications and healthcare goods. Sci Technol Adv Mat, vol. 4, pp. 445-454, 2003. 
41 VAQUILA, I.; VERGARA, L.I.; PASSEGGI, M.C.G.; VIDAL, R.A.; FERRÓN, J. Chemical reactions at surfaces: titanium oxidation. Surf Coat Tech, vol.122, pp. 67-71, 1999.

42 CALLISTER, W.D.Jr. Ciência e Engenharia de materiais: uma introdução. Editora LTC, Rio de Janeiro - RJ. 5ª edição. 2002.

43 BORGIOLI, F.; GALVANETTO, E.; GALLIANO, F.P.; BACCI, T. Air treatment of pure titanium by furnace and glow-discharge processes. Surf Coat Tech, vol. 141, pp. 103107, 2001.

44 TAYLOR, L. Metals Handbook, Properties and Selection of Metals. ASM, Ohio, 1961.

45 GEMELLI, E.; CAMARGO, N.H.A. Oxidation kinetics of commercially pure titanium. Revista Matéria, vol. 12, n. 3, pp. 525-31, 2007.

46 OSHIDA, Y. Bioscience and Bioengineering of Titanium Materials, Editora Elsevier Science, $1^{\text {a }}$ Edição, 2006.

47 EZUGWU, E.O.; WANG, Z.M. Titanium alloys and their machinability - a review. $\boldsymbol{J}$ Mater Process Tech, vol. 68, pp. 262-274, 1997.

48 MELLO, G.M.R. Efeito de elementos betagênicos na estabilidade de fases e propriedades de ligas de titânio para implantes ortopédicos. Tese Doutorado. Universidade Estadual de Campinas, Faculdade de Engenharia Mecânica, SP: [s.n.], 2004.

49 GEETHA, M.; MUDALI, U.K.; GOGIA, A.K.; ASOKAMANI, R.; RAJ, B. Influence of microstructure and alloying elements on corrosion behaviour of $\mathrm{Ti}-13 \mathrm{Nb}-13 \mathrm{Zr}$ alloy. Corros Sci, vol. 46, n. 4, pp. 877-892, 2004.

50 BERTHON, G. Aluminium speciation in relation to aluminium bioavailability, metabolism and toxicity. Coordin Chem Rev, vol. 228, pp. 319-341, 2002.

51 MÜLLER, F.A., BOTTINO, M.C., MÜLLER, L., HENRIQUES, V.A.R., LONHBAUER, U., BRESSIANI, A.H.A, BRESSIANI, J.C. In vitro apatite formation on chemically treated (P/M) Ti-13Nb-13Zr. Dental Mater, vol. 24, n. 1, pp. 50-56, 2008.

52 SCHNEIDER, S.G. Obtenção e caracterização da liga Ti-13Nb-13Zr para aplicação como biomaterial. Tese de doutoramento. Instituição de Pesquisa Energéticas e Nucleares, São Paulo, 141 páginas, 2001.

53 LIMA, S.C.N.; SOARES, E.P.; ANDREOLI, M.; CHIBA, R.; SEO, E.S.M. Caracterização da esponja de zircônio metálico. 20 CBECIMat - Congresso Brasileiro de Engenharia e Ciência dos Materiais, 04 a 08 de Novembro de 2012, Joinville, SC, Brasil. 
54 SEEBER, A. Estudo da Sinterização de Titânio Puro em Descarga Elétrica Luminescente em Regime Anormal. Tese de doutorado da UFSC, Florianópolis, 116 paginas, 2008.

55 GERMAN, R. M. Powder metallurgy science. Editora Metal Powder Industries Federation, New Jersey, 2ª edição, 1994.

56 THUMMLER, F; OBERACKER, R. Introduction to Powder Metallurgy. The Institute of Materials. London, 1993, $332 \mathrm{p}$.

57 WEN, C.E.; YAMADA, Y.; SHIMOJIMA, K.; CHINO, Y.; ASAHINA, T.; MABUCHI, M. Processing and mechanical properties of autogenous titanium implant materials. $J$ Mater Sci- Mater M, vol.13, pp. 397-401, 2002.

58 ST-PIERRE, J.P.; GAUTHIER, M.; LEFEBVRE, L.P.; TABRIZIAN, M. Threedimensional growth of differentiating MC3T3-E1 pre-osteoblasts on porous titanium scaffolds. Biomaterials, vol. 26, pp. 7319-7328, 2005.

59 LI, J.P.; LI, S.H.; BLITTERSWIJK, C.A.V.; GROOT, K. A novel porous Ti6Al4V: characterization and cell attachment. J Biomed Mater Res, vol. 73A, pp. 223-233, 2005.

60 BRAGA, N.A.; FERREIRA, N.G. Obtenção de titânio metálico com porosidade controlada por metalurgia do pó. Quim. Nova, vol.30, n. 2, pp. 450 - 457, 2007.

61 PATTANAYAK, D.K.; MATSUSHITA, T.; DOI, K.; TAKADAMA, H.; NAKAMURA, T.; KOKUBO, T. Effects of oxygen content of porous titanium metal on its apatite-forming ability and compressive strength. Mat Sci Eng C, vol. 29, pp.1974-1978, 2009.

62 VASCONCELLOS, L.M.; LEITE, D.O.; NASCIMENTO, F.O.; VASCONCELLOS, L.G.; GRAÇA, M.L.; CARVALHO, Y.R.; CAIRO, C.A. Porous titanium for biomedical applications: An experimental study on rabbits. Med Oral Patol Oral Cir Bucal, vol. 15, pp. 407-12, 2010.

63 TORRES, Y.; PAVÓN, J.J.; RODRÍGUEZ, J.A. Processing and characterization of porous titanium for implants by using $\mathrm{NaCl}$ as space holder. $\boldsymbol{J}$ Mater Process $\mathbf{T e c h}$, vol. 212, pp. 1061-1069, 2012.

64 AN, Y.B.; OH, N.H.; CHUN, Y.W.; KIM, Y.H.; PARK, J.S.; CHOI, K.O.; EOM, T.G.; BYUN, T.H.; KIM, J.Y.; HYUN, C.Y.; KIM, D.K.; BYUN, C.S.; SOK, J.-H.; KWON, J.J.; LEE, W.H. Surface characteristics of porous titanium implants fabricated by environmental electro-discharge sintering of spherical Ti powders in a vacuum atmosphere. Scripta Mater, vol. 53, pp. 905-908, 2005.

65 JO, Y.J.; LEE, C.M.; JANG, H.S.; LEE, N.S.; SUK, J.-H.; LEE, W.H. Mechanical properties of fully porous and porous-surfaced Ti-6Al-4V implants fabricated by electrodischarge-sintering. J Mater Process Tech, vol. 194, pp. 121-125, 2007.

66 CHEN, L-J.; LI, T.; LI, Y-M.; HE, H.; HU, Y-H. Porous titanium implants fabricated by metal injection molding. T Nonferr Metal Soc, vol. 19, pp. 1174-1179, 2009. 
67 FERRI, O.M.; EBEL, T.; BORMANN, R. Influence of surface quality and porosity on fatigue behaviour of Ti-6Al-4V components processed by MIM. Mat Sci Eng A, vol. 527, pp. 1800-1805, 2010.

68 JUNG, H-D.; YOOK, S-W.; KIM, H-E.; KOH. Y-H. Fabrication of titanium scaffolds with porosity and pore size gradients by sequential freeze casting. Mater Lett, vol. 63, pp. 1545-1547, 2009.

69 YOOK, S-W.; KIM, H-E.; KOH. Y-H. Fabrication of porous titanium scaffolds with high compressive strength using camphene-based freeze casting. Mater Lett, vol. 63, pp. 1502-1504, 2009.

70 LI, J.C.; DUNAND, D.C. Mechanical properties of directionally freeze-cast titanium foams. Acta Mater, vol. 59, pp.146-158, 2011.

71 CHEN, Y.J.; FENG, B.; ZHU, Y.P.; WENG, J.; WANG, J.X.; LU, X. Fabrication of porous titanium implants with biomechanical compatibility. Mater Lett, vol. 63, pp. 26592661, 2009.

72 WIRIA, F.E.; SHYAN, J.Y.M.; LIM, P.N.; WEN, F.G.C.; YEO, J.F.; CAO, T. Printing of Titanium implant prototype. Materials and Design, vol. 31, pp. S101-S105, 2010.

73 HEINL, P.; MÜLLER, L.; KÖRNER, C.; SINGER, R.F.; MÜLLER, F.A. Cellular Ti-6Al$4 \mathrm{~V}$ structures with interconnected macro porosity for bone implants fabricated by selective electron beam melting. Acta Biomater, vol. 4, pp. 1536-1544, 2008.

74 HASLAUER, C.M.; SPRINGER, J.C.; HARRYSSON, O.L.A.; LOBOA, E.G.; MONTEIRO-RIVIERE, N.A.; MARCELLIN-LITTLE. D.J. In vitro biocompatibility of titanium alloy discs made using direct metal fabrication. Med Eng Phys, vol. 32-6, pp. 645-652, 2010.

75 GREGOROVÁ, E.; PABST, W.; BOHACENKO, I. Characterization of different starch types for their application in ceramic processing. J Euro Ceram Soc, vol. 26, pp. 13011309, 2006.

76 RUBIRA, A.F.; MUNIZ, E.C.; GUILHERME, M.R.; PAULINO, A.T.; TAMBOURGI, E.B. Morfologia de hidrogéis-ipn termo-sensíveis e ph-responsivos para aplicação como biomaterial na cultura de células. Polímeros, vol.19, pp. 105-110, 2009.

77 KUMAR, V.; FAUSTO, N.; ABBAS, A. Robbins \& Cotran Pathologic Basis of Disease. Editora Saunders, $7^{\stackrel{a}{ }}$ ed, 2004.

78 KÖNING JUNIOR, B. Implantologia e Osteointegração - Quanto à Pesquisa em Cerâmicas, Aplicações Clínicas e Outros Materiais. 1ª Ed. Roca, São Paulo, 2010.

79 FROSCH, K. -H.; SONDERGELD, I.; DRESING, K.; RUDY, T.; LOHMANN, C. H.; RABBA, J.; SCHILD, D.; BREME, J.; STUERMER, K. M. Autologous osteoblasts enhance osseointegration of porous titanium implants. J Orthop Res, vol. 21, pp. 213-223, 2003. 
80 ROBERTSON, I.M.; SCHAFFER, G.B. Design of Ti alloy for efficient sintering to low porosity. Powder Metall., vol. 52, pp. 311-315, 2009.

81 ASTM C20-00. Standard test methods for apparent porosity, water absorption, apparent specific gravity, and bulk density of burned refractory brick and shapes by boiling water.

82 NTERNATIONAL STANDARD ISO 10993- 5. Biological evaluation of medical devicesPart 5: Tests for in vitro cytotoxicity. Geneva: International Organization for Standardization, 2009.

83 ENDO, N.; SAITOH, H.; MACHIDA, A.; KATAYAMA, Y.; AOKI, K. Phase diagram and equation of state of $\mathrm{TiH}_{2}$ at high pressures and high temperatures. $\boldsymbol{J}$ Alloys and Compounds, vol. 546, pp. 270-274, 2013.

84 ROSA, A.L.; BELOTI, M.M. Effect of cpTi surface roughness on human bone marrow cell attachment, proliferation, and differentiation. Braz Dent J, vol. 14(1), pp. 16-21, 2003.

85 MANSOURIGHASRI, A.; MUHAMAD, N.; SULONG. A.B. Processing titanium foams using tapioca starch as a space holder. J Mater Process Tech, vol. 212, pp. 83- 89, 2012.

86 BANSIDDHI, A., DUNAND, D.C. Shape-memory NiTi foams produced by solidstate replication with NaF. Intermetallics, vol. 15, pp. 1612-1622, 2007.

87 BANSIDDHI, A., DUNAND, D.C. Shape-memory NiTi foams produced by replication of $\mathrm{NaCl}$ space-holders. Acta Biomater, vol. 4, pp. 1996-2007, 2008.

88 ESEN, Z.; BOR, S. Processing of titanium foams using magnesium spacer particles Scripta Mater, vol. 56, pp. 341-344, 2007.

89 WENJUAN, N.; CHENGUANG, B., GUIBAO, Q., QIANG, W. Processing and properties of porous titanium using space holder technique. Mat Sci Eng, vol. 506, pp. 148-151, 2009.

90 XIANG, C.; ZHANG, Y.; LI, Z.; ZHANG, H.; HUANG, Y.; TANG, H. Preparation and compressive behavior of porous titanium prepared by space holder sintering process. Procedia Engineering, vol. 27, pp. 768-774, 2012.

91 CHAPPARD, D.; BASLÉ, M.-F.; LEGRAND, E.; AUDRAN, M. Trabecular bone microarchitecture: A review, Morphologie, vol. 92, pp. 162-170, 2008.

92 GIARDINO, R.; ALDINI, N.N. Integrated Biomaterials Science. Editora Spring Street, New York, NY, 2002.

93 OKAZAKI, Y.; GOTOH, E. Comparison of metal release from various metallic biomaterials in vitro. Biomaterials, vol. 26, pp. 11-21, 2005. 
94 CREMASCO, A.; MESSIAS, A.D.; ESPOSITO, A.R.; DUEK, E.A.R.; CARAM, R. Effects of alloying elements on cytotoxicity response of titanium alloys. Mat Sci Eng C, vol. 31, pp. 833-839, 2011.

95 EISENBARTH, E.; VELTEN, D.; MULLER, M.; THULL, R.; BREME, J. Biocompatibility of beta-stabilizing elements of titanium alloys. Biomaterials, vol.25, n. 26, pp.5705-5713, 2004.

96 VON RECUM, A.F. Handbook of Biomaterials Evaluation. 2 ed. Editora Taylor \& Francis, Philadelphia, EUA, 1999.

97 PEARCE, A.I.; RICHARDS, R.G.; MILZ, S.; SHENEIDER, E.; PEARCE, S.G. Animal models for implant biomaterial research in bone: a review. European Cells and Materials, vol. 13, pp. 1-10, 2007.

98 MISCH, C.E. Implantes Dentários Contemporâneos. Editora Santos, 2ª edição 2000.

99 CALASANS-MAIA, M.D.; MONTEIRO, M.L.; ÁSCOLI, F.O.; GRANJEIRO, J.M. O coelho como modelo animal para cirurgia experimental. Acta Cir Bras, vol. 24, pp.325328, 2009.

100 CUNHA, A.; RENZ, R.P.; WANTOWSKI, G.; OLIVEIRA, R.B.; BLANDO, E.; HÜBLER, R. A surgical procedure using sheep as an animal model to evaluate osseointegration. Rev. Clín. Pesq. Odontol., vol. 3, pp.59-62, 2007.

101 STADLINGER, B.; HENNIG, M.; ECKELT, U.; KUHLISCH, E.; MAI; R. Comparison of zirconia and titanium implants after a short healing period. A pilot study in minipigs. Int $\boldsymbol{J}$ Oral Maxillofac Surg, vol. 39, pp. 585-592, 2010. 